Márcia Helena Vargas Manfrinato

\title{
PROPOSTA DE ORGANIZAÇÃO CURRICULAR EM CURSO TÉCNICO PROFISSIONALIZANTE: MEIO AMBIENTE E EDUCAÇÃO AMBIENTAL - UM ESTUDO DE CASO.
}

Tese Apresentada à Escola de Engenharia de São Carlos da Universidade de São Paulo, como parte dos requisitos para a obtenção do Título de Doutora em Ciências da Engenharia Ambiental.

Orientador: Prof. Dr. Frederico Fábio Mauad

São Carlos 
Dedico este trabalho ao meu marido, Jaime e aos meus filhos, Eduardo, Felipe e Isabela que com a sua cumplicidade, me impulsionam sempre a buscar os desafios da vida. 


\section{AGRADECIMENTOS}

- A Deus, por estar sempre à frente nas minhas decisões;

- Aos meus pais Lúcia e Valdir, por mais este voto de confiança, por todo apoio e paciência;

- Ao meu orientador pelo profissionalismo e credibilidade;

- Aos professores Gabriela, Solange, Matheus, Valdir que muito contribuíram para a melhoria do meu trabalho, com profissionalismo;

- Aos meus amigos Gerson, Eduardo Canais e Célia, que sempre estiveram presentes na minha vida, me incentivando e me apoiando;

- A minha amiga Ariane, que em especial, me aconselhou, me ajudou nas horas difíceis, me incentivou, me proporcionou a alegria da sua companhia através de momentos de descontração e paciência, que muito me impulsionou a seguir em frente, meu muito obrigada;

- Ao Conselho Nacional de Desenvolvimento Cientifico e Tecnológico - CNPq, pela bolsa de estudos concedida;

- Aos funcionários e colegas do CRHEA, por todo apoio!

- Ao Senac que colaborou para a realização deste trabalho, como parceiro, durante a pesquisa. 


\section{RESUMO}

MANFRINATO, M.H.V. (2006). Proposta de organização curricular em curso técnico profissionalizante: meio ambiente e educação ambiental - um estudo de caso. Tese (Doutorado) - Escola de Engenharia de São Carlos, Universidade de São Paulo, São Carlos, 2006.

Este trabalho nasceu da necessidade de pesquisar sobre a temática ambiental ligada ao ensino técnico profissionalizante, já que este profissional, via de regra não tem oportunidade de aprofundar as reflexões a respeito da temática ambiental nos cursos mencionados. Mesmo assim, ele passa por um curto período de formação e imediatamente se insere no mercado de trabalho. No caso da área de gastronomia, a discussão do tema ambiental se faz emergente já que ela tem uma inter-relação direta com o meio natural. Dessa forma, a presente pesquisa buscou analisar a inserção da educação ambiental como um tema transversal na grade curricular do curso de cozinheiro do SENAC de Águas de São Pedro, e a partir disso propor uma intervenção com os docentes de maneira a despertar, sensibilizar e conscientizá-los da relevância da sua inserção no currículo, propiciando oportunidades de desenvolver práticas referentes ao tema. A análise da inserção do tema ambiental foi feita através da aplicação de questionários com os docentes e discentes envolvidos no processo. A partir dos resultados, elaboramos um programa do curso que serviu como subsídio para que os professores repensassem e re-elaborassem suas práticas pedagógicas frente à referida temática. A questão ambiental era considerada um tema de grande relevância, apesar de pouco abordada porque o que os professores sabiam a respeito do assunto era superficial e restrito. Assim compreendemos que eles passaram a perceber a necessidade de se ter uma visão global e critica das questões ambientais, partindo do senso comum para a construção de novos saberes. Há um hiato entre a formação profissional dos professores e a sua prática cotidiana profissional, desvinculada completamente de temas que afetam diretamente a atuação profissional de cada um deles. Os problemas que afetam o mundo, assim como a crise ambiental, não parece fazer parte da sua realidade. Então, os conhecimentos práticos vivenciados pelos professores devem ser articulados com os teórico-acadêmicos, agregando os setores práticos do hotel-escola que compõem o curso de gastronomia, através da integração dos conteúdos. Os professores foram se sensibilizando e assumindo um compromisso de trabalho no decorrer dos encontros, no que diz respeito à importância de sempre recomeçar o processo educativo, já que o curso conta periodicamente com novos alunos. Antes dos encontros isso não acontecia, pois como eles mesmos mencionaram, havia uma fragmentação de informação quanto aos temas ambientais de forma reducionista. Percebemos durante toda a intervenção que os professores atuaram dinâmicos e interessados, sendo que o curso propiciou uma modificação nas pessoas, abrindo novas possibilidades, novas atitudes e favorecendo a reflexão, a reconstrução de novos saberes, gerando novos conceitos e valores, despertando novas atitudes, comportamentos e finalmente novas aprendizagens e práticas educativas. Há necessidade do envolvimento de um maior número de pessoas não somente da comunidade escolar, mas também dos profissionais que atuam nos setores de atividade prática-operacional e diversos níveis da hierarquia funcional do hotel-escola, para que se tenha um engajamento total de todas as áreas do hotel, não se restringindo ao departamento de alimentos e bebidas.

Palavras-chave: Educação ambiental, Curso técnico profissionalizante, Ambientalização curricular, Gastronomia. 


\section{ABSTRACT}

MANFRINATO, M.H.V. (2006). Curricular organization proposal in a technician professionalizing course: environment and environmental education - a study of case. Thesis (Doctoral) - Escola de Engenharia de São Carlos, Universidade de São Paulo, São Carlos, 2006.

This paper was born from the necessity of researching the environmental theme linked to the professionalising technical teaching, which can't go deeper in the reflections on the environmental theme in the mentioned courses. Even so, the professional goes through a short period of training and is immediately inserted in the job market. In the case of gastronomy, the discussion about the environmental theme is emergent since it has a direct relation with the natural environment. So, the present research tried to analyze the insertion of environmental education as a transverse theme in the curriculum of the cooking course of Senac in Águas de São Pedro, and from this, to propose an intervention along with the professors in order to rise, move and aware them of the relevance of its insertion in the curriculum, offering opportunities to develop practices referred to the theme. The analysis of the insertion of the environmental theme was made through the application of a questionnaire to the professors and the students involved in the process. From the results, we developed a program of the course that served as subsidy for the professors to rethink and reorganize their pedagogical practices front to the referred theme. The environmental question was considered a theme of great relevance, despite of being not much approached because what the professors knew about the subject was superficial and restrict. Then we can comprehend that they started to realize the necessity of having a global and critic view of the environmental question, going from the common sense to the construction of new learnings. There is a gap between the professional formation of the professors and their professional everyday practice, completely set apart from themes that directly affect their professional actuation. The problems that affect the world, such as the environmental crisis, don't seem to be part of their reality. So, the practical knowledge lived by the professors has to be worked out along with the theoretic-academic ones, joining the practical sectors of the hotel-school that composes the gastronomy course, through the integration of contents the professors were moved and assumed job commitment in the going of the meetings, concerning the importance of always restarting the educational process, as the course always has new students. Before the meeting it didn't use to happen, as they mentioned it themselves, there was a fragmentation of information as for the environmental themes in a reductive way. We realized during all the intervention that the professors were dynamic and interested, being that the course offered a changing in the people, opening new possibilities, new attitudes and being favorable to reflection, the rebuilding of new learnings, generating new concepts and values, arousing new attitudes, behaviors and finally new learning and educational practices. There is the necessity of involvement of a bigger number of people not only in the school community, but also of the professionals who act in the operational-practice activity area and diverse levels of the functional hierarchy of the hotel-school, for that there is a total commitment of all the hotel areas, not being restrict to the food and drink department.

Keywords: Environmental education, Professionalizing technical course, Curricular environmentation, Gastronomy. 


\section{LISTA DE ABREVIATURAS}

CAC - Curso de Aspirantes ao Comércio

CBC - Curso Básico de Cozinheiro

CCI - Curso de Cozinheiro Chefe Internacional

CEATEL - Centro de Estudos de Administração Hoteleira

CEE - Conselho Estadual de Educação

CEETEPS - Centro Estadual de Educação Tecnológica "Paula Souza"

CET - Centro de Estudos em Turismo e Hotelaria

CFE - Conselho Federal de Educação

CNE - Conselho Nacional de Educação

DFP - Divisão Formação Profissional

EA - Educação Ambiental

Escolas dos “S” - Sistema S (SENAI, SESC, SENAC, entre outras)

FATEC - Faculdade de Tecnologia

FEBEM - Fundação Social do Bem Estar do Menor

FGV - Fundação Getulio Vargas

FUMEST - Fundo de Apoio às Melhorias das Estâncias

IBGE - Instituto Brasileiro de Geografia e Estatística

INA - Instituto Nacional de Aprendizagem

ISO - Intenational Standard Orgazation

IPT - Instituto de Pesquisas Tecnologicas

LDB - Leis de Diretrizes e Bases

MA - Meio Ambiente

MEC - Ministério de Educação e Cultura

OIT - Organização Internacional do Trabalho

ONU - Organização das Nações Unidas

ONG - Organização Não Governamental

PL - Projeto de Lei

PLANFOR - Plano Nacional de Educação Profissional

PNE- Plano Nacional de Educação 
PRODEC - Programa de Desenvolvimento da Pequena e Média Empresa Comercial PROEP - Plano de Expansão da Educação Profissional

PT - Partido dos Trabalhadores

PUC - Pontifícia Universidade Católica

RAF - Restaurante de Alunos e Funcionários

SEFOR - Secretaria de Formação e Desenvolvimento Profissional

SEMTEC - Secretaria de Educação Média e Tecnológica

SENAC - Serviço Nacional de Aprendizagem Comercial

SENAI - Serviço Nacional de Aprendizagem Industrial

SGA - Sistema de Gestão Ambiental

UFPA - Universidade Federal do Pará

UFPE - Universidade Federal de Pernambuco

UFRN - Universidade Federal do Rio Grande do Norte

UNIBERO - Universidade Ibero Americana

UNICAMP - Universidade Estadual de Campinas

UNIMEP - Universidade Metodista de Piracicaba

UNIVALI - Universidade do Vale do Itajaí

USP - Universidade de São Paulo

VUNESP - Vestibular Unificado do Estado de São Paulo 


\section{LISTA DE FIGURAS}

Figura 1 - Painel elaborado pelos professores sobre a representação de meio ambiente.

Figura 2 - Painel elaborado pelos professores sobre a representação de meio ambiente.

Figura 3 - Construção do conceito de educação ambiental - Áreas

Figura 4 - Construção do conceito de educação ambiental - Depósito de lixo .

Figura 5 - Construção do conceito de educação ambiental - Por do Sol.

Figura 6 - Questionário de investigação da inserção do tema ambiental no curso de gastronomia aplicado aos professores

Figura 7 - Apresentação dos resultados do questionário aplicado aos professores e a coordenação sobre a inserção do tema ambiental no curso de gastronomia 234 Figura 8 - Questionário de investigação da inserção do tema ambiental no curso de gastronomia aplicado aos alunos.

Figura 9 - Workshop desenvolvido junto dos professores do curso de gastronomia .. 235

Figura 10 - Elaboração de painel sobre o conceito de meio ambiente no curso de gastronomia 236

Figura 11 - Apresentação de trabalhos durante o workshop . 236

Figura 12 - Apresentação de trabalhos executados durante o workshop . 237

Figura 13 - Debate sobre os temas de educação ambiental 237

Figura 14 - Coleta de resultados da inserção do tema junto dos alunos no curso de gastronomia 238

Figura 15 - Aula ministrada pelos professores no laboratório de gastronomia...... 238 


\section{LISTA DE TABELAS}

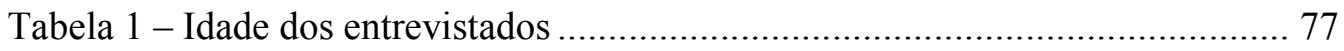

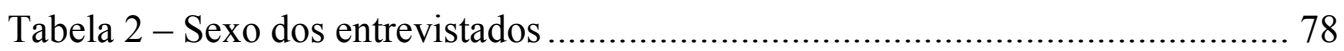

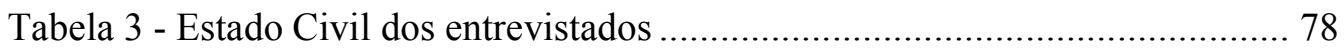

Tabela 4 - Formação Escolar dos entrevistados ................................................... 79

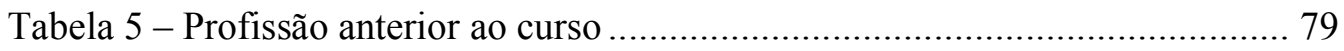

Tabela 6 - Local de Residência dos entrevistados............................................. 80

Tabela 7 - Perspectiva de emprego dentro da área gastronômica ........................ 80

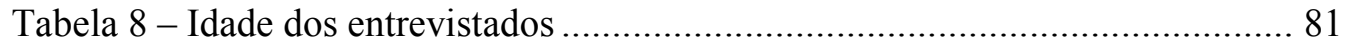

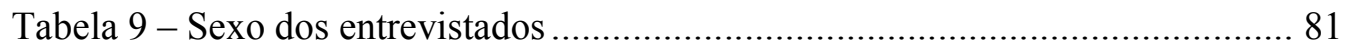

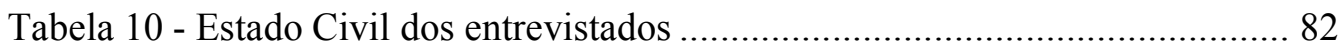

Tabela 11 - Formação Escolar dos entrevistados.................................................. 82

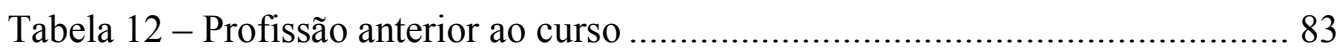

Tabela 13 - Local de Residência dos entrevistados.............................................. 83

Tabela 14 - Perspectiva de emprego dentro da área gastronômica ....................... 84

Tabela 15 - Concepção de meio ambiente ........................................................... 116

Tabela 16 - Concepção de educação ambiental ................................................... 117

Tabela 17 - Concepção de meio ambiente da coordenação e dos professores do

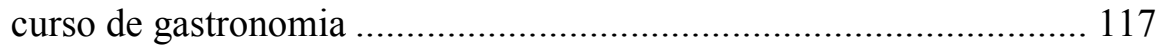

Tabela 18 - Concepção de educação ambiental da coordenação e dos professores

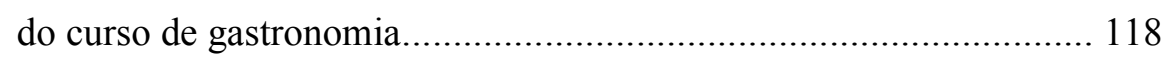

Tabela 19 - Concepção de meio ambiente dos alunos do curso de gastronomia, .... 123

Tabela 20 - Concepção de educação ambiental dos alunos do curso de gastronomia 


\section{SUMÁRIO}

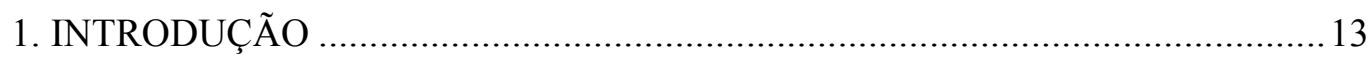

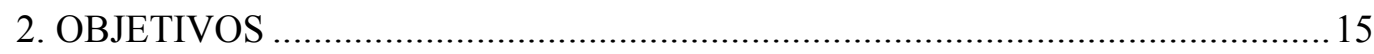

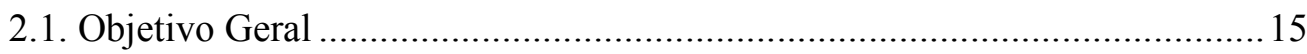

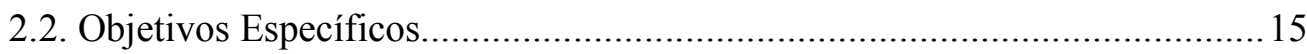

3. A EDUCAÇÃO AMBIENTAL FRENTE À GLOBALIZAÇÃO E À

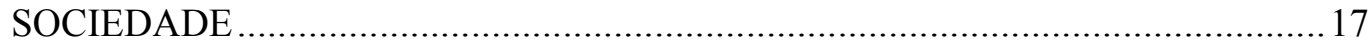

3.1. A educação ambiental o caminho do reencontro de novos valores ................23

3.2. A Inserção da educação ambiental no ensino formal ...................................29

3.3. A educação ambiental como um tema transversal..........................................35

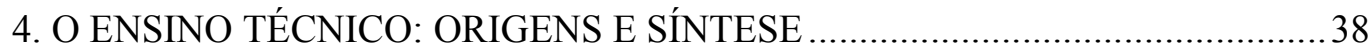

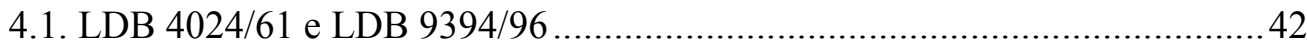

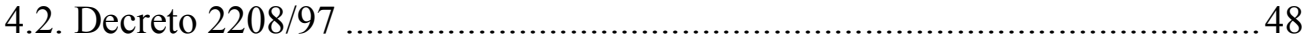

5. A INSTITUIÇÃO SENAC: PARCEIRA NA PESQUISA E INTERVENÇÃO......53

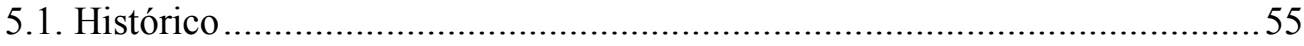

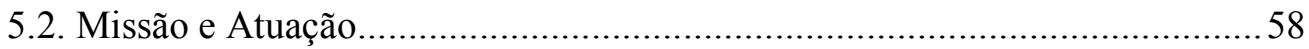

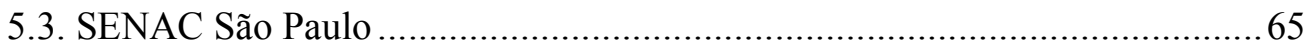

5.4. Grande Hotel São Pedro e Hotel Escola Senac de Águas de São Pedro ........ 70

5.5. O Município de Águas de São Pedro........................................................... 70

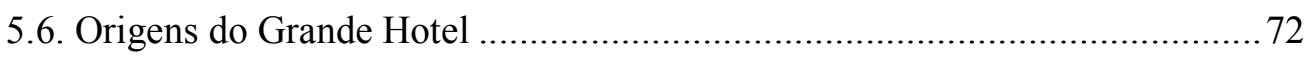

5.7. Corpo discente: composição e perfil....................................................... 74

5.7.1. Características atuais do corpo discente e do corpo docente do

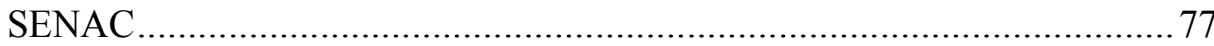

5.7.1.1. Perfil do Corpo Docente do Curso de Cozinheiro ................77

5.7.1.2. Perfil do Corpo Discente do Curso de Cozinheiro ...............81

6. A IMPORTÂNCIA DA INSERÇÃO DA EDUCAÇÃO AMBIENTAL NO

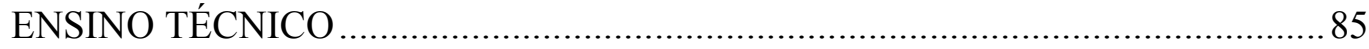




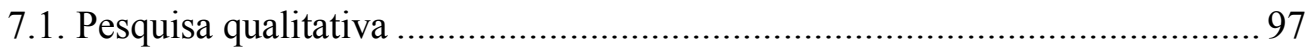

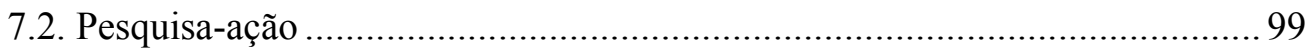

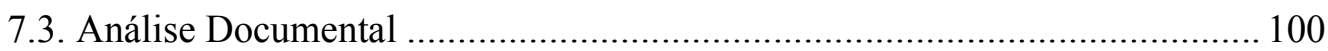

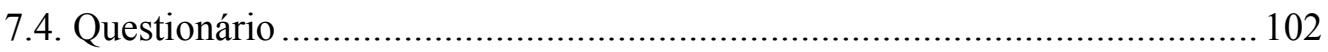

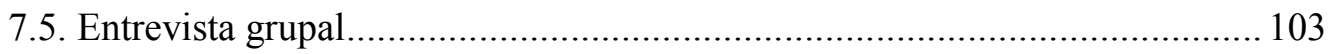

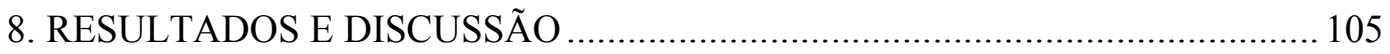

8.1. Análise do tema ambiental na grade curricular do curso de cozinheiro ........ 105

8.2. Análise do tema ambiental nas práticas pedagógicas do curso de

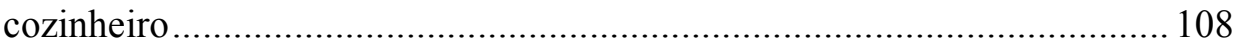

8.2.1. Meio Ambiente na Cozinha: concepções da coordenação e dos professores da área gastronômica ................................................ 108

8.2.2. Concepções dos alunos sobre a inserção do tema ambiental na área gastronômica ................................................................. 118

8.3. Intervenção: a formação ambiental dos docentes dentro do universo

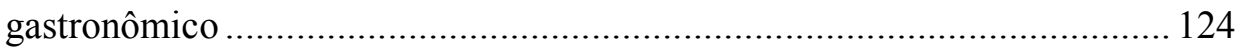

8.3.1. Reflexão e construção do conceito de meio ambiente pelos

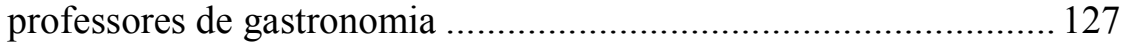

8.3.2. A Construção do Conceito de educação ambiental pelos docentes do curso de gastronomia..

8.3.3. A questão ambiental e o profissional da gastronomia - o uso de

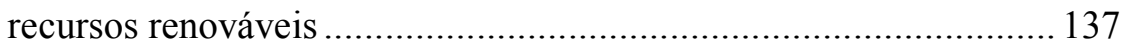

8.3.4. Desperdício, reaproveitamento, lixo e reciclagem na cozinha ........... 143

8.3.5. Consumo responsável............................................................... 148

8.3.6. Educação ambiental: Perspectiva de Racionamento ou

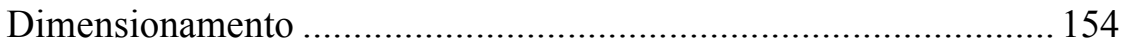

8.3.7. Racionalidade no uso de embalagens: respeito ao meio ambiente ..... 155

8.3.8. Valores da Educação ambiental..................................................... 155

8.3.9. Novas posturas nas práticas profissionais ....................................... 156

8.3.10. Iniciativa de educação ambiental no SENAC.................................. 157

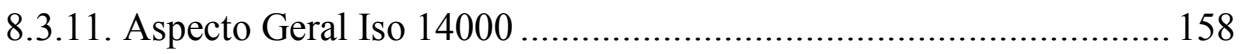

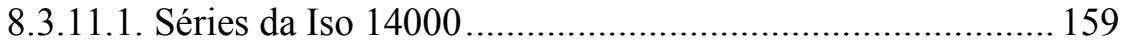

8.4. Avaliação da formação ambiental - com os professores e com os alunos ..... 160 
8.4.1. Reformulação dos planos de ensino pelos professores 160

8.4.2. Avaliação do curso pelos professores ............................................... 168

8.4.3. Avaliação dos efeitos do curso com os alunos ................................. 175

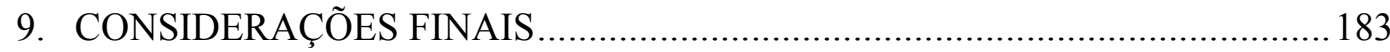

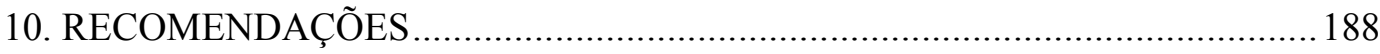

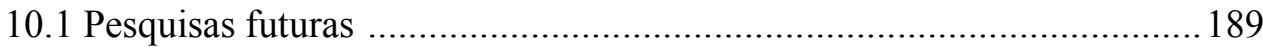

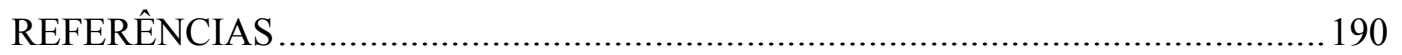

APÊNDICE A - Formulário de levantamento do perfil do corpo docente do curso

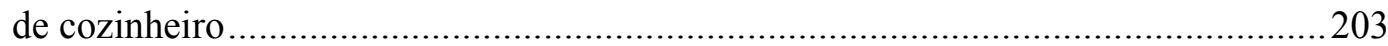

APÊNDICE B - Formulário de levantamento do perfil do corpo discente do curso

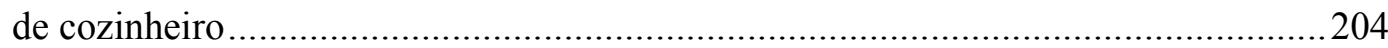

APÊNDICE C - Questionário aplicado à coordenação para investigar a inserção do tema ambiental no curso de gastronomia.......................................................205 APÊNDICE D - Questionário aplicado aos professores para investigar a inserção

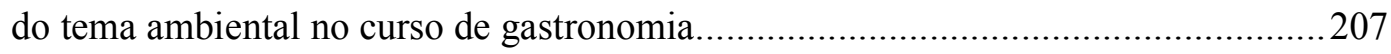
APÊNDICE E - Questionário aplicado aos alunos para investigar a inserção do tema ambiental no curso de gastronomia ...........................................................209 APÊNDICE F - Programação do Curso de Formação dos Professores.......................221 APÊNDICE G - Roteiro de questões de avaliação final com os professores .............212 APÊNDICE H - Questionário de avaliação do curso aplicado aos professores .........213 APÊNDICE I - Questionário de avaliação final aplicado aos alunos do Curso de Cozinheiro

ANEXO A - Grade Curricular do Curso De Cozinheiro - Senac Águas De São

Pedro .216

ANEXO B - Planos de Ensino Reformulados...................................................217

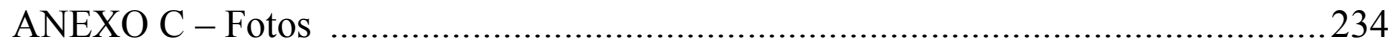





\section{INTRODUÇÃO}

Este trabalho nasceu da necessidade de pesquisar sobre a temática ambiental ligada aos diversos segmentos sociais. A complexidade sócio-ambiental envolve diferentes áreas de conhecimento, tais como a biosfera, a tecnosfera e a psicosfera que fazem interface às distintas áreas que exigem certa habilidade do profissional ao aplicar a teoria à prática profissional, seja em segmentos de atuação profissional operacional ou em segmentos de gestão, a dificuldade se apresenta no dia-a-dia, através de mudanças de hábitos e busca de atitudes concretas que promovam o meio ambiente como parte do ser humano.

Para alguns a educação ambiental esta associada às áreas verdes ou ambientes naturais, ou ainda a atividades que são desenvolvidas em áreas livres, entretanto a educação ambiental deve estar presente nas nossas atitudes e condutas buscando uma efetiva mudança de comportamento e associando essa prática ao desenvolvimento das atividades desenvolvidas em escolas seja em programas de nível fundamental, nível médio, nível profissionalizante ou superior.

Visando uma mudança de comportamento e buscando refletir sobre as atitudes e condutas dos profissionais de gastronomia frente ao meio natural, buscamos desenvolver junto dos professores do ensino técnico uma reestruturação do plano no ensino das disciplinas que norteiam a grade curricular do curso técnico em gastronomia.

Buscamos uma reflexão a respeito da prática profissional dos professores e mudança de atitude frente à educação ambiental, objetivando despertar no aluno e futuro profissional que atuará no mercado de trabalho, valores, atitudes e condutas reflexivas de forma que propiciem a adoção de novas atitudes e novas condutas dentro da sua atuação profisssional.

Os processos de degradação da natureza, a fragilidade dos ecossistemas, os resíduos tóxicos, lixo, perda da biodiversidade e diversos tipos de poluição são 
preocupações que devem estar presentes em sala-de-aula e, principalmente, inseridas nos planos de trabalho dos professores, buscando uma sensibilização junto ao aluno/aprendiz, uma vez que este é um assunto afeta todos os níveis da sociedade.

A escola deve atuar como uma grande aliada desse processo, uma vez que é o lugar mais adequado para iniciar e fomentar a formação de cidadãos na temática ambiental.

Na sua nobre missão de desenvolver conhecimento, a escola deve proporcionar espaço para troca de idéias, debate, novas propostas, que objetive desenvolver nos estudantes uma nova visão de forma que esta o integre ao seu meio.

O aumento da capacidade do ser humano de intervir na natureza para suprir as suas necessidades de desejos ocasiona tensões e conflitos quanto ao uso do espaço e dos recursos.

Então, buscando reduzir a degradação ambiental nos anos 90 as comunidades começaram a se mobilizar objetivando minimizar os efeitos das ações e conseqüências para com o meio ambiente, buscando o comprometimento da população em geral. 


\section{OBJETIVOS}

\subsection{OBJETIVO GERAL}

- Analisar a inserção da educação ambiental como um tema transversal na grade curricular do ensino técnico profissionalizante do curso de cozinheiro do SENAC de Águas de São Pedro;

- Propor uma intervenção com os docentes do curso acima mencionado, de maneira a despertar, sensibilizar e conscientizá-los da relevância da inserção do tema ambiental como tema transversal no currículo, propiciando oportunidades de desenvolver práticas referentes ao tema;

- Apoiar os docentes na reestruturação dos planos de ensino das disciplinas do curso, com a inserção de questões referentes a educação ambiental e o meio ambiente no curso técnico-profissionalizante.

\subsection{OBJETIVOS ESPECÍFICOS}

- Analisar a inserção do tema ambiental na grade curricular e nos planos de ensino do curso técnico profissionalizante de cozinheiro do SENAC de Águas de São Pedro;

- Considerar a inserção do tema ambiental nas práticas do referido curso, bem como a concepção e a importância do presente tema junto dos alunos e professores;

- Planejar uma intervenção educativa com os docentes do mencionado curso técnico que vise incluir o tema ambiental nas reflexões e práticas pedagógicas do curso; 
- Avaliar a efetividade da incorporação da reflexão e das práticas relacionadas ao tema ambiental no currículo do curso junto aos discentes;

- Reestruturação junto com os professores, dos planos de ensino das disciplinas do curso técnico de gastronomia, objetivando o meio ambiente dentro do curso técnico-profissionalizante. 


\section{A EDUCAÇÃo AMBIENTAL FRENTE À GLOBALIZAÇÃo E À SOCIEDADE}

Na década de 70 as questões ambientais passaram a ter relevância, uma vez que houve uma grande diversidade de manifestações através de mobilizações cada vez mais freqüentes e democráticas dos povos, que objetivavam conquistar os seus direitos, a sua liberdade, quanto ao trabalho, à educação, à saúde, etc. (PRATES, 2003).

$\mathrm{Na}$ mesma década surgiu a relevância de projetos que tivessem características de lucro rápido com a eficácia de utilizar o menor tempo possível, oportunizando assim a implantação de indústrias que violentamente se apropriavam dos recursos naturais e humanos (MEDINA, 1997).

Percebemos nas idéias de MEDINA a necessidade de rápida formação de mãode-obra especializada, com o objetivo de atender a demanda do mercado de trabalho, onde surge, como veremos a seguir, a formação de profissionais técnicos para atuarem e atenderem a demanda crescente de indústrias, que por sua vez, acabam se apropriando cada vez mais dos espaços naturais, a fim de atenderem a crescente demanda mercadológica industrial, com a construção civil de grandes instalações em áreas de recursos naturais, gerando poluentes através da produção industrial, seja nos rios ou no ar.

Segundo alguns autores, a crise ambiental é o resultado do crescimento econômico, e se manifesta com a destruição ecológica e a degradação de grupos. A racionalidade econômica tem adquirido proporções planetárias, havendo a necessidade de restabelecer novos estilos de desenvolvimento e novos padrões de produção e de consumo, de maneira que sejam ecologicamente corretos e economicamente sustentáveis.

Para SATO et. al. (2001), a crise é compreendida como uma escolha para uma decisão, e significa romper com algo para assumir uma nova postura, provocando 
rupturas para ultrapassagem e busca de novas formas. A crise, portanto, possibilita também avanços, a restauração do novo, o caminhar adiante.

Assim, o homem já não é visto como externo ao meio ambiente, e sim como parte dele e, uma vez que faz parte da natureza - já que esta é a sua essência - o reencontro com ela o torna mais completo, propiciando-lhe compor-se de forma inteira e com isso incorporar novas dimensões éticas, morais, psicológicas e emocionais (NASCIMENTO e CAMARGO, 2002).

Conforme menciona LEFF (1997), a crise ambiental é o resultado do crescimento econômico e se manifesta com a destruição ecológica e a degradação de grupos. A racionalidade econômica tem se expandido globalmente, e com isso a necessidade de estabelecer novos padrões de produção e de consumo, de forma a sugerir uma nova maneira de agir, voltada à ações ecologicamente corretas e economicamente sustentáveis.

Os novos padrões de consumo deram origem a um novo tipo de capitalismo. Esse novo capitalismo é gerado pela produtividade e competitividade, resultando em características marcantes tais como a inovação, a geração de conhecimentos e o processamento de informações, determinando a globalização (CAPRA, 2000).

Segundo LEFF (1997), a interferência da globalização está transformando os critérios que orientam a educação ambiental, de maneira que o enfoque econômico interfere diretamente no valor da natureza. Assim, a sociedade se vê incapaz de internalizar o real valor dos recursos ecológicos, tornando a natureza sem relevância e gerando uma desvalorização do conhecimento, além de uma inversão de valores em relação à informação, ao poder econômico e à existência humana.

Para Nascimento e Camargo (2002) há um consenso de que os problemas não estão localizados em apenas alguns pontos, mas sim no global. Assim, é preciso pensar e agir local e globalmente.

As instituições de ensino tentam lutar contra as ideologias política-econômicas, que visam minimizar o valor da educação, transformando a sociedade em um conjunto de pessoas incapazes de agir e contribuir para a transformação do conhecimento, fato que LEFF (1997) atribui a "uma administração contábil da gestão ambiental”.

Dessa forma, a globalização tem gerado um certo desconforto às pessoas que se mobilizam em favor da luta pela igualdade e inclusão social, pela conscientização do uso do ambiente natural, pelo uso de práticas que minimizem o aumento da pobreza e o 
desnível de distribuição de renda, como também pelo acesso a todos os níveis de informação.

Uma maneira de minimizar essa crise é a revisão de ações e de valores de comportamento, através de políticas ambientais que interfiram diretamente na sensibilização e intervenção da sociedade, de forma que estas estabeleçam um ciclo entre a sociedade, a dimensão ambiental, o sistema educativo e a formação de recursos humanos de modo crítico e participativo em todas as camadas sociais (LEFF, 1997).

Segundo Capra (2000), os efeitos sociais e econômicos da globalização têm gerado constantes preocupações no âmbito social e acadêmico, uma vez que ela tem colaborado para o aumento da desigualdade e da exclusão social, para o colapso da democracia, para a deterioração mais rápida e mais extensa do ambiente natural, e também para a pobreza e a alienação cada vez maior da população, destruindo, assim, comunidades locais no mundo inteiro.

A educação ambiental deve propiciar à sociedade a participação e o desenvolvimento de idéias e ideais, atuando como uma forte ferramenta para o crescimento e, principalmente, para a autonomia do pensamento crítico.

O ambiente natural, de uso coletivo, deve ser dividido, socializado, pois se a educação ambiental propicia o desenvolvimento de idéias e a autonomia, num espaço social ela vai além, propiciando também atitudes como solidariedade, democracia e envolvimento coletivo, gerando a evolução da comunidade. A busca do entendimento do meio natural e do homem forma um todo, visto que a ação influencia o meio natural, afetando o homem.

Vários autores buscam reflexões e justificativas acerca da diversidade e complexidade ambiental e, para isso, enfocam a verdadeira função da educação e de questões ambientais. Vêem a educação como instrumento de construção da cidadania ambiental e de uma cultura democrática e participativa (LIMA, 2002).

A intervenção do homem na natureza provoca um reequilíbrio e, conseqüentemente uma nova estrutura, a qual mostra como ela é capaz de absorver o impacto, desenvolvendo um novo sistema, que tende a ser novamente destruído pela ação humana, exigindo do meio natural uma estruturação.

No que diz respeito às interfaces entre a natureza e a relação humana, há discursos bem diferentes, tanto no que tange aos interesses e à visão de mundo, como no que diz respeito à riqueza, poder, etc. 
A pós-modernidade adquiriu, em contrapartida, efeitos perversos em relação a sua ampla diversidade e concentração de recursos sejam estes naturais ou construídos.

A educação ambiental leva à reflexão sobre os direitos básicos de cidadania, como livre expressão, direito à organização, acesso à informação, à educação; além dos direitos civis e políticos (CASTRO e BAETA, 2002), embora nas grandes metrópoles o que se vê é a busca pela dinamização econômica do setor terciário, criando sedes de grandes corporações, redes de informações e bens de consumo sofisticados, o que eleva ainda mais a desigualdade e a exclusão social.

A modernização decorrente da globalização só beneficiou uma parcela muito pequena da população, uma vez que nesse contexto a cidadania vem segundo plano (Loureiro (2002)), incorporando outros valores e significados decorrentes do fato de que habitamos em um planeta fisicamente limitado.

Assim, a globalização é um fenômeno contraditório caracteristicamente moderno; Para LOUREIRO (2002) a expressão do desenvolvimento capitalista que acentua ainda mais as desigualdades, é, em contrapartida, uma forma de tomada de consciência da limitação do planeta em termos naturais.

Os valores naturais não devem ser esquecidos no que diz respeito ao poder econômico, pois vão se transformando em mercadoria, na condição de compra e venda, uma vez que eles vão se perdendo ao longo do tempo e sendo destruídos pelo poder econômico.

As sociedades modernas interferem cada vez mais no meio ambiente assim, estão susceptíveis ao impacto de desastres naturais além das conseqüências não desejadas do desenvolvimento tecnológico.

Situações de extrema desigualdade e exclusão social podem ser observadas na maioria das cidades onde há falta de infra-estrutura básica, transporte público, e onde se nota uma privatização elitista de meios naturais.

A emergência de uma nova ética universal é enfatizada e requer um respeito a todas as formas de vida. Os temas principais tais como: solidariedade, liberdade e transformação social; questionamentos como o de dominação-econômica e os modelos de desenvolvimento, devem ser deixados de lado, dando lugar a uma sociedade harmoniosa e responsável (EARTH COUNCIL, 1993 citado por SAUVÉ, 1997). 
A participação da comunidade local é uma forma de manifestação pessoal e engajamento da sociedade, na consciência pela preservação dos meios naturais e do exercício de cidadania.

A educação ambiental deve estar à frente dos problemas que tocam as populações, através de uma inter-relação com a ética, a política, a economia, a ecologia. Assim, CASCINO (1999), define que a:

Educação Ambiental deve ter características, tais como a de permitir que o ser humano compreenda a natureza complexa do meio ambiente, resultantes dos seus aspectos biológicos, físicos, sociais $e$ culturais. Ela deveria facilitar os meios de interpretação da interdependência, a fim de promover uma utilização mais reflexiva e prudente dos recursos naturais para satisfazer as necessidades da humanidade.

Conforme reforça TYLER, GUERRIER e ROBERTSON (2001):

A comunidade local, por meio de representantes eleitos, deve concordar e apropriar-se de seu próprio plano de desenvolvimento, que requer uma discriminação clara das necessidades que pretende satisfazer, quando, onde e como fará e quem vai coordenar, promover, monitorar e avaliar as ações propostas.

Segundo SORRENTINO (2002), a inclusão social, a participação na tomada de decisões e a promoção de mudanças culturais nos padrões de felicidade e desenvolvimento devem fazer parte da proposta de desenvolvimento equilibrado na busca de melhoria de qualidade de vida.

A melhoria da qualidade de vida valida a perspectiva de sustentabilidade ecológica e a educação ambiental dentro desse processo, o qual permite que o grupo social compreenda as relações de interdisciplinaridade com a unidade da paisagem ou do ambiente de entorno, atendendo a diversidade das dinâmicas naturais, sociais e culturais em termos local ou regional (SANTOS e SATO, 2003).

Conforme definiu Bertrand e Valois (1992 citado por SAUVÉ, 1997), citado por SAUVÉ (1997), existem tipos de paradigmas educacionais, que consistem no fato de que os autores reforçam a relação entre os paradigmas educativos e sócio-culturais a 
partir de três visões da educação, utilizando os seguintes exemplos e práticas da educação ambiental:

- paradigma educativo racional: caracteriza-se pela importância aos bens de produção, produtividade, crescimento e competitividade, em que a relação de sociedade com a natureza é a de dominação. A abordagem educacional propõe a transmissão do conhecimento pré-determinado pelo professor numa relação hierárquica, que requer que o estudante reproduza tais conhecimentos;

- paradigma educativo humanístico: relaciona-se ao sócio-cultural existencialista, com ênfase pessoal e de acordo com o potencial e desejos individuais. A relação com a natureza é de respeito e harmonia, em que a educação centraliza-se no educando e no processo de aprendizagem, além de levar em conta a subjetividade;

- paradigma educativo inventivo: refere-se ao paradigma simbiossinergético sócio-cultural, em que há centralização da relação simbiótica entre os seres humanos, a sociedade e a natureza. Essa visão requer uma nova prática educativa, como permitir a escola mais aberta ao mundo real, ao aprendizado cooperativo, à resolução de problemas concretos, dentre outros.

Segundo MÉO (1991), além do papel que o ser humano desempenha na sociedade, existe uma relação direta entre o homem e o espaço natural. Entretanto essa relação com o meio ambiente não é desvinculada da relação com as pessoas e nem com o local; assim o espaço, seja natural ou construído, é particular para cada pessoa, uma vez que é uma relação atrelada ao sentimento, tornando-se uma representatividade individual para cada ser humano.

Ainda segundo o mesmo autor os lugares se constituem em espaços, sejam eles naturais ou construídos, mas que estão imersos em questões e associações vinculadas à sociedade. Dessa forma, um lugar é representativo de acordo com a relação sociedade espaço natural ou construído.

Para ALAMO (1992), faz-se necessário e urgente o desenvolvimento de programas de caráter educativo que provoquem atitudes de domínio em nossa atual sociedade, na transmissão de um novo estilo de vida individual e coletivo, mais integrado e de respeito com o meio natural. 


\subsection{Educação ambiental: o caminho do reencontro de novos valores}

Quando pensamos em educação ambiental buscamos compreender como surgiu, o que é e qual a sua finalidade. A preocupação com a questão ambiental surgiu do conflito entre a sociedade e a natureza, de maneira que potencializou a emergente ação contra a crise ambiental que se instalou no planeta.

Se imaginarmos que não existe um consenso sobre o meio ambiente na comunidade científica segundo REIGOTA (2001), supõe-se que não exista também fora dela, uma vez que cada pessoa possui a sua representação social sobre meio ambiente.

O sentido mais amplo da educação ambiental busca uma mudança fundamental da nossa atitude em relação à natureza: deixar de pensar no que podemos extrair da natureza e começar a pensar no que podemos aprender com ela (CAPRA, 2002).

Segundo SAUVÉ (1997), o discurso e a prática da educação ambiental identificam seis concepções paradigmáticas sobre o ambiente:

- ambiente como a natureza para ser apreciada, respeitada e preservada. Esse ambiente deve ser originalmente puro, do qual os seres humanos estão dissociados e no qual devem aprender a se relacionar para enriquecer a qualidade de "ser";

- ambiente como um recurso para ser gerenciado. Essa é a nossa coletiva herança biofísica, que sustenta a qualidade de nossa vida. Esse limitado recurso é deteriorado e degradado;

- ambiente como um problema para ser resolvido. O ser humano precisa conceber o ambiente enquanto parte dele, aprendendo a apreciar e desenvolver o senso de pertencer a ele. Assim, é necessário que aprenda como identificar, analisar e diagnosticar um problema; como pesquisar e avaliar diferentes soluções; como conceituar e executar um plano de ação; como avaliar os processos e assegurar a constante retroalimentação, enfim, considerar o ambiente como um lugar para se viver, conhecer, aprender, planejar e cuidar;

- ambiente como biosfera, onde viveremos juntos, no futuro;

- ambiente como projeto comunitário, ou seja, um processo no qual todos estejam envolvidos. Esse item contempla o ambiente enquanto coletividade humana, o lugar dividido, o lugar político, o centro da análise crítica, onde predomina a solidariedade, a democracia, o envolvimento individual e coletivo para a participação e a evolução da comunidade. 
Considerando que constantemente precisamos revisar as nossas concepções de mundo, valores, representações sociais, que compartilhamos com as pessoas, e aquilo que os professores ensinam aos seus alunos com relação ao cotidiano de cada um estabelecendo conexões com as questões ambientais e que precisam ser repensadas juntos dos discentes, levando-os a reflexão objetivando a reconstrução de valores dentro do papel que cada um desempenha seja como educador, cidadão, pais, dentre outros papéis (RUSCHEINSKY, 2004).

A idéia de educação ambiental necessita estar pautada em princípios que definam claramente a diferença entre as necessidades reais e os desejos, a redução de dependência e o aumento da autonomia, o favorecimento de recursos renováveis, a utilização dos recursos locais, a reestruturação da economia local, o favorecimento das condições sociais para o fortalecimento das sociedades e a promoção da participação e da solidariedade (ORR, 1992 citado por SAUVÉ, 1997).

GUIMARÃES (2004) chama a atenção sobre o cuidado quanto à educação ambiental conservadora, uma vez que ela busca refletir os paradigmas da sociedade moderna, criando, assim, algumas ciladas e vícios que podem privilegiar alguns aspectos a outros, tais como:

- O educador pode acreditar que transmitir conhecimento correto assegurará que isso irá transformar o comportamento do aluno enquanto indivíduo, ou o comportamento da sociedade;

- $\quad$ A racionalidade sobre o sentimento irá sobrepor a teoria à prática;

- $\quad \mathrm{O}$ conhecimento desassociado à realidade pode resultar em ações de mudança de comportamento;

- $\quad$ O individualismo diante do coletivo;

- $\quad$ O local descontextualizado do global;

- $\quad$ A dimensão tecnicista frente à política.

A educação pode interferir no processo de reconstrução social de uma realidade de maneira a transformá-la, ou pode também atuar como ferramenta - em especial a ambiental, de modo que esta sirva como um mecanismo de gestão e mudança de uma realidade.

Segundo PEREZ (2003) a educação ambiental não se trata de uma tarefa inocente, isenta de intenções e de propósitos. Tata-se de explicitar os conflitos que estamos vivendo, a fim de fazer uma revisão de valores, culturas contraposição de interesses, de ideologias, pressupostos filosóficos divergentes de éticas díspares e de 
práticas cotidianas muito desiguais e variadas. Esta heterogeneidade não pode ser entendida como um modelo de pensamento simplista estritamente lógico e positivista, que ignore subjetividades, significados, intenções e interesses.

O processo pedagógico pode possibilitar o despertar para a preservação e o cuidado do espaço de vivência, além de colaborar para a transformação de cada ser humano, que pode intervir na atual realidade. Desta forma, a educação reabilita para o desenvolvimento da convivência harmônica com a comunidade (SAUVÉ, 1997).

Ainda segundo a mesma autora, o conceito de educação ambiental sempre foi limitado à proteção dos ambientes naturais, desconsiderando-se as necessidades dos direitos das populações associadas a esses ambientes como parte integral dos ecossistemas. Assim, é necessário revisar a ênfase dada aos aspectos relacionados às realidades contemporâneas econômicas ou ao foco da solidariedade planetária, sempre presentes nos discursos da educação ambiental.

Pensar em educação ambiental é buscar compreender, refletir e tratar o meio ambiente como um bem coletivo, imprescindível à vida e à sua reprodução. $\mathrm{O}$ acesso é um direito universal.

Para NASCIMENTO E CAMARGO (2002), repensar o meio ambiente e apropriar-se da educação ambiental é uma forma de buscar uma mudança. Significa o abandono de valores e idéias arraigados e a sua substituição por novas idéias e novos valores. É precisamente neste ponto em que a nossa sociedade capitalista se encontra atualmente; no ponto em que precisamos trocar velhos paradigmas por novos, que precisamos dar mais valor à natureza.

Segundo GUIMARÃES (2004), a educação ambiental deve ser incorporada à educação, uma vez que os professores necessitam refletir sobre os motivos que justificam a necessidade de inclusão da educação ambiental na prática educativa através da transformação do conhecimento, de valores, de atitudes num lugar tão privilegiado de convívio social, que é a escola.

A educação está presente durante toda a trajetória do ser humano, mas no caso do presente trabalho, a educação ambiental não é um ato isolado, pois se configura como "educação", possibilitando atrelar problemas cotidianos e relacionar a sociedade e a natureza de forma que possam intervir sobre os problemas e conflitos ambientais (CARVALHO, 2004). 
A educação ambiental deve ser um processo contínuo que envolva o individual e o coletivo, com o objetivo de resolver problemas relacionados ao meio ambiente, desenvolvendo nas pessoas a criticidade e a criatividade. Assim, ela deve permitir que os indivíduos pensem por si e objetivar o desenvolvimento ideal da humanidade com ênfase na autonomia e no pensamento crítico (SAUVÉ, 1997).

A educação de massa, a educação elitista, a transmissão de conhecimentos da ciência clássica ou positivista, os métodos modernos e sem reflexões críticas, os meios tecnológicos, dentre outros, segundo REIGOTA (2001), não são compatíveis com a educação ambiental, já que esta deve ser pensada como uma forte ferramenta entre as pessoas com diferentes concepções de mundo - seja em relação ao meio natural ou ao meio construído - com diferentes características de relação social, possibilidade de diferentes produtos culturais, diversas formas de expressar suas idéias, seus conhecimentos e sua cultura.

As práticas de educação ambiental devem engajar-se na luta por valores éticos, estilos de vida e racionalidades que compõem a vida social (CARVALHO, 2004). Para apropriar-se da educação ambiental enquanto práxis de vida se faz necessária à garantia de alguns pressupostos, sejam eles coletivos ou individuais, assim como o acesso ao conhecimento, valores, autonomia intelectual, dentre outros (CASTRO e BAETA, 2002).

A educação ambiental deve propiciar a consolidação da democracia, criar valores que integrem as instituições sociais de forma sustentável (GUIMARÃES, 2004).

Segundo Ossa (1989), citado por Sauvé (1997), a educação ambiental deve estar relacionada à concepção do ambiente como um projeto comunitário, em que a ênfase é colocada em uma educação para o desenvolvimento pessoal e social em relação ao ambiente, muito além do que é colocada em preocupações exclusivamente ecológicas. Assim, o ambiente é percebido como uma competência comunitária para interpretar seus problemas, seus recursos naturais, suas necessidades e suas aspirações.

A educação ambiental no Brasil passou a ganhar força, espaço e projeção social, a partir da década de 90, quando se configurou oficial na Constituição Federal de 1988, Capítulo VI, sobre meio ambiente, no seu artigo 225, parágrafo 1, no inciso VI, onde está explicito que compete ao poder público "promover a Educação Ambiental em todos os níveis de ensino e a conscientização pública para a preservação do meio ambiente". 
Segundo CARVALHO (2004) a educação ambiental serve como ferramenta para um possível mundo melhor, na medida em que busca trabalhar os seguintes itens:

- Estabelecer uma reflexão pautada na busca da compreensão dos problemas socioambientais levando-se em conta aspectos geográficos, históricos, biológicos, sociais; além de questões do âmbito subjetivo, tais como aquelas que levem em conta as relações entre o mundo natural e o mundo social, considerando-se os saberes locais, tradicionais e científicos;

- Propiciar a reflexão e ações concretas que possam intervir nos padrões de uso, que estejam pautadas em uma relação sustentável dos bens naturais de forma mais justa e solidária;

- Estabelecer um respeito ecológico frente ao meio ambiente de forma que as pessoas sejam sensibilizadas de forma ética, estética e política, através da identificação de problemas que afetam o ambiente natural em que vivemos;

- Procurar formar pessoas comprometidas com os valores voltados para a construção de uma cidadania ambiental, na qual o processo de ensinoaprendizagem se estabeleça através de trocas, sejam estas formais ou informais;

- Buscar uma inserção cotidiana dentro e fora das escolas, em que as resoluções dos problemas sejam sempre um desafio na busca de articular escola com ambientes locais e regionais onde estão inseridas, ou vice-versa;

- Valorizar experiências vividas anteriormente na busca de compreender as ocorrências e gerar novos conceitos;

- Posicionar o educador como um mediador de relações sócio-educativas, coordenador de ações, pesquisas e reflexões escolares, ou de aspectos relevantes para a comunidade de forma que esta postura sirva como um processo de aprendizado social, individual e institucional, ao qual esteja vinculado.

O objetivo de repensar questões relevantes ao meio ambiente é a busca da racionalidade social produtiva. Essa racionalidade ambiental envolve a reconstrução de conhecimentos, saberes e práticas, a partir da racionalidade formal e instrumental da civilização moderna (LEFF, 1997).

A educação ambiental busca provocar mudanças de atitudes na construção de uma sociedade "ecologicamente correta". Entretanto, não devemos desconsiderar que há necessidade de uma reconstrução de hábitos que desencadeiam atitudes isoladas e que 
são resultantes de comportamentos descontextualizados. Assim, ações isoladas como, por exemplo, a coleta seletiva de lixo, é pouco eficaz porque tendem a permanecer durante um curto período de tempo; depois as pessoas recaem em práticas comportamentais anteriormente adotadas. Segundo Gutiérrez e Prado (1998) citado por Guimarães (2004), educar é impregnar de sentido as práticas da vida cotidiana.

Segundo SAUVÉ (1997), há uma necessidade de uma nova ética universal que deve estar pautada no respeito a todas as formas de vida e que sejam balizadas pela solidariedade, liberdade, transformação social, questionamentos de dominação socioeconômica e por modelos de desenvolvimento impostos.

Assim, a aprendizagem ativa atua de forma dialética em que o aprendiz incorpora novas visões e compreensões críticas de mundo, provendo uma ação transformadora.

Vivemos em uma sociedade pautada no consumismo de recursos, capitais e bens. O consumismo é fruto de uma competição, do individualismo, do egoísmo. (GUIMARÃES, 1995). O exagero do consumismo é resultado de "estar-bem", êxito, desfrutar do ter desmedido, de prosperidade, sucesso e de uma situação de conforto.

A educação ambiental tem por premissa o cunho social e educativo, objetivando a construção de valores e conceitos que se caracterizem através das habilidades e atitudes, e que sejam empregados de formas concretas ou lúdicas; individuais ou coletivas, embasados em uma nova ética da relação sociedade-meio ambiente natural (LOUREIRO, 2002).

Muitos educadores atuam de forma limitada e tradicional ao incluírem a educação ambiental na sua prática pedagógica diária. Dessa forma, a problemática ambientalista é voltada e trabalhada em ações que apontam para a formação de cidadãos que atuem frente ao meio natural, mas que se excluem deste.

Assim, o caminho apontado para o desenvolvimento da prática da educação ambiental deve estar pautado em atitudes que reforcem o processo de construção de uma sociedade justa/eqüitativa que deve rumar para um caminho de interdisciplinaridade, tendo como eixo norteador um novo conceito e novas atitudes de educar fundamentadas em preocupações ambientais.

O saber ambiental incorpora a pluralidade, a diversidade cultural, a formação do conhecimento e a transformação da prática da realidade. A racionalidade ambiental está sustentada por valores sem caráter científico, abrindo espaço para o diálogo entre a ciência e o saber, entre a tradição e a modernidade (LEFF, 1997). 
Não podemos nos esquivar e nos deixar abater, tomando atitudes de desapego, ou ainda sermos escusos do compromisso com os problemas planetários que se colocam à nossa frente, especificamente em relação ao meio natural. Devemos nos envolver nessa "corrente", desde crianças, jovens, profissionais de forma geral e pessoas que estejam na melhor idade. Assim, o compromisso é de uma "ponta à outra", envolvendo o maior número de pessoas, de diferentes grupos sociais, faixas etárias e etnias.

\subsection{A Inserção da Educação Ambiental no ensino formal}

A interdisciplinaridade é entendida como a "interlocução" de disciplinas que reforcem conteúdos disciplinares através do contato em atividades letivas.

A sociedade tem uma forte tendência hegemônica de fragmentar a realidade, minimizando-a em estudos específicos, fragmentando, assim, as áreas do conhecimento, causando um certo isolamento do conhecimento, desconectando a interligação das partes da visão do todo, gerando divisão do trabalho e superespecialização, através da fragmentação do saber (GUIMARÃES, 2004).

As áreas do saber se mantêm compartimentadas pela dificuldade encontrada em estabelecer contato entre uma disciplina e outra, e principalmente pelo fato de existir uma cultura escolar constituída historicamente pela prática isolada de assuntos em comum e vivida pelo ser humano nas suas relações.

Segundo SATO et. al. (2001), o mundo assistiu as fragmentações do conhecimento, as disciplinas isoladas, a desintegração dos saberes e a dinâmica da especialização, retirando da epistemologia a grande tarefa de identificar as interfaces existentes entre os diversos ramos do saber. Todavia, houve um grande avanço do pensamento científico, permeando uma nova visão do universo.

Normalmente os conteúdos que fazem interlocução com as demais disciplinas são tema-chave que integram áreas afins, com o objetivo centralizador da integração disciplinar. Para LEFF (1997) a interdisciplinaridade ambiental não se refere a uma articulação ambiental das ciências existentes, mas a uma colaboração de especialistas de diferentes disciplinas, com a integração de recortes seletivos da realidade para estudo dos sistemas socioambientais, por se tratar de reconstrução de racionalidade social de uma reconstrução ambiental do conhecimento. 
$\mathrm{Na}$ área ambiental, o processo de construção de um conhecimento interdisciplinar propicia aos professores exercerem a função de mediadores nas relações entre as pessoas enquanto sociedade e nas atividades políticas, econômicas, sociais, culturais, e a natureza (GUIMARÃES, 2004).

Embora este enfoque pareça inovador, ele carrega o risco de se trabalhar precariamente no sentido de desenvolver reflexões vazias ou superficiais, trabalhando a análise de conceito-chave sem uma real e profunda reconstrução da idéia de educação.

Segundo MORIN (1997), “a nossa educação nos ensinou a separar e a isolar as coisas. Separamos os objetos de seus contextos, separamos a realidade em disciplinas compartimentadas uma das outras”.

$\mathrm{Na}$ educação ambiental, o educador precisa estar atento a desenvolver uma proposta crítica dentro da perspectiva da interdisciplinaridade, de maneira que esta proposta esteja alinhavada com a proposta das políticas públicas, viabilizando uma articulação entre as diversas áreas do conhecimento, de forma a envolver a prática educativa interdisciplinar enquanto questão ambiental.

O meio ambiente e a interdisciplinaridade buscam tratamentos adequados dentro da educação ambiental e no processo pedagógico, uma vez que a construção de conhecimento é complexa e visa à aproximação da realidade, de maneira que a integralidade de novos conhecimentos é construída através da aglutinação de novos valores e atitudes, resultando em novas práticas sociais.

O saber ambiental extrapola o campo da racionalidade científica e da objetividade do conhecimento. Este saber está inserido em uma nova estratégia conceitual, ele busca uma revitalização do planeta através da revalorização de um conjunto de saberes (LEFF, 1997).

A interdisciplinaridade funciona como uma ferramenta que possibilita que o meio ambiente seja compreendido de forma integral dentro da sua complexidade, através de partes interdependentes e interativas em uma concepção sistêmica (GUIMARÃES, 2004).

Segundo FAZENDA (1992) a interdisciplinaridade pode ser entendida como a possibilidade de diálogos entre partes interessadas, resultando em atitudes concretas, de forma integrada. Assim, a conexão - ou seja, a interlocução - dos diversos assuntos se 
funde na busca da complementação das particularidades e peculiaridades de cada disciplina. Esse diálogo permite constituir a riqueza da diversidade.

A interdisciplinaridade objetiva articular as diversas áreas do conhecimento entre si, através de compartimentos de suas problemáticas e através da diversidade de seus domínios, embora exista a dificuldade cotidiana de inserir as atividades acadêmicas na fragmentação do processo de aprendizagem, seja da ordem epistemológica, seja por conta antropológica. Esta é uma barreira a ser transposta (NOAL, 2003).

A abordagem interdisciplinar dentro do contexto ambiental atua como um enfoque em que visa inserir-se dentro do currículo escolar de forma a colaborar na solução dos problemas ambientais, interagindo de forma transversal.

Segundo NOAL (2003), para alguns autores a interdisciplinaridade se apresenta como sendo:

"O principio da máxima exploração das potencialidades de cada ciência, da compreensão de seus limites, mas, acima de tudo é o principio da diversidade e da criatividade... Interdisciplinaridade instrumental como ciência imperialista, em que a natureza é citada como um bem e não por si só, a teoria atua como uma fase intermediária do processo somente”. (ETGE, 1993 citado por NOAL, 2003).

Para outros, ainda segundo o autor acima destacado, a interdisciplinaridade configura-se como sendo:

$O$ "deslocamento do domínio cognitivo para os domínios sociais, políticos, éticos e até mesmo estéticos". (GUATTARI, 1992 citado por NOAL, 2003).

Segundo SERRANO (2000), a interdisciplinaridade tratada em educação ambiental é chamada de estudo do meio através de experiências que estimulem a sensibilidade e a reflexão e à consolidação do aprendizado formal.

As questões socioambientais configuram-se como multi, inter e transdisciplinares uma vez que interligam questões sociais, ambientais, econômicas, políticas, estéticas e culturais, dentre outras (NOAL, 2003).

A interdisciplinaridade busca uma conexão entre assuntos que, a priori, parecem distantes dentro de qualquer temática; mas em especial na educação ambiental essa prática deve acontecer de forma dinâmica e integrada, buscando a inserção dos 
professores e alunos de maneira participativa, em que cada um possa contribuir com a sua formação e a dos demais membros do grupo, através da troca de experiências, envolvendo as pessoas num processo de construção e de mudanças, na elaboração de propostas pautadas na reflexão e na ação integrada com a realidade ambiental local, de modo a transformá-la.

Para GUIMARÃES (2004), a ruptura do individual configura-se como uma transformação significativa, cuja parte do individual constitui-se na transformação do todo. Assim, o individual e o autônomo tomam novas posturas voltadas para a sinergia, que segundo o autor é o resultado de um movimento conjunto munido de intenção coletiva centrada em objetivos comuns, gerando, então, um produto qualitativamente melhor.

Dessa forma, o conteúdo ministrado em sala-de-aula deve estar relacionado à realidade. Se a transmissão desse conhecimento estiver distante da realidade concreta do dia-a-dia, o professor estará alienando o seu aluno, minimizando o seu conhecimento (GUIMARÃES, 1995). Portanto, o planejamento do professor deve buscar a participação de todos os elementos envolvidos no processo pedagógico, deve integrar a teoria à prática; deve partir de uma realidade concreta que englobe aluno, escola, contexto social, amplitude e criticidade da educação em todos os níveis de conhecimento (LOPES, 1990).

A educação deve ocorrer de forma cíclica, através de ações permanentes através das quais o processo educativo seja uma ação para a transformação de uma realidade vivenciada pelos agentes sociais, em que cada diagnóstico levantado tenha um plano de ação executado pelos professores e alunos e funcione de forma dialética, de retomada constante.

Segundo SATO e SANTOS (2003) a educação ambiental não pode ser transformadora se estiver sozinha. É necessário estabelecer uma rede de diálogos entre as disciplinas, os educadores e o cotidiano para que ela atue como transformadora, viabilizando trabalhos de forma interdisciplinar, resgatando identidades, de forma que o corpo docente atue dentro da especialidade da educação ambiental.

A problemática ambiental é tão extensa que se faz necessária uma medida dentro da realidade cotidiana de cada indivíduo na sociedade. Assim, pode haver mudanças de comportamento através de uma revisão de hábitos do dia-a-dia, e a escola atua como 
articuladora das informações que geram essas mudanças, viabilizando novas condutas e agregando novos valores.

Desde a década de 70 tenta-se uma atitude concreta em busca de resultados e mudanças relativos ao meio ambiente, mas o que se vê são atitudes isoladas, frágeis e sem concretude aparente. Já nos anos 80 os recursos naturais passaram a ser pautados e mencionados com relevância nos fóruns educacionais, onde surgiu à expressão "atitude ecologicamente correta", posteriormente incluída nas disciplinas de caráter de científico e ecológico.

Mas somente na década de 90, na busca por uma objetividade concreta e efetiva com relação às medidas sobre o meio natural, foi que a educação ambiental se sintonizou com as diretrizes ambientais mundiais. Mas ainda hoje ela procura os seus rumos, visto que as diretrizes nacionais ainda buscam a viabilização das resoluções para a problemática que afeta o mundo, objetivando trabalhar propostas com envolvimento de alcance nacional, através de programas e de eventos oficiais ou civis, e que envolvam a população de maneira geral. Segundo TRISTÃO (2004), o papel das instituições de ensino tem um contexto importante de formação ambiental para a construção coletiva de um futuro sustentável.

A educação segundo LIMA (2002), atua "como um instrumento de construção da cidadania ambiental e de uma cultura democrática participativa”.

A educação crítica e voltada para o meio ambiente deve estabelecer conexão com elementos sócio-históricos e políticos na relação aluno/professor, de forma que se estabeleça a construção de um trabalho educativo concreto, relacionado com o cotidiano de uma prática cidadã.

Embora algumas escolas não exerçam a função de atrelar a inserção social, de promover a minimização de desigualdades sociais, o exercício da democracia, a autonomia de reflexão e a busca do conhecimento (parte delas promovem ainda mais a desigualdade de oportunidades), contribuem com as injustiças sociais, não exercem a democracia para todos e, ainda, alienam os aprendizes de forma a não pensarem com autonomia, neutralizando esse processo de aprendizagem e reforçando ideologias dominantes.

Os processos pedagógicos formais e não-formais devem propiciar a sensibilização, aquisição de conhecimento e a mobilização de programas, embora a educação não tenha vida autônoma, se configurando como um subsistema social, que 
depende de um conjunto de fatores para se inserir e assim buscar forças políticas, culturais e filosóficas para definir o futuro.

A educação ambiental vem se difundindo nas escolas enfaticamente. A constante presença do meio ambiente vem refletindo a demanda da sociedade na necessidade e na urgência de desenvolver cada vez mais ações denominadas de educação ambiental, uma vez que esta já é realidade para muitos dos professores, e estes se sentem forçados a se preocupar sobre essa nova temática educativa.

Há urgência em se trabalhar através de uma reflexão sobre as necessidades humanas e pelos valores socialmente construídos da educação formal e informal (SERRANO, 2000).

Porém, em alguns casos (muito presentes) a ação educativa ambiental se apresenta fragilizada na prática pedagógica cotidiana, uma vez que a crise ambiental passa por profundas mudanças e transformações e essas buscam contribuir com esse processo, assumindo um caráter transformador (GUIMARÃES, 2004).

A dimensão ambiental no currículo dos cursos, dentro de uma perspectiva interdisciplinar e da transversalidade, pode resultar na reorientação e rearticulação de conteúdos das diferentes disciplinas que integram um programa no que diz respeito a conhecimentos, habilidades, competências, valores e relações, articulando a construção de uma visão sistêmica da problemática ambiental (GUERRA, 2003).

A rearticulação do desenvolvimento de conteúdos curriculares de educação ambiental precisa buscar um universo diversificado das possíveis propostas desse conteúdo, bem como a concretização de novas propostas que visem a avaliação sobre o tipo de educação ambiental que está sendo feita dentro das escolas, se é ou não compatível com a educação ambiental que queremos (LEME, 2006).

Ainda segundo a mesma autora, a educação ambiental dentro das escolas gera questionamentos, reflexões e ações desencadeadas por este movimento (educação ambiental) que podem, juntamente com outros movimentos, contribuir no estabelecimento de novas relações entre as pessoas, e destas com a sociedade e com a natureza.

Entretanto, os conteúdos dos documentos político-econômicos, legais e educacionais não tratam o assunto com a crítica ou profundidade ambiental que a causa merece. Assim, torna-se constante a redução de espaços democráticos e da participação social, gerando cada vez maior carência social e ampliação das desigualdades. 
A educação ambiental tem passado por constantes avaliações no que diz respeito ao contexto nacional e até mesmo internacional, mas que segundo SATO e SANTOS (2003), a sua configuração inicial era um problema, uma vez que era vista como um único caminho para resolução de todos os dilemas ambientais. A educação ambiental não é uma educação qualquer, nem sequer uma educação específica; é uma identidade que necessita ser constantemente repensada e avaliada (SATO e SANTOS, 2003), uma vez que ela pode cair no modismo, ou parecer estática em um mundo tão dinâmico. Por isso é necessário que ela esteja presente em todas as modalidades de ensino e também nas atitudes, sejam estas isoladas ou conjuntas.

A humanidade evoluiu de maneira que o homem deixou de perceber o domínio que exerce sobre a natureza, de tal forma que se posiciona de maneira autônoma com a mesma, dominando, assim, o meio ambiente e se colocando em uma posição de superioridade, em que o meio ambiente está a serviço do ser humano.

\subsection{A Educação Ambiental como um Tema Transversal}

A inclusão dos temas transversais na grade curricular dos cursos regulares através de uma decisão do MEC objetivou-se o resgate da dignidade da pessoa humana, a igualdade de direitos, a participação ativa na sociedade e a co-responsabilidade pela vida social.

Segundo Araújo (2003) esta inserção do tema transversal no currículo das escolas de forma a trabalhar temas relevantes da nossa educação brasileira, como forma de auxiliar as reflexões das pessoas oportunizando a transformação da escola e da sociedade.

Assim, temas corriqueiros do dia-a-dia devem fazer parte do eixo tradicional da grade curricular dos cursos, de forma que temas vinculados ao cotidiano da sociedade atuem dentro dos currículos tradicionais, compondo o sistema educacional em torno das diversas áreas do conhecimento.

Os temas transversais devem compor o currículo escolar de forma intrínseca, ou seja, o conteúdo do tema transversal a ser abordado deve estar introduzido no conteúdo tradicional.

Os temas transversais devem ser desenvolvidos de forma pontual através de projetos específicos. Assim, em um determinado momento, o professor não se 
restringiria somente ao tema da disciplina em questão, mas agregaria informações de forma enriquecedora, incorporando em sua disciplina o tema transversal em suas aulas.

A prática de vincular os temas transversais aos conteúdos tradicionais favorece a sedimentação da prática interdisciplinar no desenvolvimento de práticas pedagógicas, enriquecendo, assim, a grade do curso, bem como os conteúdos desenvolvidos em sala de aula.

A proposta dessas formas de desenvolvimento dos temas transversais visa conceber a manutenção de disciplinas tradicionais do sistema educacional e propiciar a incorporação de diversos temas, que devem girar em torno do eixo transversal.

Araújo (2003) nos propõe que deixemos de encarar os conteúdos curriculares tradicionais como "fim" mas passemos a observá-los e a praticá-los como "meio" de forma a atuar na construção da cidadania e de uma sociedade mais justa, assim se os conteúdos tradicionais estiverem integrados em um projeto educacional privilegiando a prática de relações interpessoais, sociais e éticas de respeito às outras pessoas, à diversidade e ao meio ambiente.

A conexão dos temas transversais aos conteúdos curriculares dos cursos atua como valores culturais, buscando a aproximação do cientifico ao cotidiano.

O pensamento transforma-se com a aprendizagem, mas isso requer um determinado tempo. A transformação não ocorre sem compreensão e de forma desarticulada do contexto em que se vive, nem se beneficia das mudanças intelectuais que ocorrem nos processos construtivos de novos conhecimentos.

Dessa forma, os temas transversais buscam uma união entre o cotidiano e o acadêmico/científico, de tal forma que possam propiciar instrumentos claros e propor resultados perceptíveis, uma vez que na maioria das vezes as pessoas não sabem utilizar as informações obtidas em sala de aula em situações concretas do dia-a-dia, de tal forma que se estabeleça uma conexão entre o aprendizado da escola e o que acontece diariamente no ambiente externo às instituições de ensino.

A adequação dos objetivos e dos conteúdos de qualquer currículo em um ciclo de ensino deve estar marcada pela reflexão pautada nos objetivos do programa do curso. Assim, deve-se levar em conta o ambiente sociocultural no meio do qual procedem os alunos.

Os temas transversais conduzem tanto alunos como professores a ingressarem em novos conhecimentos, na resolução de problemas e na busca por soluções, ligando a teoria à prática. 
A grade do curso de gastronomia, em especial, tem muita facilidade em aliar a teoria à prática, uma vez que $70 \%$ baseia-se em aulas teóricas desenvolvidas em laboratório, e também porque se trabalha o bem estar das pessoas.

Em 1976, o X Congresso de Médicos e Psicólogos de Língua Catalã matizou a definição sobre o conceito de saúde da seguinte forma: "a saúde do ser humano é aquela maneira de viver autônoma, solidária e prazerosa" ${ }^{1}$ (BUSQUETS e LEAL, 2003).

A busca do equilíbrio entre o prazer, a saúde e a educação na formação profissional, visa formar futuros profissionais voltados para a autonomia, a capacidade de construção de um equilíbrio entre o bem-estar físico, psíquico e social, objetivando desenvolver pessoas capazes de decisões, habilidades e equilíbrio de forma que sejam realizadas profissionalmente e capazes de atuarem diretamente no lazer e bem estar de outros indivíduos.

Segundo os autores BUSQUETS E LEAL (2003) as estratégias de ensinoaprendizagem devem levar em conta as seguintes questões:

- a identificação de quem aprende com a tarefa proposta, graças à proximidade daquilo que é proposto na sua vida cotidiana;

- a facilidade de exteriorização do pensamento, que deve ser propiciada pelo educador, visando à participação ativa de todos os alunos, seja esta de nível intelectual e/ou físico;

- as contribuições de bagagens do passado na fase da infância, adolescência e vida adulta, possibilitando nos processos de ensino-aprendizagem;

- o educador deve levar para sala de aula contradições como agentes mobilizadores das formas de pensar;

- o professor deve contrastar opiniões entre os estudantes de forma a enriquecer e desenvolver o intelecto da classe;

- as informações devem ser necessárias para o avanço no conhecimento que está sendo construído junto ao grupo de alunos;

- o educador deve articular os diversos níveis evolutivos que se manifestam em um grupo social;

- o professor deve estar preocupado em avaliar os resultados de ensinoaprendizagem, sempre integrado a um processo contínuo particular para cada sujeito.

\footnotetext{
${ }^{1}$ Grifo nosso.
} 


\section{O ENSINO TÉCNICO: ORIGENS E SÍNTESE}

O ensino profissionalizante foi concebido como uma modalidade de ensino destinada a camadas mais pobres da população, cujos filhos seriam preparados para as atividades manuais; aqueles que fossem desempenhar uma função intelectual ou instrumental seguiriam uma trajetória educacional em escolas de formação acadêmica. Os trabalhadores com funções de execução teriam uma formação profissional em instituições especializadas que às vezes ocorriam no próprio local de trabalho.

Em 1891 a Constituição da República instituiu a descentralização do ensino, no seu artigo 35, delegando aos Estados a autonomia para prover e legislar sobre a educação primária e o ensino profissionalizante, enquanto que a União ficou responsável pela criação e controle das instituições de nível superior em toda a nação.

Segundo ROMANELLI (1998) era uma forma de oficialização da distância que se mostrava, na prática, entre a educação da classe dominante (escolas secundárias acadêmicas e escolas superiores) e a educação do povo (escola primária e escola profissional).

As escolas que desenvolviam o ensino profissionalizante na maioria se localizavam onde houvesse indústrias. Sua criação atendia à necessidade de o Estado oferecer alternativas de inserção no mercado de trabalho aos jovens oriundos das camadas mais pobres da população. Tinham um caráter eminentemente prático, deixando de lado, nas suas propostas curriculares, as teorias que levassem o indivíduo a uma reflexão, pois o objetivo era apenas formar o jovem carente para atuar no mercado de trabalho como um profissional qualificado.

Segundo Franco (1994)

O ensino profissionalizante no Brasil reporta-se aos idos de 1800, quando os arsenais de guerra existentes desenvolviam- 
no para vários ofícios. Em 1834, o "Arsenal de guerra" do Rio de Janeiro tinha 200 jovens aprendendo os mais diversos oficios. Admitidos entre 8 e 12 anos, aos 21 anos recebiam uma certificação de mestre em alguma especialização.

Surgem, em 1909, as escolas de aprendizes artífices, no governo de Nilo Peçanha, direcionadas para os filhos dos desfavorecidos da fortuna (FRANCO, 1994). Formaram-se, assim, as redes escolares com diferentes objetivos sociais: uma destinada à elite, às classes dirigentes, com valores voltados para o intelecto, visando à formação no ensino superior; uma outra destinada às camadas menos favorecidas, voltadas para os trabalhos manuais, visando à formação no ensino profissionalizante.

Em 1920 a escassez de estabelecimentos oficiais para o ensino secundário propiciou o crescente número de escolas particulares. Surgiu então, a partir da Lei número 1.635 de 31 de dezembro de 1918, a Escola Profissional Masculina de Rio Claro.

Em 1922, Fidelis Reis propôs tornar o ensino profissional obrigatório, indistintamente, para pobres e ricos. A proposta de Reis tramitou pelo Congresso durante cinco anos, chegando a transformar-se em lei, sem que jamais fosse cumprida. ${ }^{2}$ Em 1926, o ensino profissional era mantido à parte, sem nenhuma relação com os outros níveis de ensino. Era de caráter terminal e não dava acesso à Escola Superior. Nesse mesmo período, é criada a Inspetoria de Trabalhos Manuais, que tinha o objetivo de dar assistência sistemática às escolas profissionais, procurando torná-las homogêneas.As novas escolas deveriam seguir os moldes administrativos e didáticos das poucas já existentes.

Em 1929, com a quebra da bolsa de Nova York, o Brasil têm as suas sacas de café $^{3}$ sem comercialização, o que gera uma grande crise na economia do país. A referida crise ocasionou o fortalecimento da produção industrial do país, impulsionando a classe urbano-industrial.

A indústria, por ter-se tornado um setor em crescimento da economia, exigia um sistema de ensino que preparasse o cidadão para o trabalho industrial. Procurou-se,

\footnotetext{
${ }^{2}$ O projeto de Fidelis Reis teve a redação alterada, para excluir sua obrigatoriedade em 1927. Sancionado pelo decreto número 5211, de 22 de agosto de 1922, em redação substitutiva que excluía a questão da obrigatoriedade do ensino profissional. O decreto determina que fariam parte, obrigatoriamente, dos programas das escolas primárias subordinadas ou mantidas pela União, cursos de desenho, trabalhos manuais e rudimentos de artes e ofícios ou industriais.

${ }^{3} \mathrm{O}$ café era o produto principal do Brasil, líder das exportações do produto.
} 
então, um reajustamento dos novos setores da sociedade, tanto interna como externamente, visando o mercado internacional.

Em 1931 Francisco Campos implantou, no ensino secundário, a fiscalização sistemática das escolas e a obrigatoriedade da freqüência regular às aulas. A reforma por ele efetivada tinha como objetivo criar, entre os cursos acadêmicos e técnicos, o ensino médio paralelo, com a reforma do ensino comercial numa perspectiva profissionalizante. Foi também o responsável pela regulamentação, não só do ensino secundário, mas também do superior e do comercial, por meio de uma série de Decretos $^{4}$.

Em 1933, o mercado interno emergiu concomitantemente à queda das exportações, o que implicou em desvio de investimentos do setor agrícola para o setor industrial, provocando visível progresso deste que, beneficiado graças à crise, passou a contar com a disponibilidade do mercado interno, então não mais dominado pelo capital estrangeiro.

Em 1934, foi promulgada a nova Constituição, que retratava a influência do Manifesto dos Pioneiros, que previa o direito a educação para todos, o dever do Estado em disponibilizá-la, a gratuidade e obrigatoriedade do ensino, com o golpe que instalou o Estado Novo, em 1937, houve a promulgação de uma nova Constituição que previa a isenção do dever do Estado com relação à educação, mantendo-se a obrigatoriedade e gratuidade da escola. Quanto ao ensino profissionalizante, oficializou-se a discriminação social, destinando-o às classes menos favorecidas, no seu artigo 129, que tratou das "escolas vocacionais e pré-vocacionais", e que afirmava:

$\grave{A}$ infância e à juventude, a que faltarem os recursos necessários à educação em instituições particulares, é dever da Nação, dos Estados e dos Municípios, assegurar, pela fundação de instituições públicas de ensino em todos os seus graus, a possibilidade de receber uma educação adequada às suas faculdades, aptidões e tendências vocacionais.

\footnotetext{
${ }^{4}$ Os Decretos são os seguintes: decreto número 19.850, de 11 de abril de 1931 - cria o Conselho Nacional de Educação; Decreto número 19.851, de 11 de abril de 1931 - dispõe sobre a organização do ensino superior no Brasil e adota o regime universitário; Decreto número 19.852, de 11 de abril 1931 - dispõe sobre a organização da Universidade do Rio de Janeiro; Decreto número 19.890, de 18 de abril 1931 dispõe sobre a organização do ensino secundário; Decreto número 20.158, de 30 de junho de 1931 organiza o ensino comercial, regulamenta a profissão de contador e dá outras providências; Decreto número 21.241, de 14 de abril de 1932, consolida as disposições sobre a organização do Ensino Secundário (ROMANELLI, 1994).
} 
Em 1942, começou a conhecida Reforma Capanema, com as chamadas "Leis Orgânicas do Ensino". Nesse ano, foi promulgada a Lei Orgânica do ensino secundário (Decreto Lei número 4244/42) e do ensino industrial (Decreto Lei número 4073/42). Nesse conjunto de leis orgânicas, diferenciava-se claramente o objetivo do ensino secundário e normal, e o objetivo do ensino profissional. O primeiro deveria formar as elites condutoras do país e o segundo seria destinado aos filhos de operários que necessitavam ingressar na força de trabalho.

Em 1943, foi expedido o Decreto-Lei número 6.141, chamado de Lei Orgânica do Ensino Comercial, definindo uma estrutura similar à do industrial. A diferença estava no fato de os cursos técnicos, oferecidos nas modalidades de comércio, permitirem, agora, o acesso ao ensino superior, mediante vestibular.

Foi promulgada a Constituição de 1946 que, segundo Romanelli (1994), “um documento de inspiração ideológica liberal-democrática (...)”, os seus princípios “asseguram direitos e garantias individuais inalienáveis (...)”. Era muito parecida com a Constituição de 1934. No mesmo ano de 1946 foi constituída uma comissão de educadores, pelo então Ministro da Educação Clemente Mariani, para propor um projeto de reforma geral da educação nacional.

A referida comissão de educadores responsáveis pelo projeto de reforma geral da educação nacional foi liderada pelo professor Lourenço Filho, que encaminhou o anteprojeto à Câmara Federal no ano de 1948. Houve uma longa luta durante a sua tramitação, sem precedentes históricos, e que resultou posteriormente na Lei de Diretrizes e Bases da Educação Nacional, sob o número 4.024, de 20 de dezembro de 1961.

Em 1961, foi aprovada a Lei de Diretrizes e Bases da Educação Nacional (Lei número 4024/61), definindo a profissionalização e, supostamente, a eliminação da dicotomia entre educação geral (acadêmica) e formação especial (técnica) por meio da abertura de acesso ao vestibular para todos os estudantes. Esta configuração permitia flexibilidade de transferência de um curso para o outro.

No ano de 1963, a Portaria 347, de 16 de setembro, definia a unificação das diretrizes do ensino comercial e industrial em torno da proposta do ginásio moderno, orientando-as para o trabalho, com a duração de quatro anos. O sistema educacional visava preparar a sua clientela para as necessidades do mercado de trabalho, substituindo o ensino de caráter acadêmico pelo ensino de formação profissional, a partir do segundo grau. 
Surgiu, na década de 1960, a teoria do "Capital Humano", conhecida no Brasil como "valor econômico da educação", que buscava o desenvolvimento do ser humano com o objetivo de melhorar a produtividade, por meio de investimento na educação.

Conforme assinala Frigotto, (1997)

No Brasil as reformas universitárias de 1968 e de $1^{\circ}$ e $2^{\circ}$ graus de 1971, a fundação do Mobral e inúmeros outros programas se estruturaram fundamentalmente tendo como suporte a teoria do Capital Humano.

A década de 1970 foi marcada pelo modelo tecnicista, como resultado da década anterior. Define-se o Capital Humano como produção de conhecimento que necessita de motivação para melhorar a sua produtividade; esse conhecimento é uma forma de capital e a tecnologia aplica-se ao capital, em função de aplicação do conhecimento e das descobertas no trabalho. Segundo CRAWFORD (1994), a organização econômica e social é centrada na posse da informação, do conhecimento e na utilização do Capital Humano. (grifo nosso).

\subsection{LDB 4024/61 e LDB 9394/96}

As mudanças que ocorreram na educação profissional, com a promulgação da Lei 9394/96 e a sua regulamentação através do Decreto 2208/97, foram significativas. Os reflexos dessas mudanças precisam ser analisados, considerando-se o período histórico que nos reporta à década de sessenta, pouco antes do golpe militar de 64 .

Segundo Souza e Silva (1997), antes de 1971 já existia no Brasil, durante a vigência da Lei 4024/61, o ensino profissional, que se configurava como um subsistema de educação formal, e que a LDB 9394/96 reproduz.

$\mathrm{Na}$ Lei 4024/61 a estrutura do ensino médio se configurava no formato de 2 ciclos, sendo curso ginasial de 4 anos e curso colegial de 3 anos, ambos compreendendo o ensino secundário e ensino técnico (industrial, agrícola, comercial e de formação de professores).

O currículo proposto para essa modalidade de ensino, bem como para os outros níveis da educação, nesta lei, não era um currículo fixo e rígido. Previa a descentralização para os Estados e para as escolas, que passam a poder agregar 
disciplinas optativas no currículo mínimo determinado pelo CFE. Entretanto elas não dispunham de recurso material suficiente nem de pessoal especializado para desenvolver novos currículos dentro das instituições de ensino. Foram mantidos, então, os antigos currículos.

Nesse cenário, as instituições de ensino estavam limitadas a desenvolver uma proposta coesa que pudesse fielmente atender à Lei 4024/61, uma vez que não dispunham de recursos; quando dispunham de recursos, material, humano ou técnico, estes não eram explorados de maneira racional e produtiva. A proposta dessa nova modalidade de ensino no que se refere à revisão dos seus currículos era uma oportunidade para a sociedade brasileira organizar o seu sistema de ensino de forma que atendesse o sistema geral de produção do país, em sintonia com os progressos sociais já alcançados.Porém, as formas de atuação política não foram suficientes para criar o sistema de que o país carecia, pois a compreensão sobre a educação como fator de desenvolvimento era ainda muito limitada e a educação escolar continuava voltada para técnicas e valores próprios da mentalidade pré-capitalista, enquanto o Brasil estava em plena expansão do capitalismo industrial.

Para Reis (1985) :

Durante muito tempo, os caminhos trilhados pela educação brasileira refletiram uma posição dicotômica quanto à questão da educação e trabalho. Na legislação educacional brasileira, anterior à Lei 4024/61 (...), não se descortinou a possibilidade de que a escola, como um todo, deixasse as suas características elitistas e pudesse vir a ter como objetivo preparar os futuros cidadãos para o trabalho (...)

Havia apenas um "ensino secundário" para possibilitar o acesso ao ensino superior. Pouco a pouco, com a ascensão de outras camadas sociais, surgem as escolas de ofícios, de qualquer forma também "secundárias".

O nosso sistema educacional sempre esteve aquém daquilo que o país exigia. Preocupava-se mais com o ensino propedêutico, que era destinado às classes dominantes e que traduzia a sua ideologia. Restava a classe menos favorecida a busca de uma formação profissionalizante, uma vez que esta encaminhava diretamente para o mercado-de-trabalho.

Refletindo sobre este aspecto, Giuliani (1994) afirma que: 
Em 1964, o país atravessava um momento histórico-sóciopolítico atípico, com a implantação do regime militar. A economia apresentava-se com baixa produtividade no setor industrial e a educação, com uma proposta inadequada, visava atender às necessidades do mercado de trabalho (...)

O Governo procurava, na década de 1960, por meio da educação profissionalizante, o treinamento da mão-de-obra para o mercado de trabalho. Era a busca do aumento da produtividade por intermédio da qualificação da força de trabalho.

Na década de 1970, a aprovação da Lei 5692/71, no ART. $4^{\circ}$ parágrafo $1^{\circ}$, pretendeu romper com a dualidade, substituindo o antigo ensino propedêutico e profissionalizante, por um sistema único com a finalidade de obter-se uma habilitação profissional conforme podemos constatar no texto da própria lei. A atenção voltada para o trabalho no ensino de $2^{\mathrm{o}}$ grau poderia ensejar habilitação profissional do estabelecimento de ensino (São Paulo, 1985).

Segundo SOUZA e SILVA (1997):

A Lei 5692/71, camuflada pelo discurso desenvolvimentista e apoiada na Teoria do Capital Humano procura corrigir este dualismo, buscando estruturar no sistema a escola única onde se integrariam o ensino comum e o ensino profissionalizante, porém. . . onde predominava o ensino geral (secundário), passou a predominar o ensino profissionalizante...

A Lei 5692/71 foi alvo de muitas críticas, como afirmam Franco (1994) e Kuenzer (1997), que fazem menção às dificuldades da sua implantação devido ao elevado custo das instalações e equipamentos necessários, à falta de professores qualificados para ministrar aulas e à dificuldade de convênio com empresas.

$\mathrm{Na}$ mesma lei, 5692/71 artigo 4, estabelece-se que os currículos teriam um núcleo comum obrigatório, em âmbito nacional, e uma parte diversificada, esta última determinada pelas unidades escolares, com base em uma relação de disciplinas elaborada pelos CEE, além de conteúdos mínimos exigidos para as habilitações profissionais e fixados pelo CFE (parágrafo único, B e E) . Os mínimos exigidos a cada uma das habilitações profissionais, disciplinas e conteúdos foram determinados no parecer CFE 45/72.

No parecer CFE 45/72, mais especificamente na introdução, mencionou-se que a LDB de 1961 (Lei 4024/61) foi omissa quanto ao aspecto da habilitação para o trabalho, 
fazendo apenas uma menção passageira no capítulo III, do título VII, sobre o ensino profissional. Além desta menção, a lei 4024/61 só faz referência à qualificação para o trabalho (MEC 149). A Lei 5692/71, em contrapartida, tem na educação mais técnica uma de suas notas dominantes.Os alunos concluintes do ensino médio, por meio da profisssionalização, teriam condições de suprir as necessidades das empresas públicas e privadas com relação à mão-de-obra qualificada.

Entretanto esses cursos de formação profissional caracterizavam-se pelo único objetivo que era o de ensinar a fazer, sem conhecimento da teoria sobre a ação, tornando-se um ato mecanicista, e segundo Stark, (2000):

por inadequação conceitual e por falta de condições materiais, a demanda por formação de mão-de-obra qualificada, nem de longe foi atendida o que gerou um novo estudo do CFE, por solicitação do então Ministro de Educação e Cultura, Ney Braga, resultando em novo parecer, o de número 76/75.

O objetivo, ainda que não explícito, era também o de impedir o ingresso dos jovens das camadas populares no ensino superior, conseqüentemente desviando o aluno para o mercado de trabalho e suprindo, assim, o mercado de profissionais qualificados.

O Parecer número 76/75 do CFE contempla a realização de habilitações básicas, não habilitando o cidadão para o exercício de uma ocupação especifica. Representava uma opção à profissionalização técnica no segundo grau.

Ainda no texto do Parecer 45/72, no que tange aos objetivos, os seus signatários apontam para o escalonamento dos vários estágios de formação profissional e que surgem, no texto da Lei 5692/71, assim hierarquizados:

1. Iniciação para o trabalho;

2. Aprendizagem para alunos de 14 a 18 anos;

3. Qualificação profissional;

4. Habilitação profissional;

A sondagem de aptidões (. . .) se fará mediante a utilização de métodos adequados;

A iniciação para o trabalho se fará, geralmente, nos ambientes didáticos já conhecidos como os de desenvolvimento das artes industriais, das práticas comerciais e dos serviços, das práticas agrícolas e da educação para o lar.

Aprendizagem profissional metódica se fará naturalmente na forma em que a desenvolvem o SENAI e o SENAC, com resultados mundialmente consagrados. 
A qualificação profissional em cursos intensivos (. . .) terá naturalmente o seu modelo no Programa Intensivo de Preparação de mão-de-obra.

A habilitação profissional nos estudos de $2^{\circ}$ grau será (....) aquela que mais se orienta para as ocupações que exigem domínio dos conhecimentos tecnológicos para utilização em técnicas mais especializadas (. . .) (São Paulo, 1985: 168/169).

As conseqüências da Lei $5692 / 71$ e os seus desdobramentos no $2^{\text {o }}$ grau apresentavam-se da seguinte forma:

- Extinção das antigas Escolas Normais que, com a profissionalização obrigatória, passaram para Curso de Habilitação em nível de $2^{\circ}$ grau (HINGEL, 1993);

- Obrigatoriedade da profissionalização, que procurou superar a discriminação existente entre ensino normal e técnico, e o ensino secundário. Este último era destinado aos que pretendiam seguir para o ensino superior, e aqueles, para a formação profissional de nível médio. Procurou reunir em um mesmo tipo de ensino a educação geral e a formação especial, dando a todos a possibilidade de seguir estudos ou condições para o exercício de uma profissão. Entretanto essa proposta não foi bem sucedida (HINGEL, 1993).

A decadência do ensino público, em geral, e da escola de ensino médio, em particular, nestes últimos anos, associada à excelente estrutura que as escolas técnicas foram adquirindo, fez com que elas se tornassem alvo de grande procura e levou à seletividade dos ingressantes. Como conseqüência, boa parte dos alunos dessas escolas técnicas manifestava interesse em prosseguir os estudos no ensino superior.

Conforme dados apresentados pelo próprio Ministro Murilo Hingel, na palestra aos senadores, $60 \%$ ou mais dos alunos vão tentar o vestibular e fazer o ensino superior, o que fugia completamente à idéia de terminalidade pretendida com esses cursos.

Em 18 de outubro de 1982 foi promulgada a Lei 7.044/82, que definiu a não obrigatoriedade da habilitação profissional no $2^{\circ}$ grau, caracterizando a indefinição do papel da escola mais uma reforma entre tantas reformas.

Em 20 de dezembro de 1996, foi promulgada a Lei 9.394/96 a qual estabeleceu as novas Diretrizes e Bases da Educação Nacional. 
A nova LDB estabeleceu o caráter de terminalidade para a educação profissional e de educação geral para o ensino médio pretensão sustentada pelo governo federal em 1993 e perceptível na fala do então Ministro da Educação:

Então, o que estamos querendo defender é a idéia de uma sugestão, onde não temos uma posição final a respeito dessa matéria e que talvez pudéssemos conceber o ensino médio em dois patamares: um realmente ensino médio voltado para a educação geral e um outro, acoplado a este primeiro (...) se abrisse a perspectiva da obtenção da formação profissional (...) (HINGEL, 1993)

A LDB 9394/96, no que se refere ao ensino médio, estabelece no seu artigo 36, inciso III, parágrafo $2^{\circ}$, que o ensino médio, atendida a formação geral do educando, poderá prepará-lo para o exercício de profissões técnicas.E, no parágrafo $4^{\circ}$ estabelece que:

A preparação geral para o trabalho e, facultativamente, a habilitação profissional poderão ser desenvolvidas nos próprios estabelecimentos de ensino médio ou em cooperação com instituições especializadas em educação profissional.

Há um capítulo na LDB 9394/96, especialmente dedicado à Educação Profissional, com apenas três artigos. O primeiro faz menção ao desenvolvimento de aptidões para a vida produtiva e define que o aluno poderá estar cursando o ensino médio ou superior e, concomitantemente, o ensino profissional (ART.39, parágrafo único); o segundo define a articulação entre educação profissional e ensino regular, ou educação continuada, em instituições especializadas ou ambiente de trabalho (Art. 40); o terceiro prevê uma avaliação que poderá certificar aquele que apresentar o conhecimento necessário, mesmo que não tenha freqüentado a escola (Art. 41) e determina a abertura de cursos especiais para a comunidade, condicionados à capacidade de aproveitamento, independentemente do nível de escolaridade.

Segundo Souza e Silva (1997), não há na LDB 9394/96 qualquer preocupação com a educação para o trabalho no ensino fundamental. A educação profissional passa a ser um processo de educação permanente, aberto aos egressos da escola formal e também aos trabalhadores em geral, jovens e adultos, tendo sempre como pressuposto uma boa formação geral por parte do aluno. Muito longe do que propunha a lei 5692/71, o ensino profissionalizante passa a ter uma dupla função de pós-secundário ao 
incorporar os cursos técnicos de nível médio ao sistema regular, estabelecendo a equivalência entre os cursos propedêuticos e os profissionalizantes.

O capítulo da educação profissional na LDB 9394/96 provocou muitas polêmicas no âmbito das escolas técnicas e das FATEC's, uma vez que os seus poucos artigos modificaram muito a estrutura já existente. A falta de informações, as contratações, a resistência às mudanças motivaram protestos e manifestações em todo o país especialmente em São Paulo, cidade que concentra o maior número de escolas técnicas.

Tais manifestações foram acirradas em conseqüência do Projeto de Lei 1603/96Lei Orgânica da Educação Média e Tecnológica, que orientava a LDB e que apresentava profundas mudanças para o ensino profissionalizante. Souza e Silva (1997) apontaram o objetivo central do projeto como sendo o de:

... desvincular o ensino profissional do ensino médio comum, integrar procedimentos da formação profissional (aquela que se obtém fora da escola) aos procedimentos escolares, valorizar qualificação por certificação e reestruturar a rede federal de ensino profissionalizante nos níveis técnico e tecnológico.

A polêmica criada em torno do projeto, a pressão da sociedade, as manifestações dos estudantes contra a reforma do ensino técnico, que ressaltava a separação entre a educação geral e a profissional, culminaram com a retirada do projeto. Mas, quatro meses após a promulgação da Lei 9394/96, em dezembro de 96, o ensino profissional foi regulamentado através de Decreto sob o no 2208 em 17 de abril de 1997. O decreto substituiu o PL 1603/96, atendeu algumas das reivindicações feitas pela sociedade, mas manteve a sua essência, tais como a modularização dos cursos técnicos de nível médio e a certificação por competências.

Passaremos a analisar a regulamentação da educação profissional com o Decreto 2208/97.

\subsection{Decreto 2208/97}

Vejamos quais as mudanças previstas para a educação profissional, de acordo com as determinações do Decreto $n^{\circ}$ 2208/97, nos seguintes aspectos: objetivos, 
educação profissional, instituições federais, educação profissional de nível técnico, ensino médio, currículos, decreto e ensino técnico.

$1^{\circ}$ ) Quanto aos objetivos, fala-se em:

Art. $1^{o}$ : promover a transição entre a escola e o mundo do trabalho. . . proporcionar a formação de profissionais, aptos a exercerem atividades especificas no trabalho. . . e qualificar, reprofissionalizar e atualizar jovens e adultos trabalhadores...

$\left.2^{\circ}\right)$ A educação profissional é dividida em três níveis $\left(\right.$ Art. $\left.3^{\circ}\right)$ :

I) Básico: destinado à qualificação, requalificação $e$ reprofissionalização de trabalhadores, independente de escolaridade prévia;

II) Técnico: destinado a proporcionar habilitação profissional a alunos matriculados ou egressos do ensino médio (. . .) ;

III) Tecnológico: correspondente a cursos de nível superior na área tecnológica, destinados a egressos do ensino médio e técnico (decreto n ${ }^{\circ} 2208 / 97-A r t .3^{\circ}$ ).

Souza e Silva (1997) fazem uma distinção entre formação profissional e educação profissional, ressaltando que existe similaridade entre ambas, mas que tratam de dois aspectos diferentes.

A formação profissional visa aprimorar o aluno trabalhador, nos processos de aprendizagem, qualificação, reciclagem e treinamento, constitui-se em atribuição das empresas e das agências $S$ (SENAC, SENAI, SENAR, etc) e tem seus procedimentos enraizados nas recomendações da OIT (...). A educação profissional obedece a critérios do formalismo legal e pedagógico, em cursos longos e seriados ou modulados, sob a supervisão dos órgãos administrativos dos sistemas de ensino (...) (grifo nosso).

Pedro Demo (1997) afirma que a concepção de educação profissional:

... está menos ligada ao domínio técnico de habilidades factuais do que ao saber pensar, tendo em vista que sua renovação permanente representa o que há de mais profissionalizante numa profissão (...) Diante da velocidade com que o conhecimento se inova e também envelhece, é improdutivo pretender acumulá-lo; (...) sua energia mais forte 
está, por isso, no saber pensar para melhor intervir, num processo permanente de renovação . (grifo nosso).

Considerando a importância do saber pensar, e não simplesmente do saber fazer, Demo (1997) afirma que... é indispensável saber fazer, para sempre renovar o fazer. Neste sentido é necessário que se estabeleça uma clara conexão entre o mundo profissional e do trabalho, mais do que com o "mundo" do emprego. Isto nos reporta às questões da empregabilidade, mas que na nova LDB, ainda segundo DEMO (1997), está no máximo no pano de fundo, bem lá no fundo.

$3^{\circ}$ ) As Instituições Federais, públicas e privadas sem fins lucrativos, são obrigadas a oferecer cursos profissionais de nível básico, atribuindo aos alunos no final dos cursos um certificado de qualificação profissional (Art. $4^{\circ}$ e seus parágrafos $1^{\circ}$ e $2^{\circ}$ ).

As habilitações profissionais eram oferecidas sem o desenvolvimento de programas destinados à qualificação e/ou requalificação de trabalhadores que não tinham um determinado nível de escolaridade. A obrigatoriedade acima referida denota a preocupação com a perda, por parte do trabalhador, de espaço num mercado de trabalho cada vez mais competitivo e especializado, que requer conhecimentos e habilidades de que ele não dispõe.Isso exigirá uma adaptação das instituições de ensino, que deverão repensar os seus novos programas e metodologias, além de instalações e equipamentos adequados às demandas emergentes do mercado de trabalho, para atendimento dessa nova clientela.

$4^{\circ}$ ) Uma outra grande novidade é que a educação profissional de nível técnico não se dará mais de forma integrada. Ela será oferecida apenas nas disciplinas específicas, ficando a parte propedêutica para o ensino médio. Assim, poderá ser oferecida de forma concomitante ou seqüencial ao ensino médio (Art. $5^{\circ}$ ).

Conforme reforça Souza e Silva (1997):

... embora a profissionalização se possa fazer, em regra, à margem do ensino médio, numa espécie de subsistema paralelo, do aluno que a ele se dirige (ao ensino profissionalizante), exige-se um pré-requisito indispensável : a prova de que dispõe de formação geral suficientemente abrangente (...).

$\left.5^{\circ}\right)$ No ensino médio poderão ser oferecidas disciplinas de caráter profissionalizante (até $25 \%$ da carga horária mínima), que poderão ser aproveitadas para as habilitações profissionais (Art. $5^{\circ}$, parágrafo único). $\mathrm{O}$ fato de o programa integrar 
disciplinas de caráter profissionalizante no ensino médio não significa que este formará o técnico para o trabalho.

$\left.6^{\circ}\right)$ Os currículos do ensino técnico poderão ser agrupados sob a forma de módulos e estes poderão ter caráter de terminalidade, dando direito ao certificado de qualificação profissional (Art. $8^{\circ}$ e seus parágrafos). O aluno terá o prazo máximo de cinco anos para a conclusão do curso, podendo cursar os módulos em diferentes instituições de ensino, sendo que o diploma de técnico em nível médio será outorgado pelo estabelecimento que conferiu o último certificado de qualificação profissional.

O referido decreto e o PL 1603/95 desencadearam muitas discussões, como assinalamos, e, hoje, após a sua promulgação, são motivos de preocupação por parte das instituições que deverão resolver os impasses que venham surgir no decorrer dos próximos anos.

Poderíamos apontar, como principal preocupação, o caso da procura por instituições que apresentam maiores facilidades no desenvolvimento das disciplinas e a conclusão do último módulo em instituições de renome. Tal fato poderá sobrecarregar as escolas mais conceituadas com alunos que busquem somente diplomas, mas ao mesmo tempo, poderá prejudicar o conceito dos alunos com a diplomação que lhes confere uma qualificação, no mínimo, duvidosa.

Como aspecto positivo, citamos o fato do aluno que se vê obrigado a deixar o curso antes do término do semestre, ou do ano, mas não perde o período que já cursou. Nesse caso terá, no mínimo, uma certificação de qualificação, fato que poderá estimular a continuidade dos estudos, posteriormente.

$7^{\circ}$ ) O decreto 2208/97 determina que as diretrizes curriculares nacionais, com as regras mínimas dos cursos, conteúdos mínimos, habilidades e competência básicas, por área profissional, serão estabelecidas pelo MEC, ouvido o CNE (Art. $6^{\circ}$, inciso I).

Quando da promulgação da Lei 9394/96 foram revogadas todas as disposições do artigo 92 e a mesma passou a vigorar a partir de 20 de dezembro de 1996. As instituições que promovem a educação profissional tiveram dificuldades para reorganizar sua atuação no nível básico. Não há necessidade de regulamentação curricular, ficando a critério de cada instituição de ensino aquilo que diz respeito aos cursos de $2^{\circ} \mathrm{Grau}$; o CNE teve aprovado o parecer $\mathrm{n}^{\circ}$ 07/97, em que ressalta a continuidade da vigência, em nível nacional, do Parecer do CFE nº 45/72. Também houve uma manifestação do CEE/SP, em outubro de 1997, que aponta para as diretrizes contidas na indicação CEE/SP $n^{\circ}$ 14/97 ( $1^{\circ}$ de outubro de 1997). Essa indicação 
determina que deve ser observado o parecer CFE n 45/72 nos cursos técnicos, até que sejam definidas as novas diretrizes curriculares nacionais e currículos básicos, reforçando o Parecer do CNE $n^{\circ}$ 05/97.O parecer CNE/CBE 17/97 e o 15/98 determinam que a articulação entre a educação básica e a técnica deve definir as quais as competências gerais que as escolas esperam que os alunos levem do ensino médio. Nesse sentido, tanto a LDB, em especial no artigo 41, quanto o Decreto Federal número 2.208/97, estabelecem que disciplinas de caráter profissionalizante cursadas no ensino médio podem ser aproveitadas no currículo de habilitação profissional de técnico de nível médio, mantendo-se assim as identidades curriculares próprias, preservando-se a necessária articulação.

$8^{\circ}$ ) Define-se, pelo decreto número 2208/97 quem poderá ministrar as disciplinas no ensino técnico. Surge a possibilidade de contratação de professores, instrutores e monitores com comprovada experiência profissional, desde que preparados para o magistério, previamente ou em serviço, através de cursos regulares de licenciatura ou de programas especiais de formação pedagógica (Art. 9º). Souza e Silva (1997) alertam para o fato, dizendo que os professores deverão ser preparados para o magistério, através de cursos regulares de licenciatura e de programas especiais de habilitação. 


\section{A INSTITUIÇÃO SENAC: PARCEIRA NA PESQUISA E INTERVENÇÃO}

No início da década de 1940, o processo de expansão da indústria exigia a preparação de mão-de-obra qualificada. Necessitava-se, urgentemente, de núcleos de formação profissional, a fim de atender o gradativo e crescente mercado na área da indústria.

Entretanto, o sistema educacional não possuía a infra-estrutura necessária para o desenvolvimento de mão-de-obra qualificada, com formação em larga escala, uma vez que não dispunha de recursos e de equipamentos adequados para a formação profissional. O setor industrial, por sua vez, e como se ressaltou, ansiava por uma formação mínima do operariado, necessitando para isso de uma ação rápida, prática e eficiente do Governo.

Diante de tal realidade e necessidade, o Governo criou um sistema de ensino paralelo ao sistema oficial, organizado em convênio com as indústrias e com a mediação da Confederação Nacional das Indústrias.

Concretizou-se, por meio do Decreto-lei 4.048, de 22 de janeiro de 1942, a criação do Serviço Nacional de Aprendizagem dos Industriários e, posteriormente, o Serviço Nacional de Aprendizagem Industrial (SENAI), com o objetivo de organizar e administrar escolas de aprendizagem industrial em todo o país.

A Lei Orgânica do Ensino Industrial (Decreto-Lei $n^{0} 4.073$ / 42) tinha como meta à preparação dos aprendizes menores dos estabelecimentos industriais em "cursos de formação e continuação para trabalhadores não sujeitos à aprendizagem" e para tal o SENAI deveria ser organizado e dirigido pela Confederação Nacional das Indústrias e mantido pela contribuição dos estabelecimentos industriais a ela filiados.

O governo baixou ainda dois outros decretos-lei:

$\left.1^{\circ}\right) n^{\circ} 4.481$ de 16 de julho de 1942, que obrigava os estabelecimentos industriais a empregarem aprendizes e menores num total de $8 \%$ do número de operários neles existentes e matriculá-los nas escolas mantidas pelo SENAI. 
A lei exigia prioridade para os filhos (incluindo os órfãos e irmãos) dos empregados e a manutenção de dois tipos de escolas:

a) as estabelecidas junto às próprias empresas;

b) as escolas mantidas pelo sistema oficial de ensino.

Notava-se desde o início a preocupação em oferecer uma grade curricular que contemplasse a formação geral, a formação técnica e a formação prática das operações do ofício, com o objetivo de dotar o profissional com uma visão totalizante, que superasse uma visão linear, única e exclusivamente técnica. O Governo determinou, com o referido Decreto-lei, que se favorecessem os aprendizes, para que estes pudessem suprir as necessidades das indústrias; os cursos, por sua vez, deveriam funcionar durante o período de trabalho.

$\left.2^{\circ}\right)$ Decreto-Lei número 4.436 de 07 de novembro de 1942:

- Este Decreto-lei ampliava o âmbito de ação do SENAI, determinando que sua rede de escolas profissionais atingisse o setor dos transportes, das comunicações e da pesca.

- Determinava que as escolas passassem a ministrar cursos de aprendizagem, ensino de continuação, aperfeiçoamento e especialização, gerando ampliação no que tangia a:

- Setores de produção: qualificação de pessoal em várias áreas de trabalho, com diversificação maior dos seus cursos;

- Níveis dos Cursos (Ampliação): inclusão do aperfeiçoamento e especialização, e, conseqüentemente, da possibilidade de reciclagem profissional e da formação de professores.

Outra medida do governo, o Decreto-lei 4.984, de 21 de novembro de 1942, determinava que as empresas oficiais com mais de 100 empregados poderiam manter, por conta própria, uma escola de aprendizagem destinada à formação profissional de seus aprendizes, oferecendo ensino de continuação, de aperfeiçoamento e especialização de seus trabalhadores, desde que as instituições se articulassem, previamente, com o sistema de escolas do SENAI.

O Decreto-lei número 8.621/46, de 10 de janeiro de 1946, surgiu após quatro anos da criação do SENAI e determinava a criação do Serviço Nacional de Aprendizagem Comercial-SENAC. 
A estrutura do SENAC era a mesma do SENAI diferindo somente no fato de o SENAC pertencer ao setor comercial e ser dirigido e organizado pela Confederação Nacional do Comércio.

O Decreto-lei $n^{o} 8.622 / 46$, também de 10 de janeiro de 1946, estipulava a obrigação de as empresas comerciais empregarem menores e matriculá-los nas escolas de aprendizagem do SENAC, a exemplo do que determinava o Decreto 4.481, relativo ao SENAI.

A atuação desses órgãos ligados ao ensino profissional no Brasil torna-os, atualmente, responsáveis pela manutenção da maior rede de escolas profissionais do país. As camadas superiores e as camadas médias seguiam o ensino secundário e superior; as camadas populares procuravam as escolas primárias e as escolas profissionais.

O ensino profissional passou, depois da criação dos decretos que regulamentaram as leis orgânicas, a ministrar cursos de duração igual à do ensino secundário, além de cursos de aprendizagem e de curta duração.

O SENAI e o SENAC tiveram êxito na preparação da mão-de-obra com os cursos de aprendizagem de preparação elementar e rápida, uma vez que o sistema oficial de ensino não tinha condições de realizar o treinamento rápido de mão-de-obra para atender à expansão econômica da época e conseqüentemente à demanda de profissionais qualificados.

Os jovens que procuravam o SENAC e o SENAI já exerciam uma função dentro do mercado de trabalho; conseqüentemente, não freqüentavam o sistema oficial. Além da possibilidade de almejar um crescimento profissional, os alunos que estudavam em escolas do "sistema S" ainda recebiam uma "ajuda de custo", ou seja, eram pagos para estudar, o que representava grande atrativo para a população mais carente.

\subsection{Histórico}

No início da década de 1940, o processo de expansão da indústria exigia a preparação de mão-de-obra qualificada. Necessitava-se, urgentemente, de núcleos de formação profissional, a fim de atender o gradativo e crescente mercado de trabalho na área da indústria. 
Entretanto, as classes sociais média e altas não tinham interesse em incrementar o ensino profissional, nem tampouco o sistema educacional estava preparado para o desenvolvimento de mão-de-obra qualificada, com formação mínima profissionalizante do operariado. A indústria necessitava de uma ação rápida, prática e eficiente.

As condições de vida da população mais pobre as têm levado a vislumbrar a profissionalização como um dos meios de solução imediata de seus problemas materiais, por outro lado, temos a complexidade de fatores que dificultam a ascensão social que os trabalhadores imaginariamente desejam adquirir (ROCHA, 1997).

Diante de tal realidade e necessidade, o presidente Getúlio Vargas, no ano de 1942, assinou o decreto de criação do SENAI, o qual deveria atuar como um sistema de ensino paralelo ao sistema oficial, organizado em convênio com as indústrias e com a mediação da Confederação Nacional das Indústrias.

Concretizou-se, por meio do Decreto-lei 4.048, de 22 de janeiro de 1942, a criação do Serviço Nacional de Aprendizagem dos Industriários e, posteriormente, o Serviço Nacional de Aprendizagem Industrial (SENAI), com o objetivo de organizar e administrar escolas de aprendizagem industrial em todo o país.

O Ensino Industrial tinha como meta à preparação dos menores aprendizes dos estabelecimentos industriais em "cursos de formação e continuação para trabalhadores não sujeitos à aprendizagem”. Para atender a esse objetivo o SENAI deveria ser organizado e dirigido pela Confederação Nacional das Indústrias e mantido pela contribuição dos estabelecimentos industriais a ela filiados.

Em 22 de janeiro de 1942 foi expedido o Decreto-Lei número 4.408/42, chamado de Lei Orgânica do Ensino Industrial. Houve a implantação de um "sistema de ensino profissional para a indústria", com as escolas de aprendizes artífices, posteriormente chamadas de escolas dos "S".

O Sistema "S" (SENAI, SESC, SENAC, dentre outras), é formado por escolas regulamentadas pelo Governo, por um sistema de ensino paralelo ao sistema oficial e destinado ao ensino profissionalizante para atender à indústria, ao comércio e áreas afins; esse ensino pode ser de nível básico, intermediário, de continuação, aperfeiçoamento e/ou especialização. 
Os cursos do sistema $\mathrm{S}$, especificamente aqueles do SENAI e SENAC, visavam possibilitar a maior qualificação de pessoal em várias áreas de trabalho, procurando obter maior diversificação e ampliação dos seus cursos com o objetivo de desenvolver melhor e amplamente esses profissionais anteriormente formados.

O SENAC- Serviço Nacional de Aprendizagem Comercial foi criado em 10 de janeiro de 1946, por um Decreto-Lei de no 8621/46, de abrangência nacional. É uma instituição privada e sem fins lucrativos.

O Governo Federal, por meio da Confederação do Comércio, organiza e administra a nova instituição SENAC, estabelecendo prioritariamente a organização e administração de escolas de aprendizagem comercial, a manutenção de cursos de especialização para empregados do comércio, a difusão e o aperfeiçoamento de formação para o comércio, por meio de acordos com estabelecimentos de ensino comercial.

O Governo Federal, concomitantemente à criação do SENAC, expediu o Decreto-Lei número 8622/46, definindo que as empresas que tivessem no seu quadro de funcionários no mínimo 90 empregados deveriam matricular no SENAC os menores, com idade mínima de 14 anos, na proporção de até $10 \%$ do total dos empregados. Esse trabalhador menor, matriculado no SENAC, seria remunerado pelo tempo dedicado à escola, devendo sua remuneração ser igual à da função ocupada na empresa e deveria também ter prioridade para admissão em estabelecimentos comerciais.

Segundo Riemma (1979), o Decreto número 8621/46, estabelecia que a aprendizagem dessa formação profissional deveria ser voltada para o estudo das disciplinas essenciais à preparação geral do empregado no comércio, por meio de disciplinas técnicas relativas ao setor de comércio, bem como atividades práticas das operações do referido setor.

Pesquisando os relatórios anuais do SENAC, constatamos que no ano da sua criação, em 1946, o SENAC tinha por objetivo dar assistência de caráter profissional, especialmente aos menores aprendizes e aos adultos empregados no comércio, tendo um caráter social e especificamente educacional, na sua essência e forma.

Mais adiante poderemos ver como se configura atualmente a função social do SENAC no que diz respeito aos comerciários e aos jovens aprendizes que buscam uma formação profissional voltada para a área de serviços.

A seguir, trataremos da estrutura do SENAC a partir da sua criação. Analisaremos os objetivos e a atuação dessa Instituição. 


\subsection{Missão e Atuação}

Como vimos anteriormente, o Serviço Nacional de Aprendizagem Comercial SENAC foi criado em 10 de janeiro de 1946, (Decreto-lei $n^{\circ}$ 8621/46), pelo Governo Federal, que atribuiu à Confederação do Comércio o encargo de organizar e administrar a nova Instituição.

Segundo Riemma (1979), o Decreto que institucionaliza o SENAC estabelece para ele as seguintes atribuições:

$1^{\circ}$. Organizar e administrar escolas de Aprendizagem Comercial;

$2^{\circ}$. Manter cursos de continuação ou práticos de especialização para os empregados adultos do comércio;

3. Colaborar com a obra de difusão e aperfeiçoamento do ensino comercial de formação e de ensino imediato que com ele se relaciona, para o que promoverá os acordos necessários, com os estabelecimentos de ensino comercial,

$4^{\circ}$. Em troca do auxílio financeiro que der aos estabelecimentos de ensino comercial, o SENAC exigirá sempre, melhoria do aparelhamento escolar, determinado número de matrículas gratuitas para comerciários, seus filhos, ou estudantes a que provadamente faltarem os recursos necessários.

O Decreto estabelecia ainda que a aprendizagem deveria realizar uma conveniente formação profissional, constando as atividades a seguir:

a) Estudo das disciplinas essenciais à preparação geral do empregado no comércio, assim como as práticas educativas que puderem ser ministradas;

b) Estudo das disciplinas técnicas relativas ao setor do ramo de comércio escolhido;

c) Prática das operações comuns ao referido setor. 
Os objetivos do SENAC, quando de sua criação em 1946, eram: organizar e administrar escolas de Aprendizagem Comercial; manter cursos de "continuidade", ou de especialização, para os empregados adultos do comércio; colaborar na obra de difusão e aperfeiçoamento do ensino comercial; oferecer matrículas gratuitas para comerciários e seus dependentes; realizar seleção de candidatos à admissão, como praticantes, e dar orientação profissional; contribuir para o desenvolvimento de pesquisas tecnológicas de interesse para o comércio.

Segundo pesquisa realizada por Riemma (1979), o relatório anual de 1946 do SENAC apresentava-o como uma nova instituição de caráter eminentemente social e especificamente educacional, na sua essência e forma.

O objetivo principal do SENAC era dar assistência de caráter profissional, especialmente aos menores aprendizes e aos adultos empregados no comércio.

As obrigações e encargos dos empregadores eram as seguintes:

- Para a manutenção do SENAC dever-se-ia recolher uma contribuição mensal no valor de $1 \%$ do total da folha de pagamento da empresa;

- A empresa deveria manter em seu quadro de pessoal 9 ou mais empregados matriculados no SENAC, ou seja, 10\% do total de empregados, constituídos por menores entre 14 e 18 anos;

- Durante o período normal de trabalho, as empresas deveriam matricular esses menores nas escolas de aprendizagem, onde receberiam o pagamento proporcional;

- A administração superior do SENAC deveria ser constituída por representantes dos sindicatos patronais, que receberiam pagamento em dinheiro.

Devido a essa razoável autonomia da administração do SENAC, ele tem podido contar em sua direção com pessoas que demonstram, ao menos por vivência empresarial, possuir experiência sobre as necessidades de mão-de-obra para o comércio.

Apresentamos algumas das principais mudanças de linha de ação e das diferentes soluções alternativas dadas às questões que vêm desafiando os administradores do SENAC. São elas:

- Em 1946 privilegiavam-se os cursos de Aprendizagem; 
- Em 1952 os programas são ampliados em: prática de ensino em cursos rápidos de curta duração, Ensino Supletivo (curso preparatório, incluindo as disciplinas do curso primário) que tinha por objetivo suprir as deficiências de escolaridade, equivalia ao primário e colocaria o aluno em condições de cursar os programas de aprendizagem e especialização para adultos.

- Em 1955, o SENAC passou a programar o curso comercial básico que, equivalia ao ginásio, com as vantagens de garantia de continuidade de estudos escolares para os alunos aprendizes do SENAC, em cursos ginasiais e colegiais do sistema oficial de ensino e diminuição do o alto índice de evasão escolar nos cursos de aprendizagem realizados pelo SENAC.

- Em 1959, instalaram -se cursos técnicos de contabilidade e de secretariado, na capital e no Interior;

- Em 1960, foram apresentadas sugestões específicas da Organização Internacional do Trabalho (OIT), com relação ao conceito de formação profissional acelerada;

- Em 1969 foram extintos, pelo SENAC São Paulo, os cursos técnicos de contabilidade e em 1973 foram extintos os Ginásios Comerciais;

- $\quad$ No período de 1973 a 1978 foi realizado um Convênio com a Secretaria da Educação, com o objetivo de complementar os cursos técnicos de $2^{\circ}$ grau;

As mudanças principais nesse período foram convenientes, como observa Riemma (1979):

De 1964 em diante, ocorreu uma brusca aceleração de propostas de cursos desenvolvidos pelo Departamento Regional, através de iniciativas centralizadas na Sede. A partir de 1972, com a implantação de metas quantitativas para atendimento, as unidades operativas foram autorizadas a planejar e realizar cursos, de acordo com as necessidades locais.

A adoção de valores quantitativos (justificados como esforço para democratizar as oportunidades educacionais e estender $o$ benefício da formação profissional ao maior número possivel de pessoas), associados aos valores de descentralização técnico-administrativa (justificados para garantir maior eficácia no atendimento das necessidades regionais), fizeram 
com que o leque de cursos oferecidos se multiplicasse mais ainda.

Nos anos 70, em especial 1972, aumentaram as matrículas nos cursos do SENAC, talvez em decorrência da iniciativa interna na Instituição, que fez a campanha "Projeto dos 300.000 alunos". Todavia interpretamos que tal fato estaria diretamente ligado à crise do ensino de 1968, que teve seu ponto marcante nos protestos de professores e alunos com relação à política educacional adotada pelo país. O ensino médio não atendia as necessidades do desenvolvimento interno, os cursos técnicos eram reduzidos a escolas particulares e o ensino superior era tido como um entrave ao desenvolvimento, pois não tinha o comprometimento de formar os profissionais exigidos e as universidades não assumiam o papel que lhes cabia. De acordo com Cunha (1989), as universidades e escolas isoladas não tinham autonomia, dependendo de autorização governamental para toda e qualquer providência. Era o governo que indicava reitores e diretores, fixava currículos e orçamentos.

Segundo Romanelli (1998), um dos aspectos da crise, portanto, está na crescente incapacidade de o sistema educacional oferecer os recursos humanos de que carece a expansão econômica. A acelerada industrialização brasileira criou uma quantidade e uma variedade de novos empregos, resultando na criação de novos serviços e conseqüentemente necessitando de infra-estrutura. Houve nesse momento uma transição dentro do sistema educacional provocada pela institucionalização da reforma da educação brasileira, a Reforma Universitária (Lei número 5.540/68) e a Reforma do Ensino de $1^{\circ}$ e $2^{\circ}$ graus (Lei número 5.692/71), que buscavam novas estratégias educacionais, procurando formar profissionais em curto prazo, segundo as novas exigências.

Em detrimento de tais mudanças ocorridas na educação brasileira, o SENAC adotou critérios quantitativos nos seus cursos do fator que gerou as seguintes mudanças dentro da Instituição:

1. Superação da visão educacional tradicional de formação profissional escolarizada;

2. Recuperação dos valores democráticos, não se priorizava mais as elites, as camadas economicamente superiores; 
3. Revisão dos programas de formação profissional, adequando-os às necessidades vigentes do mercado de trabalho;

4. Compromisso com uma visão social não imediatista ou utilitarista;

5. Diversificação das programações desenvolvidas e dos cursos oferecidos;

A enorme demanda educacional e a necessidade de uma nova adequação do sistema educacional ao modelo econômico, serviu como justificativa para a realização de vários convênios para assistência técnica e financeira, como os acordos MECUSAID, com a Agency for International Development (AID).

O Departamento Regional registrou em 1952 que era insuficiente o atendimento aos menores-aprendizes, ao contrário do que se propusera inicialmente.A proporção imposta pelo Decreto-lei de criação do SENAC, de que as empresas com 09 ou mais empregados deveriam matricular $10 \%$ dos seus empregados naquela instituição, não era atendida, o que se tornava preocupante.

Para sanar esse problema, o departamento regional criou uma seção de cadastros e fiscalização. Os responsáveis mantinham registro atualizado das empresas comerciais do Estado de São Paulo e do número de seus empregados. Desse modo, poderiam ser controlados os casos que se enquadravam na obrigatoriedade da matrícula de menores aprendizes.

O objetivo do departamento regional era de que os responsáveis pelo projeto do SENAC visitassem, na época oportuna, as empresas comerciais, a fim de verificar se elas estavam encaminhando os $10 \%$ dos seus empregados para realizarem cursos na Instituição SENAC, a fim de elevar a quota obrigatória de matrícula. Entretanto a lei não era cumprida pela maioria.

As justificativas para tal descaso das empresas eram: as multas atribuídas às empresas de valor irrisório, portanto, elas preferiam não cumprir a lei; os estudos da rede oficial de ensino não permitiam que os cursos de aprendizagem gerassem continuidade, portanto desestimulava os agentes; o menor aprendiz que deveria ser indicado pela empresa poderia matricular-se no curso regular. Entretanto, não poderia haver substituição para a mesma vaga por um outro menor, em curso já iniciado. 
Surgiram, ainda no ano de 1952, os cursos de aprendizagem com o curso comercial básico (ginásio comercial), fator esse que contribuiu para aumentar a freqüência dos aprendizes.Tal fato estimulou o SENAC que, a partir de 1954, empenhou-se na proposta de manter ginásios comerciais, o que gerou uma redução sensível na evasão escolar. Entretanto, não obteve êxito. Em conseqüência, intensificou a fiscalização das empresas a fim de que elas cumprissem a lei.

Observava-se no SENAC uma certa divergência na condução de sua política administrativa. Os dirigentes defendiam o argumento de que o SENAC não tinha a responsabilidade de fiscalização, ou seja, não deveria desempenhar essa função junto aos empresários comerciais, uma vez que era uma instituição mantida pelo próprio comércio. Entendiam que esse papel era de responsabilidade do Estado.

No início dos anos 1960, o SENAC tinha como prioridade o atendimento destinado aos adultos.Os cursos de aprendizagem consumiam a maior parte das verbas destinadas à sua programação que era realizada por uma estrutura de ginásio comercial de forma modular e inovadora. Contudo, na aplicação da lei havia algumas controvérsias, como podemos observar a seguir:

- As autoridades regionais do Ministério do Trabalho não reconheciam os cursos do ginásio comercial como equivalentes aos de aprendizagem. Isso ocorria devido a uma visão restrita da aprendizagem, com foco voltado somente para o contexto industrial.

- O texto da lei afirmava que o menor deveria realizar cursos em período diurno, aproveitando parte do turno diário de trabalho. Por sua vez, as empresas julgavam que os menores regularmente matriculados nos cursos comerciais noturnos estavam isentos de realizar os cursos do SENAC no seu horário de trabalho, podendo ser feito no período noturno.

A partir de 1974/1975 admitiu-se formalmente a instalação de "cursos de aprendizagem", sem haver o serviço de controle e cadastro de fiscalização. O ginásio comercial acabou sendo substituído pelos cursos de aprendizagem, com carga horária reduzida e sem equivalência aos cursos do sistema oficial de ensino, afastando-se dos objetivos estabelecidos, quando da criação do SENAC.

Nos anos 70, instalou-se mais uma unidade voltada para os cursos de qualificação e aperfeiçoamento, sem vinculação com os programas de aprendizagem: o 
Grande Hotel São Pedro-Hotel Escola, que seguiu o mesmo modelo do restauranteescola do edifício “João Nunes Júnior”, da avenida Tiradentes, em São Paulo, capital.

Em 1972, com a criação do Hotel-Escola, o projeto dos 300.000 alunos aumentou consideravelmente a admissão de maiores nos cursos. Nesse contexto, abandonou-se a antiga orientação de atendimento ao trabalhador menor de idade, devido à dificuldade de controle sobre as empresas que sempre encontravam inúmeras formas de contornar a obrigatoriedade de matrículas dos aprendizes no SENAC.

Durante três décadas houve uma forte ambigüidade na relação entre o SENAC e as empresas ao mesmo tempo em que a organização buscava contato direto com as empresas para oferecer seus serviços, ela cobrava das empresas a obrigatoriedade legal de matrícula de menores aprendizes. Em 1949 do setor de colocação, que tinha o objetivo de encaminhar egressos dos cursos de aspirantes ao comércio, é que se estabeleceram vínculos entre o SENAC e as empresas.

Tentando aproximar-se mais das empresas, a partir de 1965, inicia-se um programa de visitas sistemáticas dos diretores das Escolas SENAC às firmas comerciais. Essas visitas eram estimuladas e controladas pela Administração Central.

Ainda em 1972 introduziram-se "metas quantitativas do SENAC", metas essas que deveriam garantir um crescente número de atendimento na formação profissional, intensificando as visitas às empresas comerciais, promovendo contatos com os sindicatos patronais do setor terciário e com autoridades e lideranças das comunidades.

Entre 1965 a 1970 criou-se a programação dos setores de orientação educacional e profissional das escolas SENAC. O objetivo era aproximar as escolas da empresa, por meio de reuniões com empregadores. De acordo com os relatórios anuais, essa ação serviu para estreitar mais a relação entre o SENAC e as empresas. Com isso, as empresas colocaram-se cada vez mais como clientes, passando a dividir com o trabalhador as atenções e deixando de ter obrigações e metas, como era a proposta inicial.

Segundo Riemma (1979):

Os decretos-lei $n^{o}$ s 8.621 e 8.622, embora não neguem a possibilidade de apropriação, pelas empresas, das atividades do SENAC, também não a afirmam explicitamente. Não obstante, o Primeiro Regulamento do SENAC, baixado pela Confederação Nacional do Comércio, prevê uma primeira 
abertura, ao estabelecer, entre os objetivos da Entidade, o de contribuir para o desenvolvimento de pesquisas tecnológicas de interesse para o comércio. Mais um passo foi dado no regulamento aprovado em 1967, e ainda em vigor, definindo entre outras finalidades do SENAC, a de promover a divulgação de novos métodos e técnicas de comercialização, assistindo, por esse meio, os empregadores na elaboração $e$ execução de programas de treinamento de pessoal dos diversos niveis de qualificação, e assistir, na medida de suas disponibilidades técnicas e financeiras, as empresas comerciais, no recrutamento, seleção e enquadramento de seu pessoal.

Em 1970, o SENAC deixou de restringir-se ao desenvolvimento de programas voltados somente para o comércio e passou a ter o foco voltado, também, para a indústria, com programas de desenvolvimento de gerentes para as empresas.

No ano de 1974, surgiu o PRODEC - Programa de Desenvolvimento da Pequena e Média Empresa Comercial. Este programa era mantido exclusivamente pelos recursos do SENAC, uma vez que eles visavam ao atendimento de pequenas e médias empresas.

O SENAC já tinha naquela época a preocupação voltada para a auto-sustentação; o objetivo era que as receitas cobrissem pelo menos os custos e não onerassem as disponibilidades financeiras do Departamento Regional. Para que tal objetivo se concretizasse, a instituição passou a atender grandes empresas comerciais e industriais que teriam condições de pagamento dos custos dos programas de assessoria. A ênfase desses programas de desenvolvimento empresarial atendia completamente às necessidades das empresas.

No ano de 1978 o SENAC criou na cidade de São Paulo, uma unidade voltada exclusivamente para o desenvolvimento de programas do setor de gestão nas áreas de turismo e hotelaria: o CEATEL - Centro de estudos de administração hoteleira, que deveria prestar consultoria às empresas da referida área.

\subsection{SENAC São Paulo}

Ao final da década de 1990, o SENAC contava com 55 unidades dentro do Estado de São Paulo, com 2.684 funcionários e realizava 405.866 atendimentos por ano. 
O objetivo do SENAC, segundo o seu relatório para a década de 1990, era proporcionar o desenvolvimento de Pessoas e Organizações para a sociedade do conhecimento, por meio de Ações Educacionais comprometidas com a Responsabilidade Social. (Relatório de Macroestratégias do SENAC para a década de 1990).

O SENAC entende por "Macroestratégia", um conjunto de ações a serem implantadas em determinadas áreas. Durante o decorrer da década, considerou como prioridade cumprir a sua função e sobreviver dentro do mercado que se mostrava cada vez mais competitivo.

Segundo o documento de trabalho do SENAC-SP (2000), "Formulação de Proposta Estratégica do SENAC" (2000) as macroestratégias do SENAC contemplam os seguintes aspectos:

Educação: tem por objetivo enfatizar a aprendizagem para a autonomia e o desenvolvimento de competências. A educação profissional é a razão de ser e o negócio central do SENAC/SP. Ela inclui, além do domínio operacional de determinados afazeres, a compreensão global do processo produtivo, a apropriação do saber tecnológico, a valorização da cultura do trabalho, o desenvolvimento do espírito empreendedor e de iniciativa, bem como a mobilização dos valores necessários à tomada de decisões com autonomia.

Este fator inserido na proposta do SENAC objetivava dar ênfase à aprendizagem voltada para o desenvolvimento de competências, autonomia e cidadania. Valoriza assim a competência profissional de cada aluno. Baseado no Parecer CNE-CEB número 04/99, de 08/12/99 conceitua como competência profissional à "capacidade de mobilizar, articular e colocar em ação valores, conhecimentos e habilidades necessários para o desempenho eficiente e eficaz de atividades requeridas pela natureza do trabalho". Esse processo educacional exige uma revisão no papel das instituições de ensino. Primeiramente elas deverão dirigir a organização curricular dos seus cursos para área profissional e não mais para a habilitação profissional. Deverão organizar as suas estruturas curriculares de forma que estejam voltadas para o desenvolvimento de competências individuais além de dar ênfase na identidade e utilidade dos cursos em relação ao mercado de trabalho. Em segundo lugar, deverá ser revisto o papel do professor. Este redirecionará a sua atenção do ensino na transmissão de conteúdos e 
respectivas disciplinas para o processo de aprendizagem do aluno. A sua missão será a de mediar o processo de aprendizagem.

O desenvolvimento de competência do profissional está atrelado ao conceito de empregabilidade, e visa atender às novas demandas e especificidades, como a de formar profissionais flexíveis, capazes de lidar com a incerteza em processos dinâmicos, nos quais o profissional tem que tomar decisões rápidas e eficientes em face de situações novas.

Pessoas: é a essência da vantagem competitiva do SENAC São Paulo. Esta macroestratégia visa desenvolver e manter pessoas e equipes competentes, motivadas e com alta capacidade de agregação de valor à organização e aos clientes. É uma das principais opções estratégicas do SENAC.

Este fator é considerado pelas organizações competitivas dentro do mercado-detrabalho a sua essência, uma vez que as pessoas são o principal fator estratégico dentro de uma organização, apresentando-se como agentes detentores de recursos intelectuais e comportamentais críticos para a implementação da estratégia. As pessoas são agentes que administram recursos para a consecução de resultados.

Responsabilidade Social: que se destina à educação de pessoas, à inclusão social e ao exercício de uma ação comunitária exemplar.

A responsabilidade e o compromisso com a sociedade devem ser exercidos em prática com a consciência das instituições de ensino, desenvolvendo um conjunto de ações educacionais voltadas para a promoção da cidadania e da qualidade de vida.

Internacionalização: para a instituição SENAC significa estar disponivel, em sintonia e inserida no mercado.

Este aspecto da cultura contemporânea exige um contínuo e consciente esforço das organizações, uma vez que as inovações das diferentes áreas do conhecimento e os padrões de qualidade não se limitam mais a fronteiras regionais. Buscar novas experiências junto de instituições de ensino bem sucedidas, além de tentar estabelecer 
novos acordos de cooperação ou parcerias, por meio de trocas de tecnologias. São metas que as grandes instituições não podem deixar de cumprir.

Tecnologia da informação: tem a preocupação voltada para o desenvolvimento e consolidação da dimensão digital do SENAC São Paulo.

As instituições de ensino incorporam cada vez mais o uso da tecnologia da informática, tanto nos serviços oferecidos quanto nas atividades administrativas. No entanto, os educadores devem estar atentos à velocidade, ao volume de informações e à qualidade das mesmas, conduzindo o aluno a refletir e a selecioná-las transformando-as em conhecimento.

Auto-sustentabilidade operacional: visa assegurar o
crescimento e o desenvolvimento auto-sustentado da
instituição na busca da sobrevivência rumo ao objetivo de
crescimento constantes, compativeis com as necessidades da
realidade mercadológica. Por meio do incremento das receitas
advindas das operações, a geração de receitas próprias
viabiliza a ampliação dos investimentos. Além disso, propicia
a manutenção de reservas financeiras como garantia de
investimento e fator de estabilidade administrativa.

O alcance dessa relativa independência, ou estabilidade financeira, não é uma meta exclusiva à instituição SENAC, e sim a toda organização ativa e competitiva dentro do mercado de trabalho, que visa cumprir os seus objetivos, buscando melhoria continua no desenvolvimento do seu trabalho, bem como na do produto oferecido ao consumidor.

Organização e Gestão: tem o SENAC por objetivo desenvolver e consolidar um modelo dinâmico, flexível e empreendedor. $O$ principal instrumento para a gestão da ação institucional são os conceitos e as práticas de marketing. A sua adoção significa a abertura da Instituição para o mercado, para os clientes atuais e potenciais, bem como a permeabilização a influências externas que contribuam para o seu desenvolvimento.

Dentro desta perspectivas e na busca de permanência e reconhecimento no mercado de trabalho, as instituições têm se mostrado atentas em despertar nas suas 
equipes uma ação integrada por meio da liderança e da gestão das pessoas com relação ao desenvolvimento do seu trabalho, rumo a resultados ágeis, sinalizando o desenvolvimento da criatividade e da criticidade dentro da equipe de trabalho visando uma atitudes flexível frente ao mercado competitivo que se impõe cada vez mais forte.

Abaixo buscamos apresentar o desenvolvimento do Senac na formação profissional em hotelaria.

O Governador do Estado André Franco Montoro, no ano de 1983, procurou o SENAC para propor que o mesmo desenvolvesse um trabalho semelhante ao do Grande Hotel São Pedro em dois outros hotéis que pertenciam ao governo do Estado de São Paulo, situados em Águas de Lindóia e Campos do Jordão, respectivamente.

O SENAC recusou o Hotel de Águas de Lindóia por ser de pequeno porte e não ter espaço físico suficiente para o desenvolvimento das atividades necessárias. Com relação ao Hotel de Campos do Jordão, o SENAC interessou-se pela localidade, que dispunha de rodovias que facilitavam o acesso, e também a estrutura do Hotel era adequada à formação de profissionais.

A proposta inicial do governo era de que o SENAC assumisse o Hotel de Campos do Jordão em situação semelhante ao de Águas de São Pedro, ou seja, sistema de comodato ${ }^{5}$ por cinqüenta anos.

No ano de 1984, em negociação com o Governador de São Paulo, o SENAC se propôs a assumir o Hotel de Campos do Jordão desde que fosse efetuada a doação definitiva desse Hotel e do Hotel de Águas de São Pedro, rompendo, no caso do Grande Hotel de Águas de São Pedro, com o acordo de comodato.

Além dessa exigência, o SENAC solicitou também que o FUMEST - Fundação de Melhoria das Estâncias de São Paulo - fechasse o Hotel de Campos do Jordão, para entregá-lo isento de qualquer problema da administração anterior. Por último, propôs que as obras fossem coordenadas pelo próprio SENAC, tendo este autonomia para definir o cronograma do início de funcionamento do hotel-escola.

As condições propostas foram aceitas e o Grande Hotel São Pedro e o de Campos do Jordão passaram definitivamente para o SENAC com o objetivo de preparação de profissionais na área especifica de serviços para turismo e hotelaria.

\footnotetext{
${ }^{5}$ Repasse do empreendimento para ser administrado por um determinado período em que o investidor explorará o local e/ou empreendimento, devendo este fazer investimentos para sua melhoria. Findado o período de contrato estabelecido previamente, o empreendimento deverá voltar ao proprietário.
} 


\title{
5.4 Grande Hotel São Pedro e Hotel Escola Senac de Águas de São Pedro
}

\author{
Para apresentar o Grande Hotel São Pedro - Hotel Escola SENAC, vamos
} anteriormente procurar descrever rapidamente o município no qual ele está situado.

\subsection{O Município de Águas de São Pedro}

O Município de Águas de São Pedro fica localizado a $26 \mathrm{~km}$ da cidade de Piracicaba, sendo o menor município do Brasil, com apenas $2,6 \mathrm{~km}^{2}$. Foi considerado o que apresenta a melhor qualidade de vida no Brasil, segundo um estudo estatístico do IBGE realizado no ano de 1996 nas estâncias turísticas, estudo este disponível na Prefeitura de Águas de São Pedro. Possui clima temperado, com temperaturas médias de 21 graus $\mathrm{C}$, mínima de 08 graus $\mathrm{C}$ e máxima de 34 graus $\mathrm{C}$, com altitude de 530 metros.

Com a crise do café na década de 1920, especialmente em 1929, muitos fazendeiros abandonaram a atividade de cultivo de café e venderam suas fazendas. Dr. Octávio de Moura Andrade, morador de Brotas, na qualidade de advogado e com a missão de resolver problemas de fazendeiros chegou à cidade de São Pedro no ano de 1934 e, durante a sua estada no município, tomou conhecimento do poder terapêutico das águas ${ }^{6}$ encontradas no subsolo da fazenda do Sr. Ângelo Franzin. Amostras haviam

\footnotetext{
${ }^{6}$ Propriedades terapêuticas das águas:

Águas minerais bicarbonatadas sólidas: indicadas nas dispepsias, gastrites, úlceras gastroduoneis, hepatites, colecistiles, diabetes e moléstias da nutrição;

Águas minerais carbogasosas: diuréticas, são indicadas no tratamento das moléstias dos rins, do fígado, litíase renal, vesicular, dispepsias hipoácidas, nas moléstias cárdio-renais e como estimulante do apetite, em pequenas doses;

Águas bicarbonatadas mistas: indicadas no tratamento das moléstias gastrintestinais, hepatite, dispepsia e moléstias renais;

Águas iodadas: Apropriadas para o tratamento da arteriosclerose, reumatismo, insuficiência tireoidiana, bócio e moléstias do fígado e rins; Águas sulfurosas: empregadas no tratamento das moléstias alérgicas, eczema, artrite e reumatismo;

Águas ferruginosas: indicadas no tratamento das anemias ferroprivas e como estimulante do metabolismo;

Águas minerais cloretadas: indicadas no tratamento das moléstias gastrintestinais, gastrites, pancreatites, hepatites e moléstias renais;

Águas minerais bicarbonatadas cloretadas: mesmas indicações terapêuticas das águas minerais cloretadas; Águas minerais bicarbonatadas cloro-sulfatadas: contendo bicarbonato, cloreto e sulfato alcalinos, são indicadas no tratamento das moléstias do aparelho digestivo, da nutrição, artritismo e eczemas;

Águas minerais sulfurosas bicarbonatadas: utilizadas por via oral e em banhos, no tratamento das moléstias da pele, nas afecções reumáticas, de fundo alérgico e como estimulante das funções gastrintestinais;

Águas minerais sulfurosas - bicarbonatadas e sulfatadas: bastante alcalinas, são indicadas no tratamento do artritismo, gastrite e moléstias da pele;

Águas sulfurosas bicarbonatadas cloro - sulfatadas: indicadas no tratamento do reumatismo crônico, dispepsias, afecções hepáticas e como estimulante do metabolismo;
} 
sido encaminhadas para análises do IPT, que constatou as suas propriedades terapêuticas. As águas medicinais tinham sido casualmente encontradas, quando executavam perfurações na busca de petróleo. Ainda nesse período, Dr. Octávio de Moura Andrade visitou o precário balneário existente, construído pelo Sr. Ângelo Franzin, e decidiu melhorar as suas instalações.

Dr. Octávio de Moura Andrade empenhou-se na fundação da primeira estância turística do Estado de São Paulo, o Município de Águas de São Pedro, sendo que, para isso comprou a área de terra formada pela fonte de água, além de 650 alqueires inicialmente adquiridos. Ele iniciou a reforma do balneário, fundando a empresa "Águas Sulfídricas e Thermais de São Pedro S.A" e contratou um urbanista, o Sr. Jorge de Macedo Vieira, pois tinha como meta planejar não somente um Hotel mas toda uma cidade, destinada a ser estância termal.

Com a inauguração em 25 de julho de 1940 do Grande Hotel São Pedro, concretizou-se a fundação da cidade de Águas de São Pedro. O planejamento primeiramente visava à fixação de pessoas no lugar, tornando a cidade habitada, com construção de casas para os operários que trabalhavam nas obras do município e do Grande Hotel e também para os funcionários que trabalhavam no Hotel. Com esse objetivo, o Dr. Octávio construiu casas e vendeu por um custo simbólico, para que cada funcionário tivesse a oportunidade de adquirir sua própria moradia. As vilas de casas eram chamadas de Vila Operária, Vila Honolulu, Vila Bela, Vila Califórnia.

O Município de Águas de São Pedro se emancipou pela lei estadual número 233, de 24/12/1948 e teve a sua publicação no Dário Oficial em janeiro de 1949.

Atualmente [2006] a população fixa do Município é de aproximadamente 1.600 pessoas, sendo a cidade apropriada para repouso físico e mental. De segunda a sextafeira a cidade é habitada pelos munícipes e por alunos da Faculdade do SENAC e nos finais de semana é freqüentada, na sua maioria, por turistas de toda região, e de cidades mais distantes, como da grande São Paulo. A maioria possui casas de temporada.

Águas de São Pedro, segundo Ruy Bueno (1990), é uma cidade que foi projetada para fins residenciais, hidroterápicos, climáticos e de repouso. Para ela não foi previsto grande comércio ou setor industrial.

Até o ano de 1994 a população que habitava a cidade de Águas de São Pedro, desde a sua fundação, era considerada idosa. No ano de 1995 o primeiro curso superior

Águas minerais ferruginosas bicarbonatadas: contendo ferro, bicarbonato alcalino e alcalino - ferroso, são indicadas no tratamento das anemias ferroprivas. 
em Águas de São Pedro e demais cursos foram instalados. A cidade passou a ser freqüentada por jovens que residem temporariamente no município, os quais, em sua maioria, são estudantes do SENAC. Na cidade não existem carpintarias, marcenarias, ou qualquer tipo de confecções. Isso a diferencia de qualquer outro município; são permitidos apenas pequenos estabelecimentos comerciais de artesanato, farmácias, pronto-socorro, hotéis e restaurantes.

O Município de Águas de São Pedro não possui zona rural e está localizado dentro do Município de São Pedro, da qual fica distante 6,0 km. Em São Pedro, há comércio regular e pequenas indústrias que atendem perfeitamente a população de Águas de São Pedro.

\subsection{Origens do Grande Hotel}

O parque, que tem o nome do fundador do município, Dr. Octavio de Moura Andrade $^{7}$, com uma área de 968.000 hectares é considerado um dos cartões postais da cidade. Ele está inserido na área que pertence ao Grande Hotel, chamado primeiramente de "a pedra fundamental do município" o qual tem o seu nome oficial de Grande Hotel. Foi inaugurado em julho de 1940, data oficial de fundação da cidade, uma vez que o Hotel foi fundado juntamente com o município.

Em 1951, o Governo do Estado lançou, segundo a entrevista realizada com o Dr. Antonio Falcão de Andrade, a campanha do petróleo. A sua primeira medida foi tomar posse de todas as terras que tivessem produtividade do solo, com a campanha de nacionalização do subsolo. O Governo, nesse mesmo ano, desapropriou o Grande Hotel São Pedro, uma vez que o hotel era de propriedade dos irmãos Moura Andrade e os mesmos eram proprietários também das águas sulfídricas do município. Nesse período, o Sr. Auro de Moura Andrade, primo dos proprietários do Grande Hotel, situava-se politicamente em oposição ao governo de Ademar de Barros, fato este que impulsionou o Governo a efetuar a desapropriação dos direitos de exploração das águas medicinais, bem como o Grande Hotel.

7 A praça onde está situado o Grande Hotel São Pedro-Hotel Escola SENAC recebe o nome do Sr. Octávio de Moura Andrade, fundador do município. 
Em 1954, o Grande Hotel foi administrado pelo Governo do Estado, representado pelo Dr.Mauricio Magalhães de Carvalho ${ }^{8}$. Nesse mesmo ano foi aberta a concorrência pública do empreendimento para o seu arrendamento. A firma que ganhou a concorrência para administração do hotel foi "Termas de Lindóia", administrada pelo Sr. Benjamin Feinberger, que obteve um contrato de arrendamento de quinze anos e que deveria vigorar no período de 1955 a 1970.

O Sr. Benjamin Feinberger devolveu em 1960 o Grande Hotel para o Governo do Estado, deixando assim a sua administração e possibilitando que outras empresas viessem a assumir a gestão do referido empreendimento.

Os irmãos Moura Andrade compraram em 1960 a empresa "Termas de Lindóia" mudando o seu nome para "Companhia de Hotéis Octávio de Moura Andrade" e cumpriram o contrato de arrendamento. O prazo de vencimento do contrato de arrendamento do Grande Hotel venceria no ano de 1970. Os irmãos Moura Andrade ficaram na administração do Grande Hotel até 1969, ano em que o SENAC assumiu.

Em 1967, o então Governador de Estado Roberto Abreu Sodré consultou os irmãos Moura Andrade, que estavam administrando o empreendimento hoteleiro, sobre a possibilidade de romper o contrato de arrendamento em 1969, com o objetivo de repassar a gestão da administração do Grande Hotel para o SENAC, uma vez que a instituição manifestou tal interesse.

Em 1968, o Governador do Estado, em negociação com o SENAC, propôs que o mesmo assumisse todos os hotéis que estavam sob a sua administração. O governo do Estado, por intermediação do FUMESP - Fundo de Melhoria às Estâncias Turísticas de São Paulo, estava enfrentando dificuldades para administrar os hotéis.

Os irmãos Moura Andrade anteciparam o rompimento do contrato, uma vez que a instalação do SENAC no município viria beneficiar a cidade e a região em virtude da experiência e programas educacionais já desenvolvidos por essa renomada instituição. Repassaram o Grande Hotel para ser administrado pelo SENAC, com o objetivo de instalar a escola de hotelaria. Os primeiros cursos implantados foram de recepcionista, de garçom básico e o cozinheiro básico ${ }^{9}$.

O SENAC havia iniciado essa experiência em São Paulo com o restaurante "Lauro Cardoso de Almeida" e estava tendo excelentes resultados.

${ }^{8}$ Foi diretor geral do SENAC nas décadas de 1960 e 1970, permaneceu na Instituição no período de 1950 a 1980 e comandou o Departamento Nacional do SENAC por mais duas décadas. 
Tornou-se necessário que o SENAC fizesse uma pequena e rápida reforma no prédio de apoio ao complexo Grande Hotel, transformando o anexo, que até então hospedava babás e motoristas dos hóspedes, em alojamento para estudantes, com uma estrutura maior para abrigar mais pessoas, visando o desenvolvimento dos cursos inicialmente implantados.

\subsection{Corpo discente: composição e perfil}

Investigamos o corpo discente do hotel-escola com o objetivo de definir o perfil das pessoas interessadas em buscar os cursos do SENAC de Águas de São Pedro.

No início da administração do SENAC no Grande Hotel de Águas de São Pedro, tornou-se necessário construir alojamento para os alunos que viessem buscar formação profissional no Hotel-Escola. Essa necessidade decorreu da dificuldade de se encontrar alunos interessados em cursar os programas de garçom e cozinheiro na cidade de Águas de São Pedro, onde o setor de serviços não era valorizado pelo mercado de trabalho na época. Havia também discriminação da profissão de garçom e cozinheiro, uma vez que não eram qualificações consideradas promissoras, além do fato de que os cursos eram desenvolvidos em Águas de São Pedro, localidade situada distante de São Paulo.

O SENAC já desenvolvia com sucesso, no restaurante "Lauro Cardoso de Almeida", na cidade de São Paulo, cursos de formação de cozinheiro e garçom. Havia demanda suficiente para os cursos de São Paulo, enquanto que em Águas de São Pedro a procura ficava aquém do número de vagas oferecidas pela Instituição à população. A Instituição SENAC encontrou duas razões para explicar a baixa demanda da procura dos cursos em Águas de São Pedro. A primeira, o fato de que os candidatos podiam ter a sua formação profissional na grande São Paulo, onde, na maioria, os jovens tinham residência junto da família. A segunda é que Águas de São Pedro caracterizava-se pelo seu isolamento, o aluno deveria morar por algum tempo ali, que sempre foi uma cidade acanhada e no interior do Estado São Paulo.

A implantação do curso de cozinheiro era preocupante porque atraía poucos candidatos por causa da baixa procura, e o curso sofria discriminação: a profissão de

\footnotetext{
${ }^{9}$ São chamados de básicos porque tem a função de oferecer informações condições práticas-operacionais para o profissional atual na área; além de exigir escolaridade básica, que é o ensino fundamental.
} 
cozinheiro era entendida pela maioria da população como uma atividade destinada às pessoas do sexo feminino e a profissão era pouco reconhecida pelo mercado de trabalho. Para sanar este problema, o SENAC determinou que todas as unidades do interior de São Paulo deveriam atender a uma meta pré-determinada pela sede do SENAC: deveriam encaminhar um determinado número de candidatos aos cursos básicos de Águas de São Pedro. Essa meta, segundo Manfrinato (2002), estava de acordo com o porte da cidade.

Segundo Manfrinato (2002), essa campanha junto às unidades não foi suficiente para alavancar os cursos básicos do SENAC de Águas de São Pedro. Diante disso, o SENAC passou a oferecer os seus cursos para internos da FEBEM e para jovens que juravam a bandeira nos tiros-de-guerra.

Como essas pessoas tinham baixo poder aquisitivo, o SENAC, além de oferecer moradia, alimentação, lavanderia, passou a beneficiar os alunos com ajuda de custo de meio salário mínimo. Com essas condições, aumentou a procura dos cursos básicos por pessoas desempregadas e pelos internos da FEBEM (MANFRINATO, 2002).

Segundo ainda a mesma autora, os alunos da FEBEM não tinham reincidências de crime; individuos que tinham possibilidade de recuperação para inserir-se novamente na sociedade. Bastava que tivessem uma oportunidade. O perfil dos alunos que vinham da FEBEM geralmente era de pessoas carentes, com baixa estima, sem comportamento ético para exercer uma profissão; mas tinham caráter, eram dignos, corretos e honestos. Muito diferentes, dos jovens da FEBEM de hoje (2006).

O SENAC tinha o cuidado de acrescentar aos seus programas questões fora do currículo para serem trabalhadas: questões técnicas envolvendo a profissionalização eram ministradas pedagogicamente. Existia uma preocupação do SENAC com o aprimoramento de aspectos comportamentais dos seus futuros profissionais.

A expressão saber-ser é utilizada para designar as qualidades pessoais que devem ser mobilizadas no trabalho para garantir maior produtividade e eficiência. O saber-ser compreende qualidades tais como ordem, método, precisão, rigor, polidez, autonomia, imaginação, iniciativa, adaptabilidade $e$ comunicabilidade(FIDALGO, 2000). 
Com essa finalidade, os cursos contavam com um trabalho de recuperação da auto-estima, da imagem pessoal e da convivência em grupo uma vez que estariam abraçando uma profissão que exige um trabalho em equipe, trabalhavam ainda assuntos relacionados à comunicação.

Os cursos básicos tiveram dentro do SENAC de Águas de São Pedro muitas funções, dentre elas a de alavancar o nome do Grande Hotel São Pedro.

Investigar qual era a intenção das propostas educacionais para o SENAC de Águas de São Pedro na formação na área de serviços, uma vez que a Instituição ampliou a sua oferta de cursos para o nível superior e de pós-graduação.

A mudança da oferta do nível dos cursos teve o objetivo de atender ao mercado de trabalho que estava cada vez mais exigente para com os profissionais de diversos níveis, o objetivo era formar profissionais de níveis superiores e de pós-graduação, suprindo a área de serviços, preparando profissionais para atuar em todos os níveis hierárquicos, do operacional ao gerente. Essa possibilidade não excluiu a continuidade de formação do nível técnico.

Buscando atender às necessidades de mercado acima mencionadas, o SENAC tentou atender por meio da diversificação dos seus cursos, os diversos níveis de formação profissional.

Durante a década de 1980 e até meados dos anos de 1990, o SENAC desenvolveu a filosofia acima mencionada. A partir de então começou a cobrar mensalidades dos cursos, a fim de buscar a sua auto-sustentabilidade, ou seja, a possibilidade de ser autônomo, e se tornar independente do repasse da verba dos comerciários. Percebe-se que o SENAC busca a sua permanência no mercado, com o objetivo de dar continuidade a um trabalho iniciado e estruturado por diversas décadas.

Segundo Manfrinato (2002), o governo do Estado cedeu ao SENAC as instalações do Grande Hotel, pois tinha por objetivo livrar-se dos hotéis sob o seu comando: eles só davam prejuízo e traziam problemas para administrar.

Ainda segundo a mesma autora, o SENAC tem uma dupla preocupação: formar o cidadão e fornecer a sua qualificação profissional. É uma das funções sociais do SENAC. Segundo Peterossi (1980)... A formação para o trabalho é diferente de educação formal, com características mais acadêmicas. 
O SENAC viveu um período difícil, quando da implantação dos seus cursos na cidade de Águas de São Pedro: eles precisavam ser implantados, estruturados e para uma clientela que tinha um perfil muito diferente dos moradores da cidade e com relação à Instituição, esse trabalho serviu como fundamento para a criação posterior do ensino superior, que hoje engrandece a cidade de Águas de São Pedro, uma vez a cidade é conhecida dentro e fora do Brasil, pois o SENAC mantém convênio com escolas de outros países, recebendo estrangeiros na cidade (MANFRINATO, 2002).

\subsubsection{Características atuais do corpo discente e do corpo docente do SENAC}

A seguir apresentamos o levantamento efetuado na unidade do SENAC referente ao ano de 2006 e que nos mostra o perfil do corpo discente, o qual esta no Apêndice A e do corpo docente, o qual esta no Apêndice B que compõem o curso de qualificação profissional de cozinheiro desenvolvido em Águas de São Pedro.

O objetivo desse levantamento ${ }^{10}$ das características do perfil da população que freqüenta o referido curso no SENAC de Águas de São Pedro é proporcionar ao leitor uma clareza da clientela do referido curso.

\subsubsection{Perfil do Corpo Docente do Curso de Cozinheiro}

\begin{tabular}{lcc}
\multicolumn{3}{c}{ Tabela 1 - Idade dos entrevistados } \\
\hline idade & f. absoluta & f. relativa \\
\hline $18-25$ anos & 2 & $50 \%$ \\
$26-34$ anos & 2 & $50 \%$ \\
Total & 4 & $100 \%$ \\
\hline \multicolumn{3}{c}{ Fonte: MANFRINATO, 2005}
\end{tabular}

A tabela 1 nos mostra que a metade da população docente é formada por pessoas jovens que abraçam a atividade com o objetivo de fazer carreira dentro da área, buscando o seu desenvolvimento profissional e o crescimento dentro da mesma, uma vez que é freqüentado por jovens que tem a possibilidade de se desenvolverem na 
profissão. A outra metade do corpo docente é formado por pessoas maduras que procuram firmar-se profissionalmente dentro da área em questão.

Tabela 2 - Sexo dos entrevistados

\begin{tabular}{lcc}
\hline \multicolumn{1}{c}{ sexo } & f. absoluta & f. relativa \\
\hline masculino & 4 & $100 \%$ \\
Total & 4 & $100 \%$ \\
\hline
\end{tabular}

Fonte: MANFRINATO, 2005

Como vimos no capitulo anterior a profissão de cozinheiro era "rotulada", como uma atividade eminentemente feminina, havendo preconceito no ingresso de homens na atividade, atualmente (2006) esse conceito mudou sofrendo uma alteração na nossa cultura tornando assim, o curso procurado por homens (Tabela 2) que buscam fazer da profissão uma carreira dentro da atividade que anteriormente marcada pelo sexo feminino.

Tabela 3 - Estado Civil dos entrevistados

\begin{tabular}{|c|c|c|}
\hline \multicolumn{3}{|c|}{ estado civil f. absoluta f. relativ } \\
\hline$\overline{\text { solteiro }}$ & 3 & $75 \%$ \\
\hline casado & 1 & $25 \%$ \\
\hline Total & 4 & $100 \%$ \\
\hline
\end{tabular}

Fonte: MANFRINATO, 2005

A tabela 3 nos mostra que as pessoas que ingressam e permanecem posteriormente na atividade são na sua maioria solteiras, com maior disponibilidade para atuar na atividade nos finais de semana e como docente poderem viajar em busca de conhecimento e de atividade extra-classe junto dos alunos.

\footnotetext{
${ }^{10}$ Pesquisa Preliminar para Identificação do Perfil do Aluno/Cliente do Centro de Educação de Turismo e Hotelaria de Águas de São Pedro e da Faculdade Senac de Turismo e Hotelaria de Águas de São Pedro - Grande Hotel São Pedro - Hotel Escola SENAC. Águas de São Pedro.
} 
Tabela 4 - Formação Escolar dos entrevistados

\begin{tabular}{lcc}
\hline \multicolumn{1}{c}{ formação escolar } & f. absoluta f. relativa \\
\hline Ensino fundamental completo & 1 & $25 \%$ \\
Ensino médio completo & 1 & $25 \%$ \\
Ensino superior incompleto & 1 & $25 \%$ \\
Ensino superior completo & 1 & $25 \%$ \\
Total & 4 & $100 \%$ \\
\hline
\end{tabular}

Fonte: MANFRINATO, 2005

O curso é composto por um grupo docente bastante heterogêneo com relação à escolaridade das pessoas envolvidas (Tabela 4), uma vez que os funcionários mais antigos ainda têm a sua formação escolar restrita apenas ao ensino fundamental, os demais vem buscando escolarizar-se trazendo assim um grande enriquecimento para o curso.

Esta busca de atualização dos professores mais jovens que formam o quadro docente do curso teve uma sensível mudança com a implantação do curso superior na área de hotelaria que tem a disciplina de gastronomia, com a implantação também do curso superior de gastronomia trazendo uma valorização para a área dentro do mercado de trabalho atual e o desenvolvimento docente desses profissionais dentro da própria instituição Senac e demais que tem na região como, por exemplo: a Universidade Metodista em Piracicaba - UNIMEP.

Tabela 5 - Profissão anterior ao curso

\begin{tabular}{lcc}
\hline & Profissão & f. absoluta f. relativa \\
\hline vendedor & 1 & $25 \%$ \\
estudante & 1 & $25 \%$ \\
cozinheiro & 1 & $25 \%$ \\
motorista & 1 & $25 \%$ \\
total & 4 & $100 \%$ \\
\hline
\end{tabular}

Fonte: MANFRINATO, 2005

Percebemos que houve um índice muito maior de pessoas que mudaram de profissão e se fixaram na atividade de cozinheiro (Tabela 5), julgamos tal ocorrência devido à necessidade dessas pessoas terem que começar a trabalhar cedo, uma vez que vem de famílias simples. 
Entretanto o conceito dentro da profissão de cozinheiro vem se alterando sensivelmente, pois a profissão cada vez mais tem sido procurada por grandes empresários e por pessoas de poder aquisitivo elevado, uma vez que tal atividade se firmou dentro do mercado de trabalho como rendosa e com inúmeras exigências, tais como conhecimento de outros idiomas, o conhecimento de outras culturas fora do país, o acesso a iguarias finas, caras e muitas vezes estrangeiras.

\begin{tabular}{lcc} 
Tabela 6 - Local de Residência dos entrevistados \\
\cline { 2 - 2 } Local de residência & f. absoluta f. relativa \\
\hline São Pedro & 2 & $50 \%$ \\
Águas de São Pedro & 2 & $50 \%$ \\
Total & 4 & $100 \%$ \\
\hline
\end{tabular}

Fonte: MANFRINATO, 2005

A residência dos professores está dividida em pessoas que moram em Águas de São Pedro, uma vez que o hotel localiza-se no município, entretanto a preferência das pessoas é a de residir em São Pedro (Tabela 6). Esta cidade tem uma estrutura médica melhor, comércio com maior oferta e com preços melhores, já que ela não atende na sua maioria os turistas, como é o caso de Águas de São Pedro. O município em questão também oferece maior opção de casas de diversos portes, já a cidade de Águas de São Pedro, por ter na sua maioria casas de veraneio, é formada pela maioria casas de grande porte.

Tabela 7 - Perspectiva de emprego dentro da área gastronômica

\begin{tabular}{lcc}
\hline \multicolumn{1}{c}{ Perspectiva de emprego } & f. absoluta f. relativa \\
\hline Chefia cozinha & 1 & $25 \%$ \\
Docência em curso superior & 1 & $25 \%$ \\
Docência & 2 & $50 \%$ \\
Total & 4 & $100 \%$ \\
\hline
\end{tabular}

Fonte: MANFRINATO, 2005

Percebemos que os professores objetivam um crescimento dentro da área de atuação e que a maioria deles pensa em se fixar na área docente. Embora dentre aqueles que tenham mencionado a chefia da cozinha, não está excluído da área docente, uma 
vez que os chefes atuam em sala de aula, seja com aula teóricas ou práticas dentro do hotel-escola (Tabela 7).

\subsubsection{Perfil do Corpo Discente do Curso de Cozinheiro}

\begin{tabular}{ccc}
\multicolumn{3}{c}{ Tabela 8 - Idade dos entrevistados } \\
\hline idade & f. absoluta f. relativa \\
\hline $18-25$ anos & 6 & $46,2 \%$ \\
$35-50$ anos & 4 & $30,8 \%$ \\
$26-34$ anos & 3 & $23,1 \%$ \\
Total & 13 & $100 \%$ \\
\hline \multicolumn{3}{c}{ Fonte: MANFRINATO, 2005}
\end{tabular}

A tabela 8 nos mostra que a metade da população discente é formada por pessoas jovens que abraçam a atividade com o objetivo de fazer carreira dentro da área, buscando o seu desenvolvimento profissional e o crescimento dentro da mesma. A segunda demanda de pessoas se iguala a terceira que é formada por aqueles que buscam uma colocação no mercado de trabalho, mas que desfrutam de uma idade madura, essas pessoas na maioria das vezes, já tinham uma colocação no mercado de trabalho, mas não foram bem sucedidas buscando assim uma recolocação.

Tabela 9 - Sexo dos entrevistados

\begin{tabular}{lcc}
\hline sexo & f. absoluta & f. relativa \\
\hline masculino & 13 & $100 \%$ \\
Total & 13 & $100 \%$ \\
\hline \multicolumn{3}{l}{ Fonte: } \\
\hline
\end{tabular}

Segundo os dados da tabela 9, percebemos que há uma nova cultura da atuação do sexo masculino com relação à profissão em questão. 
Tabela 10 - Estado Civil dos entrevistados

\begin{tabular}{|c|c|c|}
\hline \multicolumn{3}{|c|}{ estado civil f. absoluta f. relativa } \\
\hline$\overline{\text { solteiro }}$ & 9 & $69,2 \%$ \\
\hline casado & 4 & $30,8 \%$ \\
\hline Total & 13 & $100 \%$ \\
\hline
\end{tabular}

Fonte: MANFRINATO, 2005

A tabela 10 nos mostra que as pessoas que buscam o curso é na maioria solteira, com maior disponibilidade e que buscam uma colocação no mercado de trabalho a partir da profissionalização dentro da área gastronômica.

Tabela 11 - Formação Escolar dos entrevistados

\begin{tabular}{lcc}
\hline \multicolumn{1}{c}{ formação escolar } & f. absoluta f. relativa \\
\hline Ensino médio completo & 11 & $84,6 \%$ \\
Ensino médio incompleto & 1 & $7,7 \%$ \\
Ensino superior incompleto & 1 & $7,7 \%$ \\
Total & 13 & $100 \%$ \\
\hline
\end{tabular}

Fonte: MANFRINATO, 2005

Os dados anteriores (Tabela 11) são bastante animadores, uma vez que apenas uma pessoa tem o ensino médio incompleto, sendo que as demais buscam, uma continuidade de cursos objetivando a profissionalização destes.

O que demonstra que o perfil dos alunos que buscavam o curso mudou, pois deixou de ser aquele aluno carente, como vimos nos capítulos anteriores e passou a ser aquele que quer atuar na profissão em níveis estratégicos dentro da área a partir da sua formação escolar, nas busca de níveis superiores de ensino. 
Tabela 12 - Profissão anterior ao curso

\begin{tabular}{lcc}
\hline \multicolumn{1}{c}{ Profissão } & f. absoluta f. relativa \\
\hline Vendas & 2 & $15,4 \%$ \\
Cozinheiro & 1 & $7,7 \%$ \\
Auxiliar de stward & 1 & $7,7 \%$ \\
Crediarista & 1 & $7,7 \%$ \\
Garçom ou bartender & 2 & $15,4 \%$ \\
Gerente e administrador de & 1 & $7,7 \%$ \\
empresa & & \\
Recepcionista de hotel & 1 & $7,7 \%$ \\
Costureiro & 1 & $7,7 \%$ \\
Ajudante de confeiteiro & 1 & $7,7 \%$ \\
Ajudante de cozinha & 1 & $7,7 \%$ \\
Decorador de imóvel & 1 & $7,7 \%$ \\
Total & 13 & $100 \%$ \\
\hline
\end{tabular}

Fonte: MANFRINATO, 2005

A clientela do curso que busca a gastronomia como atuação sempre esteve ligada a área de trabalho em equipe, tendo como pré-requisito a relação interpessoal uma vez que a maioria sempre atuou na área de serviços (Tabela 12).

\begin{tabular}{lcc} 
Tabela 13 - Local de Residência dos entrevistadodo \\
\cline { 2 - 3 } Local de residência & f. absoluta f. relativa \\
\hline Interior de São Paulo & 2 & $15,4 \%$ \\
São Pedro & 5 & $38,5 \%$ \\
Águas de São Pedro & 2 & $15,4 \%$ \\
Grande São Paulo & 2 & $15,4 \%$ \\
Litoral de São Paulo & 1 & $7,7 \%$ \\
Outro Estado & 1 & $7,7 \%$ \\
Total & 13 & $100 \%$ \\
\hline
\end{tabular}

Fonte: MANFRINATO, 2005

A cidade de São Pedro e região nunca aderiram o curso como uma possibilidade de atuação profissional, uma vez que a muito tempo atrás criou-se na região um ranço com relação ao curso, que conforme mencionado anteriormente o perfil da clientela era diferente. Atualmente esse conceito mudou na cidade e região e a evidencia disso é o índice de pessoas da cidade que buscam o curso (Tabela 13). 
Tabela 14 - Perspectiva de emprego dentro da área gastronômica

\begin{tabular}{lcc}
\hline Perspectiva de emprego & f. absoluta f. relativa \\
\hline Confeitaria & 2 & $15 \%$ \\
Garde Manger & 1 & $8 \%$ \\
Panificação & 1 & $8 \%$ \\
Cozinha Quente & 10 & $77 \%$ \\
Cozinha de navio & 1 & $8 \%$ \\
Não respondeu & 1 & $8 \%$ \\
Total & 13 & $100 \%$ \\
\hline
\end{tabular}

Fonte: MANFRINATO, 2005

Dentro da área gastronômica, os profissionais afirmam que todas as áreas são independentes, ou seja, embora elas tenham interligação no dia-a-dia, porque uma atua em função da outra e para um mesmo objetivo, os departamentos são tão complexos que tem um universo muito particular de informações técnicas, assim o aluno deve atuar em todas as áreas visando a busca daquele setor que mais se identifique a fim de se profissionalizar dentro da área escolhida (Tabela 14).

Para facilitar o entendimento do leitor esclarecemos que a soma das porcentagens nessa última tabela é maior que $100 \%$ pois as pessoas puderam responder livremente mais de uma opção da escolha da sua área de atuação. A razão pela qual deixamos livre que o aluno optasse por mais de uma se deu devido àqueles que ainda estão definindo a sua área de atuação futura. 


\section{A IMPORTÂNCIA DA INSERÇÃO DA EDUCAÇÃO AMBIENTAL NO ENSINO TÉCNICO}

Segundo NASCIMENTO E CAMARGO (2002) o meio ambiente deixou de ser um tema exclusivo de ambientalistas e cientistas que se interessam pelo assunto, para se tornar o foco de atenção da sociedade mundial.

Considerando o panorama que se apresenta e devido aos efeitos das transformações tecnológicas e da nova ordem econômica mundial, o SENAC desenvolveu um novo modelo pedagógico cujo objetivo é o redirecionamento da formação profissional (WAEHNELDT, 2003).

A qualificação técnica profissional deve ser estruturada a partir da construção empírica e fundamentada em análises dos requisitos e competências de ações que sejam emergentes para a sociedade (PEREZ, 2003).

Segundo (WAEHNELDT, 2003) o modelo pedagógico da formação profissional técnica do SENAC visa a educação ambiental globalizadora do aluno, não apenas enquanto futuro profissional, mas principalmente, como cidadão no exercício dos seus direitos junto a um meio ambiente preservado e a condições satisfatórias de trabalho, tanto do ponto de vista de sua segurança ocupacional, quanto de seus direitos trabalhistas.

O meio ambiente entre o final dos anos 60 e início dos anos 70 passou a estar em evidência para uma pequena minoria que se preocupava com a natureza e que difundia um alerta contra o esgotamento de recursos naturais.

$\mathrm{Na}$ década de 80 o mundo se volta para atividades relacionadas ao meio ambiente através da educação ambiental, que surgiu como um termo difundido no planeta, tornando-se imprescindível nos espaços escolares, empresariais, de lazer, dentre outros (GUIMARÃES, 1995).

Segundo DALMÁS (1998), a atual crise mundial desperta nas pessoas a necessidade de uma virada epistemológica, exigindo, assim, reflexão e novas medidas 
através da produção de conhecimento, da relação de bens e consumo, buscando atrelar nessas ações o maior número de pessoas, com o objetivo de repensar os conhecimentos.

A educação ambiental é a construção do conhecimento na prática do diaa-dia, que se realiza através de um processo educativo contínuo, e exige a prática diária de atenção voltada às questões ambientais, uma vez que a formação profisssional deve preparar os aprendizes para o desenvolvimento técnico competente, mas primeiramente para o desempenho profissional consciente, pautado em ética e cidadania.

Nas diversas áreas de formação profissional e nas questões relacionadas ao meio ambiente, educação, sociedade e trabalho há diversas vertentes para se trabalhar a educação ambiental, dentro dos currículos propostos para as diferentes áreas de formação dos cursos técnicos profissionalizantes (WAEHNELDT, 2003).

Perez (2003) pensou a formação técnica profissional como algo que leva os aprendizes a buscar uma forma operativa, de maneira que se estabelecesse um ciclo composto da seguinte dinâmica: ação - capacitação - reflexão, sendo essas três chaves munidas de princípios fundamentais no sentido de ordem e direção, levando o aluno ou melhor, o futuro profissional - a atuar dentro da sua área de formação de forma reflexiva e voltada para questões relevantes à sua profissão e ao contexto do mundo que o cerca (no caso as questões relevância ao meio ambiente).

Segundo a autora acima mencionada, os cursos oferecidos nas áreas de saúde, turismo, hotelaria e administração, podem perceber a riqueza de possibilidades da relação entre o meio ambiente e as ocupações profissionais agrupadas em cada uma dessas áreas de atuação, algo que pode ser observado também na escola SENAC.

O ser humano vai se desintegrando cada vez mais da natureza como se não fizesse parte dela, deixando cada vez mais à parte as relações de equilíbrio com a mesma, como se houvesse uma separação: ser humano - natureza.

Os profissionais devem ter sua formação profissional pautada em uma nova ética nas relações sociais e estas com a natureza, visando muito mais do que atitudes pautadas em discursos ou frases do tipo: "ecologicamente corretas" ou "reciclagem de lixo", mas um enfoque centrado no ser humano como parte da natureza de maneira que este busque um equilíbrio do meio ambiente, obtendo como resultado melhor qualidade de vida. 
Segundo FONTES (2003):

A educação ambiental no/pelo ambiente pode corresponder à educação pela acção porque esta forma de educação ambiental exige acção pelos aprendizes no ambiente. De mesma forma, a educação para o ambiente exige acção pelos aprendizes para, ou favor de o ambiente; pode ser considerada educação para a acção e que, através desta acção, se torna educação para o ambiente.

Neste caso, se busca a ação no ambiente através da informação e compreensão dessas informações - ou seja, uma mudança de comportamento do aluno/aprendiz, procura ainda, um ambiente de qualidade e uma mudança de ambiente (FONTES, 2003).

Dessa forma, a educação sobre o ambiente e educação no/pelo ambiente, está articulada na ação, e quando a ação é incorporada pelo corpo discente, docente e todos os membros da escola, agindo como pessoas que contribuem para o processo da ação, há uma mudança eficaz no ambiente da comunidade escolar, uma vez que todos participaram do processo de mudança e de reestruturação da ação.

As escolas tratam a problemática ambiental como sendo um tema global e multidimensional, em que a questão ambiental é vista de forma isolada de um contexto sistêmico (NOAL, 2003).

A transformação de conhecimento com a preocupação ambiental vai muito além da incorporação de componentes e conteúdos ecológicos que se adaptam às exigências da Legislação, uma vez que o saber ambiental não é um novo setor do conhecimento ou uma nova disciplina, e sim a problemática de todas as disciplinas e de todos os níveis do sistema educativo (LEFF, 1997).

Como cita FONTES (2003), trata-se de uma educação pela ação ambiental, educação verdadeira e verdadeiramente para o ambiente e educação para a competência para a ação.

A educação tradicional é vista como uma formação voltada para ações mecanicistas, principalmente a formação profissional-operacional, à qual se destinam os cursos técnicos.

A formação mecanicista ou cartesiana se pauta em uma formação simplista e na redução dos fenômenos complexos da realidade, visando a superação das dicotomias entre o conhecimento e a ação, entre o sujeito e o objeto, entre a ciência e a sociedade, 
ressaltando os determinantes sócio-históricos da produção do conhecimento científico e o papel da ciência na divisão social do trabalho. (GUIMARÃES, 2004).

A formação profissional deve estar atenta a preparar o profissional para ingressar no mercado de trabalho, de tal forma que este adquira conhecimento integral e atrelado à totalidade e pautado em ações locais com reflexos globais (GUIMARÃES, 1995).

O conhecimento não deve estar atrelado à formação fragmentada, desassociada dos contextos planetários, e sim à integração de várias áreas do saber, e embasado na prática diária.

Assim, planejar ações em educação ambiental deve ter como premissa a inserção da participação de todos na busca de uma integração das diversas áreas do conhecimento.

Segundo LEFF (1997), a formação ambiental questiona os métodos tradicionais de ensino, sugerindo novos métodos de transmissão do saber, nos quais esteja presente uma estreita relação entre a pesquisa, a docência, a difusão e extensão do saber. Assim, a educação ambiental estabelece novas atitudes entre professores e alunos e novas relações sociais para a produção do saber ambiental e novas formas de inclusão de práticas pedagógicas.

Segundo SANTOS E SATO (2003) a formação profisssional deve ter o seu rol de disciplinas atrelado à questão ambiental, pois é uma forma de ampliar a grade curricular, não se restringindo somente às questões técnicas, mas também com preocupação de incorporar questões referentes aos recursos naturais.

A situação mundial atual é tão grave que há urgência na implantação de programas de educação ambiental dentro e fora da educação formal, em particular naquelas que preparam o jovem para atuar diretamente no mercado de trabalho; de maneira que o futuro profissional possa formar novos valores e atitudes, adquirindo uma relação harmoniosa com a natureza, pautada no equilíbrio e na transformação do atual cenário do ambiente natural do mundo.

Segundo Guimarães (1995), a escola deve preparar programas de educação ambiental de ordem prática e concreta, de maneira que os alunos possam visualizar a metodologia, dentro de um processo de aprendizagem, através de atitudes racionais, novos hábitos, responsáveis e solidários.

Os docentes que atuam na área de formação profissional preparam profissionais que estarão atuando diretamente no mercado de trabalho, vivenciando diretamente na prática cotidiana as questões relacionadas ao meio ambiente. 
O ensino técnico profissionalizante tem sensibilizado os profissionais em formação para diversas questões, como por exemplo o lixo - que tem se tornado uma das maiores preocupações em relação ao meio ambiente e a qualidade de vida - e o consumismo, que visa à mudança de hábitos de descarte e consumo na relação meio ambiente/lixo, uma vez que a maior parte do lixo brasileiro é composta de lixo orgânico, ou seja, de resto de alimentos. Esse fato traz à tona um dos maiores problemas da sociedade de consumo: a má utilização dos recursos alimentares e seu conseqüente desperdício, objetivando, então, a valorização do aproveitamento integral dos alimentos (WAEHNELDT, 2003).

Em algumas situações os professores não conseguem ir além de uma proposta de educação, mesmo quando são sensibilizados e motivados a inserir o tema em questão em suas práticas educativas, e acabam mobilizados por práticas conservadoras de educação (GUIMARÃES, 2004).

Em relação ao ensino técnico, nosso objeto de pesquisa, a afirmação do autor acima se reproduz com maior evidência, uma vez que o conteúdo é estritamente técnico e a atividade, na maioria das vezes, é prática/operacional, o que dificulta uma visão macro dos assuntos correlatos que poderiam enriquecer e complementar a aula - no caso os temas transversais e, dentro dele, em especial, a educação ambiental.

A alteração que se pretende estabelecer através da educação ambiental traz à humanidade uma nova ética com a reavaliação de valores sociais, em que se busca uma sociedade equilibrada, pautada em valores de inserção social, em que a miséria é um problema geral, ou seja, diz respeito a todas as pessoas, independentemente da condição social, financeira, cultural, e busca alcançar um consumo equilibrado, desconsiderando o consumismo.

Afirma, ainda, GUIMARÃES (1995) que a educação ambiental deve estar associada a uma atitude reflexiva, vinculando a ação, a teoria e a prática, o pensar e o fazer para que a reflexão não se imobilize sem ação e para que esta gere um ativismo, uma possibilidade de mudança.

$\mathrm{O}$ autor acima continua refletindo na função de que a educação ambiental tem uma função ampla, atingindo níveis em que a relação do ser humano seja integrada à sociedade, e esta, por sua vez, seja voltada para a natureza, visando como resultado final o equilíbrio local e global, obtendo como resultado a qualidade de vida para todos. 
A reflexão nos remete a pensar, a aprender a aprender, a aprender a pensar, à não aceitação da submissão e à busca da consciência e da autonomia diante dos fatos e das situações.

Segundo ALARCÃO (1996) refletir para agir autonomamente parece ser uma das expressões-chave no contexto educativo internacional deste final de século XX e inicio do século XXI.

Para DEWEY (1933) citado por ALARCÃO (1996), a reflexão é uma forma especializada de pensar, e baseia-se no pensamento, em atitudes de questionamento e curiosidade.

O professor que atua no ensino técnico é um professor prático acima de tudo, pois na maioria das vezes não restringe a sua prática profissional à sala de aula convencional, mas atua principalmente nos laboratórios; e, uma vez que o aluno aprende praticando, pode refletir sobre o que ele "faz", ou seja, sobre a sua atividade, sua ação. O professor desenvolve, dessa forma, no aluno, a capacidade de pensar, de construir o seu saber, a partir da reflexão sobre a sua prática, na capacidade de gerir a sua aprendizagem, de ser autônomo.

Segundo ALARCÃO (1996), quanto maior a capacidade de reflexão, maior a capacidade de autonomização.

Assim, quando o professor conduz o aluno à reflexão e esta à autonomia, é possível que este futuro profissional busque constantemente a reconstrução, que deve estar atrelada à responsabilidade, ao amadurecimento profissional e à capacidade de tomar decisões dentro da atuação profissional de cada indivíduo.

Para HOLEC (1979) citado por ALARCÃO (1996), o conceito de aprendizagem/autonomia é a capacidade para gerir a própria aprendizagem, o que implica em ser capaz de definir objetivos pessoais, organizar e gerir tempos e espaços, se auto-avaliar, e avaliar os processos, controlar ritmos, conteúdos e tarefas, além de despertar no aluno a autonomia na aprendizagem, de maneira a formar um profissional autônomo, que se reconstrói constantemente, absorvendo experiências anteriormente vivenciadas, consciente de que o seu papel profissional possa, de forma responsável, gerar benefícios à sociedade em que vivemos.

O curso técnico-profissionalizante busca formar profissionais que, na maioria das vezes, vão atuar de forma operacional e prática no mercado de trabalho. Não podemos subestimar a capacidade desses profissionais, adestrando-os. O papel do educador é conduzir o aluno a refletir sobre sua ação, a compreender seus saberes 
teóricos aplicados à prática profissional, de forma que o saber faça sentido sobre a ação, resultando, assim, na prática em aprofundamento do conhecimento e como conseqüência a ação.

A interação teoria/prática no mundo profissional são valores estabelecidos entre o saber documental e o saber experiencial, que através da reflexão conduzem ao desenvolvimento da competência profissional (ALARCÃO, 1996).

Assim, o professor do ensino técnico tem que estar preocupado em despertar em seu aluno a necessidade de desenvolver a capacidade de construir o seu conhecimento constantemente, na busca do saber pensar, pois a educação não se esgota, e sim é um processo de transformação do ser humano.

Segundo DEMO (1998) as máquinas abstratas (computadores) não substituem o papel do professor, uma vez que o primeiro atua como transmissor de conhecimento e o segundo como um facilitador da construção do conhecimento.

Segundo o mesmo autor, a educação torna-se estratégia principal da identidade cultural, porque engloba a inovação como serviço à sociedade, sobretudo para as novas gerações, para que a construção do conhecimento seja um compromisso coletivo, pautado muito mais no qualitativo.

A educação que os professores do ensino técnico devem buscar deve ser pautada no conhecimento teórico e prático, o desenvolvimento da cidadania, composta de profissionais críticos, criativos, autônomos e reflexivos.

O papel do professor é, além de pesquisar, orientar o seu aluno a desenvolver a capacidade de construir e de participar do processo de aprendizagem, propiciando-lhe dar a sua contribuição, e estimulando-o na construção do conhecimento e no exercício de cidadania, uma vez que a educação não se reduz somente ao conhecimento.

Segundo WAEHNELDT (2003) o desenvolvimento da temática de educação ambiental voltada para o ensino técnico-profissionalizante tornou-se viável no SENAC devido ao processo de revisão das ações formativas, desde o ano de 1993. Esse processo possibilita a ampliação dos objetivos e a remodelação da formatação de metodologias da formação profissional, viabilizando a aplicação da educação ambiental nos programas dos cursos oferecidos por esta instituição.

A educação ambiental como proposta pedagógica de participação, interdisciplinaridade e conhecimento sistêmico propõe ações articuladas.

$\mathrm{Na}$ escola, a educação ambiental é uma temática que vem sendo discutida há bastante tempo, mas nossa experiência como educadores aponta a necessidade de ainda 
investirmos nesta área, com o objetivo de ampliar os horizontes daqueles que já experenciaram as práticas de educação ambiental na escola, e estimular aqueles que ainda não tiveram oportunidades.

Assim, propusemos a reflexão e o aprofundamento da inserção da educação ambiental dentro do desenvolvimento pedagógico do curso de cozinheiro, o qual está inserido na área de hotelaria, diretamente relacionado ao campo da prestação de serviço.

A área de hotelaria é composta de sub-áreas que favorecem as diversas formações profissionais, de maneira que eles possam atuar dentro da área de serviços. Estas sub-áreas são nichos de mercado e formam a macro área de hospitalidade, que é formada pelos seguintes campos de atuação: lazer, eventos, hospedagem, ecoturismo, recursos humanos, administração e gestão, elaboração de cardápio, restaurantes comerciais, coquetelaria, sommelier, cambuza, flats, marketing, banquetes, gastronomia, manipulação de alimentos, segurança, lavanderia, setor de controladoria, restaurante de coletividade, restaurante internacional, restaurante executivo, cerimonial de eventos, etiqueta de eventos, etiqueta à mesa e outros.

Os paradigmas e o reflexo da educação ambiental, juntamente à interação entre as diversas ciências e as ciências naturais, propõem princípios teórico-metodológicos como a sustentabilidade, a complexidade, a interdisciplinaridade e a transdisciplinaridade. Estes são os principais desafios da educação ambiental na formação de professores e em sua inserção em diferentes espaços de formação, de troca do saber.

Assim, os encontros que deverão resultar no servirão de objeto para a nossa pesquisa, com os professores do curso de cozinheiro, que está inserido no curso técnico de formação profissional, o qual faz parte da sub-área de gastronomia que compõe a área de hotelaria.

A formação profissional do curso de cozinheiro tem a carga horária estabelecida de 1044 horas, num período de seis (06) meses, e é composta por três (03) etapas. Faz parte do programa denominado de "fase" de progressão do aluno.

Segundo WAEHNELDT (2003), o curso de formação profissional voltado para turismo e hotelaria ganha uma importância especial em relação ao meio ambiente, uma vez que esta questão permeia todos os conteúdos da área de turismo e hotelaria, e a gastronomia aparece como uma sub-área voltada para essas áreas macro, apresentando grande relevância nas questões do meio ambiente. 
Ainda segundo a mesma autora, os objetivos do SENAC no que diz respeito à educação ambiental tornam-se viáveis na medida em que a formação profissional dos alunos está vinculada a uma consciência de novas atitudes quanto à problemática ambiental na atual proposta pedagógica desta instituição.

Segundo BOHM (2002), o maior desafio dos cursos técnicos de formação profissional está em estabelecer a inserção de temas ambientais nas grades curriculares, uma vez que o curso comumente já tem características que englobam a formação profissional, não somente voltadas para questões técnicas, mas também para a formação de cidadãos capazes de refletir sobre os problemas conexos à sua realidade planetária.

Dessa forma, os programas do SENAC assumem a tarefa complexa de basear todas as ações práticas através da educação ambiental, objetivando o principio ético que visa à efetividade de mudanças de mentalidades acerca da relação sociedade/meio ambiente (WAEHNELDT, 2003).

Os programas dos cursos de formação técnica/profissionalizante do SENAC buscam garantir a construção de uma visão prospectiva da educação ambiental e suas finalidades - visão esta que poderá levar à criação de novos projetos que destaquem sempre a multiplicidade de inter-relações que nossa sociedade mantém com o meio ambiente (WAEHNELDT, 2003).

O currículo do curso deve estar voltado para as necessidades globais que se apresentam, considerando-se a formação de pensamento complexo, multidimensional e interligado, de forma a obter um compromisso com a transformação da sociedade em relação não somente à ela mesma, mas também à natureza e à formação profissional do aluno.

A grade curricular de um curso é um documento que busca resultados na formação profissional dos aprendizes, alinhavada às atitudes concretas do dia-a-dia, favorecendo a incorporação de elementos necessários para a inclusão das questões ambientais na formação profissional dos alunos.

A formação curricular deve buscar integrar novos conhecimentos, considerandose questões que envolvam o psicológico, o social, ético, econômico e o ecológico, de forma que esses novos profissionais se situem num mundo tão complexo quanto o nosso (de educadores) e que possam trabalhar com as informações dentro de um contexto amplo, estabelecendo uma relação entre as partes, tendo a visão e a informação do todo. 
Segundo FREITAS (2003) o ensino/aprendizagem deve incorporar uma perspectiva ambiental de forma a entender os conceitos desta, e a incorporar na grade curricular para atender a uma demanda social.

A grade curricular deve ter sua validade dentro da cultura da sociedade em que está inserida, considerando-se a idéia de indivíduo e de sociedade sustentável, de tal forma que o currículo busque superar a distância que existe entre a escola e a realidade de mundo, buscando alcançar conteúdos curriculares alternativos, melhorias na formação dos docentes e desenvolvimento de conteúdos curriculares (FREITAS, 2003).

Segundo FREITAS (2003) um currículo que se paute em diversas vertentes e em especial na do meio ambiente, demonstra a necessidade de "compromisso" das disciplinas com a transformação das relações da sociedade com a natureza e o desenvolvimento de reflexões e condutas que gerem a transformação de ações cotidianas e no meio social e natural.

É necessário buscar intervenções na grade curricular de forma que os professores, através das disciplinas, estejam engajados e comprometidos na contribuição para a formação de profissionais com condutas reflexivas e críticas, tendo como objetivo final o desenvolvimento de pessoas voltadas para o desempenho da cidadania.

As situações de ensino e aprendizagem são bem diversificadas e podem atingir as diferentes necessidades dos indivíduos. Em algumas disciplinas são trabalhados textos, leituras complementares, vídeos e palestras.

Os professores que desenvolvem dentro das suas disciplinas reflexões sobre o meio ambiente, oportunizam situações do cotidiano, e viabilizam uma forma de aprofundamento das questões de extrema relevância para área de atuação do curso, além de propiciarem, também, o rompimento de uma visão estática dos conteúdos assimilados. Embora reflexão seja de extrema importância para formação do futuro profissional, não é formalmente registrada.

Os temas transversais são produtos resultantes do avanço das idéias ao longo da história. Assim, é natural que os avanços reflitam no ensino e que o aluno esteja em sintonia com o aparecimento de temas que transitem entre as diversas disciplinas que compõem a grade curricular dos cursos. Tais temas levam os alunos a refletirem sobre direitos e oportunidades entre homens e mulheres, preservação e melhoria do meio ambiente, temas relativos à sexualidade e efetividade, relações interpessoais, formação de pessoas com espírito crítico e criativo, formação de uma sociedade equilibrada e justa, qualidade de vida, dentre outras. 
O objetivo é introduzir no ensino assuntos que desenvolvam a criticidade, de tal forma que o aluno esteja em sintonia com os problemas do planeta e tenha o compromisso de contribuir para mudar o cenário, de forma crítica e criativa, incorporando a necessidade de atuar frente às dificuldades do seu bairro, da sua cidade, mas cientes de que podem fazer algo também no contexto global.

É necessário que o educador se conscientize das preocupações mais perspicazes da sociedade atual, de forma que não se faça necessário o deslocamento de matérias curriculares, e sim da adequação de seus conteúdos, não somente na formação de valores, mas também no sentido de agregar informações para que os alunos construam novos valores. Assim, os temas transversais não atuam desassociados dos conteúdos, mas de forma a beneficiar o programa já pré-determinado.

A proposta dos novos temas associados aos conteúdos curriculares propõe novos valores e inovação de procedimentos e metodologias de ensino, que demandarão em uma nova mudança de perspectiva.

Segundo WAEHNELDT (2003), em um contexto em que a associação entre ecologia e mercado - incluindo aí o campo do comércio e dos serviços - é cada vez mais presente, as escolas voltadas para formação profissional estão sendo cada vez mais estimuladas de forma natural a incluir a questão ambiental em suas grades curriculares e dinâmicas de ensino.

As disciplinas são desenvolvidas de forma interdisciplinar, o que propicia a troca de saberes entre as diferentes áreas do conhecimento, não se restringindo à formação profissional de cozinheiro, mas buscando a formação de um profissional que deverá voltar-se para o mercado de trabalho (que por sua vez tem exigências que vão além dos conhecimentos técnicos), para o desenvolvimento da atividade profissional.

O curso em sua atividade prática propicia o desenvolvimento de situações reais do cotidiano da profissão e a oportunidade de vivências do aprofundamento de questões relativas ao meio ambiente, promovendo o desenvolvimento de atividades concretas e a troca de saberes entre diferentes áreas do conhecimento, propiciando a criatividade em busca de interpretações que visem a otimização do uso dos recursos naturais dentro do espaço profissional.

O cozinheiro deve ter em sua formação profissional uma reflexão voltada para a qualidade de vida das pessoas, uma vez que busca executar uma atividade que objetiva a satisfação, o bem estar e o desenvolvimento de atividades na prestação de serviço. 
Segundo FONTES (2003) a aprendizagem em relação à ação ambiental é composta de quatro situações:

- Autenticidade, em que o aprendiz transfira o conhecimento adquirido dentro do seu universo de atuação;

- Concretização da situação, em que o aprendiz coloque em prática dentro do seu trabalho cotidiano, o aprendizado adquirido;

- Contextos e perspectivas múltiplas, em que o conhecimento adquirido possa ser aplicado em situações problemáticas do trabalho;

- Contextos sociais, onde haja integração e cooperação entre o aprendiz e a comunidade local.

Assim, a inserção de novos conhecimentos, de forma intrínseca na atividade prática profissional e no conhecimento teórico do aluno, propicia a sensibilização dos diversos grupos sociais quanto à importância de se construir novos valores e de se adotar uma postura ética e solidária em relação ao meio ambiente. A adoção de uma nova postura valoriza o exercício de cidadania, e deve gerar novas atitudes que estejam voltadas para a proteção ambiental (WAHNELDT, 2003). 


\section{PROCEDIMENTOS METODOLÓGICOS ${ }^{11}$}

\subsection{Pesquisa qualitativa}

A metodologia que foi trabalhada na nossa pesquisa buscou embasar-se na pesquisa qualitativa, uma vez que analisamos o curso de cozinheiro, o qual faz parte do universo da gastronomia, sendo que este se situa dentro do curso de hotelaria na formação técnica de profissionais.

A pesquisa qualitativa implica no contato direto do local e das circunstâncias da investigação em que a coordenação, professores e alunos entrevistados interagem e atuam como fonte direta dos dados obtidos, em que o pesquisador é o principal instrumento dentro do processo de realização e análise da pesquisa.

A pesquisa qualitativa tem uma característica particular, que é "o ambiente" onde ela ocorre. O pesquisador está no local onde ela é desenvolvida e, portanto pode fazer uma análise do cotidiano do lugar pesquisado, enriquecendo com isso a pesquisa. Assim, pudemos observar e participar do curso na escola SENAC, bem como interagir com os alunos, sem alterar o cotidiano do local.

Durante a pesquisa tomamos o cuidado de não intervir no ambiente estudado, de forma que os alunos agissem e participassem de forma natural, sem qualquer manipulação intencional da nossa parte.

A nossa pesquisa buscou levantar também, documentos que pudessem evidenciar situações de sala de aula, tais como: plano de ensino, grade curricular das atividades práticas operacionais do curso, atividades teóricas que contém informações ricas que evidenciam as descrições de situações e procedimentos; além de questionários

${ }^{11}$ Fonte: Lüdke e André (1986). 
aplicados que buscam retratar a realidade, e que são considerados importantes para contextualizar a descrição da realidade pesquisada.

Uma característica relevante na análise qualitativa é o "processo", ou seja, o contexto de análise local e cotidiana do lugar pesquisado. Nesse contexto foram analisadas as atividades, os procedimentos e o cotidiano. Estes itens estão muito presentes dentro do tipo de análise da pesquisa, na qual o produto final é apenas conseqüência dos dados obtidos durante todo o processo da pesquisa.

Segundo ANDRÉ (1995), a pesquisa qualitativa esta intimamente ligada à etnometodologia, que é a corrente da sociologia que vai influenciar a abordagem qualitativa da pesquisa.

Etnometodologia é o estudo de como os indivíduos compreendem e estruturam o seu dia-a-dia, ou seja, o pesquisador procura descobrir "os métodos" que as pessoas usam em seu cotidiano para entender e construir a realidade que as cerca.

Baseando-se nessas teorias, o nosso centro de interesse durante a pesquisa no hotel-escola SENAC foi centrado nos conhecimentos tácitos, nas formas de entendimento do senso comum, nas práticas cotidianas e nas atividades rotineiras das pessoas envolvidas na pesquisa.

Esta pesquisa se enquadra na pesquisa etnográfica, uma vez que segundo ANDRÉ (1995), nessa pesquisa os dados são mediados pelo instrumento humano: o pesquisador. Também envolve um trabalho de campo - outra característica relevante na qual a pesquisa se baseia -, além da descrição e da indução do pesquisador e, por último, envolve o estudo de caso.

A metodologia utilizada na presente pesquisa foi a pesquisa-ação, que tem nos seus traços essenciais, a análise, a coleta de dados e a conceituação dos problemas, o planejamento e execução da ação e nova coleta de dados para avaliá-la (LEWIN, 1944 citado por ANDRÉ, 1995).

Conforme afirma COREY (1953), citado por ANDRÉ (1995) a pesquisa-ação caracteriza-se pelo processo de estudar os problemas cientificamente, de modo a orientar, corrigir e avaliar suas ações e decisões.

A nossa pesquisa esteve pautada no estudo da prática escolar cotidiana, que ANDRÉ (1995), enquadra como o contato direto com as pessoas que atuam na instituição de ensino, como os docentes, a coordenação, a direção. Desenvolvemos esse contato por meio de aplicação de questionário e até mesmo através de conversas durante os cursos formais e/ou informais. 
A análise da documentação da instituição de ensino pesquisada - no caso a faculdade SENAC - é uma forte ferramenta da pesquisa, uma vez que ela nos dá a dimensão instrucional ou pedagógica e abrange diretamente as situações de ensino nas quais se dá o encontro professor-aluno-conhecimento.

\subsection{Pesquisa-ação}

A pesquisa-ação permite a interação entre pesquisador e membros das situações investigadas de forma que as pessoas envolvidas busquem a cooperação entre si e a participação conjunta. (GIL, 1987).

Segundo LEWIN (1944) citado por ANDRÉ (1995) a pesquisa-ação é um processo que indica a análise, coleta de dados, planejamento da ação, execução e coleta de dados para avaliá-la.

A pesquisa-ação envolve sempre um plano de ação, plano este que se baseia em objetivos, em um processo de acompanhamento e controle da ação planejada e no relato desse processo. Essa pesquisa é chamada também de intervenção (ANDRÉ, 1995).

Essa metodologia envolve conversas informais, acompanhamento das atividades escolares dentro do foco de pesquisa, que nos permite acompanhar de forma direta o envolvimento do conteúdo - em especial o nosso caso, relacionado ao meio ambiente e o curso de gastronomia - de forma que a pesquisa não fique somente presa à análise de documentos formais (não que esses não sejam importantes, mas certamente a prática cotidiana nos fornece informações de grande valia).

A ação pedagógica abrange diversas situações de ensino entre professor e aluno, uma vez que nessa situação estão envolvidos diversos conteúdos do ensino, diversas atividades pedagógicas, a linguagem e outros meios de comunicação entre o professor e os alunos.

Utilizamos esta metodologia na coleta de dados, visto que reformulamos o plano de ensino de todos os professores, com o objetivo de implantar sistematicamente questões relacionadas ao meio ambiente, à educação ambiental e à formação profissional do cozinheiro, pois esta metodologia nos proporciona o surgimento de pistas que nos conduzem a novas ações, embora ela requeira muita sensibilidade, abertura e flexibilidade para diversas interpretações do objeto pesquisado.

Optamos por esta metodologia também porque na coleta de resultados julgamos interessante a sua categoria, pois nos propicia fazer uma mediação entre a teoria e a 
experiência vivida em campo, dialogar com os referencias de apoio, rever princípios e procedimentos e fazer os ajustes necessários (ANDRÉ, 1995).

Esse tipo de estudo exige do pesquisador um trabalho aberto e flexível, já que existem critérios exatos para o desenvolvimento das tarefas e sensibilidade do pesquisador no que diz respeito ao momento da intervenção, e principalmente na coleta de dados da pesquisa, pois estamos lidando com instituição e no nosso caso especifico mudança de diretoria da faculdade e da coordenação do curso o qual estamos pesquisando.

Essa metodologia de pesquisa foi aplicada durante a nossa intervenção, através do desenvolvimento do curso de formação de professores, objetivando refletir e debater a respeito de temas ambientais, que está no Apêndice $\mathbf{F}$.

\subsection{Análise Documental}

A análise documental é uma técnica extremamente rica, uma vez que demonstra dados qualitativos.

Conforme GIL (1987), o desenvolvimento da pesquisa documental segue os mesmos passos da pesquisa bibliográfica, sendo que esta é impressa e localiza-se em bibliotecas, enquanto naquela, as fontes são muito mais dispersas e diversificadas, pois os documentos nem sempre receberam tratamento analítico e se encontram em órgãos públicos e instituições privadas.

Os documentos analisados comumente são os materiais escritos que possam servir como fonte de informação sobre condutas e procedimentos dos profissionais envolvidos no processo. Estes documentos são, segundo LÜDKE e ANDRÉ (1986): leis, regulamentos, normas, pareceres, cartas, memorandos (na nossa pesquisa encontramos os diários de classe dos professores), arquivos escolares, anotações do processo seletivo e manual escolar do aluno.

A análise documental tem por objetivo buscar informações dos fatos nos documentos a partir de ocorrências ou hipóteses. Os documentos se destacam por nos propiciar uma fonte estável de dados, além de estarem à disposição, no sentido de poderem ser consultados diversas vezes, e também porque poderão servir de base para que outros estudos se tornem relevantes, promovendo estabilidade dos resultados obtidos. 
Os documentos são fontes ricas, já que também podem fornecer evidências que fundamentam as declarações ou afirmações estabelecidas por nós pesquisadores durante o trabalho.

A pesquisa documental nos proporciona uma fonte rica de informações, além de estabilidade de dados. GIL (1987).

Analisamos a inserção do tema ambiental na grade curricular do curso, os planos de ensino das disciplinas que envolvem a grade curricular.

Os documentos analisados incluem questões relevantes e até mesmo nos levam a refletir sobre práticas pedagógicas que ocorrem durante o curso.

A análise qualitativa é um processo criativo que exige grande rigor intelectual e muita dedicação. Tivemos o cuidado de não nos apegarmos somente aos "significados" que as pessoas dão às coisas e sua vida, buscando analisar as informações sem préconceitos ou de forma não equivocada, sob a ótica de valores pessoais, estabelecendo julgamentos ou prioridades de forma individualista.

Tivemos a atenção voltada para o cuidado ao revelar os pontos de vista do participante a partir das suas percepções, respeitando, assim, o entrevistado e também seu ponto de vista. Dessa forma, buscamos durante os nossos encontros, criar meios de checar e discutir com os professores e coordenação, de forma que as informações pudessem ser confirmadas.

Outro aspecto para o qual estivemos atentos foi o da análise dos dados, para que estes não tomassem um rumo inesperado; ou melhor, o da indução, desencadeados por meio de hipóteses, uma vez que a pesquisa envolve dados descritivos do nosso contato direto com a abordagem do professor junto ao aluno, tanto em sala de aula como em atividade prática de laboratório.

Assim, durante as nossas pesquisas, pudemos constatar que a metodologia usada para o desenvolvimento deste trabalho foi favorável, uma vez que curso de cozinheiro do SENAC de Águas de São Pedro trabalha com a educação ambiental como um tema transversal na grade curricular do ensino técnico profissionalizante, mas de maneira informal e desordenada. Portanto, havia a necessidade de um trabalho sistematizado, criterioso e ordenado, para o qual pudemos contribuir.

A partir dessa análise documental e da interação direta, junto aos professores e à coordenação, pudemos propor uma intervenção aos docentes de forma a despertar, sensibilizar e conscientizar sobre a relevância da inserção do tema ambiental como tema 
transversal no currículo, propiciando oportunidades de desenvolver práticas referentes ao tema.

E finalmente buscamos uma forma de intervir junto aos discentes, buscando analisar a efetividade da incorporação da reflexão e das práticas relacionadas ao tema ambiental, no currículo do curso, objetivando uma efetivação da atividade proposta.

Através da análise documental realizada por nós durante a pesquisa, conforme Anexo A, pudemos visualizar amplamente cada informação, incoerências e contradições.

\subsection{Questionário}

O questionário consiste em traduzir os objetivos específicos da pesquisa de forma que possam facilitar a obtenção de informações (GIL, 1987).

Esse interessante instrumento de trabalho foi aplicado tanto no que diz respeito à coordenação, ao corpo docente e mesmo ao corpo discente, uma vez que pretendíamos levantar informações de pessoas de forma padronizada em um determinado espaço de tempo.

Este instrumento foi trabalhado em diversos momentos da nossa pesquisa, enquanto possibilidade de viabilizar o entendimento que os professores tinham a respeito da conexão e inserção do tema ambiental dentro do curso de gastronomia.

Pudemos viabilizar, através desta técnica, a coleta de dados necessária para o desenvolvimento de uma programação que atendesse às necessidades do curso de cozinheiro.

Segundo LÜDKÉ e ANDRÉ (1986), a aplicação de um questionário previamente e cuidadosamente elaborado permite que se tenha um resultado aprofundado de pontos levantados, podendo também ampliar o nível de investigação.

O questionário é uma fonte de excelente informação, uma vez que o entrevistador presente pode esclarecer imediatamente qualquer dúvida, e o "entrevistado" pode prestar eventual esclarecimento.

O questionário pode ser elaborado e estruturado obedecendo padrões, visando à obtenção de resultados também padronizados, permitindo, assim, a comparação imediata. 
Para GIL (1987), as perguntas do questionário devem ser fechadas, mas com ampla possibilidade de respostas, clara, concreta e precisa, levando-se em conta a referência do entrevistado, assim como o seu nível de informação.

Ainda segundo o autor acima, as perguntas devem propiciar uma única interpretação, não deve sugerir respostas, devem referir-se a uma única idéia de cada vez. Além disso, deve haver um número limitado de perguntas.

Através da aplicação dos questionários (Apêndice A, B, C, D, E, H, I), pudemos fazer uma análise concreta do universo de cada participante com o tema proposto na nossa pesquisa.

\subsection{Entrevista Grupal}

A entrevista representa um dos instrumentos básicos para a coleta de dados. Segundo LÜDKE e ANDRÉ (1986), esta técnica de trabalho representa uma das principais, sendo constantemente empregada pelas ciências sociais, uma vez que desempenha um papel importante nas atividades científicas.

Tomamos o cuidado para não nos antecipar e forçar a resposta do entrevistado, através da própria pergunta, conduzindo o informante a responder aquilo que nós gostaríamos de ouvir, ou ainda que pautasse respostas condizentes com o tema explorado por nós enquanto condutores da entrevista.

$\mathrm{Na}$ entrevista a relação que criamos foi de interação, de forma que houvesse uma dinâmica entre quem pergunta e quem responde, em especial nas entrevistas menos estruturadas previamente, nas quais não houve imposições de ordem rígida das perguntas, e que os entrevistados puderam discorrer sobre o tema proposto com base nas informações que detinham.

Com o objetivo de obtermos uma entrevista com sucesso, buscamos nos pautar num clima de estímulo e de aceitação, em que as entrevistas estiveram pautadas na informação de maneira notável e autêntica.

A entrevista, segundo GIL (1987), possibilita flexibilidade, informalidade, devendo ter questões diretas, visando a obtenção de dados com maior profundidade.

Sentimos que a vantagem da entrevista é que ela permite o aprofundamento de diversos pontos levantados e também correções, esclarecimentos e adaptações, tornando eficaz a obtenção de informações. 
A entrevista teve o objetivo de enfocar o tema proposto por nós com a preocupação de não nos distanciarmos do assunto proposto, e visando a obtenção de resultados, de forma flexível e de maneira que pudéssemos estabelecer um diálogo com os entrevistados, fazendo-se os ajustes necessários.

Durante a entrevista nós adequamos o nosso vocabulário ao nível de instrução dos informantes, bem como ao seu universo de valores e preocupações. Com isso, pudemos perceber que houve um clima de estímulo e de aceitação mútua, uma vez que as informações fluiram de maneira notável e autêntica.

Tivemos o cuidado de ouvir atentamente e estimular o fluxo natural de informações, de forma que os entrevistados se sentissem à vontade para se expressar livremente. 


\section{RESULTADOS E DISCUSSÃO}

\subsection{Análise do tema ambiental na grade curricular do curso de cozinheiro}

A grade curricular de um curso propicia a oportunidade de agregar valores de relevância que levam os docentes a formar profissionais com a preocupação global do processo educativo.

O professor do curso de cozinheiro tenta aliar a teoria à prática, buscando ensinar aos alunos técnicas próprias da formação profissional do cozinheiro dentro da área de gastronomia.

Quando o educador busca conciliar a prática aliada à teoria, objetivando uma fusão das duas metodologias de ensino dentro do curso de formação profissional, consolida-se o ato de ensinar e de transmitir.

Nesse contexto, o aluno passa a ser um agente passivo da aprendizagem e o professor um transmissor, não necessariamente presente nas necessidades do aluno.

Segundo AFONSO e ANTUNES (2001), sabe-se que não existe ensino sem que ocorra aprendizagem, que conduz à transformação, pela ação facilitadora do professor, do processo de busca do conhecimento, que deve sempre partir do aluno.

E é nessa corrente construtivista que se apóia a atual reforma do sistema educacional brasileiro, na forma de Lei, conforme vimos anteriormente na LDB e nos Parâmetros Curriculares - PCNs.

Os currículos sempre foram algo estanques e congelados, rígidos e, na maioria das vezes, sem intervenção de temas relevantes à formação futura do indivíduo ou a questões pertinentes ao local, região, ao país e que atingem diretamente cada um de nós seres humanos. As disciplinas que compunham um currículo eram trabalhadas de forma árida, sem conexão com as demais disciplinas e problemas mundiais.

As leis que foram surgindo oportunizaram cada vez mais um trabalho integrado de forma interdisciplinar e transdiciplinar, de maneira que os educadores pretendessem enriquecer os currículos dos cursos, formando pessoas integradas aos problemas 
mundiais de forma a interagir positivamente e conscientemente, formando pessoas críticas e conscientes de seu papel na sociedade.

Os currículos são cada vez mais flexíveis de forma a atender às transformações mundiais e são constantemente adaptados às mudanças necessárias, preocupando-se cada vez mais, além dos conteúdos específicos, com o desenvolvimento de habilidades e de competências de maneira a formar cidadãos com visão holística, crítica e racional.

Os currículos ou grades curriculares ainda são os meios mais eficazes de registrarmos e repassarmos nossas experiências educacionais, mas não devem ser monolíticos, estáticos e impessoais, e sim cada vez mais incorporar as novas necessidades, particularidades de cada grupo e, acima de tudo, estar claros e abertos.

A grade curricular de um curso deve agregar novos paradigmas, trabalhando, assim, a diversidade de valores, levando o indivíduo a pensar em novas atitudes, trabalhando uma mudança de mentalidade, de cultura, de forma integral, buscando-se conexões com os problemas atuais.

No caso específico da grade curricular do curso de cozinheiro (ANEXO A), o professor do curso está preocupado em formar o profissional na sua integridade. Dessa forma, o caráter multifuncional das disciplinas é explorado no todo e aplicado no dia-adia através da atividade prática em que é desenvolvido nos laboratórios o aprendizado de sala-de-aula - embora não esteja presente nos documentos do SENAC, na prática isto já acontece.

A grade curricular do curso contempla disciplinas específicas da formação do futuro profissional de gastronomia, não estando registrado os temas transversais que estão presentes na formação do curso de cozinheiro, mas que segundo a nossa pesquisa estes já ocorrem de maneira informal e desordenada.

Na primeira semana de aula é desenvolvida junto aos alunos a "ambientação do curso", que tem por objetivo colocá-los em sintonia com o universo hoteleiro, especificamente o da gastronomia, de forma que sejam desenvolvidas aulas com temas abrangentes sobre a formação do profissional do curso em questão.

As aulas são teóricas com diversos profissionais de multi-áreas do conhecimento. Dessa forma, o discente tem contato com professores de nutrição - que visam o desenvolvimento de assuntos ligados à higiene e conservação dos alimentos; com psicólogos - que buscam a conscientização da importância do trabalho em equipe na profissão de cozinheiro, uma vez que os setores são interdependentes; com enfermeiros, que conscientizam sobre a importância das precauções e encaminhamentos 
de emergência que necessitam dos primeiros socorros; profissionais do corpo de bombeiro, que atentam para a segurança e a prevenção de acidentes nas áreas dos laboratórios de cozinha; e com os próprios funcionários do hotel-escola, que fazem parte da comissão de cipeiros.

Neste momento de ambientação dos alunos ao curso, são trabalhados junto ao corpo discente temas que explicitam a intenção de incorporar problemas locais, regionais, nacionais ou que atingem a população de ordem global, mas que durante o curso ficam de lado. Assim, o curso ruma para especificidades da atuação do cozinheiro, quando o assunto discutido em sala de aula toma uma dimensão maior, não se restringindo unicamente às técnicas da área de gastronomia ou de hotelaria. A abordagem não é feita de forma ordenada e contínua, e conseqüentemente, não há registros destas (os) informações/conteúdos.

Embora a prática do desenvolvimento do tema "meio ambiente" não esteja presente na grade curricular deste curso, percebemos que há um engajamento voltado para estas questões, ainda que de forma restrita. Entretanto quando em pesquisa direta com os docentes, coordenação e alunos indagamos se há uma intervenção de educação ambiental presente no desenvolvimento pedagógico do curso, os mesmos nos informaram que não há de maneira formal, fazendo-se assim necessário o registro de tais atividades.

O diferencial desse curso é o conjunto de disciplinas práticas que totalizam o grande número de aulas da grade curricular do curso, buscando colocar o aluno/aprendiz em situações reais de trabalho, preparando-o para interagir eficientemente no mercado de trabalho e valorizando as diversas formas de conhecimento, propondo uma intervenção real através da prática e focando a aptidão de cada um para uma sub-área de formação à qual ele demonstre interesse em se aprofundar, propiciando ao professor identificar talentos pessoais dos alunos de forma que os mesmos os desenvolvam, bem como sua especificidade. 


\subsection{Análise do tema ambiental nas práticas pedagógicas do curso de cozinheiro}

A pesquisa da inserção do tema ambiental nas práticas pedagógicas do curso de cozinheiro foi feita por meio da aplicação de questionários tanto à coordenação, quanto aos professores e alunos do curso de gastronomia. Os questionários também tinham como finalidade verificar as concepções dos envolvidos sobre o tema ambiental e servir de subsídio para a elaboração de um curso de formação na área ambiental, voltado aos docentes do referido curso da instituição SENAC Águas de São Pedro.

\subsubsection{Meio Ambiente na cozinha: concepções da coordenação e dos professores da área gastronômica}

Elaboramos um questionário com o objetivo de conhecermos a percepção da coordenação (Apêndice C) e dos professores (Apêndice D), a respeito do meio ambiente e educação ambiental, além de verificarmos se esse tema estava presente nas práticas pedagógicas desses profissionais.

Buscamos através das perguntas direcionadas aos professores e coordenação do curso de cozinheiro identificar a representação social de cada um a respeito da temática ambiental, uma vez que esta, além de ajudar na compreensão de como a pessoa ou o grupo interpreta os fenômenos ambientais, nos dá pistas de como essa temática é tratada no cotidiano dessa pessoa ou grupo. Se esta concepção do meio ambiente é fragmentada, parcial, esta tem a ver com a visão de mundo, com as ideologias, com o senso comum, com as idéias que são vinculadas, com o conhecimento.

A representação social é uma teoria contemporânea que busca compreender como o indivíduo, ou a coletividade, interpreta os fenômenos sociais. É fragmentada, parcial, tem a ver com as visões de mundo, com as ideologias, com o senso comum, com as idéias que são veiculadas, com o conhecimento; assim as representações sociais refletem o contexto sócio-histórico e cultural no qual o sujeito está inserido (REIGOTA, 2001).

Segundo o autor acima, na área de meio ambiente a representação social de indivíduos ou grupos é necessária para se entender como as pessoas pensam e agem no que tange às questões ambientais em sua realidade próxima. 
A lógica utilitarista prevalecente do desenvolvimento econômico e incorpora a incerteza, a desordem e o desequilibro no campo do conhecimento da educação ambiental (TRISTÃO, 2004).

Segundo REIGOTA (2001) as representações sociais circulam, comunicam como determinada temática é vista, e refletem o contexto sócio-histórico e cultural no qual o sujeito está inserido. São passíveis de serem modificadas e de tornarem-se mais elaboradas, mais contextualizadas.

Ainda de acordo com mesmo autor, a identificação da representação social, serve como ponto de partida para a compreensão de como os envolvidos na pesquisa pensam e como situam os problemas ambientais, uma vez que esta "sondagem" possibilita que o sujeito tome consciência de seus pensamentos, de suas idéias, de sua visão, de suas atitudes; ele acomoda os conflitos, encontra uma maneira de tornar familiar aquilo que lhe é desconhecido.

Quando questionados sobre de que forma compreendiam o meio ambiente, várias foram as respostas dadas pelos professores e pela coordenação. Estas foram enquadradas em categorias de acordo com as concepções descritas por REIGOTA (2001): antropocêntrica como a sobrevivência do ser humano, naturalista cuja definição é a natureza tocada e intocada; e por SAUVÉ (2003), que define a natureza como uma forma de apreciar, preservar; o recurso como a administração e o compartilhar; o problema de forma a prevenir, resolver; o sistema como a maneira de compreender para tomar maiores decisões; meio de vida definido como conhecer para desfrutar; território que define o lugar de permanência e identidade; biosfera para o homem viver em longo prazo; e projeto comunitário enquanto compromisso social.

Percebeu-se que as concepções desses profissionais, na maioria das vezes, não se restringem a uma única categoria. Dessa forma, dois professores apresentaram concepções próximas de uma visão naturalista mesclada ao conceito de antropocentrismo. Um professor entende o meio ambiente como uma soma das categorias que definem território e projeto comunitário. Outro profissional, além das duas citadas anteriormente agrega a sua concepção, o conceito de meio de vida. Outro professor possui uma visão próxima à antropocêntrica, aliada ao conceito de território, sendo que a concepção de somente uma pessoa foi enquadrada em apenas uma categoria (biosfera).

Quando analisamos o entendimento pessoal sobre meio ambiente de cada um dos participantes, percebemos uma amplitude de respostas dentro do grupo. Os docentes 
possuem uma ampla representação sobre o assunto meio ambiente, embora tenham concordância plena de que o assunto em questão pode ser considerado não somente como aqueles aspectos ligados à natureza, (ao verde) e sim aspectos relativos à natureza e diretamente presentes dentro da atividade gastronômica.

Sabemos que ainda é muito comum entre os professores a idéia de que meio ambiente é sinônimo de natureza. Como conseqüência pedagógica passam a considerar apenas os espaços naturais como referência para as atividades extra sala de aula (REIGOTA, 2001).

Ao analisarmos a percepção dos professores com relação à questão gastronômica associada ao meio ambiente, percebemos que tais profissionais percebem certa aproximação entre essas duas temáticas. Porém, em alguns momentos, percebe-se um distanciamento dos mesmos com relação ao meio natural, parecendo que o alimento vem "fabricado" de alguma indústria que não proveniente do meio natural. Atribuímos a essa idéia, o fato de que as matérias-primas das preparações são compradas por um setor responsável, não sendo atribuições diretas desses profissionais.

$\mathrm{O}$ fato dos docentes associarem em alguns momentos o antropocentrismo ligado ao meio natural, interpretamos que este se dá pelo fato de atuarem na área de serviços e assim a questão do "ser humano" e das "necessidades" pessoais do "homem" estão em evidência, sobrepondo-se até mesmo à questão natural, sendo que, sem este último não haveria como desempenhar a atividade profissional para atender as pessoas em geral.

Segundo TRISTÃO (2004), é por isso que nenhum avanço se dá em termos de resgatar a interação entre o ser humano e a natureza; se o grande e complexo desafio da educação ambiental não se restabelecer através da integração entre a sociedade e a natureza.

Outra questão presente na percepção de um deles é o projeto comunitário, sendo este item muito presente nas estratégias de atuação do SENAC, uma vez que o mesmo desempenha uma função social, como visto nos capítulos anteriores.

A questão de lugar é expressiva no cotidiano das pessoas que vivem na cidade de Águas de São Pedro, uma vez que o lugar tem um espaço peculiar, de riqueza natural, não somente no que diz respeito à vegetação, mas também à fauna com muitos quatis transitando nas ruas da cidade, variedade de pássaros, dentre outros, tornando o local um território peculiar e de permanência somente das pessoas que se identificam com o lugar. 
Nota-se que a percepção da maioria dos participantes sobre meio ambiente foi que este é sinônimo de natureza. Em conseqüência, passam a considerar apenas os espaços naturais como referenciais.

Com exceção de um professor, que mencionou ter ouvido falar vagamente em educação ambiental, todos os demais e também a coordenação do curso de gastronomia já havia tido contato com tal tema, uma vez que nos últimos anos a atenção voltada para o meio ambiente vem tendo uma maior propagação, através da difusão de idéias, propostas e alternativas de consolidação da qualidade da educação ambiental brasileira.

A mídia é grande responsável pela propagação da idéia de que a questão ambiental é emergente e é uma tarefa de todos, sendo esta uma forma de repensar de maneira eficiente atitudes no sentido de propor transformações, objetivando mudanças que contribuam para a melhoria da qualidade de vida de toda a população.

Segundo LEME (2006) a educação ambiental é um campo em (re)construção. Muitos consensos aparentemente no plano teórico estão longe de muitas práticas, Entretanto, estas vêm produzindo conhecimentos muito promissores.

Assim como as concepções de meio ambiente, as concepções de educação ambiental também puderam ser enquadradas em mais de uma categoria. Dois professores interpretam a educação ambiental como uma forma de gestão do meio ambiente agregado ao conceito de "educação ambiental sobre o meio ambiente", definido por MAYER (1998) como uma transmissão de informações. Do grupo, outras duas pessoas concebem a educação ambiental como uma forma de conservar o meio natural, defendido por SORRENTINO (1998) como educação ambiental conservacionista. Dois outros profissionais entendem a educação ambiental como forma de gestão do meio, sendo que um deles ainda alia essa concepção com a de educação ambiental para o meio ambiente e participação comunitária.

Uma única pessoa define educação ambiental de duas formas, como sendo gestão ambiental e educação para o meio ambiente sendo que a segunda é entendida por MAYER (1998) como atitudes e participação comunitária; uma única pessoa define educação ambiental como uma estratégia de gestão ambiental.

A gestão ambiental, dentre as demais concepções de educação ambiental, é a que aparece com maior relevância. Entendemos que isto se justifica, uma vez que SENAC de Águas de São Pedro forma pessoas na área ambiental através do curso superior de Gestão Ambiental, exercitando atitudes e mudanças de mentalidades e costumes frente 
às questões relacionadas, não somente ao meio natural, mas à atitudes que dizem respeito a inserção social, exercício de cidadania, dentre outras.

A contradição entre o desenvolvimento e qualidade de vida, compatível com nutrição, saúde e bem-estar da população brasileira, está na exclusão social - um dos mais graves problemas da sociedade, pois a cultura do consumo afeta a vida natural e social de todos os cidadãos do planeta (TRISTÃO, 2004).

Percebemos, em conversas informais que tivemos com os professores nos intervalos das reuniões e da aplicação dos questionários, que os hábitos dos professores frente aos alunos aproxima-se de atitudes tradicionais, a fim de transmitir conhecimento, através das condutas e, conseqüentemente, de modelos comportamentais, que na maioria das vezes são trabalhados não somente nas aulas teóricas, mas também nas aulas de laboratório e nas atividades práticas de interação direta do aluno com o hóspede. Assim, cabe aos mestres conduzirem o processo de aprendizagem frente às questões relacionadas a educação ambiental.

Também pesquisamos sobre a ligação da gastronomia ao meio ambiente. Pedimos que os professores comentassem sobre o assunto, a fim de verificarmos a abrangência da questão no que tange a profissão que desempenham e a sua relevância em relação ao meio ambiente. Todos os professores, bem como a coordenação, atribuíram total relevância do tema no que se refere à gastronomia.

Todos os pesquisados entendem que a questão ambiental é de fundamental importância dentro da área gastronômica, uma vez que esta se constitui em uma profissão diretamente relacionada a elementos ambientais. Alguns desses elementos citados pelos profissionais foram: a água, os alimentos, o lixo, a energia e os resíduos. Algumas atitudes pessoais e profissionais com relação aos elementos acima mencionados também foram citadas: o desperdício, as formas de armazenamento de matéria-prima dos alimentos.

A segunda questão presente na pesquisa foi sobre a compreensão sobre educação ambiental, que alguns professores descrevem-na como sendo gestão ambiental.

Para SORRENTINO (1998) significa administrar o espaço e definir o futuro, complementado ainda por educação ambiental sobre o meio ambiente, que segundo MAYER (1998) são atitudes e a participação comunitária. Outros docentes ainda definem a educação ambiental com uma visão que SORRENTINO (1998) diz ser conservacionista que é as ações de conservação. 
Segundo SOUZA SANTOS (1995), a separação entre a teoria e a prática é compreendida dentro do paradigma da ciência moderna, mas que tem uma verdade única, que é o conhecimento científico; assim há um reencontro entre a teoria e prática, criando a teoria e exercendo a prática.

$\mathrm{Na}$ próxima questão indagamos aos professores sobre a relação entre as disciplinas que cada um ministra, com o assunto meio ambiente. Todos responderam que há uma relação direta com o meio natural, e que vêem a relação entre a disciplina e tal temática. Como temas que fazem essa ligação, foram citados: a água, a luz, o lixo orgânico e inorgânico, os resíduos, o desperdício, a conscientização da preservação do meio natural, o uso indiscriminado de produtos químicos relacionados à limpeza e o armazenamento de matéria-prima. Percebe-se nitidamente, pelas respostas do questionário, a importância do tema ser trabalhado em sala de aula. Porém, este não está contemplado nas propostas, embora já ocorra na prática.

Todos os docentes, bem como a coordenação pedagógica, responderam que a relevância da questão ambiental é trabalhada em algumas disciplinas, mas não de forma sistematizada. Então, em algumas turmas de alunos, um determinado professor pode abordar questões relativas ao meio ambiente, e não necessariamente o fazer em outras, devido à várias razões, tais como o fato de estar com o conteúdo atrasado, ou porque o grupo apresentou mais dificuldade de entendimento da aula. Assim, não há uma regularidade da questão ambiental em sala de aula.

O conteúdo ambiental não é desenvolvido continuamente em sala de aula, o que não o torna presente em todas as aulas desenvolvidas durante o curso. Os laboratórios experimentais, bem como os departamentos da cozinha -que são compostos por legumeria, açougue, confeitaria, panificação garde-manger ${ }^{12}$, cozinha quente e cozinha industrial - trabalham de forma isolada as informações, e de acordo com a disposição dos professores; assim, o conteúdo nem sempre está presente nas aulas.

O SENAC de Águas de São Pedro é certificado pela ISO $14.000^{13}$, o que tornou o nosso trabalho de fácil entendimento, embora as reflexões e práticas relativas ao assunto "meio ambiente" e "educação ambiental" são pouco abordadas na rotina de

\footnotetext{
12 "Guarda comida", mas na culinária francesa é uma terminologia que determina o setor que trabalha com preparações frias, então este setor é responsável pela preparação de saladas frias, molhos frios líquidos e emulsionados, montagem e decoração de buffet frio, escultura em legumes, frutas e gelo.

${ }^{13}$ Gestão Ambiental foram inicialmente elaboradas normas visando o "manejo ambiental", que significa "o que a organização faz para minimizar os efeitos nocivos ao ambiente causado pelas suas atividades" (ISO, 2000). Informações disponíveis no site: http://www.cnpma.embrapa.br/projetos/prod_int/iso_14000.html
} 
trabalho, que tem uma atenção voltada para a questão comercial do hotel e não ambiental, o que torna o assunto distante e, na maioria das vezes, superficial nos departamentos da cozinha.

Com o objetivo de ilustrarmos a afirmação anterior, buscamos pesquisar junto aos docentes questões que nos levassem a um entendimento maior sobre algumas atitudes que atendiam inteiramente às premissas de educação ambiental, mas que, não eram exercidas, visando atender questões relacionadas às preocupações voltadas para o meio ambiente ou para a educação ambiental. Por exemplo, o exercício do reaproveitamento de alimentos não visava evitar o desperdício, o desprezo com alimentos que ainda poderiam ser reaproveitados ou mesmo ao bem estar das gerações futuras, mas sim à preocupação econômica, com o objetivo de captar maior lucro para a instituição, dentre outras questões. Assim, questões que inicialmente nos pareciam voltadas para preocupações com o meio ambiente, revelaram-se como sendo "pano de fundo", para questões de ordem econômica ou muitas vezes mercadológica, enquanto propagação da "marca" hoteleira ou educacional no mercado competitivo.

Existem discursos e práticas que buscam a manutenção da sociedade, e aquelas que trabalham para a mudança, sendo a primeira baseada nos indivíduos, e a segunda pressupõe não somente o envolvimento dos indivíduos, mas também dos grupos sociais e das instituições (LEME, 2006).

A próxima questão indagou sobre o plano de ensino da disciplina que o professor leciona, se neste documento está prevista uma abordagem do tema ambiental. Do total de professores, $90 \%$ disseram que sim e os outros $10 \%$ disseram que não está prevista formalmente no plano de ensino, mas que já desenvolvem na prática esporadicamente algo sobre isso, mas que precisariam de maior embasamento para incluir o assunto sistematicamente em sala de aula e nas práticas pedagógicas.

Percebemos durante uma conversa, após a aplicação do questionário, que há algumas atitudes que apontam para a preocupação em relação ao meio ambiente, mas que são práticas impostas pelos gestores aos profissionais que atuam, não somente no departamento de alimentos e bebidas, mas em todos os setores do hotel-escola. Não há, portanto, um entendimento mais aprofundado no que diz respeito à questões do meio ambiente ou da educação ambiental, vinculada a estas atitudes. Por exemplo, existe coleta seletiva do lixo e etiquetagem para o uso dos alimentos com o cuidado de utilizar sempre os do estoque mais velho, mas não há um vínculo do meio ambiente a essa 
prática. Os profissionais praticam esses hábitos sem entender o porquê; simplesmente o executam, alegando serem normas da instituição.

Aqueles que buscam vincular a questão ambiental ao programa do curso não o fazem de forma clara e organizada, uma vez que nunca refletiram sobre as práticas da gastronomia e as práticas pedagógicas com questões relacionadas ao meio ambiente.

Um dos professores sugeriu um estudo junto ao corpo docente dos temas ambientais dentro da culinária, de forma que se trabalhe um programa de desenvolvimento desses profissionais contemplando temas tais como: lixo, reciclagem, higiene, manipulação de alimentos e a importância de estar bem com o meio ambiente para a reprodução satisfatória do trabalho. $\mathrm{O}$ último item sugerido nos remete à reflexão de que há uma sintonia entre a formação profissional na área gastronômica e as questões relacionadas ao meio ambiente. Mas como mencionado anteriormente, o "pano de fundo" da questão não se fundamenta propriamente no tema proposto.

Perguntamos também se há dificuldade de vincular o tema meio ambiente à prática pedagógica desenvolvida nos laboratórios e nas atividades comerciais. Alguns responderam que ela acontece através do tratamento do lixo e do uso adequado nos recursos não renováveis e que há separação e pesagem diária do lixo, visando o não desperdício.

Um dos professores fez uma observação interessante com relação à orientação aos alunos e aos mestres. Afirmou que não basta orientar as pessoas da equipe, mas não se fazer exemplo, pois há muitas vezes exigências, mas não há modelos de atitudes por parte da equipe de trabalho (dos funcionários) e dos professores e chefes. Dessa forma, o aluno não fixa a informação, uma vez que na prática não é reforçada através de atitudes.

Segundo TRISTÃO (2004), a função da escola e do educador é refletir, aprofundar as informações e transformá-las em conhecimento junto ao aluno.

Outros docentes manifestaram a dificuldade de inserir o tema de meio ambiente às aulas de gastronomia, tanto práticas como teóricas, uma vez que o assunto é amplo e complexo.

A seguir questionamos sobre a presença da temática ambiental nas práticas pedagógicas do curso, e constatamos que há, embora não seja registrada nem no diário de aulas e nem nos planos de ensino, mas é desenvolvida de forma desordenada e alienada, sem a preocupação direta com o meio ambiente. 
Por fim pesquisamos sobre como o corpo docente sugere a inserção da temática ambiental ao curso de gastronomia. Para alguns se deve simplesmente oficializar através de apostilas, documentos oficiais (plano de ensino, diário de classe) tudo aquilo que já é realizado na prática; outros acham que ainda carecem de informações e orientações de forma ordenada e profunda, sugerem também treinamento para conhecerem a legislação ambiental; outros, ainda, sugerem reuniões mensais, palestras esclarecedoras, debates e sugestões de implantação do tema dentro da prática profissional dos professores. Uma pessoa menciona estar aberta e disposta a refletir e inserir o tema nas práticas pedagógicas, mas confessa nunca ter pensado muito a respeito dentro da sua atividade profissional.

TABELA 15: Concepção de Meio Ambiente, segundo SAUVÉ (2003) e REIGOTA (2001)

\begin{tabular}{|c|c|c|}
\hline AUTOR & CATEGORIA & DEFINIÇÃO \\
\hline \multirow[t]{10}{*}{ SAUVÉ } & Antropocêntrica & $\begin{array}{l}\text { sobrevivência do ser } \\
\text { humano }\end{array}$ \\
\hline & Problema & prevenir e resolver \\
\hline & Natureza & $\begin{array}{l}\text { forma de apreciar e } \\
\text { preservar }\end{array}$ \\
\hline & Naturalista & natureza tocada e intocada \\
\hline & Recurso & administrar e compartilhar \\
\hline & Sistema & $\begin{array}{l}\text { maneira de compreender } \\
\text { para tomar maiores } \\
\text { decisões }\end{array}$ \\
\hline & Meio de vida & conhecer para desfrutar \\
\hline & Território & $\begin{array}{l}\text { lugar de permanência e } \\
\text { identidade }\end{array}$ \\
\hline & Biosfera & viver a longo prazo \\
\hline & Projeto comunitário & compromisso social \\
\hline \multirow[t]{2}{*}{ REIGOTA } & Antropocêntrica & $\begin{array}{l}\text { sobrevivência do ser } \\
\text { humano }\end{array}$ \\
\hline & Naturalista & natureza tocada e intocada \\
\hline
\end{tabular}


TABELA 16: Concepção de educação ambiental, segundo as categorias definidas por MAYER (1998), SORRENTINO (1998) e REIGOTA(2001):

\begin{tabular}{|l|l|l|}
\hline \multicolumn{1}{|c|}{ AUTOR } & \multicolumn{1}{c|}{ CATEGORIA } & \multicolumn{1}{c|}{ DEFINIÇÃO } \\
\hline \multirow{5}{*}{ MAYER } & $\begin{array}{l}\text { Educação ambiental sobre } \\
\text { o meio ambiente }\end{array}$ & transmissão de informação \\
\cline { 2 - 3 } & $\begin{array}{l}\text { Educação para o meio } \\
\text { ambiente }\end{array}$ & $\begin{array}{l}\text { atitudes e participação } \\
\text { comunitária }\end{array}$ \\
\hline SORRENTINO & $\begin{array}{l}\text { Conservação do meio } \\
\text { natural }\end{array}$ & $\begin{array}{l}\text { educação ambiental } \\
\text { conservacionista }\end{array}$ \\
\cline { 2 - 3 } & Gestão ambiental & $\begin{array}{l}\text { administar o espaço e } \\
\text { definir o futuro }\end{array}$ \\
\cline { 2 - 3 } & Economia ecológica & $\begin{array}{l}\text { ecodesenvolvimento, } \\
\text { desevolvimento sustentável } \\
\text { e sociedades sustentáveis }=\end{array}$ \\
\hline \multirow{2}{*}{ REIGOTA } & Conservacionista & ato de conservar \\
\cline { 2 - 3 } & Natureza & apreciar e preservar \\
\cline { 2 - 3 } & Recurso & administrar e compartilhar \\
\hline
\end{tabular}

TABELA 17: Concepção de Meio Ambiente da coordenação e dos professores do curso de Gastronomia, segundo as categorias definidas por SAUVÉ (2003) e REIGOTA (2001):

\begin{tabular}{|l|l|c|}
\hline \multicolumn{1}{|c|}{ PERGUNTA } & \multicolumn{1}{|c|}{ CATEGORIA } & PORCENTAGEM \\
\hline \multirow{3}{*}{$\begin{array}{l}\text { O que você entende } \\
\text { por meio ambiente } ?\end{array}$} & Naturalista + antropocêntrica & $25 \%$ \\
\cline { 2 - 3 } & Território + projeto comunitário & $17 \%$ \\
\cline { 2 - 3 } & $\begin{array}{l}\text { Território + projeto comunitário + meio } \\
\text { de vida }\end{array}$ & $17 \%$ \\
\cline { 2 - 3 } & Antropocêntrica + território & $33 \%$ \\
\cline { 2 - 3 } & Biosfera & $8 \%$ \\
\hline
\end{tabular}


TABELA 18:Concepção de educação ambiental da coordenação e dos professores do curso de Gastronomia, segundo as categorias definidas por SAUVÉ (2003) e REIGOTA (2001):

\begin{tabular}{|l|l|c|}
\hline \multicolumn{1}{|c|}{ PERGUNTA } & \multicolumn{1}{|c|}{ CATEGORIA } & PORCENTAGEM \\
\hline $\begin{array}{l}\text { O que você entende por } \\
\text { educação ambiental } ?\end{array}$ & $\begin{array}{l}\text { Gestão do meio ambiente + educação } \\
\text { ambiental sobre o meio ambiente }\end{array}$ & $33 \%$ \\
\cline { 2 - 3 } & Conservação do meio natural & $17 \%$ \\
\cline { 2 - 3 } & Gestão do meio ambiente & $8 \%$ \\
\cline { 2 - 3 } & $\begin{array}{l}\text { Gestão do meio ambiente + educação } \\
\text { ambiental para o meio ambiente }+ \\
\text { participação comunitária }\end{array}$ & $8 \%$ \\
\cline { 2 - 3 } & $\begin{array}{l}\text { Gestão do meio ambiente + educação } \\
\text { ambiental para o meio ambiente }\end{array}$ & $17 \%$ \\
\cline { 2 - 3 } & Estratégia de gestão ambiental & $17 \%$ \\
\hline
\end{tabular}

8.2.2 Concepções dos alunos sobre a inserção do tema ambiental na área gastronômica

Elaboramos um questionário, com o objetivo conhecer a percepção dos alunos (Apêndice E), a respeito do assunto Meio Ambiente e Educação Ambiental e também de verificar se o tema ambiental estava presente nas práticas pedagógicas do curso em questão.

Quando questionados sobre de que forma compreendiam o meio ambiente, várias foram as respostas dadas pelos alunos. Estas foram enquadradas em categorias de acordo com as concepções descritas por SAUVÉ (2003): antropocêntrica como a sobrevivência do ser humano; problema de forma a prevenir, resolver; recurso enquanto forma de administrar e compartilhar; meio de vida, com finalidade de conhecer para desfrutar; ou sistema, no sentido de compreender para tomar maiores decisões. Alguns mesclam a concepção agregando mais de uma definição, como a naturalista, cuja definição é a natureza tocada e intocada. Outras concepções observadas incluem as definições de educação ambiental dadas por REIGOTA (2001), que define a natureza como uma forma de apreciar, preservar; o recurso como a administração e o compartilhar. Para um dos alunos, este é definido como uma ação antropocêntrica aliada ao problema. Por fim, alguns alunos agregam três (03) atributos, tais como: recurso, problema e o antropocentrismo.

A segunda questão presente na pesquisa foi a respeito da compreensão sobre educação ambiental, que se enquadra para alguns alunos com uma única definição; 
enquanto para outros a educação ambiental tem uma ou mais definições. Dessa forma, para alguns é vista como naturalista e educação ambiental sobre o meio ambiente, outros enquadram-na como gestão ambiental e conservacionista. Uma única pessoa a definiu como naturalista, associada à gestão ambiental. Outro a definiu como conservacionista e naturalista; e um aluno a definiu exclusivamente como conservacionista.

Alguns se satisfazem exclusivamente com uma única definição, enquanto outros atribuem até três definições à educação ambiental: gestão ambiental, associada à economia ecológica - que segundo SORRENTINO (1998) significa ecodesenvolvimento, desenvolvimento sustentável e sociedades sustentáveis, agregando ainda a informação de conservacionista que a própria palavra nos indica ao ato de conservar.

Outro aluno define como economia ecológica, agregando ainda educação para o meio ambiente; para outro a educação ambiental esta associada à gestão do meio ambiente e a educação sobre o meio ambiente; enquanto outro aluno entende a educação ambiental somente como naturalista; e por fim um único também atribui três definições à educação ambiental, como sendo a naturalista, a gestão ambiental e a educação ambiental sobre o meio ambiente.

A interpretação dos alunos pesquisados, pouco está atrelada ao universo gastronômico, uma vez que esses alunos estavam iniciando o seu curso, e há uma clara evidência de que a informação que eles trazem sobre o meio ambiente esta ligada às informações da mídia.

$\mathrm{Na}$ terceira questão, perguntamos sobre a ligação da gastronomia ao meio ambiente e pedimos que comentassem sobre o assunto, a fim de verificarmos a abrangência da questão no que tange à profissão que desempenham e a sua relevância com relação ao meio ambiente. Todos os alunos atribuíram total relevância à ligação gastronomia/meio ambiente.

Os comentários sobre a ligação gastronomia/meio ambiente foram relacionadas à matéria-prima, água, alimento, madeira, contaminação, lixo, resíduos, saúde, desperdício, armazenamento, pessoas, habitat e higiene.

A quarta questão abordada foi em relação às disciplinas que compõem o curso de cozinheiro: se há dentro da grade curricular alguma que, em especial, trabalha a questão ambiental em sala de aula ou em laboratório (onde se desenvolvem as aulas experimentais) e quais as questões relevantes abordadas pelos professores. 
A maioria dos alunos respondeu que a relevância da questão ambiental é comentada em algumas disciplinas, mas não de forma sistematizada. O que vê é que em algumas turmas um determinado professor aborda questões relativas ao meio ambiente, mas o mesmo não acontece necessariamente em outras turmas, ou porque naquele dia a matéria está atrasada ou porque o grupo apresentou maior dificuldade de entendimento da aula; ou seja, não há uma regularidade da questão em sala de aula.

Segundo FREITAS (2003), na área de humanas, os espaços de reflexão e participação democrática estão mais presentes em relação às demais áreas.

$\mathrm{O}$ fato de o assunto ambiental não se fazer presente sistematicamente em sala de aula, se dá principalmente por três fatores: o primeiro é a falta de informação ou informação superficial sobre o assunto; o segundo é a falta de organização das informações ambientais ao conteúdo de aula; e a terceira se dá pelo fato desse tema transversal não estar presente em plano de ensino de forma alinhavada, sedimentando a sua importância.

Esse fato se justifica segundo a interpretação de alguns autores com relação à compreensão da interdisciplinaridade dentro do plano de trabalho ${ }^{14}$ do professor, uma vez que o processo de integração e interação entre as disciplinas se dá como um estágio mais avançado a ser alcançado, se configurando como a transdisciplinaridade (JAPIASSÚ, 1976).

Já FAZENDA (1994), considera a transdisciplinaridade e a interdisciplinaridade como uma idealização utópica, uma vez que não faz distinção entre os dois temas.

Para MORIN (2000) a interdisciplinaridade controla as disciplinas de forma que cada uma demarca seu território; enquanto a transdisciplinaridade está mais próxima de transcorrer os conceitos através das diversas disciplinas que compõe um programa de curso; assim, seria necessário o diálogo entre elas.

As questões mais comumente citadas pelos alunos que estão presentes em sala de aula são temas como o desperdício, aproveitamento de matéria-prima, higienização, separação de resíduos, etiquetagem, manipulação, aparência, organização e contaminação.

$\mathrm{Na}$ fala dos alunos durante a pesquisa e depois da entrega dos questionários, pudemos perceber que questões de grande relevância presentes em sala de aula, tais

\footnotetext{
${ }^{14}$ Preferimos denominar plano de trabalho com o entendimento de que é executado pelo professor, uma vez o plano de ensino, muitas vezes pode constar no papel, mas não necessariamente ser executado na prática em sala de aula.
} 
como a contenção de despesas (no que diz respeito à desperdício e a apresentação dos pratos), foram abordadas tanto pelos alunos, como pelos professores. Mas essa abordagem não diz respeito ao meio ambiente, e sim às questões comerciais, pois se pauta na venda de alimentos (no caso específico do Hotel Escola SENAC, para uma clientela classe $\mathrm{A}^{15}$ ).

Percebemos que as questões acima mencionadas pelos alunos não têm somente um sentido comercial e financeiro. Existe a preocupação ambiental, mas esta não é prioritária, e nem sempre é lembrada pelos alunos. Já as abordagens comercial e financeira estão sempre presentes nas preocupações dos professores.

$\mathrm{Na}$ próxima questão solicitamos sugestões para a incorporação do tema ambiental ao curso de formação profissional em gastronomia.

Uma das sugestões foi a inserção de um documentário sobre as secas no país, sobre a fome, as doenças que a população contrai com a falta de saneamento básico; as dificuldades encontradas nas favelas; as causas do desmatamento, da poluição do ar; e o uso indiscriminado de água. Outra sugestão foi a apresentação de palestras específicas de cada profissional da área de acordo com o setor de prática da cozinha.

Outro aluno fez uma sugestão interessante quando mencionou ser inviável trabalhar o tema ambiental na teoria se este não for reforçado nas atividades práticas. Assim, o explicitado em sala de aula deve ser praticado nos laboratórios no dia-a-dia, tanto pelos alunos como pelos profissionais e pelos mestres e chefes.

Para outros não há o que acrescentar; eles somente reforçam que o SENAC de Águas de São Pedro já pratica e bem a preocupação frente ao meio ambiente.

Embora alguns entendam que o meio ambiente é um assunto pouco comentado no curso técnico - especificamente no curso de gastronomia - não fizeram nenhuma sugestão, desconhecem o tema ou ouviram falar superficialmente.

De acordo com os alunos, as disciplinas, de forma geral, precisam abordar mais o tema em questão, ou agregar pesquisas sobre o meio ambiente, vinculado ao assunto diário de sala de aula.

Alguns alunos sugeriram incorporar a questão ambiental através de cartazes, painéis instrutivos, de forma que atinjam todos os níveis hierárquicos do hotel-escola. Assim, poderá envolver alunos, funcionários de diversos setores, a sua estrutura hierárquica e estagiários, não somente de outras unidades do SENAC do Estado de São

\footnotetext{
${ }^{15}$ Pessoas de poder aquisitivo alto e com nível de exigência elevado no que diz respeito aos serviços prestados na área de hospitalidade.
} 
Paulo e unidade local, mas também de outras empresas que por ali passam de dentro e de fora do país.

Para outros, a profissão de cozinheiro tem íntima relação com o meio ambiente, embora pouco trabalhado teoricamente dentro do curso, carecendo um departamento que abordasse essas questões juntamente com os professores.

A informação transmitida diariamente não é executada de forma eficaz, não havendo reforço prático da mesma.. Nota-se que os alimentos poderiam ser melhores aproveitados de forma geral.

Alguns alunos percebem que há um trabalho intenso de separação de lixo por parte dos instrutores, chefes, alunos e ajudantes de cozinha, mas quando os faxineiros passam nos setores recolhendo o lixo, eles o depositam em um único recipiente, mesmo que os resíduos ou lixo já tenham sido separados. Dessa forma, nos parece que a conscientização quanto a ISO 14000 ocorreu somente com algumas camadas dos funcionários do hotel-escola.

Os professores debateram sobre os resultados apresentados, tanto na tabulação dos resultados da investigação com os professores e coordenação, como em relação aos resultados das questões apresentadas aos alunos, e mencionaram que fica perceptível o quanto o grupo deixa de registrar de maneira formal questões que são abordadas e trabalhadas em aula junto aos alunos. Assim, existem muitas ações, mas que não são evidenciadas através de registros formais, o que pode resultar em um descompromisso por parte dos docentes, cujas ações podem ocorrer com determinados grupos e não com outros. Além disso, o curso apresenta um maior compromisso do que realmente está registrado, pois na prática acontecem mais abordagens do que os registros acadêmicos formais evidenciam. Ou seja, uma supervisão da diretoria de ensino que não tivesse a preocupação e/ou tempo hábil para um acompanhamento prático não tomaria conhecimento de que certas abordagens são mencionadas durante o curso. Sendo assim, o SENAC não registra tais atividades com os temas transversais, não somente no que tange o meio ambiente, mas questões relativas à religião e crenças que são muito trabalhadas no universo gastronômico em nível nacional e internacional, dentre outras questões.

Outro fator mencionado durante este encontro evidencia a não eficácia de ação por parte dos professores em aulas ou mesmo em atividades de laboratório. Ou seja, algumas questões relativas à higiene, separação de lixo, armazenamento e conservação de alimentos são abordadas em sala de aula, mas não são executadas na prática. Ainda 
assim, são cobradas em atividades práticas, o que contribui para a ineficácia e não efetividade, tanto de ações como de conteúdo curricular.

A busca da conscientização do papel do professor como modelo de formação profissional no papel que desempenham dentro do hotel-escola é um compromisso latente no grupo, para o qual todos estão dispostos a contribuir e a cumprir o seu papel no exercício de educador. Assim, há uma pré-disposição em formar profissionais que tenham o compromisso com a excelência na área de serviços.

Durante o debate um dos professores que já tem uma vivência particular no campo político dentro do município, e que tem especial espírito de liderança, mostrando-se reflexivo e crítico, sugeriu a possibilidade de ser fundada uma cooperativa que ficasse responsável pelo lixo e que fosse composta por funcionários, com o objetivo de separar, estocar e vender os resíduos recicláveis, resultando em fundos que revertessem em beneficio deles próprios (funcionários), uma vez que atualmente o lixo é totalmente doado para uma empresa na cidade vizinha de São Pedro, o que não favorece um estímulo aos profissionais das diversas áreas do hotel-escola a separarem o lixo com eficiência.

Os alunos chegaram a comentar que a empresa responsável pela coleta do lixo do hotel-escola comercializa o lixo arrecadado. A impressão que temos nesta atitude e na fala dos professores é de que o SENAC tem um grande compromisso financeiro com o lixo, deixando de lado questões voltadas para o meio ambiente. Isso nos leva a refletir sobre a verdadeira função do SENAC, enquanto formador de futuros profissionais no mercado de trabalho.

TABELA 19: Concepção de Meio Ambiente dos alunos do curso de Gastronomia, segundo as categorias definidas por SAUVÉ (2003) e REIGOTA (2001):

\begin{tabular}{|l|l|c|}
\hline \multicolumn{1}{|c|}{ PERGUNTA } & \multicolumn{1}{|c|}{ CATEGORIA } & PORCENTAGEM \\
\hline \multirow{2}{*}{$\begin{array}{l}\text { O que você entende por } \\
\text { Meio Ambiente? }\end{array}$} & Naturalista & $22 \%$ \\
\cline { 2 - 3 } & Antropocêntrica + problema & $65 \%$ \\
\cline { 2 - 3 } & $\begin{array}{l}\text { Recurso + problema }+ \\
\text { antropocêntrica }\end{array}$ & $13 \%$ \\
\hline
\end{tabular}


TABELA 20: Concepção de educação ambiental dos alunos do curso de Gastronomia, segundo as categorias definidas por SAUVÉ (2003) e REIGOTA (2001):

\begin{tabular}{|l|l|c|}
\hline \multicolumn{1}{|c|}{ PERGUNTA } & \multicolumn{1}{|c|}{ CATEGORIA } & PORCENTAGEM \\
\hline $\begin{array}{l}\text { O que você entende por } \\
\text { Educação Ambiental? }\end{array}$ & $\begin{array}{l}\text { Naturalista + educação ambiental } \\
\text { sobre o meio ambiente }\end{array}$ & $8 \%$ \\
\cline { 2 - 3 } & Gestão ambiental + conservacionista & $17 \%$ \\
\cline { 2 - 3 } & $\begin{array}{l}\text { Naturalista associado a gestão } \\
\text { ambiental }\end{array}$ & $8 \%$ \\
\cline { 2 - 3 } & Conservacionista + naturalista & $8 \%$ \\
\hline & Conservacionista & $17 \%$ \\
\cline { 2 - 3 } & $\begin{array}{l}\text { Gestão ambiental + economia } \\
\text { ecológica }\end{array}$ & $8 \%$ \\
\cline { 2 - 3 } & $\begin{array}{l}\text { Economia ecológica + educação para } \\
\text { meio ambiente }\end{array}$ & $8 \%$ \\
\cline { 2 - 3 } & $\begin{array}{l}\text { Gestão ambiental + educação sobre o } \\
\text { meio ambiente }\end{array}$ \\
\cline { 2 - 3 } & naturalista & $8 \%$ \\
\cline { 2 - 3 } & $\begin{array}{l}\text { Gestão ambiental + educação sobre o } \\
\text { meio ambiente }\end{array}$ & $8 \%$ \\
\hline
\end{tabular}

\subsection{Intervenção: a formação ambiental dos docentes dentro do universo gastronômico}

Baseado nos resultados obtidos com os questionários, nos quais todos os participantes (coordenação, professores e alunos) afirmaram a relevância e a urgência de se abordar o tema ambiental nas práticas do curso, propusemos uma intervenção com os docentes a fim de debatermos de que maneira que este tema poderia ser inserido na área gastronômica. Pretendemos que essa inserção resulte em uma continuidade e efetividade do tratamento do tema ambiental em todas as turmas formadas pela instituição.

Agendamos com os professores e com a coordenação uma primeira reunião, que tinha por objetivo discutir temas como: a conceituação de meio ambiente e de educação ambiental para o grupo de professores, a relevância de tal temática dentro da cozinha e da gastronomia, a inserção do tema em questão na prática pedagógica do professor (tanto em sala de aula como nas aulas de laboratório) e o compromisso de disseminar conhecimentos relevantes ao tema em questão.

A programação de tal curso encontra-se detalhada no Apêndice $\mathbf{F}$.

O conhecimento, assim como a informação, não tem o mesmo teor, uma vez que a informação possibilita o acesso e é indiferente ao significado; e o conhecimento 
estabelece significado, sendo que este último é vivenciado mais intensamente (BRUNER, 1997).

Durante as diversas reuniões percebemos uma motivação por parte dos professores em falar sobre o assunto, mas a questão ambiental era considerada um tema de grande relevância, apesar de pouco abordada; primeiramente porque o que esses profissionais sabem a respeito do assunto é superficial e restrito; segundo porque, com a implantação da ISO 14000 dentro do hotel-escola SENAC, os professores têm uma ótica voltada para os temas mercadológicos e financeiros, e não um comprometimento de respeito ao meio ambiente e de relevância futura.

A preocupação a que nos referimos acima não se restringe somente aos professores, mas aos funcionários do hotel-escola, de forma que estes possuem um cuidado grande com a questão do desperdício, visando à contenção de despesas e não à conservação do meio ambiente. Não havia preocupação em abordar temas como o consumismo, preocupação com gerações futuras.

Outra questão presente foi à preocupação com a higiene, sempre focada na problemática do hotel-escola caso houvesse um caso de contaminação - preocupação esta vinculada ao nome comercial do hotel, e não necessariamente ao bem-estar dos funcionários, alunos e hóspedes, que fazem a sua alimentação dentro dos restaurantes do hotel-escola.

Isso não significa que não haja um compromisso com o bem-estar do $\operatorname{comensal}^{16}$, mas em primeira instância está a preocupação com a apresentação dos alimentos, com a variedade, com o sabor, com a abundância; uma vez que o hotelescola tem um dos seus glamours pautado de que o Grande Hotel é um centro de desenvolvimento gastronômico, não somente por seus cursos reconhecidos nacional e internacionalmente, mas principalmente por desenvolver experimentos e preparos inéditos, e em conseqüência destes quesitos, a qualidade está presente.

Quando esporadicamente mencionados, esses tópicos (meio ambiente e educação ambiental) não estão previstos no planejamento curricular e nem são trabalhados de forma organizada e engajada ao conteúdo curricular, o que não assegura sua inserção efetiva no currículo do curso. A preocupação com tais questões fica, então, exclusivamente a cargo do professor.

\footnotetext{
${ }^{16}$ Cliente ou hóspede que sente à mesa para desfrutar tranqüilamente da refeição sem presa ou tempo para terminá-la.
} 
O saber ambiental deveria estar inserido em situações de trabalho em que os professores pudessem adaptar seus conhecimentos, aprimorando-os de forma que consigam contextualizá-los com sua experiência profissional e com a situação específica para cada grupo de alunos, em função de uma dada situação.

Os professores que buscavam a abordagem ambiental associada ao conteúdo curricular trabalhavam apenas como transmissores de informações; quando na verdade o próprio grupo de professores mencionou durante a reunião, a necessidade de se explorar mais os alunos nas questões que tangem pesquisa prática e teórica, envolvendo a realidade culinária dos laboratórios e da comunidade local, buscando novos canais dentro do hotel-escola que resultem em inserção social, disseminação da questão ambiental e troca de experiências locais.

A partir destas questões abordadas e discutidas em diversos momentos com os professores e coordenação, pudemos elaborar um programa de desenvolvimento de vários encontros que resultaram em um curso de formação ambiental para os docentes.

Segundo TRISTÃO (2004), a necessidade de uma crescente internalização da questão ambiental, um saber ainda em construção, demanda um esforço em fortalecer visões integradoras que, centradas no desenvolvimento, estimulem uma reflexão sobre a diversidade e a construção de sentidos em torno das relações sociais, sobre os riscos ambientais, globais e locais, sobre a relação ambiente e desenvolvimento.

O interesse em desenvolver um curso pautado no tema ambiental se deu devido à necessidade de sensibilizar os profissionais de gastronomia e, em especial, os professores, que em sua prática docente são profissionais formadores de opinião, que interagem diretamente com os recursos naturais dentro da culinária. Os alunos formados pelos profissionais em questão atuarão em todo o Brasil, agindo, deste modo, em esfera nacional e internacional.

Assim, esta pesquisa visa situar práticas frente ao tema em questão, visto que a atuação profissional é desenvolvida de forma operacional, lidando imediatamente com as atividades que interferem diretamente no meio ambiente. Então, julgamos ser fundamental que esses aprendizes e futuros profissionais tenham uma compreensão de temas relativos ao meio ambiente.

O levantamento de informações feito através dos questionários nos serviu como subsídio para uma intervenção através do desenvolvimento de um programa de formação sobre meio ambiente e a sua correlação com a área gastronômica que tinha o foco voltado para a inserção do tema ambiental, dentro da grade curricular do curso. 
A referida intervenção se deu com a realização de um workshop, cujo programa foi definido após várias reuniões efetuadas junto à coordenação do curso e à direção da faculdade.

Este encontro somente aconteceu depois da pesquisa efetuada junto aos professores, alunos e coordenação sobre o entendimento de cada um com relação à definição de meio ambiente e educação ambiental, e das práticas pedagógicas relacionadas ao tema ambiental desenvolvidas no curso.

A seguir relataremos a experiência e o programa desenvolvido durante os encontros com os professores.

\subsubsection{Reflexão e construção da compreensão de meio ambiente pelos professores de gastronomia}

No primeiro encontro, os participantes tiveram a oportunidade de refletir sobre o conceito de meio ambiente. Para isso, utilizamos uma atividade de recorte de figuras e colagem com o propósito de executarmos um painel que evidenciasse individualmente a representação de meio ambiente para cada participante. Na Figura 1, elegemos dois painéis que julgamos explicitar claramente a concepção do grupo durante o debate e a formulação da concepção de meio ambiente.

Trabalhamos a concepção de meio ambiente através de uma oficina em que os professores construíram individualmente o seu conceito. Posteriormente cada participante expôs a sua concepção de meio ambiente; fizemos uma discussão grupal na busca de um único conceito, como fruto dos participantes. Sentimos o grupo perdido quando no que se referia à construção desse conceito, sem ajuda do instrutor e de forma individualizada, gerando um desconforto pela responsabilidade individual atribuída a cada um deles.

Segundo FREITAS (2003), as novas possibilidades de ensino-aprendizagem, a possibilidade de trabalho conjunto e efetivo entre pessoas diferentes, representam o exercício da troca, do confronto entre idéias e visões de mundo, permitindo aprofundar o entendimento das diferenças e das divergências, o que implica em novas relações de alteridade, frente à necessidade de "ouvir" o outro.

Antes da apresentação buscamos conversar sobre o tema, refletindo na pesquisa que fizemos em grupo, na procura de definições de vários autores através de uma busca minuciosa. 
Percebemos que os elementos presentes na investigação de um conceito de meio ambiente dentro do curso de gastronomia são o verde, a natureza e água.

A definição elaborada sobre meio ambiente pelo grupo ficou dividida em duas categorias. O primeiro grupo de professores definiu o meio ambiente como sendo o "conjunto de recursos naturais indispensáveis para todos os seres" e o outro grupo definiu como sendo "um conjunto de prevenção e preservação para o bem estar do ser humano e do ambiente".

Assim, sugerimos que as pessoas debatessem e buscassem um senso comum com o objetivo de refletir melhor sobre o conceito de meio ambiente, visto que os participantes não tinham um conceito próprio elaborado a respeito do assunto.

Durante o planejamento pensamos em trabalhar tanto o conceito de meio ambiente como o de educação ambiental, através de leituras de textos que pudessem nortear o nosso encontro com os docentes, mas fomos alertados pela coordenação que o grupo de professores não tem o hábito da leitura e nem tampouco facilidade com a mesma, uma vez que o nível de escolaridade do grupo é muito diverso. Alguns professores possuem apenas o ensino fundamental ou médio completo e outros estão cursando ou já terminaram o ensino superior.

Para finalizar este encontro demonstramos algumas definições de alguns autores, sobre as quais eles refletiram, elegendo aquela com que mais se identificaram. Deixamos a apresentação das definições dos autores para o final do encontro, afim de não influenciar a elaboração da definição do grupo.

Os autores citados e as definições de meio ambiente que apresentamos para o grupo foram seguintes:

Meio ambiente é "um lugar determinado elou percebido onde estão em relações dinâmicas e em constante interação os aspectos naturais e sociais. Essas relações acarretam processos de criação cultural e tecnológica e processos históricos e políticos de transformação da natureza da sociedade".

Marcos Reigota (1994)

Meio ambiente é "o conjunto de condições, leis, influências e interações de ordem física, química e biológica, que permite, abriga e rege a vida em todas as suas formas".

Política Nacional de Meio Ambiente (1981) 
"Natureza ou meio ambiente é um conjunto de elementos vivos e não vivos que consistem o planeta Terra. Todos esses elementos relacionam-se, influenciando e sofrendo influência entre si, em um equilíbrio dinâmico".

Mauro Guimarães (1995)

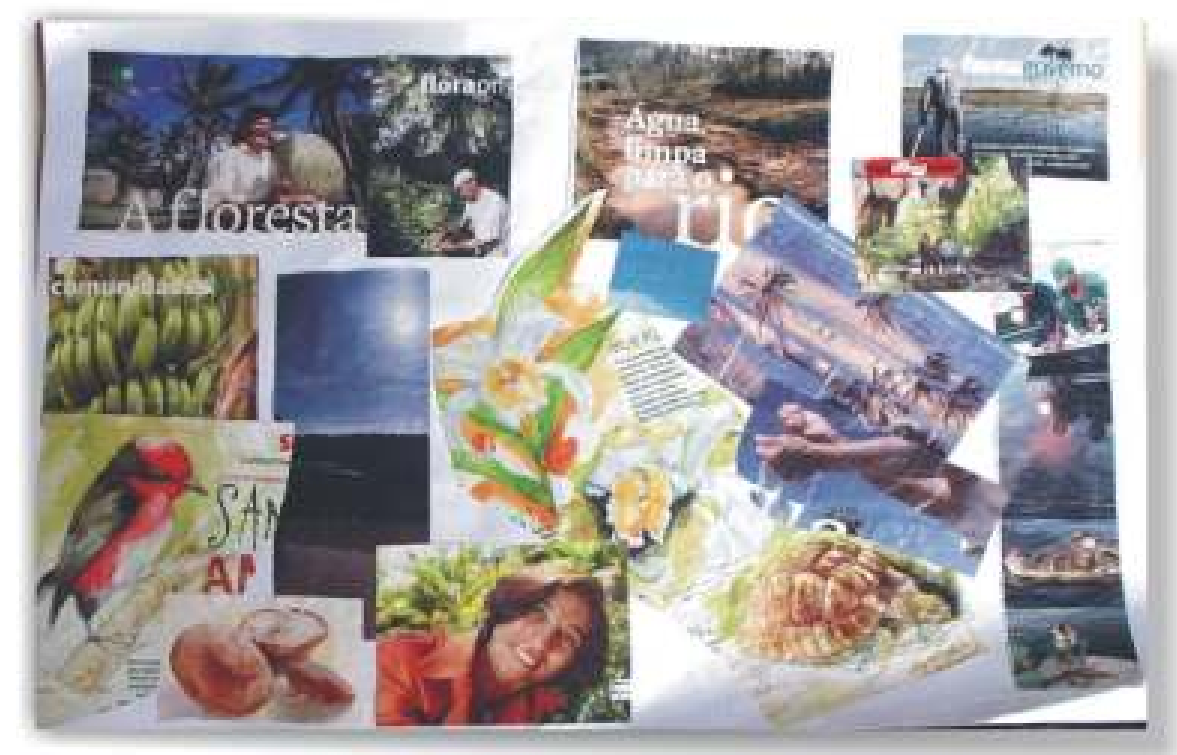

Figura 1 - Painel elaborado pelos professores sobre a representação de meio ambiente (painel 1)

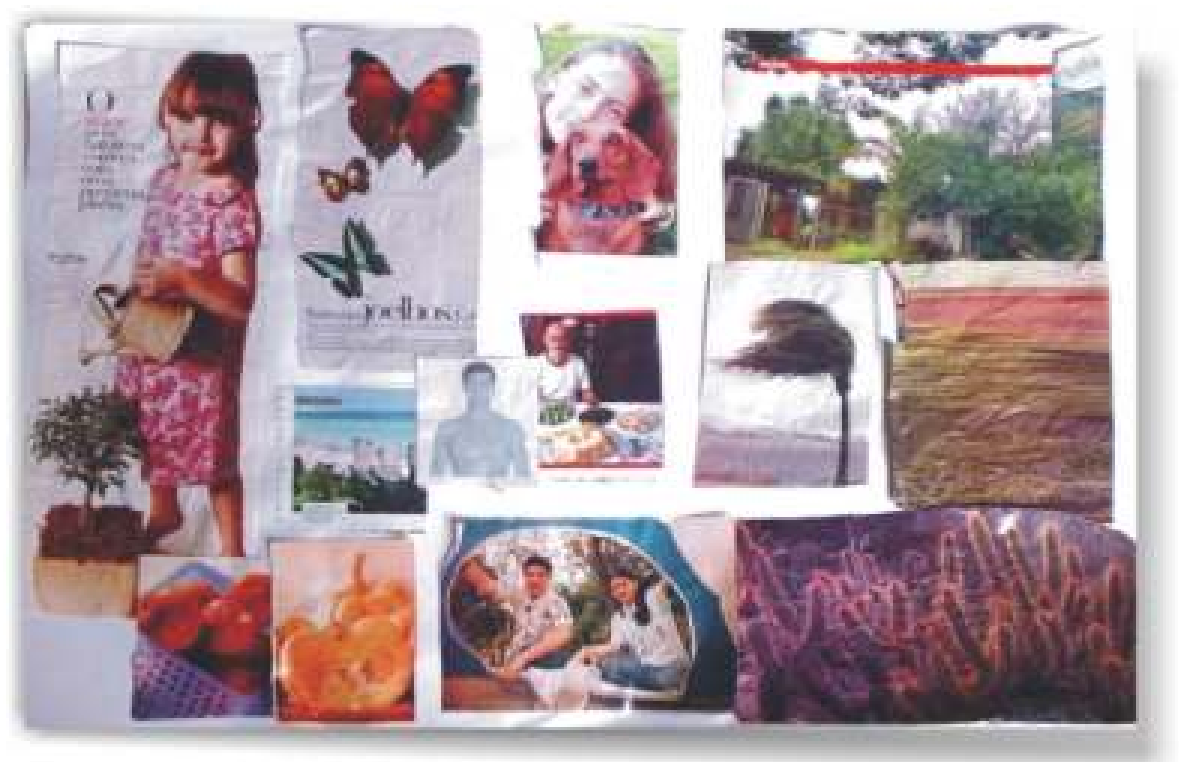

Figura 2 - Painel elaborado pelos professores sobre a representação de meio ambiente (painel 2) 
Assim, durante a discussão pedimos às pessoas que definissem com palavraschave o conceito de meio ambiente, objetivando facilitar o exercício. Foram citadas as palavras: plantas, animais, humanos, seres vivos, bem-estar e harmonia.

$\mathrm{Na}$ busca de um consenso solicitamos ao grupo do curso de Gastronomia que estabelecesse uma definição única para o conceito de meio ambiente, mas o que não estava de acordo para um dos grupos era a palavra "preservação" ao conceito "medidas, ações, cuidado, manutenção".

Após muita conversa, reflexão e argumentação a respeito do assunto, os professores entraram num acordo e estabeleceram uma definição de meio ambiente para o curso de gastronomia:

"Um conjunto de recursos naturais indispensáveis para a harmonia de todos os seres vivos".

Nesta definição percebemos o quanto o grupo de professores lida com a questão ambiental de forma superficial e limitada. Percebemos que eles não têm "intimidade com o tema" e nem tampouco muita leitura a respeito do assunto. $\mathrm{O}$ assunto é tratado em sala de aula, baseado em informações gerais, muitas vezes - como sabemos manipuladas pela mídia.

Também pudemos perceber que eles têm consciência disso e que buscam, aparentemente nesse momento, mais informações, pois as reuniões, as conversas a respeito do assunto, a aplicação do questionário, gerou um desconforto e demonstrou a forma limitada com que eles trabalhavam o assunto em questão.

A impressão que tivemos com a definição do grupo sobre o tema é de que a natureza está ainda à serviço do ser humano. Com isso, teremos que tomar o máximo de cuidado para despertarmos outra visão com relação ao meio ambiente, porque pudemos constatar que a maioria das pessoas do grupo não admitiu que são antropocêntricos, mas a própria definição nos demonstra isso.

Outra questão que percebemos é que os recursos (matéria-prima), segundo a definição dos professores, são indispensáveis, uma vez que a culinária depende diretamente desses recursos. Nos deu a impressão de que durante o debate, eles se conscientizaram de que é uma questão de sobrevivência profissional e pessoal dos mesmos. 
O grupo estabeleceu que esta definição deverá estar presente nas salas de aula e nos planos de ensino de todos os professores da gastronomia, mesmo para aqueles que não estavam presentes neste dia, de tal forma que os alunos sejam sensibilizados a respeito do assunto.

O objetivo é permitir aos alunos que adquiram um conjunto de saberes específicos, que dominem modos de recolher informação, de tratá-la e torná-la operativa; que dominem áreas que lhes permitam também adquirir ferramentas que os ajudem a fazer um diagnóstico ambiental em todas as suas vertentes.

Para encerrar este tema buscamos retomar e refletir sobre vários conceitos definidos sobre meio ambiente com os vários autores.

\subsubsection{A construção do conceito de Educação Ambiental pelos docentes do} curso de Gastronomia.

Preparamos uma apresentação de imagens relacionadas ao tema ambiental visando à interpretação de cada participante frente às mesmas, objetivando formar a construção do conceito de educação ambiental, além de despertar a percepção deles, através das sensações frente às figuras e da interpretação das mesmas em relação à educação ambiental.

Num primeiro momento os professores se preocuparam em descrever as sensações pessoais, ressaltando as emoções, percepções e vivências de cada um, no que se refere ao passado e ao presente. Surgiram então, sensações e experiências de outras épocas, experimentadas por cada um deles, em outro estágio de vida, mas que certamente contribuíram para a formação pessoal e profissional de cada um. Eles buscaram compreender durante as discussões, atitudes e costumes adquiridos atualmente.

Apresentamos ao grupo a figura de uma paisagem representada pelo pôr do sol e observamos que enquanto para alguns essa imagem retratava uma sensação boa de dever cumprido, de paz e relaxamento, para outros do grupo a imagem expressava stress e cansaço.

Outra figura apresentada foi uma foto de um lixão que chocou o grupo. Embora a figura fosse comum como todas as demais de um lixão, a cidade de Águas de São Pedro não tem lixão e, talvez por eles não estarem acostumados com essa imagem, 
expressaram a sensação de abandono, de exclusão social, apesar de não haver nenhuma imagem de pessoa na foto.

Dentre as 12 fotos apresentadas para o grupo durante a aula, foram selecionadas apenas três (03) para serem citadas no texto, a fim de evidenciar a percepção do grupo, conforme abaixo:

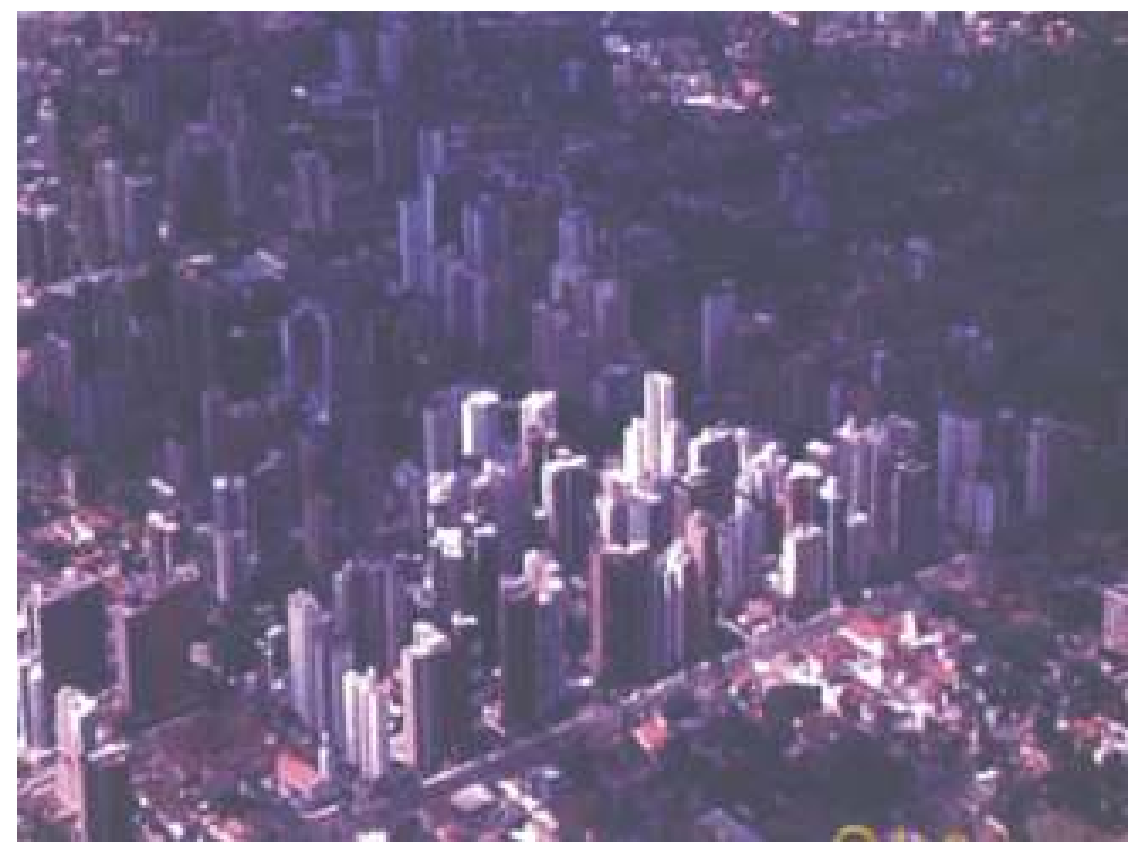

Figura 3: Construção do conceito de Educação Ambiental - Área Urbana

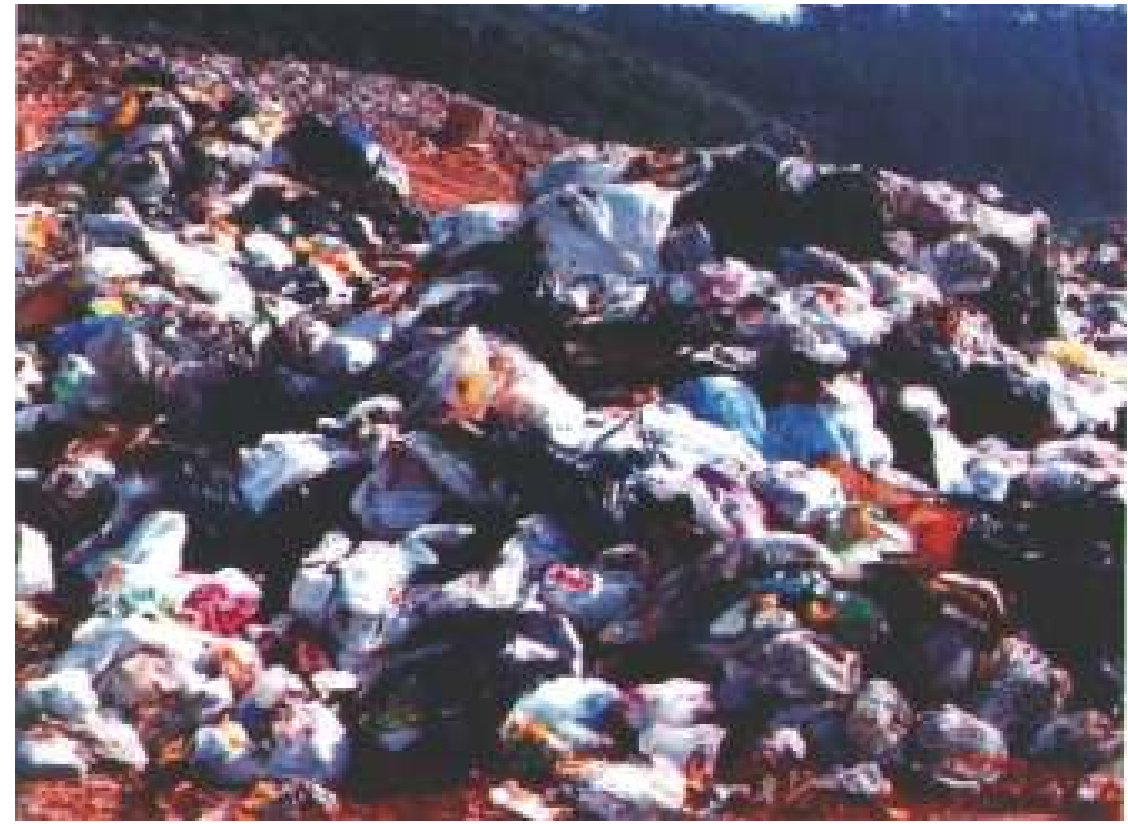

Figura 4: Construção do conceito de Educação Ambiental - Depósito de lixo 


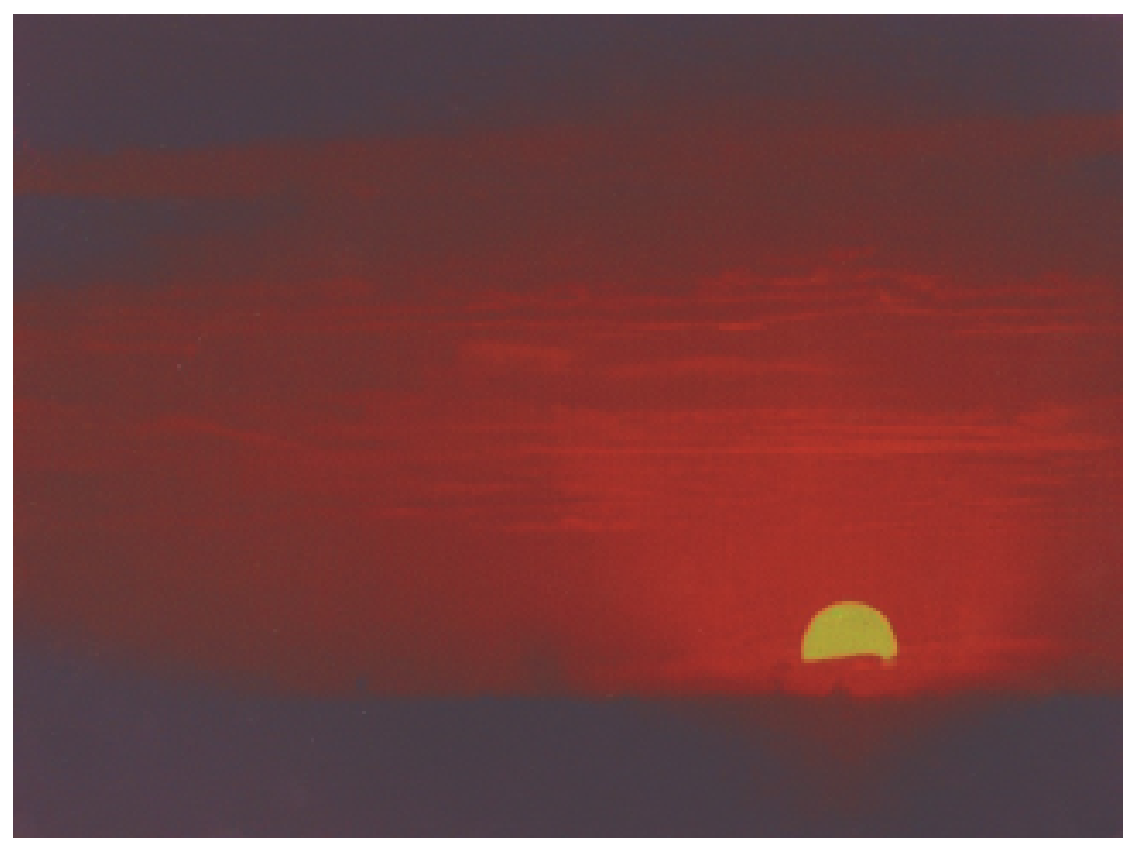

Figura 5: Construção do conceito de Educação Ambiental - Pôr do Sol

Outra imagem interessante que apresentamos para o grupo foi a de um conjunto de prédios com vista aérea. Para alguns professores a imagem causava a sensação de poluição, sufoco; para outros de deserto, rochedo; para outros, ainda, a sensação de modernidade.

Dessa forma, buscamos vincular tais sensações pessoais à bagagem individual de cada um e encontramos um consenso, que a educação ambiental é um processo que forma o indivíduo a partir de muitas vivências e concepções ao longo da vida de cada um.

Durante o debate surgiu de cada um, espontaneamente, a articulação das figuras, das sensações e do meio ambiente. Finalmente, atendendo o nosso objetivo, as aulas desenvolvidas por cada um deles frente à educação ambiental no curso de cozinheiro, propiciaram que os participantes transportassem para a prática docente individual toda a sensação vivenciada por cada figura por nós apresentada.

A troca de informações e de vivências pessoais motivou todos a participar. Pareciam estar percebendo algo de que nunca se deram conta, principalmente de que a educação ambiental sempre estivera presente na vida toda deles. Isso favoreceu uma grande motivação pessoal frente ao debate.

Segundo LEME (2006), as trocas propiciam o fortalecimento do grupo, pois os participantes acabam compartilhando as mesmas dificuldades e construindo soluções 
coletivamente. Esse processo promove valores, como a solidariedade, a cooperação e a co-responsabilidade diante das decisões tomadas.

Solicitamos, então, aos participantes que trabalhassem individualmente na elaboração da definição de educação ambiental.

Citaremos algumas que julgamos interessantes, a fim de discutirmos o universo dos profissionais envolvidos, como exemplo, na formação ambiental até aquele momento, uma vez que ainda estávamos somente ouvindo e observando para, posteriormente, desenvolvermos um trabalho na área de atuação de cada um frente às questões voltadas para o meio ambiente e às práticas posteriores de educação ambiental, conforme já mencionado anteriormente.

Uma das definições de educação ambiental apresentadas refere-se à “Orientação, preservação, prevenção e controle de qualidade". A orientação faz parte do papel docente; a preservação e a prevenção contribuem para a continuidade do desempenho profissional na área gastronômica; quanto ao controle de qualidade as empresas que atuam na área de serviços prezam por essa questão, pois esse item tornouse um diferencial nas empresas, incluso o SENAC, que possui as certificações conhecidas como ISO 9002 (área de serviços) e ISO 14000 (meio ambiente).

Outra definição apresentada foi a "Cultivação, preservação, conscientização, preservando o meio ambiente e proporcionando um alivio", sendo que o cultivo e a preservação são formas de manter aquilo que já temos, a fim de sobrevivermos; quanto à preservação é a garantia da sustentabilidade, para termos sempre, de forma que não sature o meio natural.

Uma terceira definição de educação ambiental que surgiu ao longo dos debates foi a de um "Processo que analisa formas diferentes de gerir, conservar e preservar o ambiente. Planejar de maneira adequada a globalização através de um desenvolvimento sustentável'. Tal definição nos mostrou abertura para a busca de novos caminhos para garantir a preservação e manutenção do meio natural, de forma que certos procedimentos pudessem garantir essa nova estratégia de gerir, buscando um uso sustentável que possa suprir as necessidades do ser humano. Entretanto, as necessidades e o bem-estar da sociedade estão interligados à educação, saúde, água de qualidade, ar puro, e beleza natural. Se pensarmos que todos esses quesitos estão atrelados à economia e a ecologia, estas estão cada vez mais entrelaçadas, numa rede de relações possíveis de se pensar a sustentabilidade (TRISTÃO, 2004). 
A partir da reflexão individualizada e da explicação de cada um na construção do seu conceito pessoal, pedimos ao grupo para que se reunisse para elaborar uma única frase, uma vez que eles já haviam refletido e debatido a respeito do assunto em questão. O objetivo da frase elaborada pelo grupo é que a mesma se configurasse como sendo a definição que futuramente irá balizar a reestruturação da grade curricular do curso de cozinheiro com a inserção do tema ambiental nas aulas de cada professor presente.

Neste momento o grupo pareceu seguro e as argumentações que surgiram foram discutidas calmamente e embasadas em leituras anteriores feitas por eles com iniciativa própria. O grupo debateu bastante, o que proporcionou um amadurecimento amplo na reflexão da questão ambiental, de forma que houve uma imersão de cada um no tema em questão, contribuindo para o fortalecimento do assunto dentro da vida pessoal e profissional dos participantes, não se restringindo apenas ao papel operacional da área gastronômica, mas também ao papel do educador enquanto articulador e até mesmo formador de opinião frente aos seus alunos.

Assim, o conceito de Educação Ambiental elaborado pelo grupo foi:

"Processo que analisa formas diferentes de gerir com o objetivo de: cultivar, conscientizar, orientar, preservar $e$ controlar a qualidade. Planejar de maneira adequada a globalização por meio de um desenvolvimento sustentável”.

Durante a elaboração da frase pudemos perceber a defesa de cada um em relação ao seu ponto de vista na elaboração de uma única frase, bem como a exposição de suas muitas visões sobre o tema. Percebemos que para contemplar todos os aspectos discutidos, o grupo elaborou uma definição que pudesse contemplar a todos os participantes, gerando assim uma "colcha de retalhos".

Para finalizar o encontro, demonstramos algumas definições de alguns autores sobre as quais eles refletiram, elegendo aquela com que mais se identificaram. Deixamos a apresentação das definições dos autores para o final do encontro, afim de não influenciarmos na elaboração da definição do grupo.

As definições de Educação Ambiental e os autores citados que apresentamos para o grupo foram as seguintes:

"É um processo de aprendizagem permanente, baseado no respeito a todas as formas de vida. Tal educação afirma valores e ações que contribuem para a transformação humana 
e social e para a preservação ecológica. Ela estimula a formação de sociedades socialmente justas e ecologicamente equilibradas, que conservam entre si relação de interdependência e diversidade. Isto requer responsabilidade individual e coletiva em níveis local, nacional e planetário" (Tratado de Educação Ambiental para Sociedades Sustentáveis e Responsabilidade Global, 1992).

"É entendida como uma educação política, no sentido de que ela reivindica e prepara os cidadãos para exigir justiça social, cidadania nacional e planetária, autogestão e ética nas relações sociais e com a natureza" (REIGOTA, 1996).

"O objeto da educação ambiental não é o meio ambiente como tal, mas sim a nossa relação com ele" (SAUVÉ, 2003).

"Processos por meio dos quais o indivíduo e a coletividade constroem valores sociais, conhecimentos, habilidades, atitudes e competências, voltadas para a conservação do meio ambiente, bem de uso comum do povo, essencial à sadia qualidade de vida e sua sustentabilidade" (Política Nacional de Educação Ambiental, artigo $1^{\circ}$, 1999).

"A educação ambiental, na educação escolar deve ser desenvolvida no âmbito dos currículos das instituições de ensino públicas e privadas, englobando:

I-Educação básica:

$a$ - educação infantil

$b$-- ensino fundamental

$c$-ensino médio

II - Educação Superior

III - Educação Especial

IV-Educação Profissional

$V-$ Educação de jovens e adultos".

(Política Nacional de Educação Ambiental, artigo 9º, 1999). 


\subsubsection{A questão ambiental e o profissional da gastronomia - o uso de} recursos renováveis.

Buscamos abordar a inter-relação entre a prática operacional da atividade de cozinheiro, o meio ambiente e a educação ambiental.

Solicitamos, então, aos participantes que individualmente refletissem sobre as atividades cotidianas que ocorrem dentro da atividade prática desenvolvida no setor da especialidade de cada um deles, assim: legumeria, açougue, confeitaria, garde-manger e cozinha central.

A reflexão deveria estar pautada nas definições da aula anterior com relação aos conceitos de educação ambiental e meio ambiente o qual o grupo concluiu, e pelas definições de vários autores apresentadas em sala de aula por nós.

A partir de reflexão e anotações, cada participante deveria expor a sua abordagem de forma que a mesma retratasse, como dissemos anteriormente, vivências práticas dos professores frente aos alunos.

Cada um, individualmente, fez a sua apresentação, que resultou em um debate interessante e gerou reflexões pertinentes ao papel de professor. Uma das questões que pudemos observar durante os encontros é que esses professores têm uma formação exclusivamente voltada à atuação operacional. Aliás, a própria característica do curso de cozinheiro faz com que eles se distanciem da reflexão, da leitura e da pesquisa. Acreditamos, assim, que o presente curso auxiliou o exercício de ouvir, processar a informação e refletir a respeito do assunto discutido.

Uma abordagem interessante foi a respeito da etiquetagem do pré-preparo dos alimentos, de forma que, as bandejas de legumes, carnes, caldos, cremes, massas dentre outras, são pré-preparadas e minuciosamente etiquetadas com datas, para que os outros setores consumam sempre os alimentos pré-preparados mais velhos, considerando que cada alimento tem uma tolerância de tempo para ser consumido.

A cozinha quente é o setor responsável pelo preparo final do prato, mas há um pré-preparo dos alimentos antes do mesmo ir para a organização final. A legumeria é responsável pelos legumes e verduras, que servem para confeccionar pratos da entrada, as saladas, caldos ou cremes e as guarnições que servem como complemento do prato.

O açougue é responsável pela preparação de carnes bovinas e/ou suínas, aves e peixes, sendo que cada preparação tem sua gramagem e padrão de tiragem, encaminhamento das aparas, higienização, embalagem, tempero e recheio das carnes. 
São preparados neste setor, armazenados e etiquetados para o consumo da cozinha quente que, como dissemos anteriormente, é responsável pelo preparo final do prato.

A cozinha quente é um setor que conta com profissionais ágeis. Os alunos quando passam por esse setor devem buscar adquirir três quesitos básicos: organização, agilidade e, finalmente, padronização no preparo dos pratos quanto ao sabor e a apresentação final do mesmo.

A agilidade é o quesito mais sensível deste setor, uma vez que ele busca atender ao cliente que está "normalmente", com fome, à espera do prato e, devido à pressa, segundo os participantes, os profissionais deste setor não respeitam a data de validade dos alimentos. Além disso, na maioria das vezes misturam carnes brancas com carnes vermelhas, gerando desperdício, pois, os alimentos brancos acabam absorvendo o sangue dos alimentos vermelhos e tendo que ser desprezados e descartados antecipadamente.

Isso acontece com freqüência, principalmente porque gera um trabalho grande para o setor responsável pela organização desses alimentos, seja no açougue ou na legumeria. Os alunos que passam pelas etapas iniciais do curso ficam responsáveis pela higienização e organização final deste setor, gerando um descompromisso dos setores mais avançados na etapa do curso. Ou seja, a cozinha quente, a confeitaria e o gardemanger, despertam uma "revanche" entre os alunos e, com isso, os aprendizes das etapas superiores do curso acabam descontando sempre nos mais novos.

O interessante é que os professores relatam dizendo:

"Eu já passei por isso, agora os novos alunos é que vão ter que passar, pra sentir na pele!”

Os professores da atividade prática sabem dessas questões, mas não as trabalham com os alunos para mostrar-lhes o desperdício que há com os alimentos, nem tampouco buscam zelar pela solidariedade dentro dos departamentos da cozinha. Com isso, o trabalho efetuado pelos professores em sala de aula para a conscientização e gravidade do problema fica esquecido quando esses mesmos alunos vão para a prática profissional do curso.

Assim, o que percebemos são valores competitivos e individualistas que fazem parte da formação profissional do aluno, uma vez que os educadores deveriam despertar nos futuros profissionais um sentimento de solidariedade e cooperação. 
Aprender a ser professor é um processo de formação que tem início e não tem fim (...), portanto não existe professor acabado, pronto, o processo de formação acadêmica em educação ambiental é uma trajetória permanente e de construção coletiva (TRISTÃO, 2004).

Outro item discutido por nós e ressaltado pelos professores é em relação à elaboração do cardápio do restaurante do hotel.

O cardápio estipulado pelo chefe de cozinha e executado pela sua brigada é composto por pratos elaborados e que contam com uma apresentação belíssima, embora os cortes utilizados para a confecção dos pratos - tanto no que diz respeito aos legumes, verduras e carnes - são cortes difíceis e que demandam tempo e técnica, gerando muito treinamento por parte dos aprendizes. Dessa forma, o que se percebe é um grau de desperdício elevado, pois os cortes elaborados são artesanais, geram muitas aparas, que na maioria das vezes não têm aproveitamento, sendo, então, desprezadas.

$\mathrm{O}$ ideal seria que o chefe master da cozinha elaborasse um cardápio que tivesse menos desperdício durante o seu pré-preparo. Isso, porém, traria uma desvantagem aos alunos: a de não terem a oportunidade de treinar os cortes de maior elaboração, técnica e destreza profissional. Além dos pratos os pratos teriam uma montagem simples, sem o "glamour" que os hóspedes que freqüentam o hotel-escola esperam.

$\mathrm{O}$ ideal seria que fizessem um cardápio que buscasse atender tanto aos hóspedes, como aos alunos, além de atender também aos princípios da educação ambiental, o que aparentemente parece ser difícil.

O importante neste contexto seria a busca de uma mudança de paradigmas visando despertar uma nova concepção de conforto, de "glamour" e de "status", de forma que esta não estivesse pautada no consumismo, no desperdício e principalmente na fartura desmedida.

A proposta, nesse caso, foi a de haver uma mudança dentro do hotel-escola SENAC em que todos os envolvidos que por ali passassem, seja na função de aluno, estagiário, funcionário ou hóspede, pudessem vivenciar um ambiente voltado para novos valores frente às questões da educação ambiental, de forma que todos, tomados por uma nova concepção de vida e de valores, fossem sensibilizados a repensar seus padrões de vida cotidiana, mesmo porque a função do SENAC não é comercial e sim educacional, firmando-se, assim, o seu compromisso com a sociedade.

Esta nova concepção deveria envolver alunos, professores, chefes do hotelescola e também os hóspedes, buscando propiciar um novo estilo de "conforto" de 
forma que atenuasse uma nova visão de mundo, de satisfação pessoal e finalmente novas atitudes.

Segundo TRISTÃO (2004), há um desafio a ser enfrentado, que está focado na possibilidade das instituições e dos sistemas de informações sociais se tornarem facilitadores de um processo que reforce os argumentos para a construção de uma sociedade sustentável, na busca de um exercício de cidadania ativa e na mudança de valores individuais e coletivos.

Um novo hábito foi mencionado durante o workshop, que deveria ser trabalhado pelos professores da atividade prática, e que é nitidamente trabalhado em sala de aula pelos professores e incorporadas inicialmente, pelos alunos, mas que se perde ao longo do curso. É a questão da energia elétrica, como o descaso com a atitude de apagar as luzes nos intervalos dos setores, ou seja, durante os períodos de ociosidade do mesmo, durante o turno de atividade, que ocorre durante o horário do almoço, intervalo para o café e para as aulas teóricas.

Uma nova observação foi levantada durante a discussão em que a estocagem de sobras dos alimentos deveria ser revista, para que estes pudessem ser adequadamente dispostos nas câmaras frias, ou seja, condizentes com as temperaturas pertinentes aos diversos tipos de alimentos. É comum ocorrer no setor de cozinha quente - que se cerca de vários alimentos pré-prontos visando à agilidade do preparo do prato - quando há devolução da sobra do alimento não utilizado, que ainda está em perfeito estado de utilização, não há cuidados com a temperatura de rearmazenamento do mesmo para que possa ser reutilizado, o que o torna totalmente descartável e, conseqüentemente, desperdiçado.

Durante o debate com os participantes, a equipe de funcionários e professores da cozinha, assim como os gerentes, deveriam adotar uma nova conduta quanto à determinadas decisões no que se refere ao destino e ao desperdício dos alimentos, considerando que esta seja uma filosofia que deva ser praticada de "ponta a ponta" na hierarquia do hotel escola.

Neste contexto, a educação ambiental aponta propostas pedagógicas centradas na conscientização, mudança de comportamento, desenvolvimento de competências, capacidade de avaliação e participação dos professores, propiciando o aumento de conhecimentos, mudança de valores, e aperfeiçoamento de habilidades (TRISTÃO, 2004). 
Este fato foi mencionado devido a uma ocorrência na semana anterior a essa reunião, e que tinha gravemente tocado aos professores. É muito comum um ou outro gerente passar pelo setor de atividade produtiva da cozinha onde atuam alunos de diversos níveis dos cursos, estagiários de empresas e de outras faculdades e, numas dessas ocasiões, um gerente demonstrou uma conduta contrária a que queremos construir no hotel escola. Quando o mencionado gerente passou pela cozinha e se dirigiu até as áreas sociais do hotel-escola para supervisionar o buffet do almoço do sábado $^{17}$, várias porções de pastel já tinham sido servidas e o referido gerente degustou um deles a fim de supervisionar a qualidade do alimento confeccionado. Embora todos julgassem que estavam de acordo com os padrões do hotel SENAC, e que o mesmo já tinha sido passado pela aprovação do chefe "master", o gerente não aprovou a textura da massa do pastel. Com isso, foi até a padaria e argumentou com o professor responsável pela confecção do alimento. O responsável respondeu que a espessura da massa é a determinada pelo chefe, sendo sempre utilizada a mesma, a fim de manter a padronização do alimento e, principalmente, é a própria que se sucede ao longo de anos.

$\mathrm{O}$ gerente, não convencido de que se mantivera naquele momento a padronização, nem que a massa havia sido inspecionada anteriormente pelo chefe de cozinha, pediu que retirassem o alimento do restaurante e que toda a massa fosse descartada e jogada no lixo.

As pessoas envolvidas no processo argumentaram, mas em vão. Sugeriram que o alimento já confeccionado fosse encaminhado para o refeitório dos alunos e funcionários, uma vez que estava em ótimo estado e que tinha acabado de ser confeccionado, mas ainda assim não o convenceram, e com isso, o alimento foi para o lixo.

Quando finalmente chegaram a uma definição sobre a nova confecção do alimento a ser produzido, o gerente deixou a padaria para que o cozinheiro e os alunos fizessem, então, uma massa mais "leve", segundo o gerente, de forma que ficasse mais fina e mais crocante.

${ }^{17}$ Este buffet é composto da tradicional feijoada, além de um cardápio à parte para aqueles que não apreciam o prato do dia, sendo que de entrada, o hotel-escola serve um farto bufê de saladas e molhos frios e o caldo de feijão quente, além de batidinhas e aperitivos, dentre eles o mini pastel de carne que é confeccionado na própria padaria do hotel por alunos, professores e cozinheiros. 
O cozinheiro em questão orientou os alunos para que retomassem a execução do alimento, mas sem alterar a textura da massa, refazendo o alimento igualmente ao que tinha sido preparado anteriormente e assim o fizeram, em sigilo, quanto ao padrão da massa.

Quando terminaram a confecção da suposta "nova" textura da massa do pastel chamaram o gerente envolvido no assunto para experimentar se o mesmo aprovava o "novo alimento" feito segundo as "ordens" dele.

Qual foi a surpresa do grupo quando o mesmo aprovou a segunda tiragem, não percebendo que a tão criticada massa confeccionada anteriormente era a mesma a qual havia reprovado.

O que se percebe é que há uma filosofia da escola, voltada para valores que permeiam princípios da educação ambiental, mas que não se estendem às áreas operacionais do hotel. Muitas vezes parece que estamos em duas instituições completamente diferentes, que promovem diferentes valores e atitudes, gerando um desconforto entre os próprios profissionais do hotel-escola, além de uma confusão de comodismo e de valores relativos aos alunos, o que compromete a qualidade da formação de futuros profissionais, que poderão repassar atitudes incorretas nos seus postos de trabalho, quando estiverem atuando no mercado.

Os professores reconheceram que quando se trata de questões ambientais que envolvem mudança de hábitos, valores e desenvolvimento de habilidades, faz-se necessário um trabalho persistente e continuado com os alunos e com os próprios funcionários do hotel. Eles reconheceram a necessidade de estarem trabalhando constantemente com a temática.

Esses professores destacaram também a importância de sempre recomeçar o processo educativo, já que sempre haverá novos alunos. Essa preocupação, antes dos encontros não acontecia, pois como eles mesmos mencionaram, a informação ficava solta, sem efetividade e coerência, já que era trabalhada com um grupo de alunos e não necessariamente com o outro. Assim, a visão da educação ambiental era pautada em um paradigma reducionista, com conhecimentos fragmentados.

Outra questão ressaltada pelo grupo foi a do lixo que deveria ser depositado em caçambas separadas. Mas a separação não é uma atitude freqüente desempenhada pelos alunos, nem tampouco pelos profissionais da cozinha, pois a pressa inimiga desse hábito de separação e classificação do lixo, uma vez que, na correria, o lixo é depositado dentro de uma única lixeira, sem critério algum. 
Segundo os professores, o fato de dos funcionários depositarem o lixo em uma única caçamba não os deixa em nenhum momento de "consciência pesada", uma vez que quando eles separam o lixo e o levam para a área de armazenamento, a pessoa responsável pelo armazenamento do mesmo o deposita em um único recipiente, misturando, assim, aquilo que já fora anteriormente separado.

A pessoa responsável pela coleta do lixo dentro do hotel-escola desconhece a possibilidade de reaproveitamento dos resíduos, e com esse péssimo exemplo, serve de desmotivação em relação aos cuidados do encaminhamento do mesmo.

O ideal seria que o SENAC doasse os resíduos para pessoas da área que tivessem o comprometimento de encaminhá-lo para a devida a coleta e posterior triagem do mesmo, servindo de "modelo" para os futuros profissionais que atuarão no mercado de trabalho.

\subsubsection{Desperdício, reaproveitamento, lixo e reciclagem na cozinha}

Promovemos o encontro de uma palestrante da USP de São Carlos/SP responsável pelo programa USP-Recicla ${ }^{18}$, com o grupo de participantes a fim de enriquecer o debate a respeito dos temas: desperdício, reaproveitamento, lixo e reciclagem na cozinha.

O programa desenvolvido durante o curso foi estruturado a partir das necessidades mencionadas junto aos participantes. Buscamos, com a palestra, que o assunto fosse abordado de forma genérica os pontos discutidos nos encontros anteriores, a fim de relacioná-los, para que houvesse um "fechamento" dos tópicos em questão.

A palestra foi amplamente divulgada pela coordenação do curso e, com isso, tivemos a presença de vários profissionais da área operacional do hotel-escola, além do chefe master, o que possibilitou naquele momento a reavaliação de diversos procedimentos.

Este encontro foi proposital, buscando abrir uma reflexão de educação ambiental de tal forma que os participantes não se restringissem somente à sua atividade profissional, mas que se pautassem principalmente em questões voltadas para uma ação reflexiva que fosse além do seu ambiente de trabalho, ampliando, então, a sua reflexão.

\footnotetext{
${ }^{18}$ Departamento que faz a divulgação e o treinamento das pessoas de diversos níveis de instituições de ensino, empresas das mais variadas categorias e ações diversas com relação à redução de consumo, ao reaproveitamento e reutilização dos materiais.
} 
Dessa forma, orientamos para que fossem abordados pontos já anteriormente mencionados pelo grupo, mas de forma genérica, de maneira a fixar as informações já antes debatidas, além de ampliar o foco de visão dos participantes, de forma que os levassem a perceber os problemas com outra concepção ou teor.

A principal questão levantada pela palestrante foi no que diz respeito aos aspectos adequados e inadequados do encaminhamento do lixo, já que o acúmulo de lixo é o resultado de um fluxo contínuo de materiais biodegradáveis e recicláveis produzidos, como, por exemplo, alimento e matérias-primas.

Segundo SCHALCH e LEITE (2000), os resíduos podem se agrupar em três áreas de estudo: resíduos sólidos domiciliares, resíduos de serviços de saúde e resíduos sólidos industriais. Os resíduos gerados em uma cozinha comercial, como a do hotelescola SENAC de Águas de São Pedro, enquadram-se na categoria de resíduos sólidos domiciliares. A enorme quantidade de resíduo gerado diariamente nas três categorias é alarmante e se constitui em um grande problema, pois é uma séria ameaça ao homem e ao meio ambiente. Há espaços ou cidades em que a coleta, o transporte e o encaminhamento do lixo resultam no depósito deste em córregos e terrenos baldios, ao invés de locais mais adequados. Segundo ainda os mesmos autores, no que diz respeito ao tratamento, reaproveitamento e disposição final de resíduos, a situação é alarmante, pois, na grande maioria das cidades brasileiras despejam-se os resíduos nos chamados “lixões”, espaços que, desprovidos de critérios sanitários e ecológicos, não devem ser confundidos com aterros sanitários.

Contudo, o questionamento que a palestrante traz em plenária para o grupo é com relação aos recursos esgotáveis e não renováveis para a produção de matéria-prima, que sem esta não há possibilidade de atuação profissional na área gastronômica.

Outro tema debatido foi a satisfação pessoal pautada no consumismo, imposta pela mídia para atender à sociedade capitalista;

$\mathrm{Na}$ realidade, a crise global nos leva a uma crise de esgotamentos, não somente de recursos naturais renováveis e não renováveis, mas também de valores éticos, de problemas sociais, ao agravamento da pobreza mundial. Percebemos que o grupo estava atento e indignado com tais colocações, o que resultou em reflexões pessoais que não ocorrem usualmente, uma vez que no dia-a-dia acabam imersos nos seus afazeres e "lutam contra o relógio", como todos nós. 
Os valores da sociedade em geral estão voltados para o modelo capitalista, centrado em uma cultura da "descartabilidade", do desperdício e da competição do convívio entre os seres humanos e a natureza.

Sugerimos ao grupo que fizesse, individualmente, uma avaliação reflexiva de cunho pessoal e profissional quanto aos quesitos acima mencionados, pautado nesta "nova cultura da sociedade".

Percebemos um silêncio na sala, acrescido de algumas falas como "sentimento de culpa", "aquisição material, mais do que realmente necessitam", "no dia-a-dia não há reflexão sobre a questão".

No entanto afirmamos que a educação pode transformar essa "domesticação" na qual estamos inseridos, resultando-nos em "seres humanos" formatados, levando à miséria e à exclusão social.

A educação ambiental luta contra essas condutas e busca agregar nas pessoas conceitos, como já vimos anteriormente, pautados no respeito e na solidariedade, dentre outros.

Levamos o grupo a refletir sobre se a educação de cunho geral possibilita a adesão de novos valores e uma reformulação de conduta; se os professores ali presentes poderiam contribuir para uma nova atitude a partir dos seus alunos e de novas formas de vida.

Percebemos o grupo reflexivo e interessado na palestra. A educação pode criar formas de agregar novos valores nas pessoas, novas habilidades e capacidades para orientar a transição em direção à sustentabilidade (LEFF, 2001).

Após a palestra, abrimos um espaço para um debate com o grupo, a fim de fazermos um fechamento dos assuntos discutidos até então, e nos direcionarmos para uma discussão focada na realidade cotidiana dos participantes.

O grupo de professores mencionou que a separação do lixo é feita de forma eficiente pelos profissionais da cozinha, sendo que quase $90 \%$ do mesmo é separado, restando somente $10 \%$ para se alcançar à eficiência total (esses $10 \%$ restantes se atribui à pressa no atendimento ao cliente). Mas, segundo os participantes, e como já visto anteriormente, é desestimulante o empenho do grupo do setor de Alimento e Bebidas ${ }^{19}$, já que o lixo é recolhido por faxineiros que acabam por misturá-lo totalmente - e se isso

${ }^{19}$ Refere-se hierarquicamente a uma gerência responsável pelas áreas do hotel que manipulam todos os alimentos e todas as bebidas, cujos setores são: restaurantes, cambuza (setor responsável pelo 
não ocorre dentro das dependências do hotel-escola, ocorrerá posteriormente pela empresa que coleta o lixo.

A cozinha industrial, que é responsável por uma grande quantidade de preparação diária de alimentos visando atender aos alunos, estagiários e funcionários do hotel-escola, adotou a prática de ensacar os talheres com o plástico - o que usualmente gera uma discussão, segundo a palestrante, entre os ecólogos ou a camada da população preocupada com a questão ambiental e as nutricionistas, que defendem a teoria da higienização e garantia de que muitas pessoas poderão ter contato manuseando os esses utensílios.

Uma conduta ambientalmente mais adequada dispensaria o uso da embalagem dos talheres, uma vez que tal procedimento gera maior quantidade de resíduos, não acrescentando nada em termos de higiene e conforto ao comensal, que irá utilizar somente de um jogo de talher ${ }^{20}$ para cada refeição.

$\mathrm{Na}$ questão do consumismo, verifica-se uma discussão em torno da mídia e do capitalismo, em que nos pautamos nos três Rs: reduzir - o consumo e o desperdício; reutilizar - objetos e materiais; e reciclar - materiais.

Outra questão abordada pelo grupo foi em relação à necessidade da utilização de matéria-prima de boa procedência e com o registro no órgão-oficial, além da atenção à data de fabricação, ao prazo de validade e à maneira correta de conservação.

Os produtos refrigerados também tiveram um destaque especial na pauta da nossa palestra. Observou-se que devem estar à temperatura adequada (até $7^{\circ} \mathrm{C}$ para refrigerados e $18^{\circ} \mathrm{C}$ para os congelados).

Enriquecendo a palestra e atendendo aos participantes que estavam sedentos de informação e altamente participativos, abordamos algumas regras básicas para o consumo de alimentos com qualidade, tais como:

- utilização de matéria-prima de boa qualidade;

- cozimento adequado dos alimentos (algo que, segundo observamos, é muito bem feito no hotel-escola);

- consumação imediata dos alimentos (o que nem sempre é executado pelo hotelescola, pois quando há sobra de preparados, estas demoram dias para serem encaminhadas ao refeitório, a fim de proporcionar um reaproveitamento das mesmas);

armazenamento de bebidas alcoólicas e não alcoólicas), adega, bares, copa (setor responsável pelo serviço de café), cozinha, confeitaria, garde-manger, açougue, padaria, cozinha industrial.

${ }^{20}$ Inclui garfo, faca e colher de sobremesa. 
- conservação adequada dos alimentos cozidos;

- técnicas de reaquecimento dos alimentos anteriormente cozidos (quanto a este item e ao anterior, não sentimos um preparo dos professores e dos profissionais presentes, o que nos leva a crer que o hotel-escola carece de informações e treinamentos para os seus funcionários neste quesito);

- cuidados com o contato entre alimentos cruz e cozidos (este item é primordial no hotel-escola, uma vez que os departamentos atuam separadamente);

- higiene na manipulação dos alimentos (esta questão é muito cobrada por parte dos professores, seja em sala de aula, em salas de laboratório ou em setores operacionais do hotel-escola);

- limpeza dos setores da cozinha (esta é devidamente executada, não somente pelos responsáveis por esta atividade - no caso os copeiros e faxineiros - mas também pelos ajudantes de cozinha, pelos alunos, pelos professores e pelos chefes dos departamentos da cozinha.

- Uso de água tratada (algo usual no SENAC).

O chefe master ressaltou que o SENAC tem uma CIPA $^{21}$ - Comissão Interna de Prevenção de Acidentes, que tem por objetivo desenvolver atividades voltadas não somente à prevenção de acidentes do trabalho, mas também para a proteção da saúde dos trabalhadores, diante dos riscos existentes nos locais de trabalho.

Os participantes ficaram motivados com a palestra e a preocupação com a área de gastronomia incomodou a cada um deles, de forma que os mesmos tornaram-se reflexivos em torno do assunto discutido, uma vez que podem, através dos seus hábitos, contribuir com o meio ambiente por meio de uma revisão de hábitos cotidianos.

Segundo TRISTÃO (2004), as práticas ambientais só serão possíveis se estiverem inseridas no contexto de valores sociais, mesmo que se refira à mudança de hábitos cotidianos.

Sentimos que a palestra propiciou também uma revisão geral e pessoal em cada um dos participantes, além de uma indignação em relação ao comportamento cotidiano do ser humano de forma geral, sendo que este comportamento tem reflexo direto no meio ambiente.

21 As atribuições da CIPA, bem como a sua organização podem ser consultadas nos dados internacionais de catalogação na publicação (CIP) contidas nas orientações para o comércio varejista de carnes - São Paulo: SENAC - SP, 1993. Carnes - Indústria e Comércio. 
Pudemos sentir, já que os próprios participantes manifestaram, um certo desconforto, quando eles puderam avaliar o quanto eles próprios podem contribuir para uma mudança de mentalidade e conseqüentemente de atitude, que propicie uma nova conduta, não somente deles mesmos, mas dos seus alunos, colegas de trabalho, filhos e até mesmo dos seus superiores, buscando uma nova relação com o meio ambiente.

\subsubsection{Consumo responsável}

Para discutirmos o tema consumo responsável, trouxemos uma ecóloga que é responsável pelo grupo que coordena o projeto chamado de Consumo Solidário - que visa promover a inclusão social no que diz respeito ao processo de produção e de consumo $^{22}$.

A palestrante iniciou sua atividade descrevendo a função do ecólogo e permeando a responsabilidade de se trabalhar com questões voltadas para o meio ambiente, para o social e o econômico de uma população. Em seguida explicou sobre o projeto que coordena na Universidade Federal de São Carlos, que tem o objetivo de alavancar cooperativas de pequeno porte que atuam na cidade de São Carlos e região.

O projeto é chamado de "incubadora de cooperativas populares ${ }^{23}$ ", popularmente chamado de "SOL", pois se configura como solidário e tem por finalidade apoiar uma empresa de pequeno porte que está iniciando o seu negócio. Ela exemplificou que é comum trabalharem com empresas que produzem pão e derivados, hortaliças, refinadoras, dentre outras.

Uma das metas do consumo SOL é também buscar cadastrar o maior número de empresas possível que trabalhem com matéria-prima semelhantes, interessadas em um lote de aquisição maior do produto, visando a redução de custo e conseqüentemente gerando um produto final para o consumidor com um preço reduzido.

Como um exemplo deste trabalho podemos citar a época de comemorações natalinas, em que se verifica um aumento no consumo de farinha de trigo para confecção de panetones. A compra da farinha de trigo foi efetuada pela cooperativa coordenada por ela, que visava atender vários grupos que tinham interesse comum pelo

\footnotetext{
${ }^{22}$ Outras funções podem ser consultadas no site: http://geocities.yahoo.com.br/consumosol.

${ }^{23}$ A incubadora desenvolve outros projetos além do citado no texto, mas optamos por trabalhar este, por estar mais próximo dos objetivos propostos no workshop.
} 
produto. $\mathrm{O}$ custo foi menor e o panetone pôde ser comercializado por um preço mais acessível e, conseqüentemente, pôde ser consumido por uma parcela maior da população, de todas as camadas sociais. A cooperativa busca, também, alavancar novas empresas, gerando o maior número possível de empregos e reduzindo, com isso, o monopólio de empresas de grandes marcas, possibilitando a inserção de novas marcas no mercado e mais opções de escolha para o consumidor.

Os participantes mencionaram que a matéria-prima adquirida no Grande Hotel provém do CEASA ${ }^{24}$ de Campinas, que fica há aproximadamente $100 \mathrm{~km}$ da cidade de Águas de São Pedro.

Ressaltamos a preocupação que os professores presentes devem ter ao formar profissionais conscientes do papel de líderes em sala de aula e de formadores de opinião, no sentido de despertar a consciência nos alunos, pois estes serão os futuros profissionais que atuarão no mercado de trabalho. Os professores precisam não somente transmitir conhecimento e técnicas da profissão, mas também condutas, hábitos e opiniões na atuação profissional, dentro da área de hotelaria e mais especificamente de gastronomia, de forma que a escola se abra para o conhecimento, assumindo cada vez mais um caráter emancipatório.

No caso especifico da aquisição de matéria-prima julgamos que seria viável o incentivo de pequenos e/ou médios produtores do local ou região, visando à geração de emprego na localidade ou em cidades vizinhas, e conseqüentemente a diminuição da criminalidade local/regional - embora o município não apresente tais características.

Outro item relevante levantado por nós, foi em relação ao incentivo aos investimentos locais, para que estes possam ser revertidos em beneficio da própria população, não somente no que diz respeito à oferta de emprego e incentivo fiscal local, mas também pedagogicamente. O local poderia ser um atrativo de visitas técnicas, não somente para os alunos de diversos níveis de ensino do SENAC, mas também para outras escolas do município e região, contando ainda com o apoio da ESALQ/USP ${ }^{25}$, no sentido de parceria, para o desenvolvimento da atividade.

O município de Águas de São Pedro já tem uma vasta experiência em projetos pedagógicos e atua como receptor de diversos grupos com várias características e interesses. A cidade tem desde atrativos para a melhor idade - através dos banhos medicinais; para jovens - que buscam conhecer o mercado de trabalho na área de

${ }^{24}$ Centrais de abastecimento agrícola de São Paulo

${ }^{25}$ Escola Superior Luiz de Queiroz/ Universidade São Paulo 
"serviços" através do SENAC; para a idade infantil - que busca os recursos naturais e a tranqüilidade do município; bem como para jovens casais, que optam pela cidade objetivando seu romantismo.

Ainda referente à questão do cultivo da matéria-prima local, esta proporcionaria, dentre outros benefícios, a racionalidade do translado, que agrega custo ao produto e agressão ao meio ambiente, uma vez que há consumo de combustível. Além disso, a movimentação financeira na aquisição do produto ficaria no próprio município, não sendo desviada para outras localidades.

A participação do grupo foi intensa nesse sentido, gerando debate e reflexão, pois quando preparamos esta palestra não sabíamos que havia no grupo de professores ${ }^{26}$ um representante do poder legislativo municipal que se interessava por questões voltadas para o apoio à implantação de cooperativas em beneficio da população local. Enquanto integrante político e integrante do corpo docente do SENAC, o mesmo já havia levado aos superiores diversos projetos, que ainda não tinham sido executados, limitando-se somente a estudos.

A tomada de preço é uma preocupação evidente para a instituição SENAC, assim como para toda empresa privada. Assim, a prática dos compradores é de que, no mínimo, sejam requisitados orçamentos de 03 fornecedores distintos; caso contrário, a compra não deverá ser aprovada e conseqüentemente a matéria-prima não será adquirida, uma vez que os orçamentos passam pelo gerente responsável pela área de atuação $^{27}$.

Segundo os professores, há uma preocupação grande quanto à obtenção de matéria-prima e produtos em geral que tenham um custo reduzido, sem comprometer a qualidade, mas não há uma política de utilização racional, nem mesmo de reutilização dessa matéria-prima pela brigada de cozinha, restaurante e funcionários do hotel-escola. Afirmando essa questão, os participantes, exemplificam caracterizando o uso indiscriminado dos produtos e uma mentalidade latente em todos os funcionários de que o SENAC tem disponibilidade financeira para bancar os prejuízos. A impressão é de

\footnotetext{
${ }^{26} \mathrm{O}$ mencionado professor participou de 05 encontros e depois deixou a Instituição SENAC e o município de Águas de São Pedro, transferindo-se para o município do Guarujá.

${ }^{27}$ A área de hotelaria é composta por uma estrutura hierárquica densa, usualmente é composta por: gerente geral, gerente de alimentos e bebidas, gerente de hospedagem, gerente de lazer e eventos, gerente do setor de promoções e vendas do hotel e gerente administrativo.
} 
que algumas atitudes superiores desestimulam o uso racional de matéria-prima e produtos em geral.

Algumas afirmações são comuns nos corredores do hotel-escola, tais como:

“... o SENAC é rico, o SENAC pode”;

“...vamos testar essa nova receita, caso não dê certo, jogamos tudo e recomeçamos";

“... não precisamos apagar as luzes, podemos manter acessas, o SENAC pode pagar".

Os exemplos acima foram mencionados pelos professores durante o debate, que afirmaram ser muito difícil propor uma mudança de hábito e de mentalidade com os operacionais dos laboratórios e dos setores da cozinha do hotel-escola.

As aulas teóricas previstas na grade curricular do curso de gastronomia são desenvolvidas pelos profissionais que estiveram presentes no transcorrer de toda a nossa pesquisa, desde a sondagem prévia, os encontros previstos para a realização do workshop, até o final do projeto proposto na nossa pesquisa. Esses profissionais relataram, durante todo o nosso encontro, uma dificuldade latente, que é a dificuldade na transmissão de informações aos alunos, pois elas se tornam fragmentadas, uma vez que os professores envolvidos no nosso programa atuam teoricamente com os alunos, restringindo seu âmbito de atuação. Os profissionais diretamente envolvidos com os alunos na prática profissional dos departamentos do hotel-escola não partilham de hábitos, práticas e "filosofias" repassadas em sala de aula.

Essa mudança de atitude é algo lento, mas necessário segundo eles, pois sentem que aquilo que é repassado na teoria para os alunos está muito distante da prática do diaa-dia, dentro dos setores da cozinha, visto que não é exercitado pelos profissionais de cozinha, deixando para trás as informações absorvidas em sala de aula, pois os alunos se miram nos práticos da cozinha.

Uma evidência disso, segundo os participantes, é a não uniformidade do tratamento do lixo que, muitas vezes, conforme já mencionado anteriormente, é separado devidamente até uma parte do percurso; seu destino final é um recipiente único. A negligência não acontece, segundo eles, por maldade, mas sim pela pressa ou pela falta de informação sobre a relevância da separação e do exemplo de atitude para com os alunos, que observam atentamente todos os procedimentos, já que desempenham o papel de aprendizes. 
Segundo os professores, os alunos mencionaram que existem cuidados relevantes ao meio ambiente dentro dos diversos setores da cozinha, mas que não são praticados pelos demais setores, e assim sucessivamente.

Como exemplo disso pode ser citado o restaurante industrial, ou como é chamado dentro do hotel-escola, Restaurante de Alunos e Funcionários (RAF). Este é um setor que produz uma quantidade grande de alimentos - aproximadamente 1.000 refeições por dia entre almoço e jantar - pois todos os clientes internos do hotel-escola fazem as suas refeições neste restaurante, que tem sistema de bandeja e as pessoas se servem da entrada e da sobremesa.

Embora o cardápio da cozinha industrial seja completo, ainda é agregado a ele, as sobras do hotel, bem como também as sobras de preparados dos laboratórios gastronômicos e preparados em aula para aprendizagem dos alunos, que quando são em grande quantidade e não são consumidos totalmente, são encaminhados para o refeitório.

Segundo os participantes, há um desperdício grande neste setor, pois o cardápio é elaborado independentemente das sobras do hotel que são levadas para este restaurante, além das sobras dos laboratórios. Ambos setores que levam as sobras não têm um planejamento da produção culinária no que diz respeito à quantidade, e nem freqüência pré-determinada.

As sobras são dispostas para serem consumidas, mas segundo os participantes nem sempre são armazenadas em temperaturas adequadas, comprometendo a qualidade desses alimentos, pois eles também vêm para o setor de cozinha industrial já vulneráveis, devido ao seu tempo de vida útil.

Estes alimentos não são servidos caso estejam estragados, mas segundo os professores, às vezes estão no processo de deteriorização, ou com a apresentação final comprometida.

Indagamos ao grupo a razão pela qual os alimentos não são reaproveitados junto aos hóspedes, pois se eles estiverem em condições favoráveis de reutilização poderiam ser aproveitados, pois se não fazem mal aos funcionários e alunos, não fará mal também aos hóspedes.

Os participantes disseram que já houve uma investigação informal frente aos hóspedes e que os mesmos acharam uma atitude louvável a idéia do reaproveitamento dos alimentos, mas a referida idéia é concebível para os funcionários e alunos, e não para uma classe social privilegiada, que busca e paga por produtos de primeira linha, 
para quem a busca do prazer está vinculado ao lazer; para quem as férias estão pautadas na satisfação, incluindo nesta a gastronomia.

Segundo TRISTÃO (2004) estamos vivendo um risco global de civilização, quanto aos problemas ambientais, que engloba todas as raças, as etnias, as culturas e as classes sociais, devido à inserção das novas tecnologias e organizações sociais e de desenvolvimento. A mesma autora ressalta que a natureza é transformada em recurso, ou seja, em produtos consumidos por alguns, mas que todos arcarão com as conseqüências dos danos ambientais, ainda imprevisíveis.

Além disso, os valores estabelecidos pelo hotel para os hóspedes são de custo elevado, tanto para o SENAC de Águas de São Pedro e Campos do Jordão - que estão localizados no estado de São Paulo, como para os hotéis-escola do SENAC de outros estados, como o de Minas Gerais, Grogotó; e o do Espírito Santo, em Vitória (o badaladíssimo "Ilha do Boi").

A atitude do reaproveitamento parece uma idéia interessante, mas segundo o grupo desvinculado do contexto dos hóspedes, estes gozam de uma situação privilegiada, pois podem pagar para terem do "bom e do melhor", e não parecem estar preocupados com o reaproveitamento.

Sugerimos, durante a discussão, que a educação ambiental não seja uma prática diária no contexto cotidiano somente dos alunos e funcionários do hotel-escola, mas que seja também um exercício contínuo para todas as pessoas que passam pelo hotel-escola, abrangendo todos os níveis.

A maneira como essa abordagem pode ser feita deve atuar como um diferencial dos serviços do hotel-escola, como por exemplo: ao montar um buffet é comum que o mesmo seja composto de frutas exóticas ou raridades, como uma sugestão de fruta fora da época, tornando este um dos diferenciais do local. Durante a nossa fala, reforçamos que o hotel, ao adotar essa atitude (inserir no buffet uma fruta que não seja da época) gera um dano ao meio ambiente e, conseqüentemente às pessoas, uma vez que essa fruta precisa de um teor elevado de agrotóxicos e de adubos para sobreviver, já que a época do ano e o clima não estão favoráveis para a sua produção. Isso acarreta em prejuízo para a pessoa que está aplicando o agrotóxico e para os vizinhos da roça de produção da fruta, pois a chuva vai contaminar o leito do rio que por ali passa, espalhando "prejuízo" para diversas pessoas, tanto no que diz respeito àquelas que trabalham, quanto àquelas que desfrutam das terras vizinhas ou que consomem. 
Para amenizar essa situação, o hotel-escola pode repensar a sua conduta diante do próprio hóspede, de forma que o buffet seja composto de uma variedade reduzida de frutas temporãs, e composto em sua maior parte de frutas sazonais, de maneira que estas últimas tenham seu consumo incentivado através de placas educativas no próprio buffet.

O cuidado para que não denigra o próprio serviço de buffet, de daria de forma a ressaltar as qualidades das frutas que são da época, zelando pelos cuidados e incentivando o seu consumo. O diferencial do hotel-escola se pautaria na qualidade de vida do consumo dos alimentos, visando atender às premissas da educação ambiental. Essa seria uma iniciativa interessante para buscar atingir "o topo" da freqüência do Grande-Hotel SENAC, propiciando uma "corrente", evolvendo todos os níveis de pessoas que passam pelo hotel-escola, com diversas ações deste porte.

Os participantes ficaram muito motivados, mas disseram que essa deveria ser uma ação conjunta, envolvendo alunos de todos os níveis de ensino, desde o técnico profissionalizante até a pós-graduação, funcionários, estagiários, gerentes e colaboradores. Contudo, um treinamento como este não chega nunca no topo da pirâmide e nem aos níveis intermediários, o que acaba enfraquecendo qualquer ação.

Os professores devem estar cada vez mais preparados para reelaborar às informações que recebem - dentre elas, as ambientais - para poderem transmitir e decodificar para os alunos a expressão dos significados em torno do meio ambiente e da ecologia nas suas múltiplas determinações e intersecções (TRISTÃO, 2004).

\subsubsection{Educação Ambiental: perspectiva de racionamento ou dimensionamento}

Buscamos um aprofundamento na reflexão e no debate de alguns temas que já haviam surgido em etapas anteriores. O primeiro tema debatido foi o dimensionamento de produção culinária ao número de hóspedes, ou de pessoas denominadas no próprio hotel como "passantes" (se configuram somente como pessoas que passam pelo hotel para fazer as suas refeições, e que estão na cidade a lazer ou a negócio).

Os "passantes” são pessoas que não estão incluídas no planejamento do número de refeições do hotel. Com isso, o hotel tem sempre que se preparar para atender a esse público, preparando uma quantidade maior de refeições, o que, muitas vezes, acarreta em sobras no setor de alimentação, gerando desperdícios. 
Há um empenho na reutilização desses alimentos, mas nem sempre é possível, uma vez que muitos deles passam horas expostos nos buffets, gerando alterações no sabor e na qualidade.

\subsubsection{Racionalidade no uso de embalagens: respeito ao meio ambiente}

Outro ponto discutido é a aquisição de matérias-primas armazenadas em embalagens que acarretam em danos ao meio ambiente, tais como isopor, papel filme, papelão, dentre outras.

Um dos participantes comentou que todas as receitas desenvolvidas na confeitaria do hotel são compostas de ingredientes criteriosamente dimensionados e pesados, uma vez que a própria situação de repassar aos alunos as informações exige a disciplina e a higiene dos professores. Assim sendo, para cada item da receita a ser pesado, utiliza-se um pedaço de papel filme, o que consome diversos rolos ao longo do mês.

A idéia que surgiu dos próprios professores foi a de implantação de minibandejas de plástico, laváveis e que pudessem ser reutilizadas.

Segundo LEME (2006), as práticas vividas pelo próprio docente, ou por seus colegas, traz à tona a socialização, uma vez que essas experiências/práticas representam um momento de reflexão, pois enquanto o professor relata a sua vivência, acaba por fazer uma análise da mesma, o que também acontece com os colegas.

Seria viável a adoção de novos hábitos e procedimentos dentro dos departamentos da cozinha, inserindo neste contexto novos procedimentos na gestão do processo, incorporando atitudes voltadas para novos valores.

\subsubsection{Valores da Educação Ambiental}

Um outro quesito ao qual foi dado cuidado especial foi a questão do relacionamento profissional dentro dos departamentos da cozinha, uma vez que os setores não são solidários entre si, gerando uma individualização de atuação dos profissionais da cozinha em relação aos alunos e estagiários.

A brigada de cozinha funciona em sintonia, sem gerar conflito, porque apesar dos setores terem seu funcionamento independentes, cada um dá continuidade ao trabalho iniciado pelo anterior,. Dessa forma, as tarefas são bastante definidas. Por 
exemplo: a legumeria prepara previamente os legumes quanto à limpeza, higienização e padronização dos cortes; e a cozinha quente faz a cocção do alimento. Embora os setores tenham tarefas interligadas, as atividades são estanques, não deixando margem de dúvida quanto às funções.

Percebemos que cada setor cuida do seu espaço, e deixa de desempenhar qualquer atividade além daquelas que comumente faz, mesmo que o setor vizinho necessite. Então, só há harmonia quando cada um cuida da sua função.

Um exemplo claro disto foi um caso citado em reuniões anteriores, em que o responsável pelo setor de açougue mencionou que muitas vezes o cozinheiro da cozinha quente precisa de uma carne vermelha para um prato à la carte ${ }^{28}$, e quando há sobras da carne utilizada, esta volta para a câmara fria. O cozinheiro a dispõe em qualquer local, misturando-a às carnes brancas, o que faz com que estas tenham de ser descartadas antecipadamente.

Uma outra preocupação apresentada pelo grupo que provocou um debate foi a questão da utilização sem critérios dos produtos químicos. Os professores e alunos das atividades práticas atribuem um farto uso de produtos químicos - tais como álcool, detergente, sabão em pó, sapólio - para a higienização de um departamento. Não há um controle do uso desses produtos.

A utilização de grande quantidade dos produtos de higiene é uma agressão ao meio natural, pois acarreta também no uso indiscriminado de água para posterior remoção do produto para que o alimento não tenha contato com o mesmo - o que poderia ser prejudicial à saúde e gerar um dano ainda maior.

\subsubsection{Novas posturas nas práticas profissionais}

O seguinte item de relevância é em relação à montagem da mise-en-place ${ }^{29}$, uma vez que todo alimento tem uma receita padronizada no que se refere ao peso dos ingredientes. Dessa forma, os alunos, ao montarem a mise-en-place de uma aula ou de

\footnotetext{
${ }^{28}$ Prato que consta no cardápio do restaurante e que é preparado "in minute", ou seja, na hora em que o cliente solicita. No Grande Hotel tal serviço é oferecido somente quando o cliente solicita, e isso acontece com freqüência.

${ }^{29}$ Procedimento usual antes do início do trabalho do cozinheiro, pois propicia conforto, organização e rapidez no desempenho das suas tarefas, sem fragmentá-las, uma vez que a mesma se configura como a arrumação de todos os elementos de uso naquele dia de trabalho. Assim, o profissional não precisará ficar interrompendo suas atividades a fim de ter os produtos em mãos. Em toda a aula prática é designado um aluno que fica responsável pela montagem e arrumação do setor, integrando todos os itens de uso do dia, sem que falte nenhum para o bom desenvolvimento da aula e das atividades.
} 
uma preparação culinária pesam todos os ingredientes em copos descartáveis, que depois vão para o lixo.

Quando nos referimos aos ingredientes pesados em copos descartáveis, vemos que esta é uma prática intensa, porque são inúmeras mise-en-places preparadas diariamente em todas as cozinhas do hotel-escola, incluindo os laboratórios.

Os professores participantes desse processo mudaram esse hábito no decorrer do nosso curso. Os copos descartáveis foram substituídos por forminhas de alumínio que após o uso, são lavadas, esterilizadas e reutilizadas. Tal prática reduz a quantidade de lixo produzido pela cozinha. Porém, os demais professores das atividades práticas e dos laboratórios ainda continuam com tal procedimento.

\subsubsection{Iniciativa de Educação Ambiental no SENAC}

Os participantes relataram durante os encontros, que o SENAC São Paulo (sede) distribuiu para todos os funcionários da rede SENAC do Estado de São Paulo uma caneca de louça, com o objetivo de educar os funcionários para uma mudança de hábito no uso de copo descartável, pois o uso deste é muito comum dentro das unidades do SENAC do Estado de São Paulo. Apesar disso os referidos copos não saíram de circulação, pois não houve nenhuma iniciativa complementar de educação ambiental.

A caneca trazia, além da logomarca do SENAC, a seguinte frase: "Reduzir o consumo de recursos naturais. Beba desta idéia!”.

Os participantes chegaram a mencionar que os funcionários não entendiam porque estavam ganhando aquelas canecas, e que a maioria deles entendeu que se tratava de um brinde e as levou para casa. Os funcionários que exercem cargos inferiores na estrutura hierárquica da instituição entenderam que a distribuição da caneca tinha sido um presente para os filhos.

Nota-se que é necessário o cuidado para que a reflexão, a construção e participação das pessoas resultem em um motivo de transformação. Caso contrário, corre-se o risco de se promover uma manipulação das mesmas, as quais, muitas vezes, não sabem o motivo de suas atitudes. Além disso, o conhecimento subsidia as tomadas de decisões, evitando equívocos (LEME, 2006).

Após este encontro tivemos uma conversa com a coordenação do curso, objetivando resgatar o assunto discutido em sala de aula, pois ficamos indignados com o 
fato do SENAC distribuir a caneca sem uma ação pedagógica, sem propor uma reflexão sobre tal iniciativa.

A coordenação nos informou que como resultado do nosso curso junto aos professores, a direção da Faculdade de Águas de São Pedro resolveu, além de encaminhar este curso para Campos do Jordão - uma vez que precisa haver semelhança da grade curricular e a mesma iria sofrer modificações com a inserção do tema ambiental - também oferecer um curso que contemplasse primeiramente todos da área gastronômica, e depois todos do hotel-escola.

\subsubsection{Aspecto geral da ISO 14.000}

A ISO - International Standardization for Organization é uma organização nãogovernamental sediada em Genebra, fundada em 23 de fevereiro de 1947, com o objetivo de ser o fórum internacional de normalização, e atua como entidade harmonizadora das diversas agências nacionais.

Noventa e cinco por cento da produção mundial estão representados na Isso, por mais de uma centena de países-membros, os quais são classificados em $\mathrm{P}$ (Participantes) e $\mathrm{O}$ (Observadores). A diferença fundamental entre ambos é o direito de votação que os membros participantes têm nos vários Comitês Técnicos, Subcomitês e Grupos de Trabalho.

Para exercer seus direitos, é exigido que os países estejam em dia com suas cotas anuais de participação e atuem de forma direta no processo de elaboração e aperfeiçoamento das normas.

À medida que aumentam as preocupações com a manutenção e a melhoria da qualidade do meio ambiente, bem como a proteção da saúde humana, organizações de todos os tamanhos vem crescentemente voltando suas atenções para os potenciais impactos de suas atividades, produtos e serviços. O desempenho ambiental de uma organização vem tendo importância cada vez maior para as partes interessadas, internas e externas. Alcançar um desempenho ambiental consistente requer comprometimento organizacional e uma abordagem sistemática ao aprimoramento contínuo.

O objetivo geral da ISO 14.000 é fornecer assistência para as organizações na implantação ou no aprimoramento de um Sistema de Gestão Ambiental (SGA). Ela é 
consistente com a meta de "Desenvolvimento Sustentável" e é compatível com diferentes estruturas culturais, sociais e organizacionais.

Um SGA oferece ordem e consistência para os esforços organizacionais no atendimento às preocupações ambientais através de alocação de recursos, definição de responsabilidades, avaliações correntes das práticas, procedimentos.

A norma ISO 14001 estabelece o sistema de gestão ambiental da organização de forma que:

1. Avalia as conseqüências ambientais das atividades, produtos e serviços da organização;

2. Atende a demanda da sociedade;

3. Define políticas e objetivos baseados em indicadores ambientais definidos pela organização, que podem retratar necessidades, desde a redução de emissões de poluentes até a utilização racional dos recursos naturais;

4. Implica na redução de custos, na prestação de serviços e em prevenção;

5. É aplicada às atividades com potencial de efeito no meio ambiente;

6. É aplicável à organização como um todo;

7. Fornece auxílio às organizações no processo de efetivamente iniciar, aprimorar e sustentar o Sistema de Gestão Ambiental. Tais sistemas são essenciais para a habilidade de uma organização em antecipar e atender às crescentes expectativas de desempenho ambiental, e para assegurar, de forma corrente, a conformidade com os requerimentos nacionais e/ou internacionais.

\subsubsection{Séries da ISO 14000}

As organizações podem considerar diferentes usos da série ISO 14.000:

1. Usando a ISO 14.000 - Diretrizes para Princípios, Sistemas e Técnicas de Suporte, ou parte dela, para iniciar e/ou aprimorar seu SGA. A ISO 14.000 não é destinada ao uso por entidades de registro;

2. Usando a ISO 14001 - Especificação do Sistema de Gestão Ambiental, para alcançar certificação por terceiros. A ISO 14.001 é destinada ao uso por entidades de registro; 
3. Usando a ISO 14.000 - Diretrizes, ou a ISO 14.001 - Especificações, para reconhecimento de segunda parte, entre contratados, o que pode ser apropriado para algumas relações comerciais;

4. Usando documentos ISO pertinentes.

A escolha dependerá de uma série de fatores, tais como:

1. Grau de maturidade da organização: se já existir um gerenciamento sistemático poderá ser facilitada a introdução de um gerenciamento ambiental sistemático;

2. Possíveis vantagens e desvantagens, influenciadas pela posição no mercado, reputação atual, relações externas;

3. Dimensão da organização.

A diretriz 14.000 pode ser usada por organizações de qualquer tamanho. Todavia, a importância das pequenas e médias empresas vem sendo amplamente reconhecida pelos governos e meios empresariais. A diretriz reconhece e acomoda as necessidades das pequenas e médias empresas.

A ISO 14.000 oferece diretrizes para o desenvolvimento e implementação de princípios e sistemas de gestão ambiental, bem como sua coordenação com outros sistemas gerenciais.

Tais diretrizes são aplicáveis a qualquer organização, independente do tamanho, tipo ou nível de maturidade, que esteja interessada em desenvolver, implementar e/ou aprimorar um sistema de gestão ambiental.

As diretrizes são destinadas ao uso interno como uma ferramenta gerencial voluntária, não sendo apropriada para uso por parte de entidades de certificação/registro de sistema de gestão ambiental, como uma norma de especificações.

\subsection{Avaliação da formação ambiental}

\subsubsection{Reformulação dos planos de ensino pelos professores ${ }^{30}$.}

Após a formação ambiental, os professores agregaram temas relacionados ao meio ambiente aos seus planos de ensino (ANEXO B), levando-se em consideração a produção de conhecimento que deve necessariamente contemplar as inter-relações do

\footnotetext{
${ }^{30}$ A nova grade curricular será reestruturada também na unidade de Campos do Jordão, onde será ministrado um curso semelhante a este para os professores daquela unidade, objetivando não somente a
} 
meio natural com o social, considerando-se os professores envolvidos no processo.

Neste encontro aproveitamos também para avaliar junto aos professores - através de uma conversa informal, mas com um roteiro pré-estabelecido (APÊNDICE G) - a possibilidade de um acompanhamento das atividades escolares por intermédio de um controle das questões ambientais dentro das atividades pedagógicas desenvolvidas pelos mesmos junto aos alunos.

\section{Legumeria:}

Anteriormente ao curso percebemos que os professores não tinham ação reflexiva quanto às questões voltadas para educação ambiental. Com isso, no setor de legumeria, acrescentou-se à importância da higienização de hortifruti e a educação ambiental no ambiente gastronômico.

O aproveitamento das aparas dos cortes também entrou na pauta da aula do desenvolvimento de cortes técnicos, bem como o uso moderado dos recursos naturais.

Outro quesito novo na programação foi a higiene na manipulação dos alimentos - este assunto era abordado na primeira semana de curso, denominado de ambientação dos alunos e desenvolvido por uma psicóloga e uma nutricionista. Os professores ficavam à margem desta semana, já que a higiene na manipulação dos alimentos era um título trabalhado apenas pelas profissionais acima mencionadas. Durante os encontros pudemos repensar esta questão e refletir sobre o comprometimento de todos os profissionais da área gastronômica, - em especial os professores, que têm a função de repassar conhecimento e se fazer exemplo no cotidiano pedagógico dos alunos.

$\mathrm{O}$ uso moderado de produtos químicos entrou na programação e no plano de ensino, bem como a separação adequada do lixo e a luta pela sua redução, buscando, com isso, um maior rendimento dos alimentos e conseqüentemente, um aumento da receita. Ainda assim foram mantidos os cortes com perfeição, padronização e segurança. Entraram na programação também a racionalização da energia elétrica e o desenvolvimento de um trabalho em equipe, de forma harmoniosa e com espírito empreendedor.

\section{Açougue:}

Nas aulas do setor de açougue a programação foi contemplada com os cuidados

sintonia de linguagem e a similitude de grade curricular, mas principalmente a inserção de práticas de educação ambiental no curso. 
operacionais do departamento quanto à higiene e manipulação de aves, visando os cuidados para a não proliferação da salmonela, proveniente da carne de frango.

Cuidados na elaboração do cardápio quanto ao abatimento desordenado de animais, no que diz respeito ao equilíbrio ao meio ambiente, também foi um tema debatido e agora presente em sala de aula.

Outro item presente na programação é o reaproveitamento de alimentos e redução de resíduos, organização na manipulação e armazenamento adequado dos alimentos que se destinam à cozinha central, de forma que as matérias-primas sejam devidamente etiquetadas, utilizando-se, como mencionado anteriormente, as datas mais antigas, e reutilizando aquelas que tenham condições favoráveis.

Outro quesito destacado e agregado ao programa de açougue foi quanto a compra de matéria-prima com embalagem descartável, uma vez que o docente responsável pelo setor exemplificou que a estocagem do peixe é feita em embalagens de papelão descartáveis. Como entendemos que essa medida é desnecessária, neste encontro solicitamos uma reunião com o comprador, que sugeriu uma conversa com os fornecedores, buscando assim envolvermos mais pessoas no processo, de forma que sensibilizássemos todos os envolvidos nos novos procedimentos.

A questão do lixo será outro quesito trabalhado pelos professores em sala de aula, também no setor de açougue. Visando a qualidade na manipulação dos alimentos este item é um ponto frágil neste setor em especial, uma vez que há uma tabela de tempo em que a carne pode permanecer fora da sua refrigeração adequada, durante a manipulação - quesito este que estava fora da pauta do curso, mas que resgatamos durante todos esses encontros, no compromisso com a saúde do cliente interno e externo.

O uso indiscriminado de produtos de limpeza tais como detergente, sabão, álcool, sabão em pó, foi outro item presente no novo plano de ensino do professor responsável pelo açougue.

\section{Garde-manger}

O setor de garde-manger, assim como os demais, também foi abordado pelo professor e nele inseridos diversos temas de educação ambiental, que serão minuciosamente trabalhados pelo professor, uma vez que este setor é o responsável pelo buffet frio e, assim, pode-se durante o curso, sensibilizar e atentar os alunos quanto ao uso racional e ao reaproveitamento dos alimentos presentes no buffet dos hóspedes. 
A primeira aula será dedicada ao meio ambiente em especial, visando à conexão da área gastronômica com a educação ambiental. O objetivo desta aula é estimular os alunos a exercerem atitudes que no cotidiano se perdem. Julgamos que neste momento, em que o aluno está na metade do programa do curso, seria o ideal, já que ele não teria o estímulo do início em desbravar o novo, nem o estímulo da finalização, buscando neste momento uma zona de conforto. O objetivo é resgatar atitudes e valores da educação ambiental que já foram vistos no início do curso, a fim de arraigar procedimentos adequados no futuro profissional.

O uso de produtos químicos é um item permanente em todas as etapas do curso e propostos para ser trabalhado por todos os setores, uma vez que percebemos que este item aparece na reformulação do plano de trabalho de todos os docentes.

A limpeza e higienização do setor de equipamentos, bem como a manipulação dos alimentos, são tópicos importantes neste setor, uma vez que este departamento lida com produtos perecíveis e principalmente produtos que nem sempre carecem de cocção, tornando, assim, o alimento mais vulnerável e exigindo cuidados redobrados.

O nosso encontro se estendeu e muito no ponto em que debatemos a modalidade de serviço de um restaurante quanto ao uso de buffet ou serviço à la carte, uma vez que este setor e o setor de cozinha quente trabalham também com esta modalidade de serviço.

Durante o debate abordou-se a viabilidade de trabalhar com o reaproveitamento dos alimentos e readaptação das sobras em um restaurante com montagem de buffet. Alguns professores não concordaram, uma vez que a vigilância sanitária define que o alimento depois de duas (02) horas exposto em buffet não deve ser reaproveitado, mesmo que seja resfriado ou aquecido - o que não acontece no SENAC.

Houve indagações sobre os custos, viabilidades, vantagens de mão-de-obra, apresentação dos pratos, variações de cocção empregadas nos alimentos, desperdício, dentre outros, e como é comum acontecer, alguns professores são favoráveis ao uso da modalidade de buffet, enquanto outros são adeptos da modalidade de cardápio à la carte.

Outro assunto que deverá ser trabalhado com os alunos neste estágio do curso diz respeito ao reaproveitamento de alimentos, ao trabalho com produtos orgânicos e a reflexão junto aos alunos no que se refere à inclusão social dos munícipes dentro do hotel-escola, uma vez que este exerce um destaque no município de Águas de São Pedro, cuja população fica à parte dos eventos desenvolvidos dentro do hotel.

Um último item peculiar a este setor e que durante a reformulação mereceu 
atenção por parte do professor é quanto ao preparo de molhos. Os molhos reduzidos são aqueles que se caracterizam em tornar-se extrato, como é o caso, por exemplo, do tomate, que se torna massa de tomate. O curso aborda essas questões e desenvolve a prática dessas preparações culinárias, formando o aluno na totalidade, embora muitas vezes, dependendo do local em que atue, nem sempre empregará tais conhecimentos.

Este tipo de preparo demanda muito tempo de cocção, exigindo que permaneça no fogo por até três (03) dias contínuos de cocção. Assim, destaca-se a viabilidade desse preparo considerando-se o tempo de gás, energia elétrica e mão-de-obra, desprendida para tal preparo.

Contudo, o professor relatou durante a apresentação da reformulação do seu plano de ensino neste departamento da cozinha, que tais condições no preparo do molho serão ensinadas aos alunos, mas agora com outra visão, pois o professor planejou, a partir do curso ministrado por nós, refletir sobre as viabilidades, prós e contras referentes à execução do mesmo, no que tange não somente aos custos, mas também ao tempo e, principalmente, ao uso de materiais renováveis.

O setor de garde-manger é lida muito com produtos perecíveis no que diz respeito aos produtos de charcutaria, queijos, preparações com vinhos, gelatinas salgadas, muitos cremes e maioneses. Dessa forma, o armazenamento e o recebimento destas mercadorias tem que ser trabalhados visando qualidade e apresentação; este item não era trabalhado anteriormente ao desenvolvimento do workshop.

\section{Confeitaria}

O próximo setor discutido foi o de confeitaria, que engloba padaria e confecções de massas em geral, salgadas e doces.

O meio ambiente no setor de confeitaria é um quesito que foi agregado para ser trabalhado junto aos alunos. O produto orgânico é uma alternativa de alimentação saudável, de qualidade, porém pouco conhecido para os diversos professores que trabalharam conosco nos encontros. Assim, sugeriram uma visita técnica em restaurantes que já tenha agregado ao seu cardápio os produtos orgânicos, além de palestras e práticas de utilização do produto.

Conversamos com a coordenação do curso que aprovou tais visitas técnicas nos restaurantes e cozinhas acima mencionados, onde os professores terão acesso às informações sobre utilização do produto, bem como sobre suas vantagens e desvantagens, para que possam repassá-las aos alunos em formação profissional. 
O desperdício foi um item agregado ao planejamento do setor de confeitaria, uma vez que há muita sobra de massa, cremes e coberturas, e as mesmas são de fácil deteriorização.

Conforme mencionado anteriormente, o setor de confeitaria é o que utiliza o maior número de copos descartáveis, a fim de medir os ingredientes.

Além de utilizar os copos descartáveis, este setor faz uso também de plástico (papel filme) para pesagem em balança, objetivando atender às orientações expressas nas receitas, gerando, com isso, o uso de descartáveis em abundância.

Essa será uma prática trabalhada com ênfase pelo professor, antes da entrada dos alunos no setor de confeitaria, a fim de abolir tais procedimentos.

Um novo item presente na reformulação do plano de ensino do professor de confeitaria é o trabalho com receitas alternativas, objetivando o reaproveitamento dos alimentos de forma que os mesmos não sejam desprezados (indo para o lixo).

$\mathrm{O}$ reaproveitamento desses alimentos com qualidade e tempo útil para serem consumidos será possível se houver uma atenção por parte dos funcionários e, principalmente, dos alunos.

As sobras dos doces não devem ficar por muito tempo estocadas na câmara fria, para somente depois de dias serem reaproveitados ou encaminhados para consumo, pois, segundo o professor, os doces que sobram no buffet ${ }^{31}$ nem sempre são aproveitados ou reutilizados num curto período de tempo.

Outra questão que deverá, a partir de agora, ser abordada pelo professor é a degradação do meio ambiente e a sua poluição, uma vez que no desenvolvimento da aula de panificação com a produção de diversos tipos de pães e massas, o professor terá uma abertura para vincular o conteúdo.

\section{$\underline{\text { Cozinha Quente }}$}

Esta é a última etapa do curso, e nesta fase o professor introduziu no seu programa o tema meio ambiente com inserção na produção culinária, e a partir desse tema, o professor planejou resgatar os temas de educação ambiental abordados anteriormente à essa etapa do curso.

O quesito higiene alimentar, ambiental e pessoal na atual fase do curso é fundamental, uma vez que os profissionais estão quase prontos para atuar no mercado

\footnotetext{
${ }^{31}$ No jantar é servido um buffet de doces com grande variedade.
} 
de trabalho, devendo, contudo, resgatar conceitos e valores repassados ao longo do curso, buscando a garantia da qualidade de vida dos clientes, que deverão desfrutar dos serviços desses futuros profissionais do universo gastronômico.

Nesta última etapa do curso o professor espera que o aluno já consiga evitar o desperdício de alimentos e o seu reaproveitamento, vinculado à qualidade.

Nesta fase o aluno é disposto ao preparo de pratos buscando agilidade, padronização, coerência, flexibilidade e criatividade frente às diversas situações do mercado de trabalho e às diferentes condições dos estabelecimentos comerciais.

O objetivo do professor não é somente repassar aos alunos conceitos voltados para os custos - como era exclusivamente abordado antes do nosso curso de formadores ambientais - mas também fazê-los refletir sobre questões voltadas para o uso racional, degradação ambiental, sustentabilidade de matéria-prima e gerações futuras.

Formar indivíduos para atuar no mercado de trabalho é importante, mas é imprescindível atentar para a formação de indivíduos autônomos capazes de transformar a realidade (LEME, 2006).

Outra questão inserida no plano de ensino do professor é a de levar os alunos a refletirem sobre a futura atuação dos mesmos no mercado de trabalho.

Alguns alunos saem do curso e atuam imediatamente em cargos de chefia dentro de uma cozinha, principalmente quando o estabelecimento comercial é de pequeno ou até mesmo de médio porte. Muitas vezes esses profissionais acumulam a função de responsáveis pelo departamento de alimentos e bebidas. A busca pela redução de gastos operacionais facilita a sustentabilidade do comércio em um mercado tão competitivo, podendo manter as pessoas do estabelecimento empregadas, que podem, em alguns lugares, até mesmo terem um plano de carreira.

Assim, o item que passará a ser trabalhado em sala de aula pelo professor referese à discussão e reflexão, conforme mencionamos anteriormente, entre buffet e à la carte. O professor tem o objetivo de levar os alunos a pensarem sobre suas vantagens e desvantagens desses serviços, pois é comum que o dono do estabelecimento onde irá atuar não tenha formação específica para atuar nessa área - o que exige que o futuro profissional formado pelo SENAC ajude-o a planejar e definir a estrutura de funcionamento do restaurante.

O professor deste departamento agregou informações tais como: cálculo de custos, viabilidades, desperdício, praticidade, recursos físicos, recursos humanos - todos itens de grande relevância na elaboração do cardápio de um restaurante ou hotel, seja 
este de pequeno, médio ou grande porte.

É preciso despertar no aluno a necessidade de estar sempre pesquisando sobre as tendências atuais, visando os princípios discutidos nos encontros que permeiam a educação ambiental.

Cada professor reformulou individualmente o seu programa de curso e apresentou em sala de aula para todos os professores presentes que fizeram parte do workshop, que teve também, naquele momento, a presença da coordenação.

Ficamos animados com a agilidade da efetivação da validade do programa desenvolvido por nós durante as nossas pesquisas, e a inserção do meio ambiente e da educação ambiental nos programas do curso de gastronomia. O próprio diretor, no início das nossas pesquisas, aprovou o nosso projeto de intervenção e apoiou tal medida (o mesmo foi recentemente transferido para o Grande Hotel de Campos do Jordão).

Quando a coordenação do Grande-Hotel fez menção de tal alteração do programa, o mesmo prontamente a aprovou, uma vez que já conhecia o projeto e os objetivos, apoiando-nos no desenvolvimento de um programa semelhante ao que foi desenvolvido na unidade de Águas de São Pedro, que deverá se efetivar já para o ano de 2007.

Em relação ao programa efetuado na unidade de Águas de São Pedro, há um projeto em andamento para o desenvolvimento de um programa também pautado nas questões ambientais e que permeiam todos os níveis de ensino, abrangendo todos os cursos.

A nossa intenção neste trabalho foi despertar um interesse abrangente, que não se restringisse somente ao curso em que estávamos trabalhando, que englobasse a busca de bases de conhecimento para a educação ambiental a partir da sua abrangência e das interfaces com vários setores do hotel-escola, de forma que os próprios funcionários compreendessem a relação da educação ambiental com a sua atuação profissional. Que eles se vissem não somente como cozinheiros, ajudantes, chefes de setores, mas principalmente como modelos de educadores.

Durante o desenvolvimento do curso houve também uma alteração do quadro gerencial das áreas operacionais do hotel-escola. Contudo, as pessoas que assumiram cargos estratégicos dentro do hotel, conversaram conosco, a fim de desenvolverem um programa semelhante que abranja todas as áreas operacionais do hotel, buscando uma sintonia com a parte didático-pedagógica. 
Dessa forma, todos os funcionários estarão engajados nas questões voltadas ao meio ambiente e valores pautados na educação ambiental, uma vez que atualmente a distância entre teoria e prática, do que se ensina em relação ao que é executado, compromete sensivelmente a qualidade dos cursos, conforme mencionado por alunos e professores.

\subsubsection{Avaliação do curso pelos professores}

Ao final do curso elaboramos um questionário (APÊNDICE H) para ser respondido pelos professores, a fim de sabermos como eles avaliaram toda a reformulação e alteração do programa, com a inserção do meio ambiente na grade curricular do curso, bem como o curso ministrado por nós.

Segundo MARTINS citado por TRISTÃO (2004), as competências relativas ao envolvimento dos atores relevantes para alterar, requalificar, recriar novas orientações de desenvolvimento, têm o objetivo de chegar a trajetórias de desenvolvimento socialmente desejáveis e, simultaneamente, tecnicamente sustentável.

$\mathrm{Na}$ primeira questão indagamos sobre a relevância do curso e sobre o entendimento de meio ambiente em relação à profissão dos mesmos. Alguns afirmaram que não tinham conhecimento sobre questões pertinentes ao meio ambiente e que através do curso puderam ter maior contato com o tema, de forma que pudessem introduzi-lo como tema transversal em suas aulas.

Ainda referente à primeira questão, alguns alegaram que tinham uma filosofia de vida diferente, e que o meio ambiente estava bem longe do seu cotidiano. Afirmaram que através dos encontros, puderam reformular tanto a sua vida pessoal como o conteúdo de suas aulas.

Alguns afirmam que sua visão de meio ambiente, anterior ao curso, estava restrita ao verde, à vegetação; e após os debates puderam refletir a respeito, e verificaram que o meio ambiente é muito mais amplo e vai muito além da vegetação, pois está em todos os setores e em todos os ambientes, gerando uma interdependência entre ser humano e natureza, e vice-versa.

Algumas escolas passam uma concepção para o aluno do ser humano separado do meio ambiente, embora este seja parte implícita do mundo natural, conectada à sua dinâmica e funcionamento. 
Entretanto há escolas que já têm a preocupação do desenvolvimento de conteúdos vinculados às práticas pedagógicas calcadas na transmissão dos conhecimentos voltados para a educação ambiental, mas estes conhecimentos são trabalhados de forma tradicional, sem proposta de transformação social, nem tampouco individual. Na verdade as práticas pedagógicas precisariam estar baseadas em vivências que sensibilizassem os indivíduos para uma mudança de atitude individual, através de metodologias que estimulassem iniciativas das pessoas para mudanças de hábitos e valores, acreditando que desta forma poderia haver uma transformação na sociedade.

As práticas pedagógicas deveriam estimular a participação, o desenvolvimento de habilidades e valores individuais e coletivos, bem como propiciar a participação e, conseqüentemente, a transformação social.

Segundo TRISTÃO (2004), o conhecimento, a construção desse conhecimento e a transformação do processo de construção e reconstrução de conceitos e de uma articulação entre o ser humano, natureza e sociedade se organizam a partir das próprias interações.

$\mathrm{Na}$ segunda questão indagamos sobre o vínculo que eles consideram ter na relação do tema ambiental com a área gastronômica, bem como os seus aspectos.

Nos surpreendemos ao verificar que houve uma diversidade grande de respostas, de forma a enriquecer a nossa coleta de dados. Também pudemos verificar que os encontros tiveram grande relevância na formação ambiental de cada um deles.

É cada vez maior a falta de profissionais que tenham o saber ambiental em várias temáticas das ciências naturais e sociais e estes conhecimentos não se incorporam aos conteúdos curriculares de programas educativos. Segundo REIGOTA (2001), mesmo com a oferta crescente de pós-graduação em diversos temas ambientais, podemos questionar o grau de interdisciplinaridade e da ambientalização de seus conteúdos.

Um dos professores considera total a ligação do meio ambiente com a sua profissão, após o treinamento; uma vez que o mesmo levou-o a refletir que a gastronomia tem ligação direta com o meio natural, pois vários temas foram discutidos durante o desenvolvimento do programa, temas estes que estão diretamente inseridos na área gastronômica, sobre os quais eles não haviam refletido anteriormente.

Outros dizem sentir um grande incômodo ao fator "desperdício", uma vez que este item é de grande relevância na realidade que vive ali, dentro do hotel-escola frente s questões de educação ambiental. 
Segundo LEME (2006), a educação transforma e promove mudanças, mas serve também como instrumento da sociedade para manter, reproduzir e legitimar a estrutura econômica e política, bem como o autoritarismo, a injustiça, a intolerância, a desigualdade de classe, gênero e raça - que é exatamente o inverso do proposto da educação ambiental. Portanto precisamos estar atentos a estas ciladas.

Um outro professor atribui que o curso pôde contribuir não somente no que se refere às questões voltadas para a matéria-prima usada na gastronomia proveniente do meio natural, mas também referente à procura constante da higiene na manipulação dos alimentos, à inserção social e à cidadania, que favorecem a busca do repensar valores e conseqüentemente, mudanças de atitudes, tanto no campo profissional como pessoal.

Outro professor considera que o tema ambiental tenha uma ligação direta com a gastronomia, uma vez que está interligado por agentes diretos e indiretos, em fatos concretos, como a matéria-prima, o lixo, o desperdício; e fatores indiretos, como a saúde do consumidor, a higiene, a ética.

$\mathrm{Na}$ terceira questão procuramos investigar sobre a contribuição do curso, em relação à inserção do tema em questão na grade curricular do curso.

Todos os professores alegaram que já havia uma atenção voltada para a questão ambiental no curso, mas que a mesma - como já detectamos anteriormente - não era praticada de forma efetiva junto a todos os alunos, e quando praticada não havia um registro no plano de ensino dos professores, ou qualquer outro documento de forma que tornasse legal e formal essa prática pedagógica, não criando um compromisso dos mesmos para com o tema em sala de aula.

Eles complementaram dizendo que o curso favoreceu a organização da inserção do tema a todos os grupos de alunos, gerando um comprometimento por parte dos docentes quanto ao desenvolvimento do tema em sala de aula, mas também com relação à pesquisa voltada para essa temática, de forma que todos (alunos, professores e coordenação) refletissem sobre o assunto.

Outro quesito que apareceu nas nossas pesquisas dentro deste item foi quanto à responsabilidade que o mesmo gerou referente ao bem estar do próximo enquanto "ser humano", não somente no que diz respeito à saúde de forma geral, mas também a outros valores, tais como: solidariedade, respeito, ética e inserção social. O curso propiciou a cada um dele uma revisão de atitudes, não somente quanto à vida profissional, mas também à pessoal. 
O curso, segundo um professor, proporcionou clareza do assunto em questão, fortalecendo o compromisso que todos os profissionais têm que ter em relação à educação ambiental e ao meio ambiente.

Os docentes trabalharam na grade curricular de forma autônoma, para que pudessem desenvolver uma proposta que atendesse a realidade pedagógica de cada professor e dos seus alunos, bem como as disciplinas ministradas por cada um deles. Eles assumiram o compromisso de aplicar junto aos alunos uma grade curricular permeada pela educação ambiental, assim como também manifestaram satisfação por terem reconstruído o seu plano de trabalho, com a nossa ajuda, pautado nas questões desenvolvidas durante toda a reflexão gerada nos encontros. Houve um comprometimento e um engajamento por parte de cada um referente à nova proposta de ensino frente às questões ambientais.

Segundo SEGURA (2001) citado por LEME (2006), a participação é o elemento chave para criar condições para que alunos e professores sintam-se motivados a trabalhar.

Para JACOBI (1998), a participação é um instrumento de cidadania, uma vez que mobiliza e sensibiliza as pessoas para que transformem as diversas formas de participação em defesa da qualidade de vida. Isso nada mais é do que uma educação para a cidadania, ou uma educação ambiental com um caráter transformativo.

Os objetivos de se promover a participação são inúmeros, como: desenvolvimento da autopromoção, realização da cidadania, exercício e consolidação da democracia, controle de poder, negociação, etc. (DEMO, 2001).

Percebemos que o envolvimento dos professores, assim como a participação, favorece a co-responsabilidade, levando-os a incorporarem uma nova conduta pessoal e profissional, imbuída de novos valores pautados no respeito, humildade, confiança, solidariedade, compreensão e cooperação.

Outros dois professores consideram que durante o curso faltaram visitas técnicas com o objetivo de conhecer novos lugares, de forma que enriquecesse a atuação de cada um deles. Conforme mencionado anteriormente, em reunião com a coordenação e professores, estamos articulando visitas, palestras, contato com novos fornecedores, dentre outros.

A quarta questão abordada foi em relação à integração do meio ambiente à disciplina ministrada, especificamente por cada professor. As respostas mais uma vez nos surpreenderam, pois quando fizemos a sondagem inicial para montarmos o 
programa do workshop, baseado na realidade, nas necessidades e nas dificuldades dos professores, essa correlação era uma questão remota e sem muita conexão com os conteúdos abordados em sala de aula.

Assim, foi unânime a correlação da abordagem ambiental ao tema desenvolvido em cada disciplina e por cada professor, inclusive um deles mencionou que esse tema já deveria ter feito parte da sua prática em sala de aula há muito tempo, uma vez que as pessoas devem ter consciência de que a educação ambiental envolve tudo e todos, e de que depende somente de nós contribuir para a melhoria e preservação do meio natural, adotando atitudes que façam diferença no dia-a-dia, para nós mesmos e para o próximo.

Um outro professor disse que não era possível num primeiro momento fazer uma transformação geral do universo, nem tampouco do hotel-escola todo, mas que era possível buscar essa transformação aos poucos dentro do âmbito de atuação de cada um; e que a inserção na prática pedagógica diária frente ao meio ambiente ou temas da educação ambiental, leva os alunos a uma sensibilização, reflexão e novos hábitos no compromisso de um mundo melhor. Cada um fazendo a sua pequena parte, já é um começo.

Segundo TRISTÃO (2004), o processo da busca da inserção da educação ambiental no processo pedagógico se dá através do aprender a aprender, dialógico, e pode produzir outros sentidos, por ser mais flexível, vivencial, menos estruturada.

A busca da aprendizagem deve se basear não somente na sua prática docente através da reflexão sobre a sua prática pedagógica, mas também na construção constante do conhecimento e a sua desconstrução, e novamente a sua reconstrução de forma dialética na busca do ato de aprender, desenvolvendo, assim, a capacidade de aprender, de produzir e de participar.

A forma de compreender o mundo está munida de pensamentos muito consolidados. A busca do treinamento que fizemos e a introdução da reflexão no cotidiano prático-operacional dos professores teve o objetivo de provocar enfatizar novas idéias relativas à educação ambiental e questões pertinentes à esse tema, para que os professores fossem além de informações do senso comum, para os despertarem para um pensamento complexo sobre a educação ambiental.

Os professores durante esta questão deixaram claro que estavam conscientes de que, de forma direta ou indireta, tudo está relacionado ao meio ambiente.

A próxima questão que abordamos foi quanto à profissão na área de serviços, em especial à área gastronômica, estar inserida no contexto de meio ambiente. Solicitamos 
aos professores que explicassem esta afirmação a partir dos encontros realizados durante o workshop.

Todos os professores concordaram que a gastronomia depende diretamente do meio ambiente em diversos itens, não somente no que se refere à matéria-prima, que é um quesito direto, mas também à questões indiretas. Eles têm consciência, atualmente, que muitos itens além da gastronomia estão envolvidos com o meio ambiente, pois os encontros, segundo os professores, despertaram uma reflexão referente a esse assunto, além de uma busca contínua de todos os itens do cotidiano, não só da área de atuação deles, mas do dia-a-dia do grupo, na vida pessoal de cada um.

A reflexão propicia o pensamento filosófico, uma vez que possibilita, neste caso em específico, a relação entre ser humano e natureza, cultura e natureza, além de uma reflexão sobre a nossa própria posição no mundo.

Segundo TRISTÃO (2004) a ciência em si é complexa, aporta para a interseção de várias áreas do conhecimento e da ação e interesses humanos para a formação interdisciplinar e transdisciplinar.

Foi proposto ao grupo de professores, a partir da realização do workshop, a reformulação dos planos de ensino, feita por eles próprios. Objetivando a reformulação desse documento, buscamos uma inserção do tema ambiental, visando novas atitudes referentes a esse assunto.

Neste momento um dos professores se voltou para a questão do consumismo, fazendo uma análise do cotidiano, da força da mídia, da mudança de condutas frente ao colega de trabalho, com relação ao trabalho "verdadeiro" de equipe enquanto o desempenho de um "time", em que todos os integrantes rumam para objetivo comum.

Eles exemplificaram o cuidado em apagar as luzes quando a sala de aula, ou o laboratório, dispõe de claridade, ou quando se ausentam do ambiente; em servir o próximo, mesmo que isto custe um trabalho a mais para a equipe do departamento que tem interligação.

Outros professores perceberam a responsabilidade em formar futuros profissionais, pois exercem as funções de educadores, e de formadores de futuros profissionais, que atuarão no mercado de trabalho segundo sua formação, como aprendizes do oficio de cozinheiro, e muitas vezes exercerão a função de chefes, que comandam equipes. E é importante que esses profissionais atuem de forma positiva e consciente frente aos diversos campos do saber, em especial frente às questões de meio ambiente e de educação ambiental. 
Dentro da modalidade de ensino aprendizagem especificamente deste curso, Tristão (2004) menciona o resultado do trabalho da Comissão Internacional sobre Educação para o Século XXI, citando a busca na formação profissional do aprender a conhecer, aprender a fazer, aprender a viver junto e aprender a ser. Os itens por ela citados se encaixam com o comprometimento da formação de futuros atuantes no mercado de trabalho, de maneira que estes busquem uma atuação profissional pautada no respeito às diferenças, e de modo que o conhecimento atue como articulador de atitudes e de valores não conformistas, além de práticas estimuladoras de solidariedade, auto-estima, justiça e democracia.

Alguns professores mencionaram que levarão o aprendizado dos encontros para a vida toda, não se restringindo somente às questões profissionais, e que poderão influenciar na educação dos filhos e nas comunidades de bairro onde cada um mora. Pudemos sentir uma empolgação grande por parte deles no que tange à "bandeira" voltada para as questões de meio ambiente e a adesão de novas atitudes frente à educação ambiental.

Após a realização do workshop, solicitamos aos professores para que respondessem se encontraram alguma dificuldade para a inserção do tema nas práticas de ensino, e caso tivessem encontrado, quais seriam essas dificuldades. Pudemos constatar que os professores envolvidos no processo são muito conscientes de que o papel de militante frente a questões ambientais é um trabalho difícil, processual e lento, mas que segundo eles vale a pena, uma vez que estarão pensando nas gerações futuras, e na própria sobrevivência.

Uma questão ressaltada pelo grupo é de que embora todos os funcionários do hotel-escola, ainda que não atuem em sala de aula, exercem a função direta ou indiretamente de educadores, pois de acordo com os mesmos, eles interagem diretamente com os alunos e estagiários. Dessa forma, é preciso que todos tenham o compromisso de serem e atuarem o tempo todo como educadores, pois lidam diretamente com aprendizes e contribuem para formação profissional destes.

É papel dos educadores, juntamente com a escola, evitar as miopias paradigmáticas e reconhecer nessa transição de conscientização do papel de todos os professores o início da incerteza e a oportunidade de desenvolver uma educação para um futuro sustentável (TRISTÂO, 2004).

Seria bastante interessante se esse treinamento que foi dado sobre meio ambiente e educação ambiental pudesse abranger também todos os funcionários, para que todos 
caminhassem na mesma vertente e em um único sentido com relação aos novos valores e às práticas diárias junto aos alunos.

Para finalizar a nossa pesquisa, solicitamos aos professores que nos dessem sugestões quanto ao tema em questão. Sugiram muitas idéias quanto à organização de treinamentos e palestras que envolvessem todos os funcionários do hotel-escola, abrangendo todos os níveis de atuação, pois todos atuam de forma direta ou indireta na formação profissional do aluno e, portanto, atuam como educadores, desde as funções mais simples até os gerentes, nas diversas áreas do Grande Hotel SENAC.

Uma outra sugestão foi a organização de visitas técnicas na busca de novos conhecimentos e integração com órgãos diversos ligados ao assunto, de forma que haja uma troca de informações, resultando em aspectos positivos para todos os envolvidos. Sugeriram a busca de palestrantes que trouxessem estudos de caso, visando solucionar problemas peculiares que os próprios profissionais envolvidos com o processo dentro da formação profissional não conseguem vislumbrar, soluções ou alternativas de novas buscas.

\subsubsection{Avaliação dos efeitos do curso com os alunos}

Para coleta de resultados junto aos alunos, aplicamos um questionário (Apêndice I) através do qual pudemos avaliar duas turmas que estavam no término do curso. Os dois grupos eleitos foram aqueles que estiveram cursando no SENAC de Águas de São Pedro, durante o período da nossa pesquisa. Assim, tivemos uma amostra real dos resultados, uma vez que as mesmas pessoas foram pesquisadas no início da nossa intervenção, e depois, em um segundo momento no final.

O objetivo da pesquisa foi verificar se os professores haviam iniciado a aplicabilidade dos novos planos de ensino no curso, e avaliar os resultados da mesma nas questões pertinentes à educação ambiental.

A primeira questão abordada refere-se ao entendimento dos alunos em relação ao meio ambiente. Pudemos perceber pelas respostas dos alunos uma clareza e coerência com relação a todos os questionários, ficando evidente, que os professores têm trabalhado o tema em todas as turmas, conforme havíamos proposto durante o curso.

Percebemos nas respostas dadas pelos alunos que a natureza não está mais a serviço do ser humano, como havia sido mencionado anteriormente. Esse conceito 
mudou de forma que a maioria respondeu que meio ambiente são todos os recursos naturais do planeta, recursos que são necessários a todos os seres humanos para a sua sobrevivência.

Outro grupo respondeu que percebe o meio ambiente como um "todo" na nossa vida, ligando-o a todas as formas de vida, de forma que cada um faz parte do meio ambiente.

Em respostas anteriores apareceu com maior freqüência o meio ambiente a serviço do ser humano. Há sensivelmente uma mudança de visão e interpretação do meio ambiente com relação ao ser humano, uma vez que posteriormente surgiram que afirmam que todos os seres vivos fazem parte do nosso planeta e têm que se relacionar harmoniosamente.

Reforçando a questão acima, outro grupo de alunos respondeu que meio ambiente é tudo o que envolve o nosso viver e estar; seria onde vivemos, trabalhamos e estamos diariamente.

A afirmação do grupo acima nos evidencia claramente que a preocupação com o meio ambiente está inserida no dia-a-dia de todos, não mais desintegrando o ser humano do meio, seja esse meio uma cachoeira, ou até mesmo o escritório (segundo exemplo dos próprios alunos).

Um único aluno manifestou a preocupação com as gerações futuras, através do respeito ao meio ambiente, a fim de vivermos (ser humano e recursos renováveis) em harmonia.

Também houve um único aluno que interpretou o meio ambiente como o local onde vivemos e de cujos recursos dependemos para termos saúde, conforto e bem-estar. $\mathrm{Na}$ resposta desse aluno percebemos que há uma significativa mudança de entendimento frente às concepções de meio ambiente, trabalhadas em sala de aula pelos professores.

A questão de uso racional dos recursos naturais é outro item que esta sendo trabalhado em sala de aula, uma vez que o aluno fez menção a esse assunto em sua resposta.

$\mathrm{Na}$ segunda pergunta buscamos investigar a concepção dos alunos sobre educação ambiental.

Um deles respondeu que educação ambiental é tudo aquilo que pode interferir negativamente na natureza, prejudicando-a. Percebemos que esta resposta está intimamente ligada ao curso, uma vez que enfocamos o tempo todo a inter-relação das 
atitudes do ser humano frente à natureza e os seus reflexos - e neste caso especifico, as atitudes dos cozinheiros.

Mais uma vez fica evidente o quanto foi relevante a nossa intervenção, pois um grupo de alunos mencionou a importância das atitudes do dia-a-dia das pessoas, já que através das atitudes podemos dar exemplo de educação ambiental. O exemplo utilizado pelo grupo foi quanto ao encaminhamento do lixo, uma vez que o seu percurso não deve ser fragmentado, e sim deve haver segmento durante todo o seu processo. Como vimos anteriormente no curso, os professores mencionaram a falta de compromisso do encaminhamento e da separação do lixo, pois este é selecionado apenas por uma parte dos funcionários, mas tem como destino final apenas um recipiente.

Outro aluno mencionou no questionário que a educação ambiental está diretamente relacionada ao ser humano enquanto "respeito consigo mesmo nas suas atitudes", reportando-se a educação ambiental enquanto forma de mudança de atitude no que diz respeito à troca e à importância de cada um.

Os valores mencionados acima foram debatidos em todos os encontros e refletidos pelos professores. Percebemos que os conteúdos trabalhados com os professores em sala de aula estão sendo empregados no curso de cozinheiro.

Para a nossa satisfação pessoal, o próximo grupo de alunos respondeu diretamente que diariamente os professores, além de estarem orientando os alunos quanto as questões ambientais, têm mostrado atitudes que reforçam novos valores frente ao meio ambiente e às pessoas.

Alguns alunos responderam que entendem educação ambiental como uma forma de conservar as riquezas naturais, para que no futuro não se esgotem. $\mathrm{O}$ curso de cozinheiro orienta os alunos a fazerem uso racional desses recursos, ao uso consciente e ao respeito.

Um aluno respondeu que o seu entendimento com a educação ambiental é através de atitudes que respeitem o meio ambiente e tudo o que faz parte dele, para que o mesmo não seja prejudicado e nem tampouco o ser humano; entendeu também como sendo atitudes que agregamos durante o curso na formação deles e que os mesmos vão levar para a vida toda no que tange à atuação profisssional e pessoal.

A resposta de outro aluno foi em relação à conscientização sobre a proteção do meio ambiente para a proteção da nossa saúde, de nossas vidas e das gerações futuras. Ele define a educação ambiental como uma forma de conscientizar as pessoas quanto às novas atitudes em relação ao meio ambiente. 
$\mathrm{Na}$ terceira pergunta abordamos a questão ambiental enquanto ligação direta com a atividade de cozinheiro, e pedimos para que eles relacionassem quais seriam estas ligações. Todos responderam que há ligação direta da questão ambiental à profissão que escolheram, uma vez que a cozinha esta direta e indiretamente ligada ao meio ambiente.

Um grupo de alunos respondeu que a questão ambiental está ligada a tudo e à qualquer tipo de atividade.

O outro grupo de alunos acha que trabalha diretamente com produtos vindos do meio ambiente, de forma que a ligação do meio natural com a cozinha é intensa. Este grupo mencionou os produtos utilizados, os procedimentos em relação ao uso racional de produtos químicos e recursos naturais, além do cuidado com o meio ambiente na separação do lixo.

Um aluno respondeu que todos terão que ter consciência sobre as atitudes frente às questões ambientais, pois eles estarão atuando no mercado de trabalho.

Percebemos uma preocupação dos futuros profissionais nesta resposta, quanto a se atualizarem constantemente, uma vez que estão prestes a atuar enquanto profissionais no mercado de trabalho competitivo.

A resposta do outro grupo de alunos foi em relação à preocupação do lixo, que conforme vimos durante o curso, parece ser um problema dentro do hotel-escola. $\mathrm{O}$ resultado dessa ocorrência com o lixo se dá pelo fato de apenas alguns profissionais serem conscientes das questões com relação ao meio ambiente, enquanto outros não sabem o porquê da execução de tais tarefas.

Os produtos químicos utilizados para a higienização dos departamentos e utensílios da cozinha são componentes que requerem cuidado e preocupação - algo que antes da realização do curso, os profissionais não tinham, nem ao menos mencionavam em sala de aula. Este foi um item inserido no planejamento de cada professor, bem como será inserido na grade curricular do curso.

Outra sensibilização evidente que observamos depois da realização do workshop foi a correlação que há entre o meio ambiente e as pessoas de forma geral, seja no trabalho, no lazer ou no dia-a-dia.

Evidenciando a questão acima, um grupo de alunos respondeu que a questão ambiental está inserida na vida de todos, uma vez que ao sair de casa, no percurso do trabalho, as pessoas estão usufruindo o meio ambiente - algo que abrange todas profissões e todos os seres humanos. 
Uma nova informação foi adicionada à aula dos professores: a preocupação com o desperdício, uma vez que os alunos mencionaram esse tópico na pesquisa, referindose a alimentos, produtos químicos e sobras, e pautados em questões relativas à educação ambiental e meio ambiente, e ao armazenamento adequado da matéria prima utilizada na profissão.

Mencionaram também os cuidados no reaproveitamento de alimentos dos setores, além do prazo de reutilização desses alimentos, bem como a estocagem correta de materiais que poderão ser reutilizados. Mencionaram a importância de estarem atentos aos prazos, temperatura e métodos de cocção correspondentes a cada preparação - itens que, anteriormente ao curso, não eram trabalhados pelos professores na formação desses futuros profissionais.

$\mathrm{Na}$ questão seguinte indagamos sobre as disciplinas que compõem o curso de cozinheiro, pois queríamos saber se havia alguma delas que já estava trabalhando as questões ambientais, conforme planejamos durante o curso.

Somente duas pessoas de todo o grupo afirmaram que a questão ambiental ainda não estava sendo abordada, uma vez que os professores trabalham sutilmente este tópico, o que não é feito diretamente, embora esteja presente em todas as aulas. Eles mencionaram a questão do lixo - que ainda é fragmentada; e a questão do desperdício de água, e consideram que as informações ambientais são trabalhadas de forma limitada.

Os demais do grupo disseram que há uma preocupação explícita da parte dos professores em inserir a questão ambiental nas aulas, uma vez que questões como reciclagem, higienização, desperdício, encaminhamento e seletividade do lixo, aquisição de produtos e cuidados com os fornecedores, estão sempre presentes nas salas de aula como orientação ou como alerta dentro da formação profissional desses alunos.

Alguns alunos observaram que as informações sobre a questão ambiental dentro da formação do curso se apresentam de maneira contraditória, uma vez que, segundo eles, a questão ambiental é abordada em todas as aulas, evidenciando as preocupações dos professores com relação ao meio ambiente; entretanto, na prática, devido à agilidade do setor prático, esses cuidados com o meio ambiente ficam para um segundo plano.

Conforme mencionado por nós e pelos participantes durante toda a realização do workshop, a faculdade tem uma diretriz e as pessoas que atuam diretamente na atividade prática dos setores do hotel tem outra. No entanto, ambos os departamentos atuam diretamente na formação desses futuros profissionais. Pudemos observar que os alunos sentem esse distanciamento da escola para com os setores do hotel, e não há um 
consenso na conduta desses profissionais. Com isso, a formação profissional dos alunos que por ali passam fica comprometida, uma vez que cada profissional ruma para um lado.

Os alunos que atuam dentro desses setores não são somente do nível operacional, mas também de outros níveis de cursos de formação. Muitos deles atuarão futuramente na gestão de empresas de grande porte, uma vez que diversas redes internacionais de hotelaria absorvem estes profissionais formados pelo SENAC, para atuarem dentro e fora do Brasil.

Um outro item mencionado por um aluno foi a apresentação pessoal, pois os professores, segundo ele, cobram diariamente essa questão em todas as aulas. Foi mencionado também o uso correto de sanitários, principalmente para quem lida com alimentos, questões voltadas para o cuidado com a própria saúde, o aparo das unhas, cuidados com a dentição e com a apresentação pessoal, tais como banhos antes de entrar no setor de atuação profissional, limpeza dos uniformes, cabelo e barba (para os homens).

$\mathrm{Na}$ quinta questão indagamos sobre os assuntos ligados ao tema ambiental que foram incorporados nas disciplinas. Um grupo de alunos mencionou vários temas, como: reciclagem, higiene, desperdício, separação de lixo, uso moderado de água, uso sem necessidade de água quente, reaproveitamento, cuidados com acidente de trabalho, dentre outros.

Esse mesmo grupo disse também que ficou evidente o empenho dos professores com relação à conduta em esforçar-se em busca da conscientização por parte dos alunos no que tange os temas: meio ambiente e educação ambiental, tais como o relacionamento com pessoas, com colegas de trabalho, aquisição de materiais de produtos e fornecedores - questões essas que anteriormente não eram trabalhadas.

Um grupo de alunos disse que há professores que trabalham muito bem o conteúdo voltado para a questão ambiental, mas não de forma direta.

Disseram também que há atitudes de funcionários do hotel-escola que não ilustram questões trabalhadas em sala de aula com relação à educação ambiental, e que tais procedimentos não estimulam valores voltados para atitudes de solidariedade, companheirismo, humildade, de se fazer exemplo. "Diversos chefes de departamento não executam aquilo que é passado para nós em sala de aula".

Novamente aparecem questões trabalhadas por nós durante o desenvolvimento do curso, que não são praticadas nos setores do hotel, nem dentro da cozinha do mesmo. 
Apenas uma pessoa mencionou que os professores não incorporaram nenhum conteúdo ligado ao tema ambiental em aula.

Lamentavelmente, uma única pessoa ainda não acredita que um país sem cultura como o nosso possa mudar. Segundo ele, a sociedade cada vez mais ignora tal tema de grande relevância.

Segundo PELICIONI e PHILIPPI JR (2000) em LEME (2006), a educação nunca é neutra; ela reflete necessariamente a ideologia de quem trabalha com ela, podendo ser reprodutora ou questionadora da ideologia dominante.

Na última questão perguntamos se houve algum tema ligado ao meio ambiente de relevância que não foi abordado durante o curso. As respostas obtidas referem-se mais à importância do curso na carreira profissional dos alunos do que propriamente a possíveis temas não abordados. Acreditamos, com isso, que os temas ambientais que os alunos julgam importantes foram abordados de alguma forma.

Um grupo de alunos acredita que está preparado para enfrentar o mercado de trabalho, não somente no que se refere às técnicas relacionadas à gastronomia, mas também a assuntos correlatos dentre essas técnicas e o meio ambiente.

Outro grupo mencionou que os funcionários em geral deveriam ser preparados para a função de educador, principalmente de questões relativas ao meio ambiente.

Para outro aluno, o curso aborda constantemente questões relacionadas ao meio ambiente. Ele disse que irá para Bahia para atuar profissionalmente, e que irá levar as questões relativas ao meio ambiente para serem trabalhadas no seu futuro emprego.

Um grupo de alunos mencionou haver muito conflito entre informações transmitidas pelo monitores e pelos funcionários do hotel, como por exemplo: há uma orientação para que os alunos e funcionários lavem as embalagens para serem recicladas; entretanto na prática isso não é feito, uma vez que os setores práticos da cozinha acham perda de tempo, ou atribuem isso à correria ou ao comodismo.

Mais um grupo de alunos mencionou que os monitores têm consciência das questões voltadas para o meio ambiente, mas os funcionários do hotel não têm, agindo de forma contrária àquilo que foi ensinado em sala de aula.

É preciso fazer uma campanha também nos apartamentos dos alunos, pois é mencionado somente o posto de atividade prática e pedagógica, esquecendo de trabalhar junto aos alunos o desperdício nos banheiros e quartos, quanto à energia elétrica e água.

Alguns alunos fizeram menção àquilo que evidenciamos durante as nossas pesquisas quanto à informação fragmentada de assuntos relacionados ao meio ambiente. 
Um exemplo disso (mencionado pelos alunos) é o encaminhamento do lixo, já que no meio do processo de seleção para reciclagem ele se perde, porque, na maioria das vezes, o responsável pela atividade não tem informação.

Assim, entendemos durante todo o debate dos encontros com os professores, que o curso de formadores ambientais deve abranger todos os níveis hierárquicos do hotelescola.

Outro ponto mencionado pelos alunos e discutido em sala de aula, diz respeito ao reaproveitamento da água que é utilizada para lavar legumes ou verduras, e depois é descartada, quando poderia ser reutilizada para limpeza de banheiros, uma vez que a mesma é quase limpa.

Um novo item mencionado também pelo grupo de alunos e discutido em sala de aula, diz respeito à energia elétrica, que poderia ser substituída por energia solar.

Somente um aluno afirmou que no programa do curso deveriam ser agregados muitos outros temas que dizem respeito ao meio ambiente. Ressaltou também o desperdício de alimentos, pois muito é jogado no lixo, sem que haja um reaproveitamento.

Esse é outro item que foi debatido durante os nossos encontros, necessitando de um trabalho integrado de mudança de mentalidade e de valores dentro da equipe do Grande Hotel.

Assim, a educação ambiental nos possibilita abrir um estimulante espaço para repensar as práticas sociais - e em especial o papel dos professores enquanto mediadores e transmissores de informações, conhecimentos e experiências - favorecendo que os alunos tenham uma compreensão do meio ambiente global e local, da interdependência dos problemas e soluções, e da importância da responsabilidade de cada um para construir uma sociedade mais eqüitativa e ambientalmente sustentável (TRISTÃO, 2004). 


\section{CONSIDERAÇÕES FINAIS}

A intervenção desenvolvida por nós durante todo o processo, foi considerada um trabalho bem aceito pelo grupo, pois os professores demonstraram boa vontade e prédisposição em participar das atividades. Além disso, inseriram, entusiasmados, os conteúdos discutidos nos encontros em suas atividades pedagógicas, de forma que compartilhassem a reestruturação do plano de ensino, bem como sua dinâmica, dentro da sala de aula teórica e prática.

A questão ambiental era considerada um tema de grande relevância, apesar de pouco abordado, Relevante, primeiramente porque o que esses profissionais sabiam a respeito do assunto era superficial e restrito. Assim, compreendemos que os participantes passaram a perceber a necessidade de se ter uma visão global e crítica das questões ambientais, partindo do senso comum para a construção de novos saberes Segundo porque com a implantação da ISO 14000 dentro do hotel-escola SENAC, os professores passaram a ter uma visão voltada apenas para os temas mercadológicos e financeiros, deixando de lado o comprometimento de respeito ao meio ambiente.

Com isso, buscamos inserir a educação ambiental no curso como forma de idealizar a formação de um conhecimento capaz de articular teoria e prática, de unir, de agregar os setores práticos do hotel-escola que compõem o curso de gastronomia, através da integração dos conteúdos.

Percebemos que há necessidade do envolvimento de um maior número de pessoas, não somente da comunidade escolar, mas também dos profissionais que atuam nos setores de atividade prática-operacional do hotel-escola, para que se tenha um engajamento total, de todas as áreas do hotel, não se restringindo apenas ao departamento de alimentos e bebidas.

A preocupação com a questão do desperdício, anteriormente ao curso, visava apenas a contenção de despesas e não a conservação do meio ambiente. Não havia preocupação em abordar temas como o consumismo e gerações futuras. Percebemos que 
a equipe do hotel estava muito mais preocupada em dar retorno financeiro à instituição, e não voltava sua atenção para problemas ambientais mundiais. A questão financeira é importante em todo estabelecimento comercial, pois trata-se da sua manutenção no mercado em um mundo capitalista. Mas não podemos limitar a visão dos alunos, funcionários e professores apenas aos problemas locais que cercam a população do município de Águas de São Pedro.

Observamos, contudo, que há um hiato entre a formação profissional dos professores e a sua prática pedagógica cotidiana, que estava desvinculada completamente de temas que afetam diretamente a atuação profissional de cada um deles - no caso a crise ambiental. Assim, os problemas que afetam a cidade de Águas de São Pedro, as cidades vizinhas e o mundo não pareciam fazer parte da realidade deles.

A intenção do curso ministrado durante a realização do nosso trabalho foi fazer com que os professores buscassem uma abordagem ambiental associada ao conteúdo curricular, e trabalhassem explorando mais os alunos nas questões que tangem pesquisa prática e teórica, envolvendo a realidade culinária dos laboratórios e da comunidade local (do hotel-escola e da cidade), buscando novos canais dentro do próprio hotelescola e na comunidade, que resultassem em inserção social, disseminação da questão ambiental e troca de experiências locais.

Mas para isso, os professores deveriam trabalhar numa linha que permeasse a reflexão, porque uma das questões que pudemos observar durante os encontros é que esses profissionais têm uma formação exclusivamente voltada à atuação operacional, sendo que a própria característica do curso de gastronomia também faz com que eles se distanciem da reflexão, da leitura e da pesquisa. Acreditamos, assim, que o presente curso os auxiliou no exercício de ouvir, processar a informação e refletir a respeito do assunto discutido.

O objetivo dos encontros durante o workshop foi trabalhar os profissionais de forma que atuassem como pessoas reflexivas e com formação de comunidade de conflitos das questões da educação ambiental no curso de gastronomia. Portanto, não se tratava de repassar uma grande quantidade de conteúdos ou um programa extenso que contivesse muito além daquilo que os próprios professores ressaltaram na nossa pesquisa como relevante para ser trabalhado num primeiro momento, mas sim de conduzi-los a um processo em que eles pudessem estabelecer conexões entre a teoria e a prática, entre as crises globais e o universo pedagógico de cada um, na formação de futuros profissionais. 
Ressaltamos que os conhecimentos práticos vivenciados pelos professores devem ser articulados com os conhecimentos teórico-acadêmicos, podendo gerar a possibilidade de novas aberturas para a educação ambiental, principalmente porque o curso que nos serviu como objeto de pesquisa é um muito prático e envolve muita dinâmica nos diferentes departamentos da cozinha. Advertimos, durante os encontros, que as experiências práticas devem estar sempre munidas de reflexão e debate, permitindo a reabertura de novos caminhos.

Destacamos a necessidade de haver emergente mudança dentro do hotel-escola SENAC em que todos os envolvidos que por ali passam, seja na função de aluno, estagiário, funcionário ou hóspede, possam vivenciar um ambiente voltado para novos valores frente às questões da educação ambiental, de forma que todos, tomados por uma nova concepção de vida e de valores, possam ser sensibilizados a repensar seus padrões de vida cotidiana, mesmo porque a função do SENAC não é hoteleira e sim educacional, firmando-se, assim, o seu compromisso com a sociedade.

Percebemos que os professores demonstraram um otimismo em trabalhar novas condutas e valores no hotel-escola com relação aos alunos, aos próprios funcionários e aos hóspedes, demonstrando um compromisso e envolvimento com a educação ambiental, considerando-a extremamente atual e importante. Ficou clara a percepção dos mesmos em não poderem ficar à margem das necessidades do mundo atual, em que a dimensão ambiental é considerada um dos principais temas de discussão.

Percebemos que há necessidade de trabalhar a equipe do Grande Hotel de forma geral, envolvendo todos os níveis hierárquicos, buscando a adoção de novas atitudes referentes ao desperdício dos alimentos, considerando que esta seja uma filosofia que deva ser praticada por todos, abrangendo desde os diretores até os funcionários de nível básico dentro da instituição.

A atuação dos gerentes - ou melhor, líderes - deve estar baseada numa constante recriação a partir do que se estabelece na prática através do conhecimento das inúmeras possibilidades de técnicas que possam facilitar a ação do gestor - mas que não garantem o sucesso da prática. Portanto, a busca de novos saberes através da sua construção e permanente reconstrução é quesito fundamental dentro da atuação de um gerente, que deve buscar inovar novos modos de trabalho através de constantes reflexões e análises críticas quanto à sua prática e, no caso do hotel-escola, quanto às suas atitudes, que devem ser sempre de acordo com aquilo que é ensinado aos alunos. 
Outra questão observada por nós é que há uma filosofia da escola voltada para valores que permeiam princípios da educação ambiental, mas esta filosofia não se estende às áreas operacionais do hotel, o que faz parecer que estamos em duas instituições completamente diferentes, que promovem diversos valores e atitudes, gerando um desconforto para com os próprios profissionais do hotel-escola e uma confusão de valores para com os alunos, comprometendo a qualidade da formação profissional destes, que, como futuros profissionais, poderão repassar atitudes incorretas nos seus postos de trabalho quando estiverem atuando no mercado.

Dessa forma, ficou evidente que é necessário haver um curso para toda a equipe do hotel, uma vez que os alunos atuam diretamente juntos aos profissionais que ali trabalham.

$\mathrm{O}$ tema ambiental pareceu, num primeiro momento, descontextualizado e fragmentado do cotidiano da prática profissional dos professores e funcionários do hotel-escola. Mas depois do curso, se apresentou fundamental aos professores, uma vez que eles próprios foram percebendo que o tema em questão estava inerente à prática deles, ou melhor, a qualquer profissional, uma vez que o mesmo faz parte da complexidade do mundo.

Percebemos a sensibilização e o compromisso que os professores foram adquirindo no decorrer dos encontros no que diz respeito à importância de sempre recomeçar o processo educativo, já que o curso conta periodicamente com novos alunos - questão essa que antes dos encontros não acontecia, pois, como eles mesmos mencionaram, havia uma fragmentação de informação quanto aos temas ambientais de forma reducionista.

A proposta de trabalhar todos os alunos que passam pela formação profissional do hotel-escola é um projeto adequado e que tem o apoio da direção e da coordenação. Assim, pudemos constatar o empenho, a dedicação e a valorização, não somente dos professores, como também de toda a equipe escolar, de forma a possibilitar a viabilização do nosso projeto.

Levantamos alguns pontos já trabalhados pelo SENAC no quesito educação ambiental, aos quais atribuímos grande relevância para a formação profissional dos alunos, referentes à utilização de matéria-prima de boa qualidade, ao cozimento adequado dos alimentos, à conservação adequada dos alimentos pré-preparados, às técnicas de reaquecimento dos alimentos anteriormente cozidos, aos cuidados técnicos com o contato entre alimentos cruz e cozidos, à higiene na manipulação dos alimentos, à 
limpeza dos setores da cozinha, ao uso de água tratada, e à presença de um grupo de funcionários que atua na CIPA - Comissão Interna de Prevenção de Acidentes.

Percebemos, durante toda a intervenção, que os professores atuaram dinâmicos e interessados nos nossos encontros. Pudemos constatar, ainda, que a educação modifica as pessoas, abrindo novas possibilidades, novas atitudes e favorecendo a reflexão, de forma que essa transição possibilite a reconstrução de novos saberes, gerando novos conceitos e valores, despertando novos comportamentos e, finalmente, novas aprendizagens e novas práticas educativas.

A coordenação, assim como a direção, apoiou integralmente o nosso projeto, como também afirmou que este treinamento será levado para Campos do Jordão, com o objetivo de transformar a grade curricular do curso, como também de provocar uma reflexão mais aprofundada em torno do tema em questão.

No decorrer do nosso trabalho e durante todo o desenvolvimento do programa proposto pelo grupo, estivemos atentos em buscar dentre os participantes, alguns docentes que pudessem atuar como facilitadores dentro do hotel-escola de Águas de São Pedro, que desempenhassem a função de líderes potenciais, a fim de estimular a formação continuada do grupo, que aprendessem a desenvolver a sua liderança e estimulassem a formação de novas. As pessoas cujo perfil se adequava a tal atribuição tiveram seus nomes repassados para a coordenação, que cuidará para que o processo dentro da escola continue.

No entanto, o grupo de professores não soube que estávamos atentos em detectar pessoas que tivessem potencial para líder, pois tivemos o cuidado de não gerar competição, concorrência ou rivalidade entre eles.

E, finalmente, trabalhamos na reestruturação dos planos de ensino propostos inicialmente, de maneira que o conteúdo desenvolvido na formação profissional técnica possibilitasse formar pessoas reflexivas e que desenvolvessem práticas relacionadas ao tema ambiental. 


\section{RECOMENDAÇÕES}

Durante o desenvolvimento deste trabalho consideramos relevante o incentivo de investimentos locais, de forma que revertesse em benefícios para a própria população, já que o hotel-escola poderia ser um local atrativo de visitas técnicas e projetos pedagógicos. Para o desenvolvimento desses projetos, haveria uma parceria entre a instituição e a ESALQ/USP já que a proximidade do hotel-escola à cidade de Águas de São Pedro facilitaria esse contato. Ressaltamos também que a equipe do hotel-escola precisa se integrar através de um envolvimento maior na atividade prática-pedagógica, de forma que haja uma unidade através de uma filosofia única da instituição. Essa unidade seria possível por meio de cursos que possibilitassem a inserção de novos valores na equipe prática-teórica do Grande Hotel SENAC de Águas de São Pedro.

Os funcionários do Grande Hotel de Águas de São Pedro precisam estar engajados numa única linha de formação profissional junto aos alunos, uma vez que estes carecem de cursos de formação na área educacional que os motivem a rever os seus valores e atitudes, buscando uma unificação de procedimentos, para favoreça sua formação completa, de maneira que as informações lhes sejam repassadas de forma integral e que os professores envolvidos formem uma corrente para uma única vertente de pensamento, resultando em coerência e harmonia nas formas de proceder frente às questões do dia-a-dia.

Engajada nas informações repassadas aos alunos como resultado de cursos, encontros e reuniões, a coordenação das equipes que trabalham diretamente na formação dos alunos - seja de âmbito prático ou teórico - deve se preocupar em despertar uma sintonia entre os grupos, que permeie o espírito de equipe, gerando sentimentos voltados para o respeito, a solidariedade, a sensibilidade, a cooperação, o comprometimento, de maneira que sirva de exemplo aos futuros profissionais que ali buscam a sua formação para ingressarem no mercado de trabalho.

Quanto à aquisição de matéria prima, mencionada durante os encontros, sugerimos que haja um envolvimento dos fornecedores para reavaliar a necessidade das 
embalagens atuais, de forma que busquem em conjunto alternativas que possam favorecer o meio ambiente, sem prejudicar os produtos.

A unidade educacional deveria, ainda, promover uma campanha envolvendo os professores e o departamento pessoal, de maneira que o uso de produtos químicos (álcool, detergente, sabão em pó, sabão em pedra, desinfetante, sapólio) para a higienização de todas as áreas do hotel-escola fossem usados de forma consciente, e que buscasse, através da campanha, esclarecer toda a equipe de funcionários sobre os reflexos do uso dos mesmos em abundância.

Outro tema que poderia ser incorporado à campanha acima mencionada é a questão do uso desmedido de copos descartáveis, uma vez que o SENAC buscou racionalizar o uso dos descartáveis através da distribuição de canecas, mas não promoveu junto aos funcionários uma mudança de hábito dos mesmos, carecendo de esclarecimentos e ações que visem uma mudança de atitude das pessoas envolvidas.

\subsection{Pesquisas futuras}

- Alertamos a equipe educacional do SENAC de Águas de São Pedro quanto à necessidade de continuidade do processo de conscientização e engajamento em relação às questões voltadas para a educação ambiental dentro da formação profissional dos alunos, e no exercício diário do corpo docente, operacional e de gestão do hotel-escola;

- Sugerimos uma pesquisa quantitativa, principalmente na questão do desperdício de resíduos, através de mensuração por meio de peso e foto, de maneira a quantificar as sobras;

- Sugerimos que houvesse um trabalho quanto às possibilidades de mudança de paradigmas do hotel-escola SENAC, envolvendo não somente alunos e professores de todos os níveis de ensino, mas também estagiários, visitantes de escolas e empresas, funcionários das diversas áreas do hotel e da faculdade, hóspedes, passantes e fornecedores;

- Seria muito importante, ainda, pesquisar as contribuições que a série da ISO 14000 gera em relação ao cotidiano das empresas, frente às questões ambientais. 


\section{REFERÊNCIAS}

AFONSO, A.J.; ANTUNES, F. (2001). Educação, cidadania e competividade: questões em torno de uma nova agenda. Cadernos de Pesquisa, São Paulo, n. 113, jul. Disponível em: $<$ http://www.scielo.br/scielo.php?script $=$ sci_arttext\&pid=S010015742001000200005\&lng=en\&nrm=iso>. Acesso em: 19 ago. 2005.

ALAMO, J.B.D. (1992). Paisaje y educación ambiental: evalución de câmbios de actitudes hacia el entorno. Madrid: Secretaría de Estado para las Políticas del Agua y el Medio Ambiente. Ministério de Obras Públicas y Transportes.

ALARCÃO. I. (Org.). (1996). Formação reflexiva de professores: estratégias de supervisão. Porto: Porto.

ALVES, F.L. (2001). Educação ambiental e educação para a cidadania. OLAM Ciência e Tecnologia, Rio Claro, v.1, n.1, .

ANDRÉ, M. (1995). Etnografia na prática escolar. Campinas: Papirus.

ARAÚJO, U.F. (2003). Temas transversais e a estratégia de projetos. São Paulo: Moderna.

BÖHM, G.M.B. (2002). Um estudo com alunos do CEFET/RS sobre energia elétrica e ambiente, enfatizando a educação ambiental. Dissertação (Mestrado) Universidade Federal do Rio Grande, Florianópolis, 2002.

BRASIL (1999). Lei nº 9.795, de 27 de abril de 1999. Política nacional de educação ambiental. Diário Oficial da União, Brasília, DF, 28 abr.

BRASIL (1997). Parâmetros curriculares nacionais. Brasília: Ministério da Educação e Desporto/Secretaria do Ensino Fundamental.

BRASIL (1996). Lei n 9.394, de 20 de dezembro de 1996. Diretrizes e bases da educação nacional. Diário Oficial da União, Brasília, DF, 23 dez. 
BRASIL (1988). Constituição da República Federativa do Brasil. Brasília, DF: Senado.

BRASIL (1981). Lei $n^{\circ} 6.938$, de 31 de agosto de 1981. Política nacional de meio ambiente. Diário Oficial da República Federativa do Brasil, Brasília, DF.

BUSQUETS, M.D.; LEAL, A. (1999). Temas trasnversais em educacao: bases para uma formacao integral. 5.ed. Sao Paulo: Atica.

BRUNER, J. (1997). Actos de significado. Lisboa: Ed.70.

CAMARGO, R.B.A. (1990). Estância hidromineral de Águas de São Pedro: guia turístico e medicinal. São Paulo: SENAC/DR.

CAPRA, F. (2000). O Ponto de mutação: a ciência, a sociedade e a cultura emergente. 7.ed. São Paulo: Cultrix.

. (2002). As conexões ocultas e ciência para uma vida sustentável. Tradução de Marcelo Brandão Cipolla. São Paulo: Cultrix.

CARON, C.; ROCHE, S. (2001). Vers une typologie des représentations spatiales. l'Espace géographique, Paris, v.1, n.1. p.1-12.

CARVALHO, I.C.M. (2004). Educação ambiental crítica: nomes e endereçamentos da educação. In: LAYRARGUES, P.P. (Coord.). Identidades da educação ambiental brasileira. Brasilia: Ministério do Meio Ambiente. p.13-24.

CASCINO, F. (1999). Educação Ambiental: princípios, história, formação de professores. São Paulo: Editora SENAC São Paulo.

CASCINO, F. (1998). Educação ambiental- eixos teóricos para uma reflexão curricular. In: CASCINO, F.; JACOB, P.; OLIVEIRA, J.F. (Org.). Educação, meio ambiente e cidadania: reflexões e experiências. São Paulo: SMA/CEAM. p.15- 22. 
CASTRO, R.S.; BAETA, A.M.B. (2002). Autonomia intelectual: condição necessária para o exercício da cidadania. In: LOUREIRO, C.F.B.; LAYRARGUES, P.P.;

CASTRO, R.S.C. (Org.). Educação ambiental: repensando o espaço da cidadania. 2.ed. São Paulo: Cortez. p.99-107.

CINTERFOR (1996). Boletin Técnico Interamericano de Formación Profesional, Montevidel, n.136, jul./sept.

COLE, D.N. (1993). Minimizing conflict between recreation and nature conservation. In: SMITH, D.S.; HELLMUND, P.C. (Ed.). Ecology of greenways. Minneapolis: University of Minnesota. p.105-122.

CONSELHO ESTADUAL DE EDUCAÇÃO (1997). Deliberação CEE nº 14, de $1^{\circ}$ de outubro de 1997. Diretrizes para a educação profissional no sistema de ensino do Estado de São Paulo. Presidente: Bernadete Angelina Gatti. Diário Oficial do Estado. São Paulo, 3 out. Seção I, p.13.

CRAWFORD, R. (1994). Na era do capital humano: o talento, a inteligência e o conhecimento como força econômica, seu impacto nas empresas e nas decisões de investimento. São Paulo: Atlas.

CUNHA, L.A. (1989). A Universidade crítica. 2.ed. Rio de Janeiro: Francisco Alves.

CURSO DE FORMAÇÃO DE FORMADORES PARA FORMAÇÃO DE PROFISSIONAIS (1998). Documento. São Paulo: CEEP.

DALMÁS, G. (1998). O conceito filosófico de ambiente e a reconstrução da subjetividade ética: uma contribuição à educação ambiental. Dissertação (Mestrado) Universidade Federal do Rio Grande, Florianópolis, 1998.

DEMO, P. (1997). A nova LDB - ranços e avanços. Campinas: Papirus. (Coleção Magistério: Formação e Trabalho Pedagógico). . (1998). Educação e qualidade. 4.ed. São Paulo: Papirus. 
. (2001). Participação é conquista. 5.ed. São Paulo: Cortez.

DEPARTAMENTO NACIONAL (1990). Formação profissional. Boletim Técnico do SENAC, Rio de Janeiro, v.16, n.3, set./dez.

. (1996). Uma proposta para o setor de comércios e serviços. Rio de Janeiro: Formação Profissional; SENAC.

FAZENDA, I.C.A. (1993). Práticas interdisciplinares na escola. 2.ed. São Paulo: Cortez.

. (1992). Integração e interdisciplinaridade no ensino brasileiro: efetividade ou ideologia. São Paulo: Loyola.

FIDALGO, F.S. (2000). A formação profissional negociada: França e Brasil, anos 90. São Paulo: Anita Garibaldi.

FONTES, P.J. (2003). Educação pela e para a ação ambiental. In: SATO, M.;

SANTOS, J.E. (Org.). A contribuição da educação ambiental à esperança de Pandora. São Carlos: RIMA. p.355-365.

FRANCO, M.L.P.B. (1994). Ensino médio: desafios e reflexões. Campinas: Papirus. (Coleção Magiastério, Formação e Trabalho Pedagógico).

FREITAS, G.G.C.; FREITAS, D. (2003). Analise no grau de ambientalização curricular no curso de licenciatura em pedagogia da Universidade Federal de São Carlos. In: ENCONTRO PESQUISA EM EDUCAÇÃO AMBIENTAL: ABORDAGENS EPISTEMOLÓGICAS E METODOLÓGICAS., 2., 2003, São Carlos. Anais... São Carlos: UFSCar. Cd- Rom.

FRIGOTTO, G. (1997) . A Escola como ambiente de aprendizagem. In: CASALI, A. (Org.). Empregabilidade e educação: novos caminhos no mundo do trabalho. São Paulo: Educ. p.139-150. 
GIU, A.C. (1987). Como elaborar projetos de pesquisa. São Paulo: Atlas.

GIULIANI, A.C. (1994). Educação e trabalho: revalorizando os cursos técnicos profissionalizantes na virada do século. Dissertação (Mestrado) - Universidade Metodista de Piracicaba, Piracicaba, 1994.

GUERRA, A.F.S. (2003). Navegando na web em busca de intervenções em educação ambiental: a interdisciplinaridade e a transversalidade em ação. In : SATO, M.; SANTOS, J.E. (Org.). A contribuição da educação ambiental à esperança de Pandora. São Carlos: RIMA. p.301-325.

GUERRA, A (2002). Projeto educado: a educação ambiental em áreas costeiras a partir de um ambiente de parendizagem cooperativa. OLAM - Ciência e Tecnologia, Rio Claro, v.1, n.1.

GUIMARÃES, M. (1995). A dimensão ambiental na educação. Campinas: Papirus. . (2004a). A formação de educadores ambientais. Campinas: Papirus. . (2004b). Educação ambiental crítica. In: LAYRARGUES, P.P. (Coord.). Identidades da educação ambiental brasileira. Brasilia: Ministério do Meio Ambiente. p.25-34.

HINGEL, M.A. (1993). Lei de diretrizes e bases da educação nacional: síntese histórica do Projeto de Lei e Depoimento do Ministro da Educação na Comissão da Educação no Senado. Atualidade em Educação, Rio de Janeiro, n.37, p.3-22, nov./dez.

INTERNATIONAL ORGANIZATION OF STANDARTIZATIO (2006). ISO 14000 Gestão ambiental. Disponível em:<www.cnpma.embrapa.br/ projetos/prod int/iso 14000.html >. Acesso em: 25 Oct. 2006.

IVERS, I. (2000). Serviço Nacional de Aprendizagem Industrial - SENAI: análise de relatórios anuais (1990-1998). Dissertação (Mestrado) - Universidade Metodista de Piracicaba, Piracicaba, 2000.. 
JACOBI, P. (1997). Meio ambiente e sustentabilidade: alguns elementos para reflexão. In: CAVALCANTI, C. (Org.). Meio ambiente, desenvolvimento sustentável e políticas públicas. São Paulo: Cortez.

JAPIASSÚ, H. (1976). Interdisciplinaridade e patologia do saber. Rio de Jaeniro: Imago.

KUENZER, A .(1997). Ensino médio e profissional: as políticas do estado neoliberal. São Paulo: Cortez.

LAYRARGUES, P.P. (Coord.). (2004). Identidades da educação ambiental brasileira. Brasília: Ministério do Meio Ambiente; Diretoria de Educação Ambiental. . (2002). A conjuntura da institucionalização da política nacional de educação ambiental. OLAM - Ciência e Tecnologia, Rio Claro, v.1, n.1.

LE BERRE, M. (1992). Territoires. In: BAILLY et. al. Encyclopédie de Geógraphie. Paris: Econômica.

LEFF, E. (1997). La educación ambiental en la encrucijada de la globalización. Conocimiento y Educación Ambiental, v.8, n.18, mar. . (2001). Educação ambiental e desenvolvimento sustentable. In: REIGOTA, M. (Org.). Verde cotidiano o meio ambiente em discussão. 2.ed. Rio de Janeiro: DP\&A. p.111-129.

LEME, T.N. (2006). Os conhecimentos praticos dos profesores: (re)abrindo caminhos para a educação ambiental na escola. São Paulo: Annablume.

LIMA, G.F.C. (2002). Crise ambiental, educação e cidadania: os desafios da sustentabilidade emancipatória. In: LOUREIRO, C.F.B.; LAYRARGUES, P.P.; CASTRO, R.S.C. (Org.). Educação ambiental: repensando o espaço da cidadania. 2.ed. São Paulo: Cortez. p.109-141. 
LOPES, O. (1990). Planejamento do ensino numa perspectiva crítica da educação. In: . (Org.). Repensando a didática. 4.ed. Campinas: Papirus.

LOUREIRO, C.F.B. (2002). Educação ambiental e movimentos sociais na construção da cidadania ecológica e planetária. In: LOUREIRO, C.F.B.; LAYRARGUES, P.P.; CASTRO, R.S.C. (Org.). Educação ambiental: repensando o espaço da cidadania. 2.ed. São Paulo: Cortez. p.69-98.

LÜDKE, M.; ANDRÉ, M.E.D.A. (1986). Pesquisa em educação: abordagens qualitativas. São Paulo: EPU.

MANFrinAtO, M.H.V. (2002). Grande Hotel São Pedro - Hotel Escola Senac: origens - trajetória. Dissertação (Mestrado) - Universidade Metodista de Piracicaba, Piracicaba, 2002.

MAYER, M. (1998). Educación ambiental: de la acción a la investigación. Enseñanza de lãs Ciências, Barcelona, v.16, n.2, p.217-2 31.

MINISTÉRIO DA EDUCAÇÃO E CULTURA (1979). Legislação e normas do ensino de $2^{\circ}$ grau. Brasília: MEC/Secretaria de Ensino de $1^{\circ}$ e $2^{\text {a }}$ Graus. . (1996). Parâmetros curriculares nacionais. Brasília: MEC. . (1998). A implantação da educação ambiental no Brasil. Brasília: MEC/Coordenação de Educação Ambiental.

MEDINA, N.M. (1997). Breve histórico da educação ambiental. In: PADUA, S.M.;

TABANEZ, M.F. (Org.). Educação ambiental: caminhos trilhados no Brasil. Brasília: IPÊ. p.119-131. . (2002). Educação ambiental: a construção de novos valores éticos. OLAM Ciência e Tecnologia, Rio Claro. v.1, n.1. 
MEO, G.D. (1991). De L'espace subjectif à l'espace objectif: l'itinéraire du labyrinthe. L'Espace Géographique, Paris, n.4, p.359-373.

MOTA, D. (1997). SENAC/DN - formação e trabalho - uma viagem pela história do trabalho. Rio de Janeiro: SENAC Nacional.

MORIN, E. (1997). Complexidade e ética da solidariedade. In: CASTRO, G.; CARVALHO, E.A.; ALMEIDA, M.C. (Org.). Ensaios de complexidade. Porto Alegre: Sulina.

. (2000). Saberes globais e saberes locais: o olhar transdisciplinar. Rio de Janeiro: Garamond.

NASCIMENTO, A.N.; CAMARGO, J.C.G. (2002). Desenvolvimento sustentável e meio ambiente. OLAM - Ciência e Tecnologia, Rio Claro, v.1, n.1.

NOAL, F.O. (2003). Ciência e interdisciplinaridade: interfaces com a educação ambiental. In: SATO, M.; SANTOS, J.E. (Org.). A contribuição da educação ambiental à esperança de Pandora. São Carlos: RIMA. p.369-387.

PEGORARO, J.L. (2003). Atividades educativas ao ar livre: um quadro a partir de escolas públicas da região de Campinas e dos usos de área úmida urbana com avifauna conspícua (Minipantanal de Paulínia - SP). Tese (Doutorado) - Escola de Engenharia de São Carlos, Universidade de São Paulo, São Carlos, 2003.

PEREZ, J.G. (2003). Formación técnico-profesional desde los modelos de competências de acción y los ciclos de desarrollo profesional. In: FORO NACIONAL SOBRE LA INCORPORACIÓN DE LA PERSPECTIVA AMBIENTAL EM LA FORMACIÓN TÉCNICA Y PROFESIONAL, 2003, México. Anales... Mexico: Universidade Autônoma de San Luis. Cd- Rom.

PETEROSSI, H.G. (1980). Educação e mercado de trabalho: análise critica dos cursos de tecnologia. São Paulo: Loyola. (Coleção Realidade Educacional, 7). 
PRATES, K.V.M.C. (2003). Uma proposta de ensino - aprendizagem sobre biodiversidade para estudantes do terceiro ciclo do ensino fundamental. Tese (Doutorado) - Escola de Engenharia de São Carlos, Universidade de São Paulo, São Carlos, 2003

REIGOTA, M. (2001). Meio ambiente e representação social. 4.ed. São Paulo: Cortez.

REIS, U.A.; RODRIGUES, A.; VIEIRA, É . (1985). Educação e produtividade. Salvador: Fundação Emílio Odebrecht; Rio de Janeiro : Forense Universitária.

RIEMMA, J.C. (1979). Apontamentos para a história do DR-SENAC/ SP - 27. São Paulo: SENAC.

ROCHA, A.S.A. (1997). As Tranformações educativas do serviço nacional de aprendizagem industrial-SENAI-SP. Tese (Doutorado) - Pontifícia Universidade Católica, São Paulo, 1997.

ROMANELLI, O. (1998). História da educação no Brasil (1930/1973). 21.ed. Petrópolis: Vozes.

RUSCHEINSKY, A. (2004). Atores sociais e meio ambiente: a mediação da ecopedagogia. In: LAYRARGUES, P.P. (Coord.). Identidades da educação ambiental brasileira. Brasilia: Ministério do Meio Ambiente. p.51-63.

SACHES, I. (1996). El desafío ambiental. In: SALOMÓN, J.J. et al. Una búsqueda incierta: ciência, tecnologia y desarrollo. Cidade do México: Cide.

SANTOS, G.G.S. (2004). Educação ambiental em curso de formação de professores: concepções de docentes do curso de pedagogia - anos iniciais do ensino fundamental da FURG. Dissertação (Mestrado) - Universidade Federal do Rio Grande, Florianópolis, 2004. 
SANTOS, R.F.; REIGOTA, M.; RUTKOWISK, E. (2003). Educação e planejamento ambiental: uma relação conceitual. In: SATO, M.; SANTOS, J.E. (Org.). A contribuição da educação ambiental à esperança de Pandora. São Carlos: RIMA. p.225-242.

SANTOS, J.E.; SATO, M. (2003). Um breve itinerário pela educação ambiental. In: SATO, M.; SANTOS, J.E. (Org.). A contribuição da educação ambiental à esperança de Pandora. São Carlos: RIMA. p.1-10.

. (2003). Universidade e ambientalismo - encontros não são despedidas. In:

SATO, M.; SANTOS, J.E. (Org.). A contribuição da educação ambiental à esperança de Pandora. São Carlos: RIMA. p.31-49.

SATO, M. et al. (2001). Ciências, filosofia e educação ambiental - links e deleites, OLAM - Ciência \& Tecnologia, Rio Claro, v.1, n.1, ago.

SAUVÉ, L. (1997). Educação ambiental e desenvolvimento sustentável: uma análise complexa. Revista de Educação Pública, v.6, n.10. Disponível

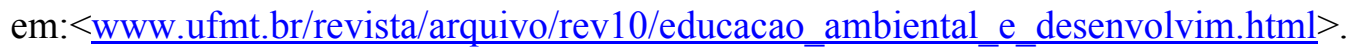
Acesso em: 25 abr. 2005.

. (2003). Perspectivas curriculares para la formación de formadores em educación ambiental. In: FORUM NACIONAL SOBRE LA INCORPORACIÓN DE LA PERSPECTIVA AMBIENTAL EM LA FORMACIÓN TECNICA Y PROFESIONAL, 2003, México. Anales... México: Universidad Autônoma de San Luis Potosí. CD-Rom.

SAVIANI, D. (1998). Da nova LDB ao novo plano nacional de educação: por uma outra política educacional. Campinas: Autores Associados.

SCHALCH, V.; LEITE, W.C.A. (2000). Resíduos sólidos (lixo) e meio ambiente. In : CASTELlANO, E.G.; CHAUDHRY, F.H. (Org.). Desenvolvimento sustentado: problemas e estratégias. São Carlos: EESC-USP. p.107-135. 
SERVIÇO BRASILEIRO DE APOIO ÀS MICRO E PEQUENAS EMP[RESAS (19--).

Formação de Jovens Empreendedores. São Paulo: SEBRAE/CEETEPS/UNIMEP.

SERVIÇO NACIONAL DE APORENDIZAGEM COMERCIAL (2000). Formulação da proposta estratégica. São Paulo: Administração Regional do Estado de São Paulo. p. $24-28$.

. (1997). Instituição, regulamento e regimento. São Paulo: Administração Regional do Estado De São Paulo. p.96.

. (2001). Pesquisa preliminar para identificação do perfil do aluno/cliente.

São Pedro: Centro de Educação em Turismo e Hotelaria - SENAC e da Faculdade

SENAC de Turismo e Hotelaria de Águas de São Pedro.

SERRANO, C.; BRUHNS, H.T.; LUCHIARI, M.T. (Orgs.). (2000). Olhares contemporâneos sobre o turismo. Campinas: Papirus.

. (2002). Desenvolvimento sustentável e participação: algumas reflexões em voz alta. In: LOUREIRO, C.F.B.; LAYRARGUES, P.P.; CASTRO, R.S.C. (Org.).

Educação ambiental: repensando o espaço da cidadania. 2.ed. São Paulo: Cortez. p.15-21.

- (1998). De Tbilisi a Thessaloniki: a educação ambiental no Brasil. In: CASCINO, F.; JACOBI, P.; OLIVEIRA, J.F. (Org.). Educação, meio ambiente e cidadania: reflexões e experiências. São Paulo: SMA/CEAM.

SOUZA, P.N.P.; SILVA, E.B. (1997). Como entender e aplicar a nova LDB: lei ${ }^{\circ}$ 9394/96. São Paulo: Pioneira.

SOUZA SANTOS, B. (19--). Pela mão de Alice: o social e o político na pósmodernidade. 3.ed. São Paulo: Cortez.

SÚCAR, S. (2003). Educação ambiental e meio ambiente: concepções de profissionais da educação. In: ENCONTRO DE PESQUISA EM EDUCAÇÃO AMBIENTAL: 
abordagens epistemológicas e metodológicas. 2., 2003, São Carlos. Anais... São Carlos: UFSCar. Cd- Rom.

. (2003). La Fomación de los profesores: proceso fundamental para una educación ambiental. La experiência de la Universidad de Guanajuato. In: FORO NACIONAL SOBRE LA INCORPORACIÓN DE LA PERSPECTIVA AMBIENTAL EM LA FORMACIÓN TÉCNICA Y PROFESIONAL, 2003, México. Anales... Mexico: Universidade Autônoma de San Luis Potosí. Cd- Rom.

STARK, R.E . (2000). A Organização do ensino profissional de nível médio no CEETEPS após a lei no 9394/96. Dissertação (Mestrado) Universidade Metodista de Piracicaba, Piracicaba, 2000.

STOREY, C. et al. (2002). Intervenção escola e comunidade: os desafios da transversalidade no contexto de uma experiência /amazônica. OLAM - Ciência e Tecnologia, Rio Claro, v.1, n.1.

SZAJMAN, A . (2001). A Visão de futuro - proposta estratégica 2001/2001. Revista SENAC SP, São Paulo, ano 5, n.17, p.8, abr./jun.

UHLE, A.B. (1982). O Exercício da docilidade - estudo da formação profissional do SENAC. Dissertação (Mestrado) - Universidade de Campinas, Campinas, 1982.

TEIXEIRA, E.C. (2001). O local e o global: limites e desafios da participação cidadão. São Paulo: Cortez; Recife: EQUIP; Salvador: UFBA.

TRISTÃO, M. (2004). A educação ambiental na formação de professores: redes de saberes. São Paulo: Annablume; Vitória: Facitec.

TYLER, D.; GUERRIER,Y.; ROBERTSON, M. (2001). Gestão de turismo municipal. São Paulo: Futura.

WAEHNELDT, A.B.A. (1996). O SENAC e a educação ambiental. Boletim Técnico do Senac, Rio de Janeiro, v.22, n.3. Disponível 
em: $<$ http://www.senac.br/informativo/BTS/223/boltec223b.htm $>$. Acesso em: 12 maio 2005. 
APÊNDICE A - Formulário de levantamento do perfil do corpo docente do curso de cozinheiro

Nome:

Idade:

Estado Civil:

Local de residência:

Escolaridade:

Profissão anterior ao curso:

Perspectiva de carreira dentro da área gastronômica: 
APÊNDICE B - Formulário de levantamento do perfil do corpo discente do curso de cozinheiro

Nome:

Idade:

Estado Civil:

Local de residência:

Escolaridade:

Profissão anterior ao curso:

Perspectiva de emprego dentro da área gastronômica: 
APÊNDICE C - Questionário aplicado à coordenação para investigar a inserção do tema ambiental no curso de gastronomia.

1- O que você entende por meio ambiente?

2- Você já ouviu falar em educação ambiental ?
( ) $\operatorname{sim}$
( ) não
( ) mais ou menos
( ) não sei

O que você entende por esse termo ?

3- A Política Nacional de Educação Ambiental (Lei 9795/99) afirma em seu artigo $2^{\circ}$ que "a educação ambiental é um componente essencial da educação nacional, devendo estar presente, de forma articulada, em todos os níveis e modalidades do processo educativo, em caráter formal e não formal". Você considera necessário/ importante a inserção do tema ambiental no curso de cozinheiro?
( ) $\operatorname{sim}$
( ) não
( ) mais ou menos
( ) não sei

Comente

4- A proposta pedagógica do curso contempla de alguma forma, temas ambientais?

5- Em seu artigo $10,1^{\circ}$ parágrafo, a lei 9795/99 afirma ainda que "a educação ambiental não deve ser implantada como disciplina específica no currículo de ensino", mas deve estar presente em todas as disciplinas da grade curricular.Você vê alguma possibilidade de integrar a temática ambiental no curso de cozinheiro?
( ) $\operatorname{sim}$
( ) não
( ) mais ou menos
( ) não sei

Se sim, de que forma? 
6- Os planos de ensino dos docentes do curso de cozinheiro básico contemplam a temática ambiental de alguma forma?
( ) $\operatorname{sim}$
( ) não
( ) mais ou menos
( ) não sei

De que forma?

7- As práticas pedagógicas dos docentes do curso de cozinheiro básico contemplam a temática ambiental de alguma forma?
( ) $\operatorname{sim}$
( ) não
( ) mais ou menos
( ) não sei

De que forma?

8- Você tem alguma sugestão para a integração da temática ambiental no curso de cozinheiro ? Qual ? 
APÊNDICE D - Questionário aplicado aos professores para investigar a inserção do tema ambiental no curso de gastronomia.

1- O que você entende por meio ambiente?

2- Você já ouviu falar em educação ambiental ?
( ) $\operatorname{sim}$
( ) não
( ) mais ou menos
( ) não sei

O que você entende por esse termo?

3- A Política Nacional de Educação Ambiental (Lei 9795/99) afirma em seu artigo $2^{\circ}$ que "a educação ambiental é um componente essencial da educação nacional, devendo estar presente, de forma articulada, em todos os níveis e modalidades do processo educativo, em caráter formal e não formal". Você acha que a questão ambiental tem alguma ligação com a sua profissão?
( ) $\operatorname{sim}$
( ) não
( ) mais ou menos
( ) não sei

Comente

4- Em seu artigo $10,1^{\circ}$ parágrafo, essa mesma lei afirma ainda que "a educação ambiental não deve ser implantada como disciplina específica no currículo de ensino", mas deve estar presente em todas as disciplinas da grade curricular. Você acha que a questão ambiental tem alguma ligação com a disciplina que você leciona?
( ) $\operatorname{sim}$
( ) não
( ) mais ou menos
( ) não sei

Comente

5- No plano de ensino da disciplina que você leciona, está prevista a abordagem do tema ambiental de alguma forma?
( ) $\operatorname{sim}$
( ) não
( ) mais ou menos
( ) não sei 
Comente

6- Dentro da sua prática pedagógica, existe uma preocupação com a temática ambiental?
( ) $\operatorname{sim}$
( ) não
( ) mais ou menos
( ) não sei

Se sim, de que forma, ela acontece?

Existe alguma dificuldade para a inserção do tema nas práticas de ensino? Qual?

7 - Você vê alguma possibilidade de integrar a questão ambiental na disciplina que leciona?
( ) $\operatorname{sim}$
( ) não
( ) mais ou menos
( ) não sei

Quais ? Através de quais temas? Comente:

8 - Você teria interesse em participar de um curso cuja finalidade seria a incorporação de temas ambientais na prática profissional do cozinheiro?
( ) $\operatorname{sim}$
( ) não
( ) mais ou menos
( ) não sei

Sugestões: 
APÊNDICE E - Questionário aplicado aos alunos para investigar a inserção do tema ambiental no curso de gastronomia.

1- O que você entende por meio ambiente?

2- Você já ouviu falar em educação ambiental ?
( ) $\operatorname{sim}$
( ) não
( ) mais ou menos
( ) não sei

O que você entende por esse termo ?

3- A Política Nacional de Educação Ambiental (Lei 9795/99) afirma em seu artigo $2^{\circ}$ que "a educação ambiental é um componente essencial da educação nacional, devendo estar presente, de forma articulada, em todos os níveis e modalidades do processo educativo, em caráter formal e não formal". Você acha que a questão ambiental tem alguma ligação com a sua profissão?
( ) $\operatorname{sim}$
( ) não
( ) mais ou menos
( ) não sei

Comente

4- Em seu artigo $10,1^{\circ}$ parágrafo, essa mesma lei afirma ainda que "a educação ambiental não deve ser implantada como disciplina específica no currículo de ensino", mas deve estar presente em todas as disciplinas da grade curricular. Alguma disciplina que compõe o curso de cozinheiro trabalha a questão ambiental ?
( ) $\operatorname{sim}$
( ) não
( ) mais ou menos
( ) não sei

Quais disciplinas ? De que forma elas trabalham essa temática?

5- Quais sugestões você daria para a incorporação do tema ambiental nas disciplinas do curso? 
6- Quais sugestões você daria para a incorporação do tema ambiental na prática profissional do cozinheiro? 
APÊNDICE F - Programação do Curso de Formação dos Professores

Objetivos do curso:

1 - Proporcionar uma reflexão e um debate a respeito do tema meio ambiente e educação ambiental e da sua importância e inserção na formação profissional do cozinheiro.

2 - Construir uma grade curricular que englobe o tema ambiental de forma transversal.

- Encontro 1 - (05/10/05) Apresentação do programa do workshop e dos resultados dos questionários aplicados aos alunos, à coordenação e aos professores.

- Encontro 2 -(19/10/05) Construção do conceito de meio ambiente.

- Encontro 3 - (26/10/05) Construção do conceito de educação ambiental.

- Encontro 4 - (09/11/05) A questão ambiental e o profissional da cozinha. Alguns temas relevantes: uso de recursos renováveis.

- Encontro 5 - (23/11/05) Alguns temas relevantes: desperdício, reaproveitamento, lixo e reciclagem.

- Encontro 6 - (07/12/05) Consumo responsável.

- Encontro 7 - (14/12/05) Educação ambiental: Perspectiva de Racionamento ou Dimensionamento

- Encontro 8 - (01/02/06) Alguns temas relevantes: Racionalidade no uso de embalagens: respeito ao meio ambiente .

- Encontro 9 - (15/02/06) Valores da educação ambiental

- Encontro $10-(01 / 03 / 06)$ Novas posturas nas práticas profissionais

- Encontro 11 - (15/03/06) Iniciativa de Gestão Ambiental no SENAC

- Encontro 12 - (29/03/06) O papel do professor do curso de cozinheiro e a construção da grade curricular ambientalizada.

- Encontro 13 - (12/04/06) A construção da grade curricular ambientalizada.

- Encontro 14 - (26/04/06) Avaliação do workshop. 
APÊNDICE G - Roteiro de questões de avaliação final com os professores.

01. Você já começou a trabalhar/ aplicar a questão ambiental na grade curricular do curso de cozinheiro?

02. Você sentiu dificuldade em trabalhar com a questão ambiental? Quais?

03. Você acredita que os conceitos de meio ambiente que foram trabalhados em sala de aula, estejam sendo implantados dos departamentos da cozinha? Como?

04. Você percebeu uma mudança da postura dos professores depois da realização do workshop?

05. Depois do workshop sobre o tema ambiental na área gastronômica, da inserção desse tema na grade curricular e da reformulação do plano de ensino das aulas que você ministra, você notou alguma mudança de postura na sua vida pessoal?

06. Com a reformulação da grade curricular, você acha que houve alguma mudança na idéia que você tinha sobre a relação entre a questão ambiental e a profissão de cozinheiro?

07. Os alunos quando chegam para o curso técnico tem clara a correlação da futura profissão com o tema em questão?

08. Você acredita que o workshop tenha contribuído para deixar claro o seu papel, enquanto professor e como formador de opinião a respeito da relevância do tema ambiental na área de gastronomia? 
APÊNDICE H - Questionário de avaliação do curso aplicado aos professores.

01. Você considera que o treinamento modificou seu entendimento sobre o meio ambiente? Explique.

02. Você considera que o tema ambiental tenha alguma ligação com a área de gastronomia? Em que aspectos? Justifique a sua resposta.

03. O treinamento trouxe alguma clareza a respeito de que forma o tema ambiental pode ser inserido na grade curricular do curso? Justifique.

04. Você considera que o tema ambiental possa fazer parte integrante das disciplinas que você ministra? Por quê?

05. "A profissão na área de serviços depende do meio ambiente, e de forma especial, a gastronomia está inserida neste contexto", como você poderia explicar esta afirmação a partir dos encontros realizados durante o workshop?

06. A partir da realização do workshop, o plano de ensino do curso de gastronomia foi refeito pelos professores. Você considera que a reformulação deste documento, buscando a inserção do tema ambiental, proporciona aos alunos e ao corpo docente uma nova postura com relação a esse assunto? Justifique.

07. Após a realização do workshop existe alguma dificuldade para a inserção do tema nas práticas de ensino? Qual? 
08. Sugestões. 
APÊNDICE I - Questionário de avaliação final aplicado aos alunos do Curso de Cozinheiro.

1- O que você entende por meio ambiente?

2- O que você entende por educação ambiental?

3- Você acha que a questão ambiental tem alguma ligação com a sua profissão?Comente

4- Alguma disciplina que compõe o curso de cozinheiro trabalhou a questão ambiental? Qual (is)? De que forma elas trabalharam essa temática?

5- Quais assuntos ligados ao tema ambiental foram incorporados nas disciplinas do curso?

6- Houve algum tema ligado ao meio ambiente que você considera relevante e que não foi abordado no curso? 
ANEXOS

ANEXO A - Grade Curricular Do Curso De Cozinheiro - Senac Águas De São Pedro

\begin{tabular}{|c|c|}
\hline $\begin{array}{l}\text { Conteúdo programático do curso de } \\
\text { cozinheiro: }\end{array}$ & Carga Horária \\
\hline \multicolumn{2}{|l|}{$1^{a}$ Fase: Ajudante de Cozinha } \\
\hline - Atividades de Ambientação & 21 \\
\hline - Tecnologias Especificas de Cozinha & 63 \\
\hline - Prática em Serviço de Legumeria & 144 \\
\hline - Prática de Açougue & 144 \\
\hline SUBTOTAL & 372 \\
\hline \multicolumn{2}{|l|}{$2^{\mathrm{a}}$ Fase: Cozinheiro (Iniciação) } \\
\hline - Tecnologias Especificas de Cozinha & 64 \\
\hline - Prática em Serviço de Garde-Manger & 72 \\
\hline - Prática em Serviço de Cozinha & 72 \\
\hline - Prática em Serviço de Confeitaria & 144 \\
\hline SUBTOTAL & 352 \\
\hline \multicolumn{2}{|l|}{$3^{\text {a }}$ Fase: Cozinheiro } \\
\hline - Tecnologias Específicas de Cozinha & 44 \\
\hline - Prática em Serviço de Cozinha & 252 \\
\hline - Visita Técnica & 24 \\
\hline SUBTOTAL & 320 \\
\hline TOTAL DA CARGA HORÁRIA & 1044 \\
\hline
\end{tabular}


ANEXO B - Planos De Ensino Reformulados.

* Os itens em negrito foram reformulados depois do curso.

\section{CONTEÚDO PROGRAMÁTICO \\ Curso De Cozinheiro $1^{\text {a }}$ Fase Tecnologias Especificas De Cozinha}

\section{Setor: Legumeria}

\section{$1^{a}$ AULA}

- Conteúdo

- história da gastronomia

- classificação de legumes

- importância da higienização de hortifruti

- educação ambiental no ambiente gastronômico

- identificação dos vegetais, legumes e frutas;

- identificação de cortes de vegetais, legumes e frutas

- uso

\section{- Modalidade}

- Aula demonstrativa prática

- Local

- Departamento de legumeria da cozinha central

2a AULA

- Conteúdo

- identificação dos produtos

- classificação de legumes e frutas

- classificação dos variados tipos de cortes de legumes e frutas

- aproveitamento de aparas

- reaproveitamento de matéria-prima visando o não desperdício

- usos e como comprar

- Modalidade

- aula demonstrativa prática

- Local

- departamento de legumeria da cozinha central

$3^{\text {a }}$ AULA (02 dias)

$1^{\circ}$ Dia - Conteúdo

- Fator de rendimento e correção

- bases de cozinha

- fundos e guarnições aromáticas,

- ligações, espessantes, melhoradores e embelezadores de sabor

- guarnições aromáticas

- fundo claro 
- aves e peixes (fundo dourado)

- fundo escuro carne

- uso moderado de recursos naturais

\section{- Modalidade}

- aula demonstrativa prática

- Local

- laboratório da cozinha pedagógica

$4^{\mathrm{a}}$ AULA (02 dias)

$2^{\circ}$ Dia- Conteúdo

- molhos básicos

- qualidade na produção de molhos

- bechamel

- velote de frango e peixe

- molho espanhol e demi-glace

- molho de tomate

- molho holandês

- maionese

- vinagrete

- molho de tomate

- derivados

- redução de lixo e aumento de receita

- Modalidade

- aula demonstrativa prática

- Local

- laboratório da cozinha pedagógica

$5^{\text {a }}$ AULA (02 dias)

$1^{\circ}$ Dia

- Conteúdo

- métodos de cocção: tipos, características, utilização

- calor seco

- calor úmido

- calor misto

- métodos de cocção contemporâneos

- auxiliares de cocção

- higiene na manipulação de alimentos

\section{- Modalidade}

- aula teórica 
- sala de aula convencional

$5^{a}$ AULA (02 dias)

$2^{\circ}$ Dia

- Conteúdo

- métodos de cocção: assar, saltear, grelhar, escalfar, brasear, fritar, vapor

- montagem de empratados

- uso racional de energia elétrica

- Modalidade

- aula demonstrativa prática

- Local

- laboratório da cozinha pedagógica

$6^{\text {a }}$ AULA

- Conteúdo

- sopas cremosas, consommês, sopa com caldo (canja, minestrone)

- uso moderado de produtos químicos

- Modalidade

- aula demonstrativa prática

- Local

- laboratório da cozinha pedagógica

$7^{\mathrm{a}}$ AULA

- Conteúdo

- identificação de produtos

- compras, recebimento e armazenagem

- gastos (logística)

- visita técnica pelo almoxarifado

- separação adequada do lixo

- Modalidade

- aula demonstrativa prática

- Local

- laboratório da cozinha pedagógica

\section{$8^{\mathrm{a}}$ AULA}


- Avaliação (trabalho escrito em grupo conforme definição do professor)

- Modalidade

- teórica

- Local

- sala de aula tradicional

\section{Setor: Acougue}

$1^{a}$ AULA

- Conteúdo

- definição de cortes de aves

- inicio da aula demonstração dos cortes

- cuidados operacionais: higiene e manipulação de aves (abatimento desordenado da matéria prima com relação ao meio ambiente)

- desossar e limpar e cortes de frangos, perdizes, codorna, pato

- técnica de conservação das aves

- Modalidade

- aula demonstrativa prática

- Local

- laboratório da cozinha pedagógica

$2^{\mathrm{a}}$ AULA (02 dias)

$1^{\circ}$ Dia

- Conteúdo

- definição de cortes de carnes

- limpeza, dessossa do quarto traseiro, bovino, suíno, ovino, ovelha

- cortes especificos das peças dos animais: identificação

- reaproveitamento de alimentos e redução de resíduos: carnes e ossos

- Modalidade

- aula demonstrativa prática

- Local

- departamento de açougue da cozinha pedagógica

\section{$3^{\text {a }}$ AULA}

\section{$2^{\circ}$ Dia}


- Conteúdo

- continuação dos cortes de carne, limpeza e padronização das peças

- filé mignon, contra-filé, picanha, carré

- apresentar aos alunos as viabilidades e inviabilidades quanto ao serviços de bufê e à la carte: atentando-se para o desperdício de alimentos

- organização na manipulação e armazenamento adequado dos alimentos que não são utilizados na cozinha quente e são rearmazenados na câmara fria

- Modalidade

- aula demonstrativa prática

- Local

- laboratório da cozinha pedagógica

$4^{\text {a }}$ AULA (02 dias)

$1^{\circ}$ Dia

Conteúdo

- definição de cortes de peixes

- definição de frutos do mar

- limpeza de peixes, moluscos e frutos do mar

- conservação

- fornecedores: conscientização do tipo de embalagem dos produtos

- armazenamento adequado dos alimentos: quanto a data de validade, embalagem, temperatura e higiene do local

- Modalidade

- aula demonstrativa prática

- Local

- laboratório da cozinha pedagógica

$5^{\mathrm{a}}$ AULA

$2^{\circ}$ Dia

- Conteúdo

- tipos de cortes

- conservação: tempo e manipulação quanto a tabela de vida útil que os alimentos podem permanecer fora da câmara fria

- uso moderado de produtos químicos 
- encaminhamento do lixo

- Modalidade

- aula demonstrativa prática

- Local

- laboratório da cozinha pedagógica

\section{$6^{\text {a }}$ AULA}

- Conteúdo

- avaliação: trabalho escrito sobre carnes, aves, frutos do mar

- Modalidade

- aula teórica

- Local

- sala de aula tradicional

\section{Setor: Garde-Manger}

$1^{\text {a }}$ AULA

- Conteúdo

- introdução a garde-manger:

- definição e funcionamento do setor quanto as responsabilidades e atribuições

- histórico do setor de garde-manger

- organização física e de funcionamento do setor

- reflexão sobre o tema: meio ambiente

\section{- Modalidade}

- aula expositiva

- Local

- sala de aula tradicional

- departamento de garde-manger da cozinha central

$2^{\text {a }}$ AULA

\section{- Conteúdo}

- serviços: bufê e entrada à la carte: montagem de espelhos e pratos para saladas à la carte - cuidados, vantagens e desvantagens quanto aos 
dois tipos de serviços no que diz respeito ao desperdício de alimentos e o reaproveitamento dos mesmos

- molhos emulsionados, contemporâneos e alternativos: derivados de maionese e do vinagrete, molhos alternativos (frutas, chutney, etc)

- molhos especiais

- molhos reduzidos

- molhos líquidos

- molhos cremosos

- couli

- decorações e combinações

- pratos para recepção: hours d'ouvre frios e quentes e canapés

- apresentação de pratos

- uso moderado de produtos químicos

\section{- Modalidade}

- aula demonstrativa prática

- Local

- departamento de garde-manger da cozinha pedagógica

$3^{\text {a }}$ AULA (02 dias)

$1^{\circ}$ Dia

- Conteúdo

- salgas e curas

- produtos orgânicos

- defumação

- galantine

- terrine

- ballontines: viabilidade e inviabilidade deste tipo de preparação quanto ao tempo de cozimento e o uso de gás

- patê em crôute

- preparo de massa, recheios, técnica de cocção

- aspic, mousse salgadas e mouseline: $o$ uso de produtos naturais

- higienização da cozinha

- alerta a contaminação cruzada dos alimentos

\section{- Modalidade}

- aula demonstrativa prática

- Local

- laboratório da cozinha pedagógica

\section{$4^{\mathrm{a}}$ AULA}

\section{$2^{\circ}$ Dia}




\section{Conteúdo}

- continuação: patê em crôute, corte das galantines, aspics e terrines

- decorações e combinações em espelhos e travessas

- higiene na manipulação dos alimentos

- Modalidade

- aula demonstrativa prática

- Local

- laboratório da cozinha pedagógica

\section{$5^{\mathrm{a}}$ AULA}

\section{- Conteúdo}

- queijos: utilização e cortes

- histórico

- origem

- fabricação e tipos

- conservação

- laticínios: leite e seus derivados

- produtos de charcutaria: tipos e cortes

- inclusão social

- Modalidade

- aula demonstrativa prática

- Local

- laboratório da cozinha pedagógica

\section{$6^{\mathbf{a}}$ AULA}

\section{- Conteúdo}

- avaliação: pesquisa sobre o setor de garde-manger

\section{- Modalidade}

- aula teórica

- Local

- sala de aula tradicional

- laboratório de informática

- biblioteca

\section{Setor: Confeitaria}

\section{$\mathbf{1}^{\mathrm{a}}$ AULA}


- Conteúdo

- bases de confeitaria

- meio ambiente no setor de trabalho

- Modalidade

- aula expositiva

- Local

- sala de aula tradicional

- departamento de confeitaria da cozinha central

$2^{a}$ AULA

- Conteúdo

Massas Básicas - Parte I

- preparação de pão-de-ló (variações)

- biscuit joconde

- massa folhada

- patê brisée: doce e salgada

- patê sucrée

- daquoise

- produtos orgânicos (conceito)

- preparação de crepes

- biscoito $1,2,3$,

- patê choux

- Modalidade

- aula demonstrativa prática

- Local

- departamento de confeitaria da cozinha pedagógica

$3^{\text {a }}$ AULA

- Conteúdo

Massas Básicas - Parte II

- crepe ou panqueca

- massa strudel

- massa choux

- tuiles

- produtos orgânicos (utilização) 
- Modalidade

- aula demonstrativa prática

- Local

- laboratório de confeitaria da cozinha pedagógica

\section{$4^{\text {a }}$ AULA}

\section{- Conteúdo}

Massas Básicas - Parte III

- massa folhada

- massa folhada de chocolate

- produtos orgânicos (debate)

- preparação de doces

- preparação de tortas

- preparação de doces em caldas

- preparação de recheios

- preparação de caldas

- chocolates

- decoração

- montagem de bufê: armazenamento e cuidados quanto ao desperdício de alimentos

\section{- Modalidade}

- aula demonstrativa prática

- Local

- laboratório de confeitaria da cozinha pedagógica

\section{$5^{\mathbf{a}}$ AULA}

\section{- Conteúdo}

\section{Cremes Básicos}

- creme patissiére

- creme inglês (anglaise)

- creme chantilly

- creme zabaglione

- creme manteiga

- higiene na manipulação de alimentos

\section{- Modalidade}

- aula demonstrativa prática 
- Local

- laboratório de confeitaria da cozinha pedagógica

$6^{\text {a }}$ AULA

- Conteúdo

Montagem de bolos e tortas

usando massas básicas e cremes básicos

- Modalidade

- aula demonstrativa prática

- Local

- laboratório de confeitaria da cozinha pedagógica

$7^{\text {a }}$ AULA

- Conteúdo

Gelatinas

- mousse x creme bávaro

- sorbet $\mathrm{x}$ sorvete

- cuidados na utilização de descartáveis

- Modalidade

- aula demonstrativa prática

- Local

- laboratório de confeitaria da cozinha pedagógica

$8^{a}$ AULA

- Conteúdo

Merengues (variações)

- suíço 
- francês

- italiano

- diversificação na produção e utilização de materiais adequados para o meio ambiente

- Modalidade

- aula demonstrativa prática

- Local

- laboratório de confeitaria da cozinha pedagógica

9a AULA

- Conteúdo

Apresentação de sobremesas

- empratadas

- vinhos para preparação de sobremesas

- encaminhamento do lixo: seletividade e cuidados

- Modalidade

- aula demonstrativa prática

- Local

- laboratório de confeitaria da cozinha pedagógica

\section{$10^{\mathrm{a}}$ AULA}

- Conteúdo

\section{Decoração em chocolate}

- temperagem

- arabescos

- chocolate plástico e outros

- reaproveitamento adequado dos alimentos

- Modalidade

- aula demonstrativa prática

- Local

- laboratório de confeitaria da cozinha pedagógica 
$11^{\mathrm{a}}$ AULA

- Conteúdo

Trabalhos em açúcar

- pasta americana

- escultura em açúcar

- segurança no setor de trabalho da confeitaria

- Modalidade

- aula demonstrativa prática

- Local

- laboratório de confeitaria da cozinha pedagógica

$12^{\mathrm{a}}$ AULA

- Conteúdo

Panificação

- tipos de fermentação

- tipos de farinha

- reflexão sobre a degradação e poluição do meio ambiente quanto ao método de cocção no setor de panificação

- Modalidade

- aula demonstrativa prática

- Local

- laboratório de confeitaria da cozinha pedagógica

$13^{\mathrm{a}}$ AULA

- Conteúdo

- avaliação: pesquisa sobre tipos de confeitaria

- sugestões:

1. confeitaria brasileira: Bahia, Minas, São Paulo, Santa Catarina

2. confeitaria internacional: França, Itália, Paises Árabes, Europa

- Modalidade

- aula teórica

- Local

- sala de aula tradicional

- laboratório de informática 
- biblioteca

\section{Setor: Cozinha Quente}

\section{$\mathbf{1}^{\mathrm{a}}$ AULA}

\section{- Conteúdo}

- meio ambiente com inserção na produção culinária

- higiene alimentar, ambiental e pessoal na cozinha

- documentação de cozinha: sua importância e utilização

- serviço à la carte (cardápio do Grande Hotel)

- orientação do trabalho de conclusão de curso

\section{- Modalidade}

- aula expositiva

- Local

- sala de aula tradicional

\section{$2^{a}$ AULA}

\section{- Conteúdo}

- visão sistêmica de tipologias de restaurantes

- elaboração de cardápio: estrutura

- desperdício de alimentos e reaproveitamento adequado

- elaboração de cardápio e suas fases

- planejamento

- implantação

- adequação à estrutura da cozinha, do restaurante e da clientela

- exercícios de ficha técnica

\section{- Modalidade}

- aula expositiva

- Local

- sala de aula tradicional

$3^{\text {a }}$ AULA (06 dias)

$1^{\circ}$ Dia

\section{- Conteúdo}

- serviço à la carte - cardápio do Grande Hotel

- técnicas do preparo de pratos

- elaboração de ficha técnica

- orientação sobre o uso adequado de produtos quimicos 
- Modalidade

- aula demonstrativa prática

- Local

- laboratório da cozinha pedagógica

$4^{\text {a }}$ AULA

$2^{\circ}$ Dia

Conteúdo

- serviço à la carte - cardápio do Grande Hotel

- técnicas do preparo de pratos

- elaboração de ficha técnica

- diminuição de custos voltados para a preservação do meio natural

\section{- Modalidade}

- aula prática (os alunos vão exercitar)

- Local

- laboratório da cozinha pedagógica

\section{5a AUA}

$3^{\circ}$ Dia

- Conteúdo

- serviço à la carte - cardápio do Grande Hotel

- técnicas do preparo de pratos

- elaboração de ficha técnica

- desperdício, reciclagem e consumismo

- Modalidade

- aula prática (os alunos vão exercitar)

- Local

- laboratório da cozinha pedagógica

$6^{\text {a AULA }}$

$4^{\circ}$ Dia

- Conteúdo

- serviço à la carte - cardápio do Grande Hotel 
- técnicas do preparo de pratos

- elaboração de ficha técnica

- redução de gastos operacionais

\section{- Modalidade}

- aula prática (os alunos vão exercitar)

- Local

- laboratório da cozinha pedagógica

\section{$7^{\text {a AULA }}$}

$5^{0}$ Dia

- Conteúdo

- serviço à la carte - cardápio do Grande Hotel

- técnicas do preparo de pratos

- elaboração de ficha técnica

- redução de lixo

\section{- Modalidade}

- aula prática (os alunos vão exercitar)

- Local

- laboratório da cozinha pedagógica

\section{$8^{\text {a }}$ AULA}

\section{$6^{0}$ Dia}

- Conteúdo

- serviço à la carte - cardápio do Grande Hotel

- técnicas do preparo de pratos

- elaboração de ficha técnica

- debate: vantagens e desvantagens comerciais e ambientais com relação a praticidade, custo e desperdício

- reflexão sobre as tendências atuais no mercado de trabalho

\section{- Modalidade}

- aula prática (os alunos vão exercitar) 
- laboratório da cozinha pedagógica

9a AULA

- Conteúdo

- Avaliação trabalho de conclusão de curso

- Entrega do trabalho

- Modalidade

- Apresentação oral 


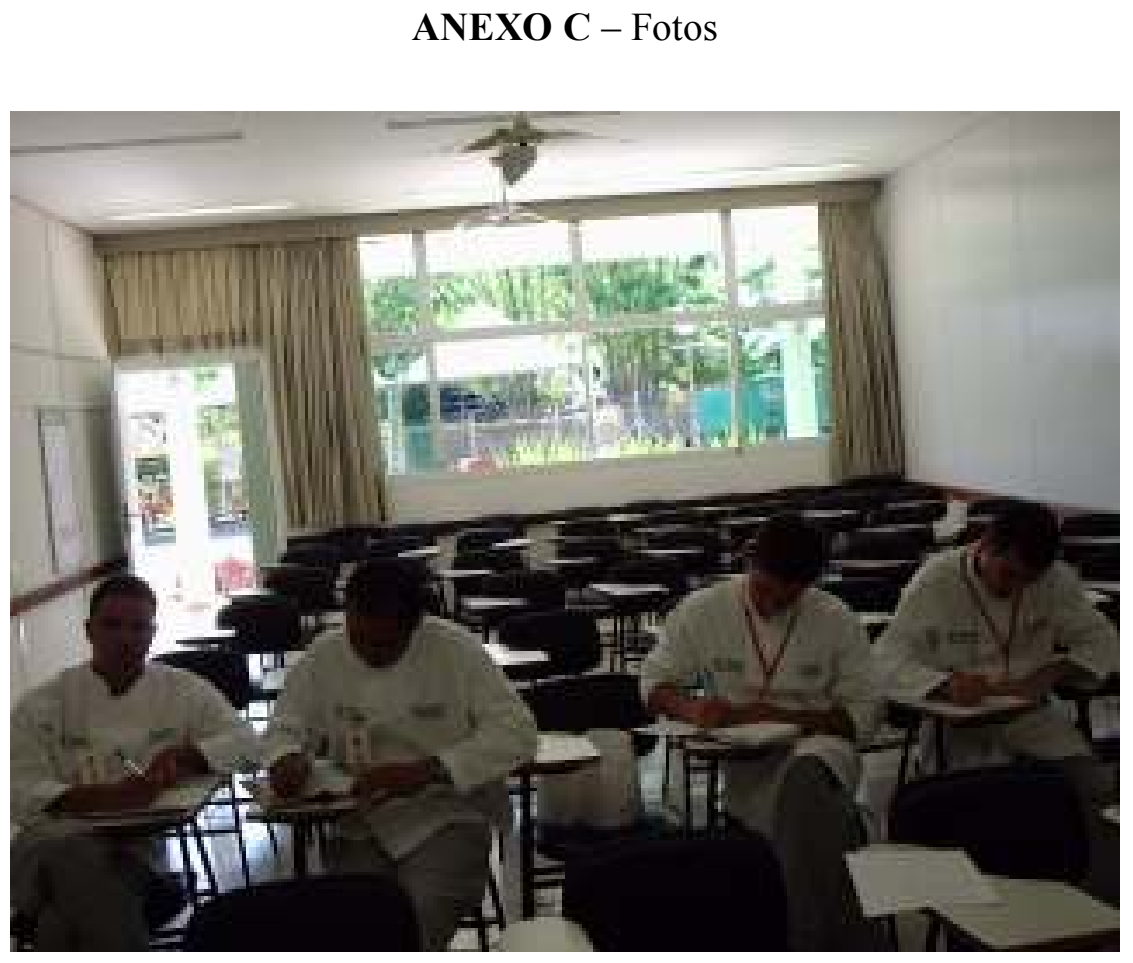

Foto: MANFRINATO, 2005

Figura 6 - Questionário de investigação da inserção do tema ambiental no curso de gastronomia aplicado aos professores

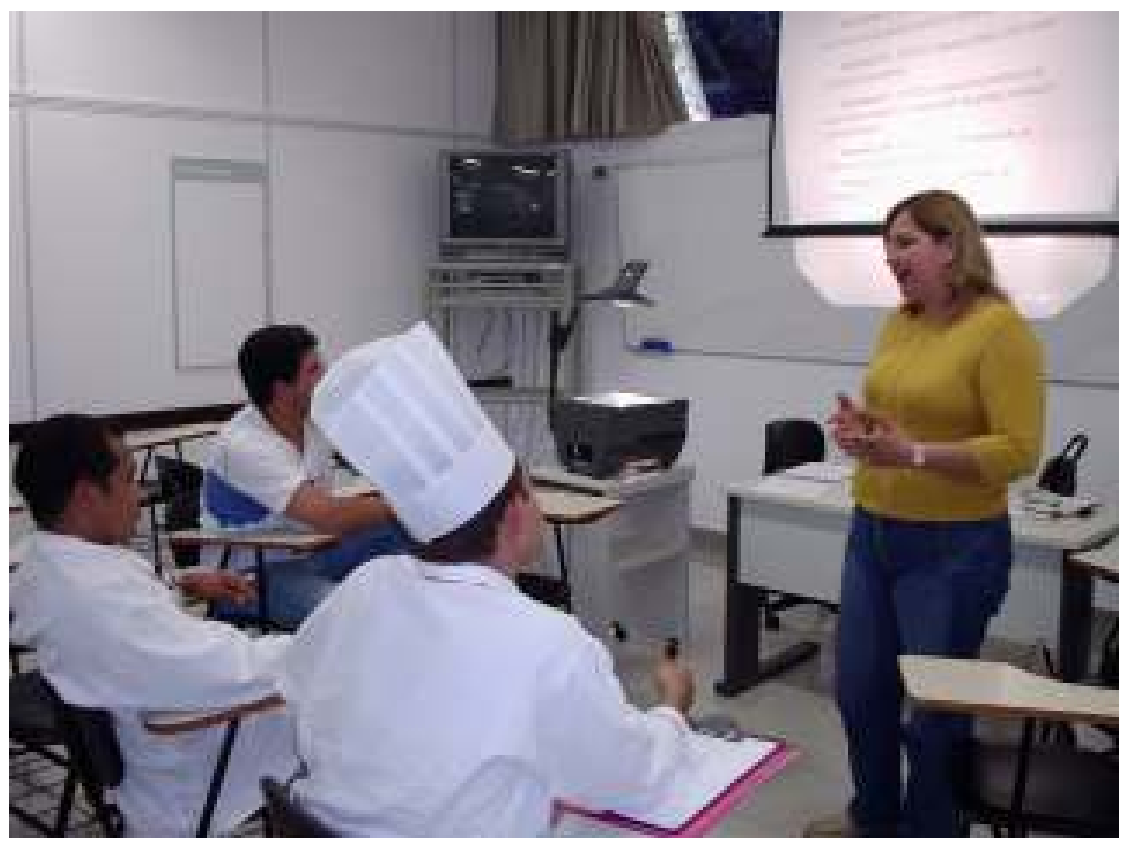

Foto: MANFRINATO, 2005

Figura 7 - Apresentação dos resultados do questionário aplicado aos professores e a coordenação sobre a inserção do tema ambiental no curso de gastronomia 


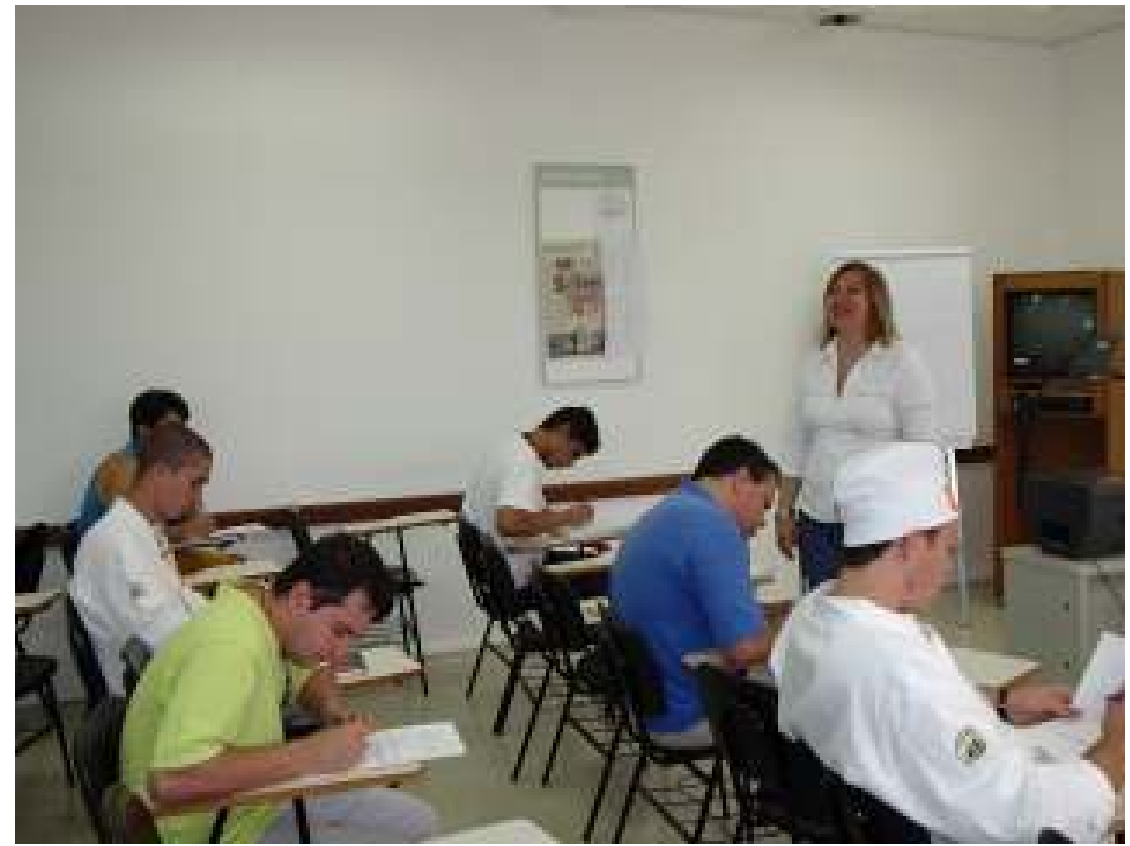

Foto: MANFRINATO, 2005

Figura 8 - Questionário de investigação da inserção do tema ambiental no curso de gastronomia aplicado aos alunos

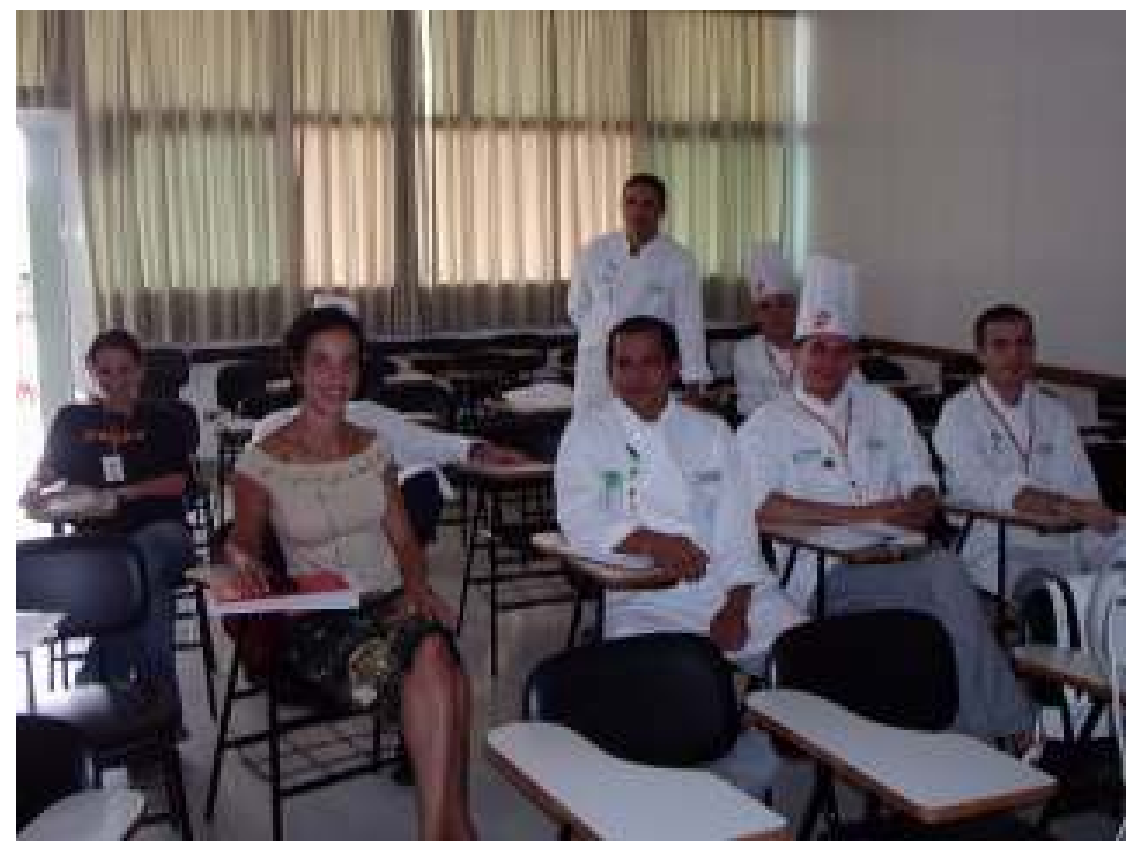

Foto: MANFRINATO, 2005

Figura 9 - Workshop desenvolvido junto dos professores do curso de gastronomia 


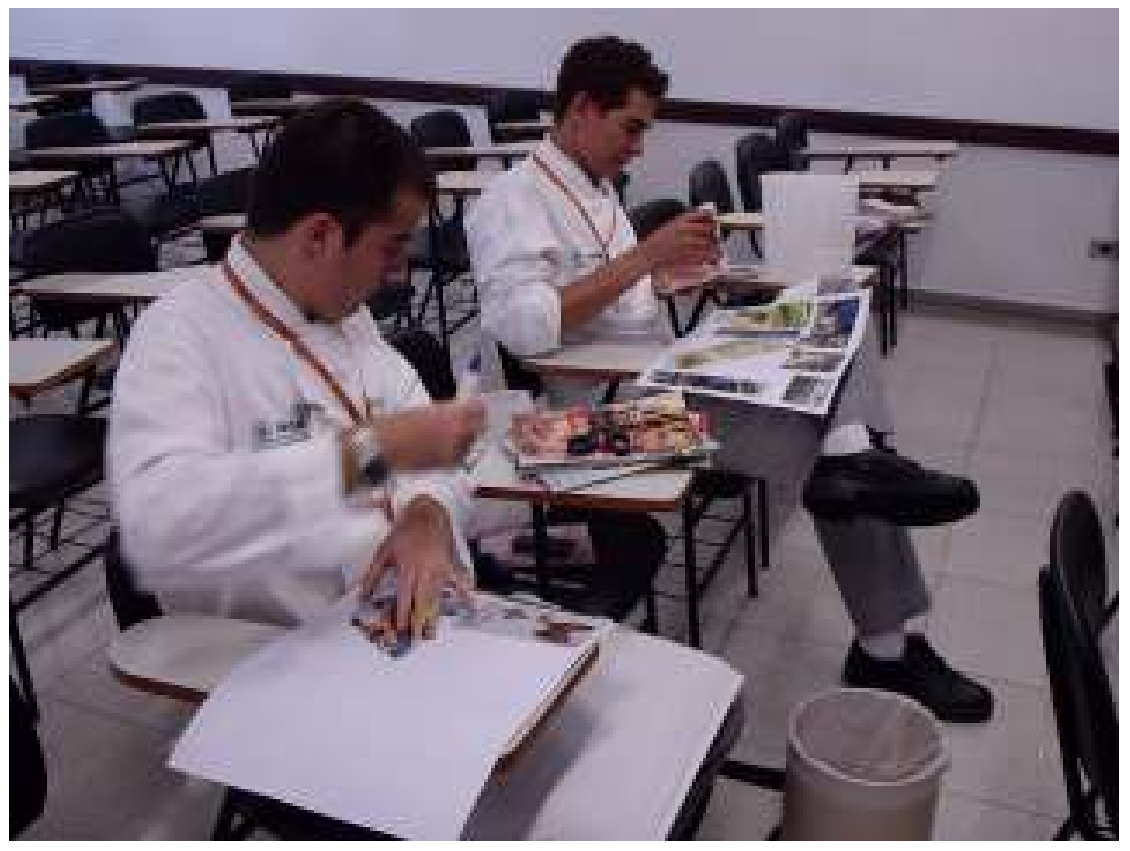

Foto: MANFRINATO, 2005

Figura 10 - Elaboração de painel sobre o conceito de meio ambiente no curso de gastronomia

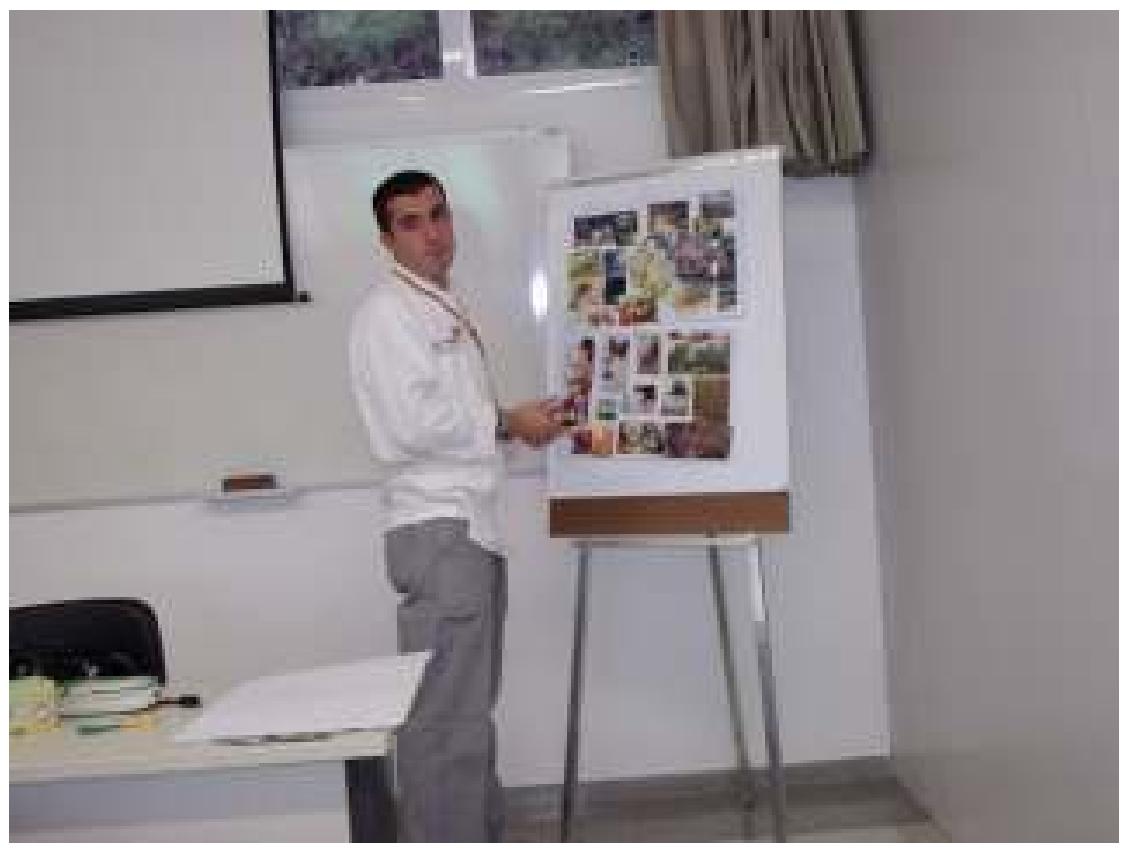

Foto: MANFRINATO, 2005

Figura 11 - Apresentação de trabalhos durante o workshop 


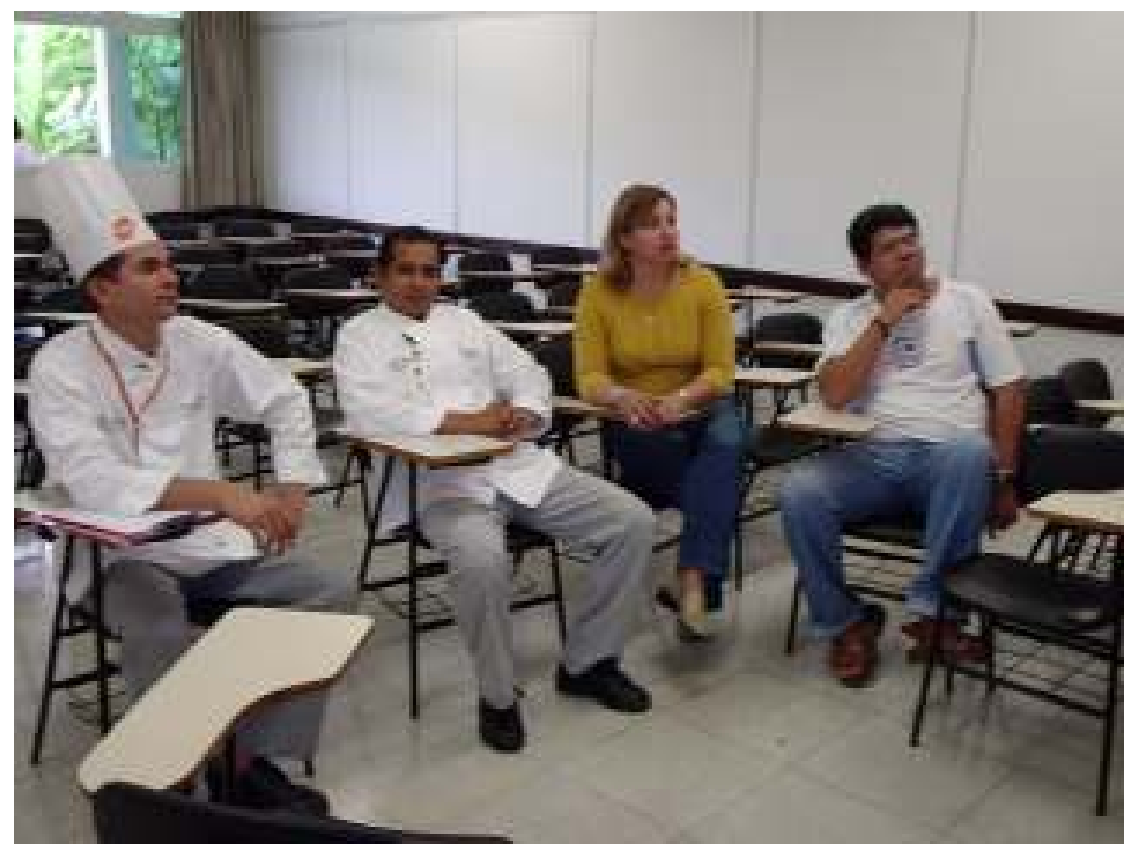

Foto: MANFRINATO, 2005

Figura 12 - Apresentação de trabalhos executados durante o workshop

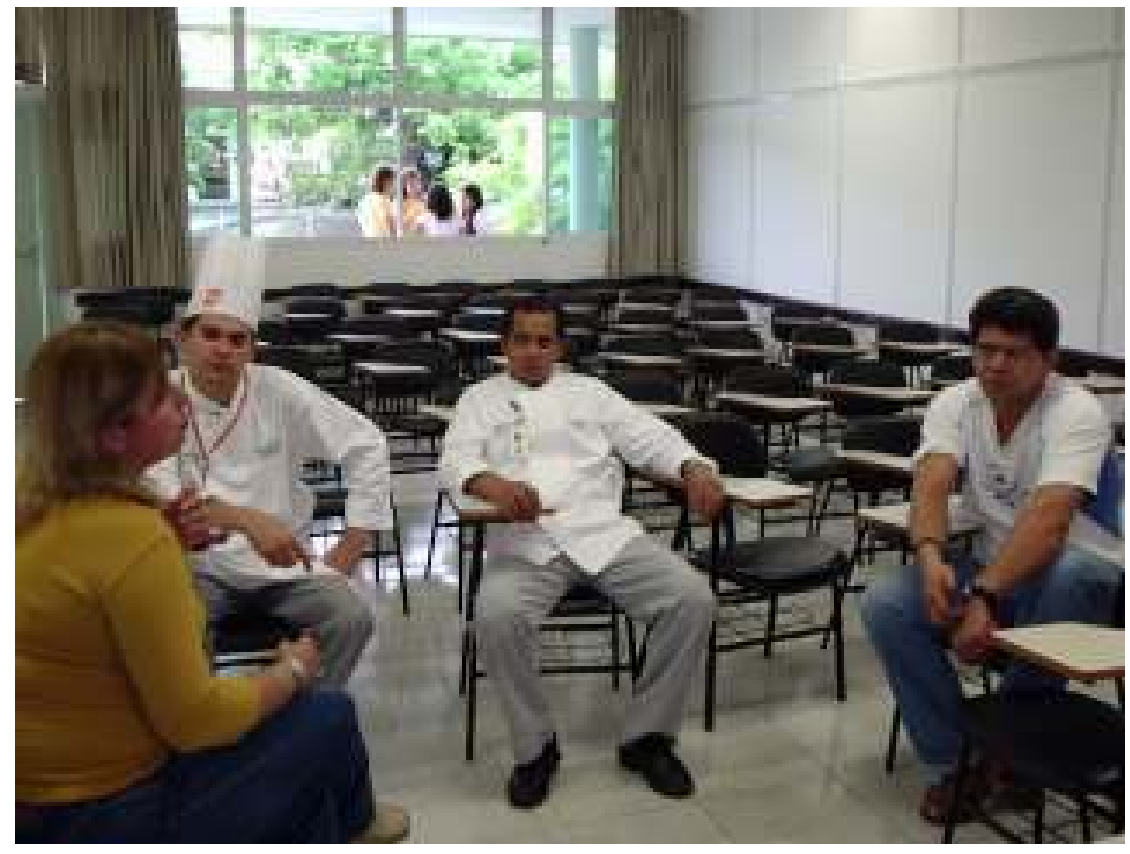

Foto: MANFRINATO, 2005

Figura 13 - Debate sobre os temas de educação ambiental 


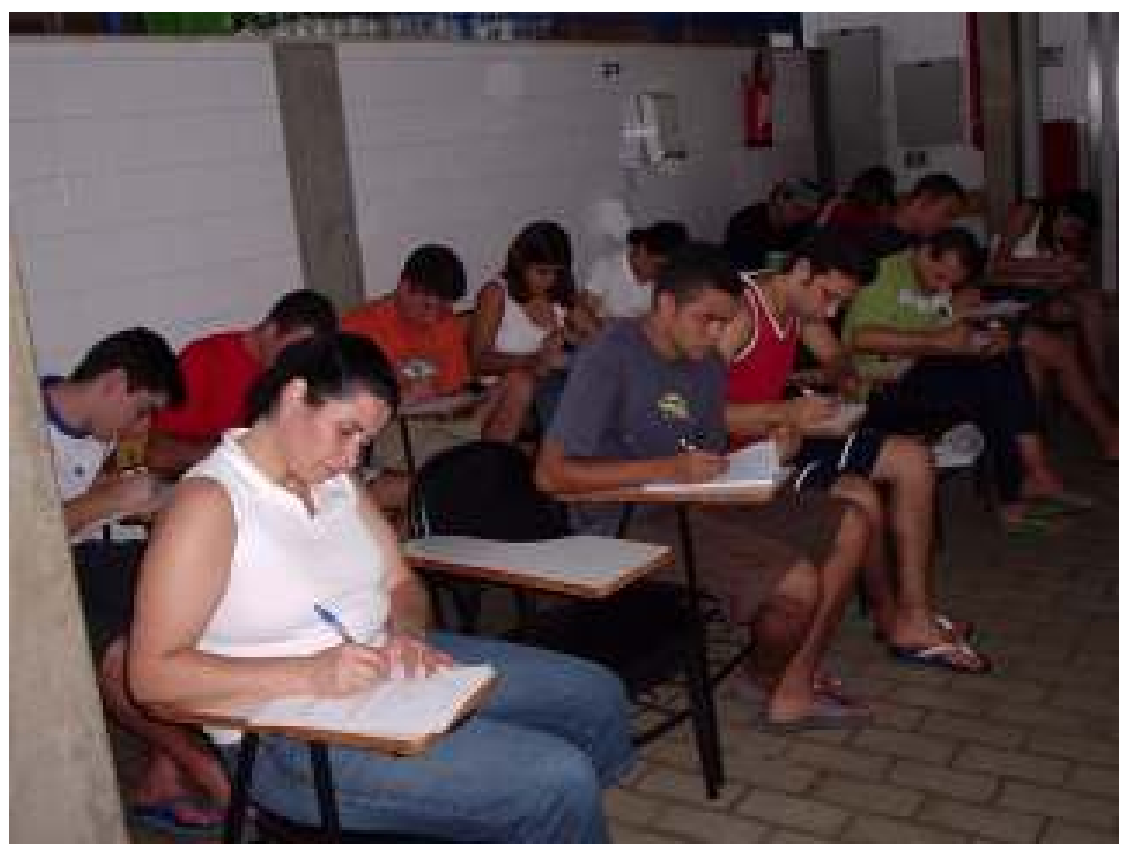

Foto: MANFRINATO, 2005

Figura 14 - Coleta de resultados da inserção do tema junto dos alunos no curso de gastronomia

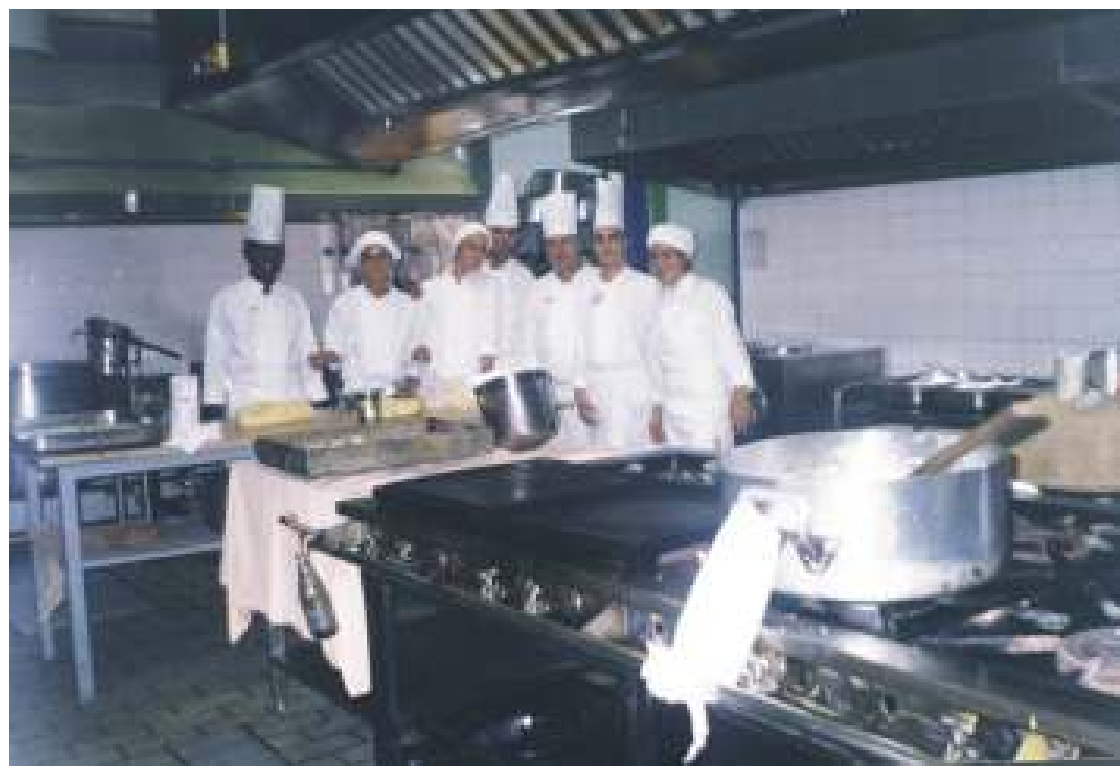

Foto: MANFRINATO, 2005

Figura 15 - Aula ministrada pelos professores no laboratório de gastronomia 